\author{
Universidade de São Paulo \\ Instituto de Astronomia, Geofísica e Ciências Atmosféricas \\ Departamento de Astronomia
}

Fernando de Sousa Mello

\title{
Habitabilidade na Via-Láctea em Várias Escalas
}

São Paulo 

Fernando de Sousa Mello

\section{Habitabilidade na Via-Láctea em Várias Escalas}

Tese apresentada ao Departamento de Astronomia do Instituto de Astronomia, Geofísica e Ciências Atmosféricas da Universidade de São Paulo como requisito parcial para a obtenção do título de Doutor em Ciências.

Área de Concentração: Astronomia

Orientador: Prof. Dr. Amâncio César Santos Friaça

Versão Corrigida. O original encontra-se disponível na Unidade.

São Paulo 

Para os estranhos jovens sonhadores. 



\section{Agradecimentos}

Muitos contribuíram direta ou indiretamente para a conclusão deste trabalho. O longo alcance dessas contribuições beira o horizonte causal do nosso canto no Universo, mas é preciso delimitar aquelas que me pareceram imprescindíveis ao longo dos anos. Começo agradescendo ao própio Universo, já que este trabalho, eu e você, caro leitor, não estaríamos aqui sem ele. À C.C., por tudo e por todo. À minha família, pelo constante apoio. Ao Amâncio, por me aguentar em minha ausência, distância e ingenuidade. Aos professores e pesquisadores que me educaram e me guiaram por muitos anos. Aos amigos e colegas, somente alguns instantes já significam muito. Às Instituições que me ajudaram. À Capes, pelo apoio financeiro, sob o código de financiamento 001 e ao $\mathrm{CNPq}$, pelo apoio financeiro, sob o projeto $\mathrm{n}^{o}: 140172 / 2015-7$.

Obrigado a todos. 

"We're searching for intelligent life-forms that have also evolved conscious self-awareness. We're searching for intelligent, conscious life-forms that have both the available resources and the need to manipulate raw materials into tools. We're searching for intelligent, conscious, tool-making beings that have developed a language we're capable of understanding. We're searching for intelligent conscious, tool-making, communicative beings that live in social groups (so they can reap the benefits of civilization) and that develop the tools of science and mathematics. We're searching for ourselves . . ."

Stephen Webb em If the Universe Is Teeming with Aliens... WHERE IS EVERYBODY? Seventy-Five Solutions to the Fermi Paradox and the Problem of Extraterrestrial Life.

"Nós voamos através do cosmo preparados para tudo, isto é, a solidão, a luta, a fadiga e a morte. O pudor nos impede de proclamar isto, mas, em certos instantes, julgamo-nos admiráveis. No entanto, olhado com calma, nosso entusiasmo não passa de blefe. Não queremos conquistar o cosmo, queremos apenas levar a Terra às fronteiras dele. Tal planeta será árido como o Saara, outro tão glacial como nossas regiões polares, outro tão luxuriante como a Amazônia. Somos humanitários e cavalheirescos, não queremos escravizar outras raças, queremos apenas transmitir-lhes nossos valores e, em troca, nos apoderarmos de seu patrimônio. Consideramo-nos os Cavalheiros do Santo Contato. É outra mentira. Só nos interessa o homem. Não precisamos de outros mundos. Precisamos de espelhos. Não sabemos o que fazer dos outros mundos. Um único mundo, o nosso mundo, nos é suficiente, mas não o aceitamos como ele é. Procuramos uma imagem ideal do nosso próprio mundo. Saímos à procura de um planeta, de uma civilização superior à nossa, mas desenvolvida na base do protótipo do nosso passado primitivo."

Snaut em Solaris de Stanislaw Lem. 



\section{Resumo}

A Galáxia é muito vasta para inicialmente explorarmos cada ponto detalhadamente na busca por vida. É necessário concentrar nossos esforços e atenção nos locais mais promissores. Além disso, parece não haver muitos modelos que tentem avaliar a habitabilidade de um planeta considerando o sistema como um todo, similarmente aos estudos do sistema Terra. Desse modo, o objetivo deste trabalho é estudar a habitabilidade da Via-Láctea desde a escala planetária até a escala Galáctica para derivar as características melhor associadas à habitabilidade planetária, e as regiões de nossa Galáxia mais promissoras para a procura por vida, jogando alguma luz na relação entre os fatores mais relevantes em cada escala. Os resultados desses estudos orientariam programas de busca por exoplanetas habitáveis na Galáxia. Desenvolvemos um modelo mínimo da co-evolução da geosfera, atmosfera e biosfera de nosso planeta para avaliar a evolução das condições de habitabilidade e estimar o tempo de vida da biosfera terrestre. Aplicamos esse modelo na exploração de alguns limites simples de habitabilidade para possíveis planetas telúricos e no estudo da zona habitável circunstelar (ZHC) em função de parâmetros planetários e estelares. Um modelo de evolução química da Galáxia nos permitiu conectar nosso modelo de habitabilidade à escala Galáctica e obter a densidade de planetas habitáveis em função do raio Galactocêntrico e da idade da Galáxia. Os resultados do nosso modelo básico indicam que a biosfera terrestre provavelmente entrará em colapso em 1,63 Ganos devido ao aumento da temperatura. Planetas terrestres mais massivos e com maior abundância de material radioativo do que a Terra poderiam se manter habitáveis por longos períodos de tempo. A queda nos indicadores de atividade geológica nos planetas telúricos ao longo do tempo seria um fator restritivo adicional da extensão da ZHC em relação às suas estimativas tradicionais. Planetas habitáveis seriam mais facilmente encontrados em torno de estrelas mais 
jovens e mais metálicas. Cerca de $2 \times 10^{8}$ planetas habitáveis existiriam na Via-Láctea atual, $80 \%$ sendo mais velhos do que a Terra, e $\sim 2 / 3$ residindo em raios internos a $7 \mathrm{kpc}$. Nosso trabalho concorda com outros da literatura que indicam que a parte interior da Galáxia seria a região com maior número de mundos habitáveis. Sugerimos que estrelas FGK jovens, mais metálicas e mais ricas em isótopos radioativos, e as regiões internas da Galáxia seriam os locais mais promissores para abrigar planetas habitáveis. Entre os futuros aperfeiçoamentos dos nossos modelos está a melhor integração dos diversos fatores que afetam a habitabilidade de um planeta, como a presença de diferentes gases do efeito estufa, o que poderia influenciar na fronteira exterior da ZHC, e o gradiente de isótopos radioativos na Galáxia, o que afetaria a habitabilidade de planetas telúricos. 


\section{Abstract}

The Galaxy is too vast to initially explore each point in detail in the search for life. It is necessary to concentrate our efforts and attention in the most promising places. In addition, there appear to be not many models attempting to evaluate the habitability of a planet considering the system as a whole, similarly to the studies of the Earth system. Therefore, the goal of this work is to study the habitability of the Milky Way from the planetary scale to the Galactic scale to derive the characteristics most closely associated with planetary habitability, and the regions of our Galaxy most promising for the search for life, shedding some light on the relationship between the most relevant factors in each scale. The results of these studies would guide programs of search for habitable exoplanets in the Galaxy. We have developed a minimal model of co-evolution of the geosphere, atmosphere and biosphere of our planet to evaluate the evolution of habitable conditions and estimate the life span of the terrestrial biosphere. We applied this model in the exploration of some simple limits of habitability for possible telluric planets and in the study of the circumstellar habitable zone $(\mathrm{CHZ})$ as a function of planetary and stellar parameters. A model of chemical evolution of the Galaxy allowed us to connect our habitability model to the Galactic scale and obtain the density of habitable planets as a function of the Galactocentric radius and the age of the Galaxy. The results of our basic model indicate that the terrestrial biosphere will probably collapse at 1.63 Gyr due to the increase in temperature. More massive telluric planets with greater abundance of radioactive material than Earth could remain habitable for long periods of time. The drop in the indicators of geological activity on telluric planets over time would be an additional restrictive factor of the extent of $\mathrm{CHZ}$ in relation to its traditional estimates. Habitable planets would be more easily found around younger, more metallic stars. About $2 \times 10^{8}$ habitable planets would 
exist in the current Milky Way, $80 \%$ being older than Earth, and $\sim 2 / 3$ residing in radii inner than $7 \mathrm{kpc}$. Our work agrees with others in the literature that indicate that the inner Galaxy would be the region with the largest number of habitable worlds. We suggest that young, metal-rich FGK stars that are richer in radioactive isotopes and the inner regions of the Galaxy would be the most promising places to house habitable planets. Among the future improvements of our models are the better integration in a system of the various factors that affect the habitability of a planet, such as the presence of different greenhouse gases, which could influence the outer boundary of the $\mathrm{CHZ}$, and the radioactive isotope gradient in the Galaxy, which would affect the habitability of telluric planets. 


\section{Lista de Figuras}

1.1 Distribuição no plano do disco da Via-Láctea dos exoplanetas confirmados até 20/03/2019 e com distância da estrela até os Sistema Solar determinada no banco de dados de exoplanet.eu (pontos vermelhos - não confundir com as regiões avermelhadas nos braços espirais) sobreposta à uma ilustração no visível da Via-Láctea de NASA/JPL-Caltech/R. Hurt (SSC/Caltech). . . .

2.1 Taxas de produção de energia radioativa do manto. . . . . . . . . . . . . 35

2.2 Volume da crosta continental dado por diferentes trabalho da literatura. . . 38

2.3 Estimativas da quantidade de água no manto por diferentes trabalhos da literatura. . . . . . . . . . . . . . . . . . 40

2.4 Evolução da luminosidade solar ao longo do tempo dada em trabalhos da literatura relacionados ao fim da biosfera. . . . . . . . . . . . . . . . 46

2.5 Comparação do albedo planetário dado por diferentes trabalhos na literatura. 48

2.6 Figuras 1c e 3 de Kasting et al. (1993). . . . . . . . . . . . . . . . . . . 52

2.7 Principais resultados do modelo de evolução térmica do manto terrestre. 62

2.8 Razão de Urey ratio e número de Raileigh para o manto terrestre. . . . . . 63

2.9 Temperatura superficial terrestre ao longo do tempo. . . . . . . . . . . . 66

2.10 Pressão parcial de $\mathrm{CO}_{2}$ na atmosfera terrestre ao longo do tempo. . . . . . 67

2.11 Massa de água nos oceanos e manto e profundidade efetiva dos oceanos em nosso modelo. . . . . . . . . . . . . . . . . . . . . 70

2.12 Comparação dos resultados de diferentes modelos da literatura quanto ao tempo de vida da biosfera. . . . . . . . . . . . . . . . . .

3.1 Figura 11a de Kasting et al. (1993). . . . . . . . . . . . . . . . . 78 
3.2 Comparação do albedo planetário dado por diferentes trabalhos na literatura. 79

3.3 comparação da relação massa-raio para planetas rochosos na literatura com objetos do Sistema Solar. . . . . . . . . . . . . . . . . 80

3.4 Resultados principais da variação da massa planetária. . . . . . . . . . . 83

3.5 Variação da massa planetária. . . . . . . . . . . . . . . . . . 85

3.6 Variação da quantidade de água no manto. . . . . . . . . . . . . . . . 86

3.7 Resultados principais da variação da abundância de material radioativo no

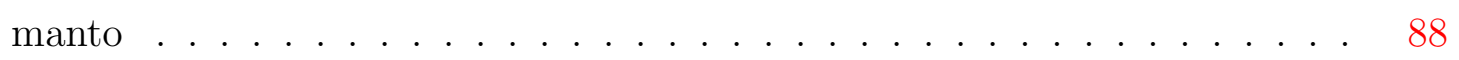

3.8 Variação da abundância de material radioativo no manto . . . . . . . . . . 89

4.1 Comparação de resultados de trabalhos da literatura para os limites da ZHC para o Sistema Solar atual. . . . . . . . . . . . . . . . . . 94

4.2 Comparação dos resultados de diferentes trabalhos da literatura para os limites da ZHC para um planeta semelhante à Terra. . . . . . . . . . . . . 95

4.3 ZHC para um planeta de 1,0 $\mathrm{M}_{\oplus}$ no Sistema Solar ao longo do tempo. . 97

4.4 ZHC para planetas de diferentes massas no Sistema Solar ao longo do tempo. 98

4.5 ZHC para um planeta de 1,0 $\mathrm{M}_{\oplus}$ para estrelas de diferentes massas ao longo do tempo. . . . . . . . . . . . . . . . . . . 100

4.6 Largura da ZHC em ua para diferentes massas planetárias e estelares ao longo do tempo. . . . . . . . . . . . . . . . . . . 103

4.7 Largura da ZHC em ua ponderada pela massa planetária para diferentes massas planetárias e estelares ao longo do tempo. . . . . . . . . . . . . . . 104

4.8 Ajuste de equação aos dados de largura ponderada da ZHC apresentados na Figura 4.7. . . . . . . . . . . . . . . . . . . 105

5.1 Figura 4 de Wang e Fischer (2015) retratando a taxa de ocorrência relativa de planetas de diferentes raios. . . . . . . . . . . . . . . . . . 108

5.2 Ajuste da equação $f_{t}=a \times M_{*}^{b} \times 10^{c[\mathrm{Fe} / \mathrm{H}]}$ às estimativas da fração de estrelas FGK com planetas telúricos. . . . . . . . . . . . . . . . . . . . . . 110

5.3 Fração das estrelas com planetas de certo tipo. . . . . . . . . . . . . . . . . 110

5.4 Alguns resultados do modelo de evolução química do disco da Galáxia. . 118

5.5 Comparação do gradiente radial de metalicidade na Via-Láctea em nosso modelo com a literatura. . . . . . . . . . . . . . . . . . . 119 
5.6 Densidade de planetas telúricos na ZHC de estrelas FGK que não fazem parte de sistemas múltiplos. . . . . . . . . . . . . . . . . . . . . . 123

5.7 Taxa de formação, número de planetas e número cumulativo de planetas. 126

5.8 Fração do total de planetas habitáveis em anéis do disco da Galáxia. . . . . 127

5.9 Distribuição de idade de planetas. . . . . . . . . . . . . . . . . . . . . . . . 129

5.10 Densidade de planetas telúricos habitáveis por $p c^{2}$ no disco da Galáxia . 131

5.11 Ilustração do gradiente radial de densidade de planetas telúricos habitáveis na Galáxia hoje. . . . . . . . . . . . . . . . . . . . . . 132 



\section{Lista de Tabelas}

2.1 Parâmetros da equação 2.2 usando dados de Arevalo Jr et al. (2009). .. 34

2.2 Parâmetros e constantes do modelo de evolução térmica e de trocas gasosas. 43

2.3 Parâmetros e constantes do modelo de intemperismo e de biosfera. . . . . . 56

2.4 Comparação de resultados de nosso modelo com dados da literatura para o tempo atual. . . . . . . . . . . . . . . . . . 61

5.1 Comparação de resultados do modelo de evolução química com dados da literatura. . . . . . . . . . . . . . . . . . . 117 



\section{Sumário}

1. Introdução . . . . . . . . . . . . . . . . . . . . . . 21

1.1 Influências na Habitabilidade . . . . . . . . . . . . . . . . . . . . . 21

1.2 Motivações . . . . . . . . . . . . . . . . . . . . . . 29

1.3 Estrutura da Tese . . . . . . . . . . . . . . . . 30

2. Habitabilidade da Terra . . . . . . . . . . . . . . . . . . . . 33

2.1 Modelo de Evolução Térmica . . . . . . . . . . . . . . . . . 33

2.1.1 Trocas Gasosas . . . . . . . . . . . . . . . . . . . . 39

2.2 Modelo Atmosférico . . . . . . . . . . . . . . . . . . . . . . 44

2.2.1 Albedo Planetário . . . . . . . . . . . . . . . . . . . . 47

2.2 .2 Perda de Água . . . . . . . . . . . . . . . . . . . . . 49

2.3 Intemperismo e Influência Biológica . . . . . . . . . . . . . . . . . . . 54

2.4 Resolvendo o Modelo . . . . . . . . . . . . . . . . . . . . . . . . . . . 60

2.5 Resultados Parciais e Discussão . . . . . . . . . . . . . . . . . 61

2.5.1 Evolução Térmica . . . . . . . . . . . . . . . . . . . . . 61

2.5.2 Paleoclima......................... 64

2.5.3 Metano e o Problema do Sol Jovem Fraco . . . . . . . . . . . . . . 68

2.5.4 Os Oceanos do Passado . . . . . . . . . . . . . . . . . . . . . . 69

2.5.5 O Futuro da Biosfera . . . . . . . . . . . . . . . . . 71

2.6 Conclusões Parciais . . . . . . . . . . . . . . . . . . . . . . . . . . . . . 75

3. Habitabilidade Planetária . . . . . . . . . . . . . . . . . . . . 77

3.1 Modificações no Modelo . . . . . . . . . . . . . . . . 77

3.2 Variação da Massa Planetária . . . . . . . . . . . . . . . . . . . . 82 
3.3 Variação da Quantidade de Água no Manto . . . . . . . . . . . . . . 86

3.4 Variação da Quantidade de Material Radioativo . . . . . . . . . . . . . 87

3.5 Conclusões Parciais . . . . . . . . . . . . . . . . . . . . . . . 90

4. Habitabilidade Estelar . . . . . . . . . . . . . . . . . . . . . . . . 93

4.1 Comparando Zonas Habitáveis . . . . . . . . . . . . . . . . . . . 93

4.2 Zona Habitável Circunstelar no Tempo e no Espaço . . . . . . . . . . . . . 97

4.3 Largura da Zona Habitável Circunstelar . . . . . . . . . . . . . . . . . . . 101

4.4 Conclusões Parciais . . . . . . . . . . . . . . . . . 105

5. Habitabilidade Galáctica . . . . . . . . . . . . . . . . . 107

5.1 Fração de Estrelas com Planetas Telúricos . . . . . . . . . . . . . . . . 107

5.1 .1 Planetas Gigantes e Habitabilidade . . . . . . . . . . . . . . 111

5.1 .2 Planetas Telúricos na ZHC . . . . . . . . . . . . . . . . 113

5.2 Modelo de Evolução Química da Galáxia . . . . . . . . . . . . . . . . . . 116

5.3 Cálculo da Densidade de Planetas Habitáveis . . . . . . . . . . . . . . . . . 119

5.4 As Regiões Mais Habitáveis na Galáxia . . . . . . . . . . . . . . . . . . 122

5.4 .1 Raios e Tempos . . . . . . . . . . . . . . . . . 122

5.4 .2 Números . . . . . . . . . . . . . . . . . . . . . . . . . . 124

5.4 .3 Idades . . . . . . . . . . . . . . . . . . . . . . 127

5.4 .4 Mapa da Habitabilidade . . . . . . . . . . . . . . . . . . 130

5.5 Conclusões Parciais . . . . . . . . . . . . . . . . . . 132

6. Conclusões . . . . . . . . . . . . . . . . . . . . . . 133

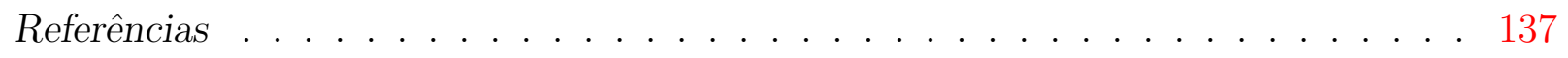

Apêndice $\quad 165$

A. Ajustes do Albedo Planetário . . . . . . . . . . . . . . . . . . 167

A.1 Albedo Planetário para o Sistema Solar . . . . . . . . . . . . . . . 167

A.2 Albedo Planetário para Outras Estrelas . . . . . . . . . . . . . . . 168 
Capítulo 1

\section{Introdução}

O Universo é muito vasto espacialmente e profundo no tempo, tornando muito difícil, com nossos recursos limitados, explorar cada local com a profundidade e a delicadeza necessárias para averiguar a existência de vida. Até mesmo o "simples" objetivo de estudar a vida aqui e agora na Terra já é uma empreitada hercúlea e imensa. O que podemos fazer é concentrar nossos esforços e atenção no que julgamos ser mais promissor, no que esperamos que mais provavelmente retorne um sinal positivo. Para isso, é preciso fazer triagem e apenas definir, ou explicar, o que buscamos já é uma seleção que pode ajudar a delimitar os espaços de busca. Se não temos critérios para escolher ou selecionar, então qualquer direção ou local seria tão bom quanto qualquer outro. Achamos que é possível fazer mais.

\subsection{Influências na Habitabilidade}

Partimos da vida na Terra e tentamos definir as mínimas necessidades ambientais para a existência e manutenção da vida por longas escalas de tempo. Pode ser que a vida na Terra seja incomum, não pela vida em si ser rara, mas pela variedade que temos aqui ter se desenvolvido de maneira incomum. Poderíamos, nesse caso, ter uma visão enviesada da vida, tomando nosso exemplo específico como regra. O caso contrário pode também ser verdade, de que sejamos medíocres e típicos. Difícil dizer qual o real cenário. Como só sabemos da existência de vida na Terra, vamos supor que a vida terrestre seja algo típica em limitações e necessidades, ainda que correndo o risco de algum "terracentrismo".

Nós estamos menos preocupados em definir vida do que em delimitar o espaço de parâmetros ambientais (temperatura, pressão, etc) em que a vida terrestre pode existir 
de maneira estável e prolongada. O segundo depende do primeiro, claro, mas vamos nos focar no segundo. De maneira geral, temos que a vida na Terra é baseada em carbono e em hidrogênio, oxigênio, nitrogênio, fósforo e enxofre (CHONPS), precisando de mais do que apenas hidrogênio e hélio para existir. Esses átomos e uns punhados de outros em pequenas quantidades são arranjamos em grandes moléculas. A vida faz uso extensivo de água líquida, que, assim como as grandes moléculas, só mantém uma forma útil para a vida num estreito intervalo de temperaturas. Só com isso já temos uma ideia de que procurar por vida em estrelas (super quentes e majoritariamente constituídas de hidrogênio e hélio) pode não ser muito eficaz. Procurar em planetas, algo feitos como a Terra - rochosos e metálicos, com água líquida, com temperaturas amenas e com bastante elementos mais pesados do que hidrogênio e hélio - pode ser melhor. Esses elementos pesados são frequentemente tratados aqui como "metais" e a propriedade de possuir mais ou menos metais de "metalicidade"1. Algumas vezes usamos o termo "metal" da maneira típica, mas esperamos que fique claro pelo contexto qual sentido estamos usando.

Na literatura sobre habitabilidade, pode ser algo comum encontrar os termos "vida simples" e "vida complexa". O que separaria vida simples de vida complexa? Seria a diferença entre procarionte e eucarionte? Ou unicelular e multicelular? Vertebrados e invertebrados? Terrestres e aquáticos? Seria o tamanho? Ou seria em relação à alguma necessidade, como depender de uma camada de ozônio para se proteger do UV do Sol? Embora exista alguma intuição quanto ao significado desses termos (vida simples seriam bactérias e micro-organismos em geral e vida complexa seriam seres multicelulares, em especial animais), eles raramente são explicados ou definidos. Certamente que as exigências habitacionais para uma pessoa, uma vaca ou mesmo uma barata seriam bem mais seletas do que para bactérias e arqueias em geral. Nós nos afastamos desse conceito de vida simples ou complexa e pensamos mais em habitabilidade para a biosfera e seguiremos mais voltados para a importância da água líquida em longas escalas de tempo do que a habitabilidade para espécies específicas. Mesmo assim, nosso procedimento é próximo de considerar o que é tido como vida simples, permitindo englobar um maior número de ambientes.

Formas de vida habitam nosso planeta há pelo menos 3,7 $\mathrm{Ga}^{2}$ (Noffke et al., 2013;

\footnotetext{
1 Toda vez que "metalicidade" for mencionada estaremos nos referindo à $[\mathrm{Fe} / \mathrm{H}]$, o logaritmo na base decimal do número de átomos de ferro pelo número de átomos de hidrogênio no mesmo volume em relação à abundância solar, como dado pela equação: $[\mathrm{Fe} / \mathrm{H}]=\log \left[\frac{n(\mathrm{Fe})}{n(\mathrm{H})}\right]-\log \left[\frac{n(\mathrm{Fe} \odot)}{n\left(\mathrm{H}_{\odot}\right)}\right]$ e medido em dex.

${ }^{2}$ Ga é uma contração de giga ano, $10^{9}$ anos.
} 
Ohtomo et al., 2014; Bell et al., 2015), então nosso planeta permaneceu habitável por pelo menos todo esse tempo. O que seria preciso para isso acontecer? Nosso planeta é massivo o suficiente para manter uma atmosfera densa o bastante para permitir a existência de água líquida por impedir a sublimação da água e por aquecer o planeta via efeito estufa. Então a massa do planeta pode ser um fator relevante. Uma rápida olhada no Sistema Solar parece confirmar isso com a Lua e Mercúrio, bem menos massivos do que a Terra, tendo quase nenhuma atmosfera. Marte, em algum ponto intermediário com 0,107 $\mathrm{M}_{\oplus}{ }^{3}$, possui uma tênue atmosfera. E os planetas gigantes possuem massivas atmosferas. No entanto Vênus, que é só ligeiramente menos massivo do que a Terra, tem uma atmosfera muito mais densa do que a terrestre. E Titã, com apenas $0,02 \mathrm{M}_{\oplus}$, mantém uma atmosfera com pressão superficial maior do que a da Terra ao nível do mar. A massa planetária pode ser uma boa aproximação inicial, mas não define tudo.

Sem o efeito estufa a Terra teria uma temperatura superficial média $\sim 30{ }^{\circ} \mathrm{C}$ mais fria. Grande parte desse efeito hoje vem do vapor d'água e do dióxido de carbono. O quanto de $\mathrm{H}_{2} \mathrm{O}$ que existe na atmosfera está relacionado, basicamente, à temperatura (equação de Clausius-Clapeyron) e evaporação da água, já o $\mathrm{CO}_{2}$ vem de processos mais complexos. Mesmo com o crescente aporte antropogênico de $\mathrm{CO}_{2}$ na atmosfera, grande parte tem origem interior, nas dorçais submarinas (principalmente), por metamorfismo de carbonatos e em hotspots. O carbono na atmosfera, na forma de $\mathrm{CO}_{2}$, reage com a água formando ácido carbônico, que por sua vez reage com as rochas, provocando intemperismo químico. O material resultante é levado para os oceanos, decantando e sedimentando na crosta oceânica, que o leva para o manto durante o processo de subducção. No manto, o carbono pode voltar para a atmosfera como $\mathrm{CO}_{2}$ por vias geológicas. Então temos um ciclo de fluxo de carbono envolvendo a atmosfera, a hidrosfera e a geosfera. Conforme mais $\mathrm{CO}_{2}$ é posto na atmosfera por atividade geológica, mais altas as temperaturas ficam, só que as intempéries são promovidas com o aumento da temperatura e levam mais $\mathrm{CO}_{2}$ para fora da atmosfera numa espécie de termostato natural para nosso planeta (Walker et al., 1981). Esse ciclo geológico do carbono ${ }^{4}$ deve ter ajudado a manter a habitabilidade da Terra em longas escalas de tempo e no passado distante. Detalharemos mais o ciclo do carbono no Capítulo seguinte, na seção 2.3.

\footnotetext{
$3 \oplus$ é o símbolo da Terra.

${ }^{4}$ Não confundir com o ciclo biológico do carbono.
} 
Durante o Arqueano ${ }^{5}$, quando o Sol era menos luminoso, nosso planeta recebia bem menos radiação, $\mathrm{CO}_{2}$ e $\mathrm{H}_{2} \mathrm{O}$ sozinhos não poderiam manter nosso planeta tão quente quanto hoje. No entanto, é isso o que as evidências geoquímicas indicam: que as temperaturas não eram glaciais, era quente ou, pelo menos, morno no passado distante terrestre. Discutiremos sobre o problema (ou paradoxo) do Sol jovem fraco (faint young Sun paradox) (Sagan e Mullen, 1972) ao longo dos capítulos seguintes.

Aqui podemos ter alguns indicativos a respeito de habitabilidade planetária. Planetas rochosos mais velhos, e então mais frios internamente e com menor atividade geológica, poderiam ser menos habitáveis, por terem menor capacidade de manter o ciclo do carbono em funcionamento. Planetas rochosos pequenos, com maior relação área por volume, esfriariam mais rápido e também poderiam ter menor capacidade de manter o ciclo do carbono em funcionamento. Em ambos os casos, a tectônica de placas é necessária para manter o ciclo em funcionamento, mas pode ser que não seja completamente necessária para que um planeta seja habitável. Planetas mais massivos e mais jovens do que a Terra podem ser uma boa aposta, mas a literatura parece incerta quanto a se planetas rochosos mais massivos do que uma massa terrestre teriam maior facilidade em manter tectônica de placas (Valencia et al., 2007; O’Neill et al., 2007; Korenaga, 2010; Van Heck e Tackley, 2011; Lenardic e Crowley, 2012). Em termos de massa, o limite inferior pode estar em algo como Marte, com o limite superior talvez não indo muito além de $\sim 5,0 \mathrm{M}_{\oplus}$, por causa da facilidade em acumular voláteis e atmosferas densas em altas massas, facilitando a formação de mundos aquáticos ou "planetas oceanos" (Stapledon, 1937; Abbot e Switzer, 2011) e de mininetunos (Weiss et al., 2018).

Tectônica de placas é o modo mais eficiente para transferência de calor por convecção do interior do planeta, o que facilita a lenta solidificação do núcleo externo e permite a formação de um forte campo magnético (Nimmo, 2002; Driscoll e Bercovici, 2013). Esse forte campo magnético ajuda a proteger o planeta contra a erosão atmosférica das partículas carregadas do vento solar. Tectônica de placas também é tida como um mecanismo estabilizante e que facilita a habitabilidado planetária (Walker et al., 1981; Foley, 2015). Considerando tudo isso e que no Sistema Solar só a Terra possui vida e tectônica de placas em forte atividade, vamos supor que seja um fator relevante para manter a habilidade por longas escalas de tempo.

\footnotetext{
${ }^{5}$ De 4,0 até 2,5 Ga atrás.
} 
O fluxo solar cai com o quadrado da distância, então planetas distantes recebem pouca energia solar e planetas próximos recebem muita energia. Mesmo com mecanismos estabilizantes naturais para lidar com isso, como o ciclo do carbono acima, algumas regiões ao redor do Sol seriam inabitáveis, não permitindo a existência de água líquida por ser muito frio ou muito quente. A região onde é possível manter água líquida em superfícies planetárias de maneira estável é chamada de zona habitável circunstelar (ZHC). Formalizada por Kasting et al. (1984, 1993), o cômputo de seus limites depende do modelo atmosférico utilizado, dos parâmetros escolhidos e dos critérios de habitabilidade adotados.

Em sua forma mais tradicional, o limite interior é determinado pelo momento em que o planeta começa a perder água via fotólise e escape de hidrogênio em curtas escalas geológicas de tempo entrando em um efeito estufa úmido (moist greenhouse) ou quando o planeta se aquece rapidamente, entrando em um efeito estufa desenfreado (runaway greenhouse); o limite exterior é determinado pelo momento em que o $\mathrm{CO}_{2}$ primeiro encontra condições de condensação (e então de formação de nuvens) ou no momento de máximo efeito estufa por $\mathrm{CO}_{2}$. Variações desses limites existem, mas tendem a acompanhar a ideia de "seguir a água", de determinar as condições necessárias para manter água líquida na superfície planetária. Há um grande esmero em aperfeiçoar os modelos atmosféricos de maneira a incluir mais fenômenos e interações. Isso é com razão, pela enorme influência que a atmosfera exerce em determinar a temperatura superficial e na manutenção da vida no planeta. Infelizmente, devido à dificuldade de integrar num único modelo a geosfera, a atmosfera e a biosfera (cada um sistemas já bem complexos em si), não é muito frequente a tentativa de criar, mesmo que em primeiras aproximações, modelos para o sistema Terra de maneira a estudar a habitabilidade do planeta como um todo.

Partindo para uma escala maior, não só o Sol fica mais luminoso com a idade, como toda estrela. Isso tem o efeito de transladar a ZHC cada vez mais para longe da estrela com o passar do tempo. Planetas que antes eram habitáveis podem acabar recebendo energia demais, esquentar demasiadamente e inviabilizar a existência de água líquida em suas superfícies. Paralelamente, um planeta frio pode se ver recebendo energia o suficiente para se tornar habitável. Esse seria o chamado "início gelado" de Kasting et al. (1993). Pode ser que planetas de início gelado nunca sejam habitáveis, havendo alguma necessidade especial de se formarem na ZHC, mas não suporemos isso aqui.

Estrelas de massas diferentes também têm luminosidades, espectros e tempos de estadia 
na sequência principal diferentes, o que pode influenciar na localização ou até na existência da ZHC. Estrelas mais massivas do que o Sol (por exemplo, de tipo A) fundem hidrogênio mais rapidamente, são mais luminosas e tem o espectro deslocado para o azul e para o ultravioleta (UV). A ZHC dessas estrelas é mais distante, mas mais larga do que a do Sistema Solar, infelizmente também é de pouca duração (assim como essas estrelas). Em estrelas menos massivas do que o Sol (por exemplo, de tipo M) ocorre o oposto e a ZHC é bem estreita, próxima da estrela e extremamente longeva (assim como essas estrelas). Estrelas de baixa massa também são formadas muito mais frequentemente do que estrelas mais massivas. Por conta disso, elas têm potencial para serem bons alvos para concentrarmos nossa atenção. No entanto, há complicações. Com uma ZHC tão perto da estrela rapidamente os planetas habitáveis entram em rotação síncrona via efeitos de maré gravitacional, mantendo sempre a mesma face voltada para a estrela. Isso reduz bastante o período de rotação do planeta e, potencialmente, sua habitabilidade, potencialmente calcinando um hemisfério e congelando o outro, mas também porque um período de rotação curto parece estar ligado à possibilidade de manutenção de um campo magnético forte por bilhões de anos (Zuluaga e Cuartas, 2012; Zuluaga et al., 2013a). Somando-se a isso que estrelas de menos de $\sim 0,5-0,8 \mathrm{M}_{\odot}{ }^{6}$ podem ter menos planetas de massa superior a $0,3 \mathrm{M}_{\oplus}$ (Raymond et al., 2007) e que estrelas M teriam maior propensão a terem planetas rochosos super pobres ou super ricos em água (Tian e Ida, 2015) e temos um panorama ambivalente com relação às estrelas $\mathrm{M}$ ou até K. Especificamente em nosso trabalho, temos limitações técnicas com relação às estrelas de baixa massa. Utilizamos os albedos planetários de Kasting et al. (1993), que vão inferiormente apenas até $\sim 0,5 \mathrm{M}_{\odot}$, o que nos faz aderir a essa massa como limite inferior em nossa análise. Superiormente, algo como estrelas F ( $\left.1,4 \mathrm{M}_{\odot}\right)$ seriam o limite. Estrelas mais massivas evoluem rapidamente e não só saem em pouco tempo da sequência principal como também transladam a ZHC mais rapidamente no tempo.

Rumando para a maior escala em nosso estudo, a Galáxia, temos que a incidência de mais ou menos planetas de certo tipo - rochosos, gasosos, etc - pode estar correlacionada à parâmetros da estrela, já que ambos se formaram da mesma nuvem de gás. Isso é extensivamente discutido adiante, mas a metalicidade e a massa estelares parecem estar envolvidas. Isso é especialmente relevante ao tentar amarrar, ou conectar, as características

\footnotetext{
${ }^{6} \odot$ é o símbolo do Sol.
} 
mais locais, de escala planetária e estelar, com a grande escala Galáctica, pois a distribuição de estrelas de certo tipo, massa, idade ou metalicidade não é homogênea na Galáxia.

Em analogia à ZHC, poderia haver uma zona de habitabilidade Galáctica (ZHG) (Gonzalez et al., 2001). A ZHC está atrelada à ideia de água líquida por longos períodos de tempo, já a ZHG seria a região com as melhores condições para manter o maior número de planetas rochosos habitáveis. Seus limites seriam bem menos definidos. Desde os anos 1980 que esse conceito vem sendo desenvolvido mais cuidadosamente (Balazs, 1988; Marochnik e Mukhin, 1988), mas foi somente com Gonzalez et al. (2001) que ele foi concebido como é tido hoje.

É comum na literatura considerar a influência que eventos de escala Galáctica de alta energia ou potencialmente esterilizantes teriam na vida. Alguns deles seriam supernovas (Gonzalez et al., 2001; Lineweaver, 2001; Gehrels et al., 2003; Lineweaver et al., 2004; Prantzos, 2008; Gowanlock et al., 2011), Gamma-Ray Burts (GRB) (Annis, 1999; Galante, 2009), perturbações gravitacionais de outras estrelas que poderiam influenciar na nuvem de Oort do sistema, aumentando a frequência de impactos cometários (Gonzalez et al., 2001), nuvens moleculares gigantes (McCrea, 1975), dentre outros. Nós não vamos considerar isso aqui. Em parte é por limitações técnicas. Nosso modelo de evolução química da Galáxia, como outros da literatura (Lineweaver et al., 2004; Prantzos, 2008; Gowanlock et al., 2011), não inclui cinemática estelar. Embora fosse possível fazer estimativas, já temos muito no que trabalhar. Uma motivação mais profunda é que pode ser que muitos desses eventos sejam muito importantes para a chamada vida complexa, mas menos importantes para a vida dita simples.

Gehrels et al. (2003) estimaram que uma supernova tipo II típica a 8 pc de distância da Terra destruiria aproximadamente metade da camada de ozônio, expondo a superfície à radiação UV do Sol. Supernovas tipo Ia são mais luminosas e poderiam provocar o mesmo efeito de distâncias maiores. Isso poderia ter efeitos desastrosos para a biosfera considerando o efeito que radiação de $\lesssim 300 \mathrm{~nm}$ pode ter no DNA (Cockell e Raven, 2007). Inclusive, supernovas são sugeridas como possíveis causadoras de extinções em massa durante o Fanerozoico ${ }^{7}$ (Fields e Ellis, 1999; Benitez et al., 2002; Melott et al., 2004; Svensmark, 2012). O problema é que o foco dos trabalhos que usam essas estimativas para o dano causado por supernovas é em épocas mais recentes da história natural do

\footnotetext{
${ }^{7}$ De 541 milhões de anos atrás até hoje.
} 
planeta (quando havia uma camada de ozônio para ser destruída) e em vida terrestre, diurna e complexa (que é a vida que seria diretamente atingida e prejudicada por radiação UV solar se a camada de ozônio protetora subitamente fosse danificada). Durante boa parte do tempo em que houve vida no planeta não havia camada de ozônio para atenuar a radiação UV do Sol, porque os níveis de oxigênio eram bem baixos. O Sol até produzia mais radiação UV no passado, mas isso não impediu a vida de existir e prosperar em nosso planeta. Os organismos da época poderiam ter se protegido sob o solo ou sob a água (Heath et al., 1999).

Há resultados variados na literatura quanto à exposição de micro-organismos à radiação UV (em especial ao redor de $254 \mathrm{~nm}$ ), mas que concordam que a radiação UV é bastante danosa quando em níveis acima do que os micro-organismos estão abituados, mesmo quando possuem mecanismos de proteção intracelular (Ewing, 1995; Gascón et al., 1995; Joux et al., 1999; Sommer et al., 2001; Alcántara-Díaz et al., 2004; Lehtola et al., 2003; Hijnen et al., 2006; Zenoff et al., 2006; Coohill e Sagripanti, 2008; Krisko e Radman, 2010; Abrevaya et al., 2011; Goldman e Travisano, 2011). Embora a radiação UV possa penetrar até dezenas de metros na água, isso é fortemente dependente das substâncias e dos particulados dissolvidos na água (Wilhelm et al., 2002; Liu, 2005; Vantrepotte e Mélin, 2006); mais matéria orgânica dispersa na água (Cleaves e Miller, 1998) ou a fuga dos organismos para águas mais profundas durante o dia (Rautio e Tartarotti, 2010) podem ser mecanismos de defesa bem eficientes contra a radiação UV. Então, embora seja extremamente importante o efeito de supernovas para nós, Homo sapiens, acreditamos que supernovas possam ser desprezadas em primeira aproximação ao estimar a habitabilidade considerando a vida microbial de boa parte da história natural de nosso planeta.

Comentaremos ao longo do texto a respeito de definições e limitações, mas, de maneira geral, os termos "planeta" e "exoplaneta" são usados de maneira intercambiável. Quando precisarmos especificar se estamos falando exclusivamente de planetas do Sistema Solar ou de outros sistemas explicitaremos isso. Os termos "rochoso", "telúrico" e "terrestre" são encontrados associados aos planetas interiores do Sistema Solar (Mercúrio, Vênus, Terra e Marte) e a planetas sem análogo em nosso sistema, como superterras. Neste trabalho, usamos o termo "rochoso" para planetas basicamente constituídos por rochas e metais e de baixo teor de voláteis (quando comparados aos planetas gigantes gasosos, como Júpiter, Saturno, Urano e Netuno em nosso sistema), com massas variando de $\sim 0,01 \mathrm{M}_{\oplus}$ (grandes 
luas do Sistema Solar) até $\sim 10 \mathrm{M}_{\oplus}$ (superterras sem análogos em nosso sistema estelar). É um termo amplo e fracamente definido, mas ainda útil quando usado em oposição aos planetas gigantes gasosos. Chamamos de "telúrico" os planetas rochosos no intervalo de massas de nosso interesse, de $0,1-4,0 \mathrm{M}_{\oplus}$ e de composição primordial de rochas e metais (então algo separados dos rochosos mais ricos em gelos ou voláteis como as grandes luas dos planetas gigantes gasosos em nosso sistema). Por fim, usamos "terrestre" de duas maneiras: a mais frequente é extritamente ligada ao nosso planeta, substituto de "da Terra"; outra, mais rara, é de um modo menos preciso, para os planetas telúricos de massa ao redor da massa da Terra e de demais propriedades semelhantes às terrestres, mas não significando estritamente um planeta gêmeo da Terra. Dessa forma, limitamos nosso estudo à planetas telúricos em estrelas FGK $\left(0,5-1,3 \mathrm{M}_{\odot}\right)$ na sequência principal no disco de nossa Galáxia.

\subsection{Motivações}

A figura 1.1 ilustra a posição dos exoplanetas confirmados até recentemente e com distância da estrela ao Sistema Solar determinada. A distribuição não espelha a distribuição real, é produto da maior facilidade de observar os objetos próximos da Terra. A maioria está localizada a até $1-2 \mathrm{kal}^{8}$, mas há duas excursões relevantes. Por volta de $80^{\circ}$ até $\sim 5$ kal estão os exoplanetas descobertos pelo Kepler ${ }^{9}$ E em direção ao centro da Galáxia, até $\sim 30 \mathrm{kal}$, estão os exoplanetas descobertos pela técnica de microlentes gravitacionais (gravitational microlensing). Há muito espaço para exploração que poderia ser feita de maneira mais focada e orientada.

Nosso objetivo é estudar a habitabilidade da Via-Láctea desde a escala planetária até a escala Galáctica para derivar as características melhor associadas à habitabilidade planetária e as regiões de nossa Galáxia mais promissoras quanto à procura por vida. Não igualamos habitável com habitado, mas ser habitável é uma condição necessária para ser habitado. Temos diversas limitações em escopo, técnicas ou conceitos, mas pensamos nosso trabalho como o primeiro termo, ou primeiros termos, de uma expansão em série de funções que descreveriam a habitabilidade dos sistemas estudados. Sendo somente os primeiros termos os resultados podem ser algo imprecisos, mas, esperamos, na direção correta. Além de servir para explorar a habitabilidade do sistema Terra de maneira mais unida e de

\footnotetext{
${ }^{8}$ Kilo ano-luz.

${ }^{9} \mathrm{O}$ descomissionado telescópio espacial, não o famoso astrônomo dos séculos XVI e XVII.
} 


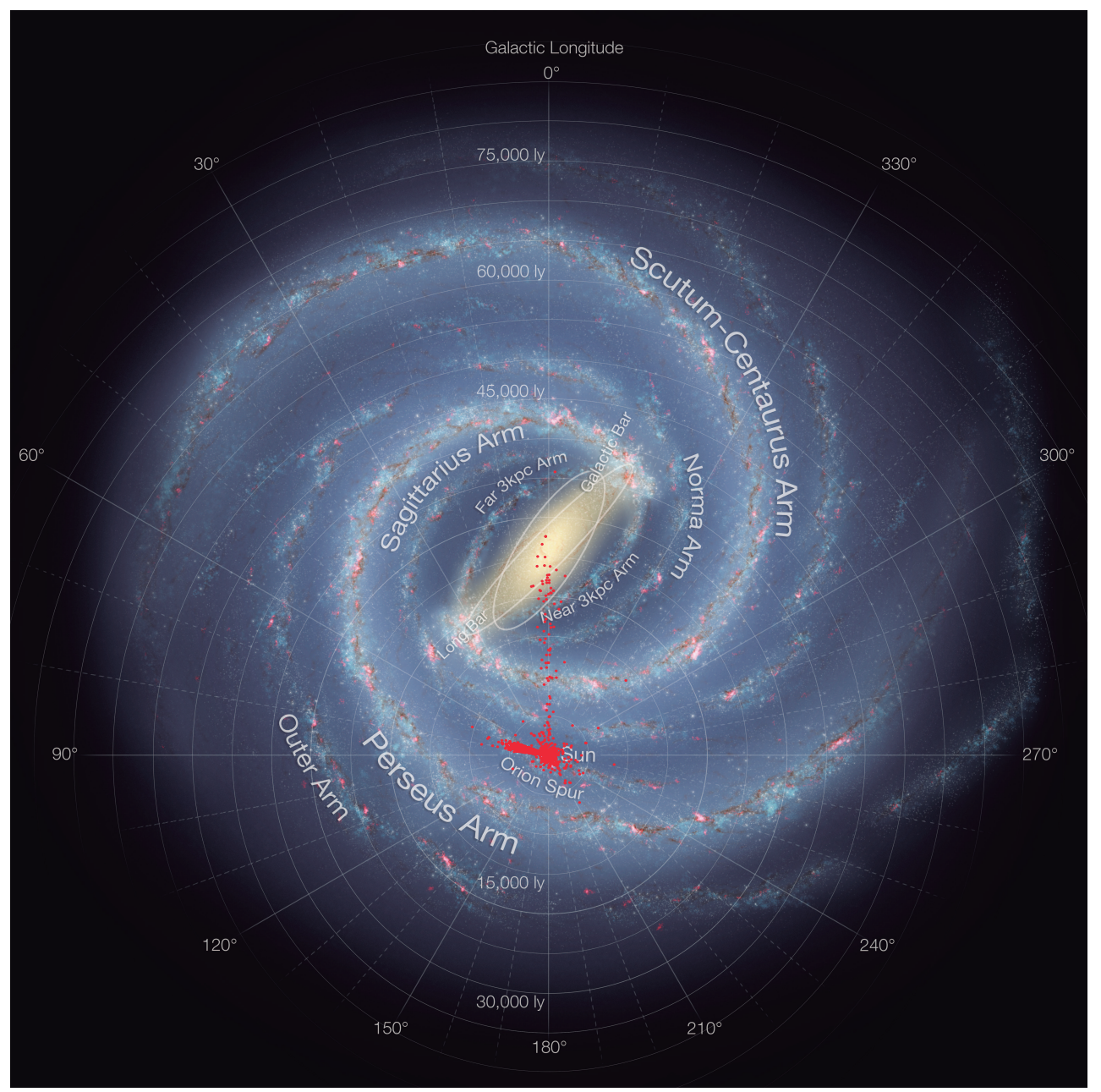

Figura 1.1: Distribuição no plano do disco da Via-Láctea dos exoplanetas confirmados até 20/03/2019 e com distância da estrela até os Sistema Solar determinada no banco de dados de exoplanet.eu (pontos vermelhos) sobreposta à uma ilustração no visível da Via-Láctea de NASA/JPL-Caltech/R. Hurt (SSC/Caltech).

aprofundar e conectar nosso conhecimento sobre a habitabilidade em várias escalas na Galáxia, nosso trabalho pode servir para orientar futuros programas de busca por exoplanetas habitáveis na Galáxia.

\subsection{Estrutura da Tese}

Esta tese está dividida em introdução, quatro capítulos de desenvolvimento, nos quais estudamos a habitabilidade da Via-Láctea em escalas sucessivamente maiores, e conclusão. Em cada capítulo tentaremos derivar importantes resultados a respeito de habitabilidade, aplicando-os no capítulo seguinte em uma escala maior, caminhando da escala terrestre e planetária para a escala Galáctica. 
O primeiro capítulo de desenvolvimento, Capítulo 2, é o mais longo e mais básico, onde desenvolvemos um modelo da co-evolução da geosfera, atmosfera e biosfera da Terra para estudar sua habitabilidade ao longo do tempo. Comparamos as previsões do modelo para o passado e presente do planeta para melhor avaliar sua confiabilidade e limitações quanto às previsões para o futuro da biosfera, seu declínio e o fim da habitabilidade da Terra.

No segundo capítulo, Capítulo 3, são feitas pequenas modificações ao modelo de habitabilidade terrestre de maneira a torná-lo aplicável a uma maior gama de parâmetros planetários. Nós testamos a variação de alguns desses parâmetros e tentamos obter indicações de quais características planetárias favoreceriam a habitabilidade a longo prazo.

No terceiro capítulo de desenvolvimento, Capítulo 4, estudamos mais profundamente o papel do tempo e da estrela na habitabilidade planetária e nos limites da ZHC, derivando uma função geral para a largura da ZHC em função da massa e da idade da estrela.

O último capítulo de desenvolvimento, Capítulo 5, é onde terminamos a análise da habitabilidade em função da estrela, explorando a relação entre metalicidade e massa estelar com a incidência de planetas telúricos. Descrevemos como conectamos todas as derivações anteriores e as aplicamos em escala Galáctica através de um modelo de evolução química do disco Galáctico.

O último capítulo resume as considerações e derivações mais importantes do trabalho e faz a indicação dos melhores parâmetros planetários e regiões na Via-Láctea para a procura por vida. 
Capítulo 2

\section{Habitabilidade da Terra}

Neste capítulo desenvolvemos um modelo da co-evolução da geosfera, atmosfera e biosfera, focando principalmente na evolução térmica do planeta. Esse modelo (Mello e Friaça, 2019) é aplicado ao caso terrestre, onde comparamos com as evidências quanto ao passado do planeta e aos outros modelos da literatura, estimando a expectativa de vida da biosfera.

\subsection{Modelo de Evolução Térmica}

A equação fundamental de nosso modelo de evolução térmica parte da conservação global de energia no interior na geosfera (Christensen, 1985), com a variação da temperatura interna, $\frac{d T_{i}}{d t}$, sendo proporcional à energia gerada internamente, $H$, menos a energia convectivamente perdida para a superfície, $Q$ :

$$
C_{T} \frac{d T_{i}}{d t}=H-Q
$$

Não discriminamos entre as contribuições do núcleo e do manto, para a qual uma parametrização núcleo-manto seria necessária, embebendo a participação do núcleo em $C_{T}$, a capacidade térmica efetiva da Terra inteira. A equação 2.1 é bem geral e pode ser adaptada a muitos sistemas com transferência de energia, sendo a temperatura interna a temperatura interna média do sistema modelado. O manto terrestre possui uma grande variação de temperaturas e pressões, uma temperatura comumente usada para caracterizálo é a temperatura potencial, $T_{P}$, definida como a temperatura que uma parcela do manto teria se fosse trazida de seu local e pressão adiabaticamente até uma pressão de referência (em geral a superfície à $1 \mathrm{~atm}$ ) (McKenzie e Bickle, 1988). Seguindo Korenaga (2006) e Korenaga (2008) vamos tomar a temperatura interna pela temperatura potencial média 
do manto, $T_{m}$, e modelar a evolução térmica da Terra pela evolução térmica do manto Korenaga (2006, 2008). A maioria das constantes e parâmetros desse capítulo são dados na Tabela 2.2.

A equação 2.1 nos diz que $T_{m}$ pode até aumentar dependendo do equilíbrio entre as componentes do lado direito, e que, isolando $Q$, o fluxo de calor para a superfície é basicamente constituído de duas componentes, uma relativa à energia gerada internamente e outra devida ao resfriamento secular. A relação entre essas duas componentes será importante mais para frente ao falarmos da razão de Urey.

A energia gerada internamente vem do decaimento de material radioativo, principalmente os isótopos ${ }^{238} \mathrm{U},{ }^{235} \mathrm{U},{ }^{232} \mathrm{Th}$ e ${ }^{40} \mathrm{~K}$, de longa meia-vida. Isótopos radioativos de meia-vida curta (como ${ }^{26} \mathrm{Al}$, com meia-vida de $7,3 \times 10^{5}$ anos) devem ter contribuído bastante inicialmente, mas têm pouca presença nas escalas de tempo de nosso interesse e no futuro do planeta, então não vamos considerá-los inicialmente.

Tabela 2.1 - Parâmetros da equação 2.2 usando dados de Arevalo Jr et al. (2009).

\begin{tabular}{cccc}
\hline & Taxa de liberação de energia & Meia-vida & Concentração no manto primitivo \\
Isótopo & $h_{i}$ & $t_{1 / 2}^{i}$ & $C_{i}$ \\
& $\mathrm{~W} \mathrm{~kg}^{-1}$ & anos & $\mathrm{kg} \mathrm{kg}^{-1}$ \\
\hline${ }^{238} \mathrm{U}$ & $9,46 \times 10^{-5}$ & $4,47 \times 10^{9}$ & $4,255 \times 10^{-8}$ \\
${ }^{235} \mathrm{U}$ & $5,69 \times 10^{-4}$ & $7,04 \times 10^{8}$ & $1,382 \times 10^{-8}$ \\
${ }^{232} \mathrm{Th}$ & $2,64 \times 10^{-5}$ & $1,40 \times 10^{10}$ & $1,055 \times 10^{-7}$ \\
${ }^{40} \mathrm{~K}$ & $2,92 \times 10^{-5}$ & $1,25 \times 10^{9}$ & $4,484 \times 10^{-7}$ \\
\hline
\end{tabular}

É comum na literatura simplificar a contribuição de ${ }^{238} \mathrm{U},{ }^{235} \mathrm{U},{ }^{232} \mathrm{Th}$ e de ${ }^{40} \mathrm{~K}$ por uma única componente efetiva exponencial. Esse tratamento não difere muito do caso com quatro componentes, uma para cada isótopo, quando se modela o passado da Terra, mas se torna relevante no futuro, já que as concentrações e os tempos de meia-vida são diferentes, tornando a contribuição do ${ }^{232} \mathrm{Th}$ importante relativamente às outras componentes e distanciando o comportamento de um tratamento de quatro componentes daquele com somente uma. Por isso preferimos discriminar entre as quatro componentes na forma:

$$
H(t)=f_{r m}\left[\sum_{i} C_{i} h_{i} \times \exp \left(-\frac{t \times \ln (2)}{t_{1 / 2}^{i}}\right)\right] M_{m}
$$


onde $f_{r m}$ é a fração de todo material radioativo ainda presente no manto, $i$ é o índice para os isótopos, $C_{i}$ é a concentração inicial no manto primitivo do isótopo $i, h_{i}$ é a taxa de geração de energia do isótopo $i, t_{1 / 2}^{i}$ é o tempo de meia-vida do isótopo $i$, e $M_{m}$ é a massa do manto. A perda total de energia do interior para a superfície do planeta é de 46 TW (Jaupart et al., 2007; Arevalo Jr et al., 2009; Korenaga, 2008). Desses, 38,7 TW são perdidos convectivamente do manto para a superfície, $21 \mathrm{TW}$ têm origem radioativa no manto e na crosta continental, e apenas 13,7 TW são gerados radioativamente no manto (Jaupart et al., 2007; Arevalo Jr et al., 2009). As concentrações iniciais (no manto primitivo, em $t=0$ no modelo) dos isótopos foram calculadas a partir das concentrações atuais para toda a Terra de silicato (bulk silicate Earth) fornecidas em Arevalo Jr et al. (2009) usando a lei do decaimento radioativo. Explicamos mais a frente como modelamos a fuga de material radioativo do manto para a crosta continental dada pelo fator $f_{r m}$.

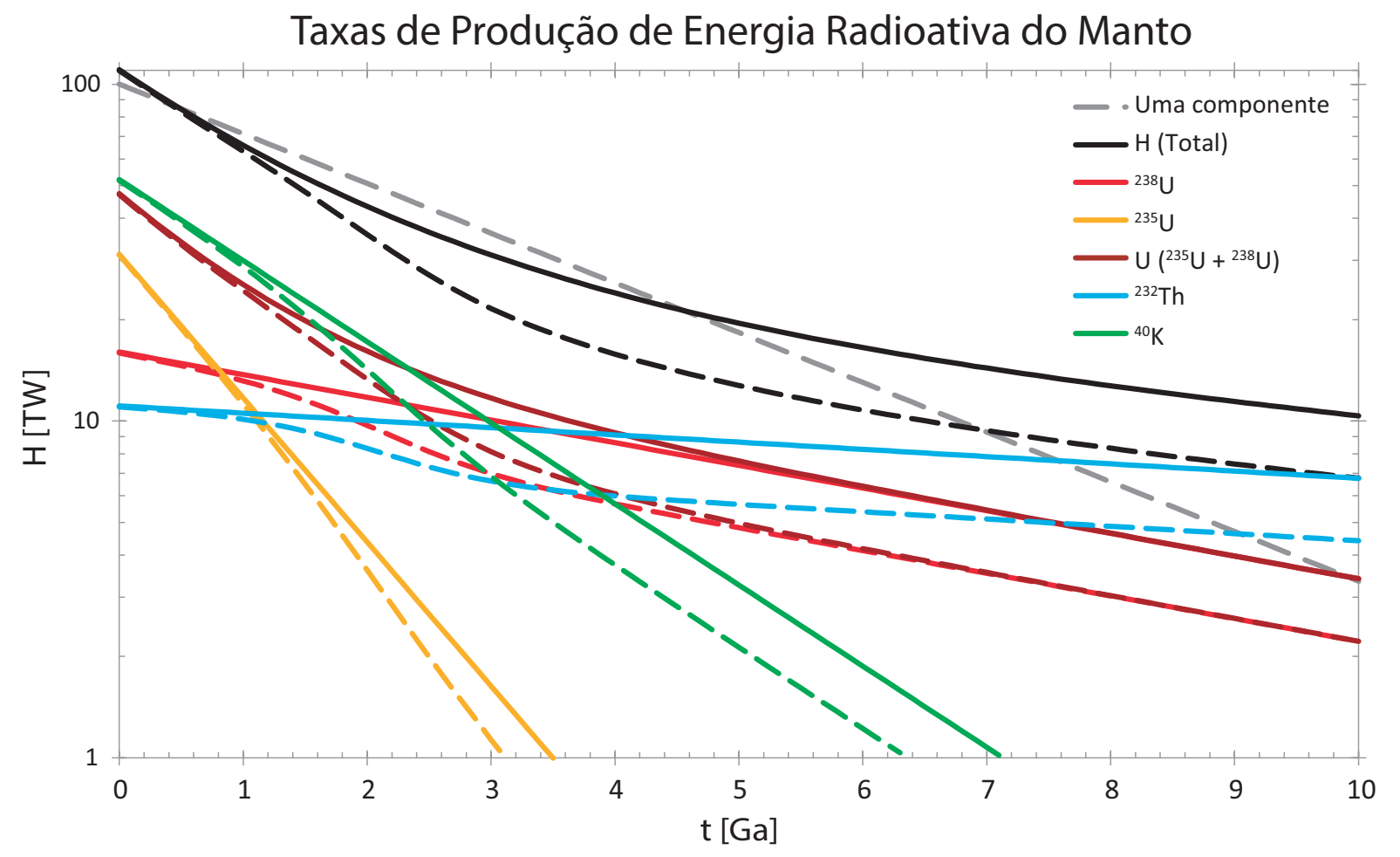

Figura 2.1: Potência total de cada isótopo radioativo. Linhas cheias indicam valores do manto mais a crosta. Linhas tracejadas indicam valores somente do manto. A linha tracejada cinza é para um modelo de apenas uma componente exponencial para fins de comparação.

Para a viscosidade do manto usamos uma função do tipo Arrhenius (Korenaga, 2013), dependente da temperatura potencial média do manto (Korenaga, 2010) e de constantes listadas na Tabela 2.2: 


$$
\eta=\eta_{0} \exp \left[\frac{E}{R}\left(\frac{1}{T_{m}}-\frac{1}{T_{0}}\right)\right]
$$

onde $\eta_{0}$ é a viscosidade de referência na temperatura de referência $T_{0}$, $E$ é a energia de ativação, e $R$ é a constante molar dos gases ideais. Alguns modelos (McGovern e Schubert, 1989; Franck e Bounama, 1995) incluem uma dependência da viscosidade também com a quantidade de água no manto, com o manto se tornando menos viscoso quanto mais água houver. Devido a dificuldades em quantificar esse efeito, preferimos a versão mais simples, usada em Conrad e Hager (1999a) e Korenaga (2006), dependente apenas da temperatura.

É comum os modelos parametrizados de evolução térmica da Terra apresentarem um fluxo de calor proporcional à diferença de temperatura a que o sistema está sujeito (a temperatura da base do manto e a temperatura da base da litosfera na realidade, mas a temperatura potencial média do manto e uma temperatura superficial no nosso caso, como aproximação) e a uma potência, $\beta$, do número de Rayleigh, $R a$ :

$$
Q \propto \Delta T R a^{\beta}
$$

Como o número de Rayleigh, em sua forma mais comumente utilizada em modelos de evolução térmica do manto, depende de $\Delta T$ e inversamente de $\eta$, o fluxo de calor acaba dependendo de uma potência $1+\beta$ de $\Delta T$, $\operatorname{com} \beta$ sendo mais comumente $\sim 0,3$ na literatura (Christensen, 1985; McGovern e Schubert, 1989; Franck e Bounama, 1995). Essa parametrização tem êxito em modelar parte da evolução térmica da Terra, mas falha ao prever uma temperatura do manto muito alta no passado, pois seria necessário um intenso resfriamento secular para manter o fluxo de calor atual; ou falha ao prever uma maior quantidade de material radioativo no manto, o que contraria as evidências geoquímicas (Korenaga, 2008; Lenardic et al., 2011). Variar o expoente $\beta$ é uma solução possível e muito sobre isso foi discutido na literatura (Christensen, 1985; Korenaga, 2003, 2006), outra solução, que usamos em nosso modelo, é não só mudar o expoente, como mudar a parametrização do fluxo de calor. Empregamos a forma dada por Conrad e Hager (1999a,b) e Korenaga (2006) que considera o fluxo de calor de um manto completamente convectivo em um regime de tectônica de placas: 


$$
Q=A\left[\frac{C_{1} \alpha \rho_{m} g\left(T_{m}-T_{S, 0}\right)^{3}\left(R_{e}-R_{i}\right) h}{C_{2} \eta+C_{3} \eta_{L}\left(h / R_{c p}\right)^{3}}\right]^{\frac{1}{2}}
$$

onde $A$ é uma constante ajustável para fornecer a perda de energia por convecção do manto de 38,7 TW, $\alpha$ é o coeficiente de expansão térmica, $\rho_{m}$ é a densidade média do manto superior, $g$ é a aceleração da gravidade, $T_{S, 0}$ é a temperatura superficial de referência, $R_{e} \mathrm{e}$ $R i$ são, respectivamente, o raio exterior e interior do manto, $h$ é a espessura de placa, $\eta_{L}$ é a viscosidade da litosfera, e $R_{c p}$ é um parâmetro relacionado ao raio de curvatura da placa. Com exceção de $T_{m}$ e $\eta$ os outros parâmetros são mantidos constantes. É bem provável que $h$ varie em função de $T_{m}$ e alguma forma dessa dependência possa ser encontrada na literatura (Korenaga, 2003, 2006), mas preferimos manter a equação mais simples fixando h. As constantes $C_{1-3}$ são constantes dadas em Conrad e Hager (1999a) com valores: $C_{1}=1 / \sqrt{\pi}, C_{2} \approx 13,5$ (Korenaga, 2006), e $C_{3} \approx 2,5$.

As equações anteriores expressam a parte "térmica" de nosso modelo, faltando a parte que expressa as trocas gasosas e uma conexão entre elas. Essa conexão é dada relacionando o fluxo de calor e a taxa de expansão do assoalho oceânico, $S_{r}$ (McGovern e Schubert, 1989; Franck, 1998):

$$
S_{r}=\frac{(\varphi q)^{2} \pi \kappa A_{b o}}{4 k^{2}\left(T_{m}-T_{S, 0}\right)^{2}},
$$

onde $\varphi$ é um fator corretivo (parâmetro livre) para $q$ de maneira a levar em conta heterogeneidades no fluxo de calor superficial no assoalho oceânico e nas dorsais oceânicas quando comparado com o fluxo médio, $q$ é o fluxo de calor em unidades por área $(Q$ dividido pela área da Terra), $A_{b o}$ é a área das bacias oceânicas, $\kappa$ é a difusividade térmica, e $k$ é a condutividade térmica.

A crosta continental concentra grande parte do material radioativo da Terra, produzindo 7,3(23) TW (Jaupart et al., 2007; Arevalo Jr et al., 2009), e deve ter concentrado esse material do manto ao crescer. A Figura 2.2 compara a curva de crescimento do volume da crosta continental em diferentes modelos.

Os modelos parecem concordar que o volume da crosta continental aumentou com o tempo e principalmente entre $\sim 3,5$ e $\sim 1,5$ Ga atrás, mas não muito além disso. O crescimento da crosta continental foi episódico, mas tendo por base a incerteza na forma da 


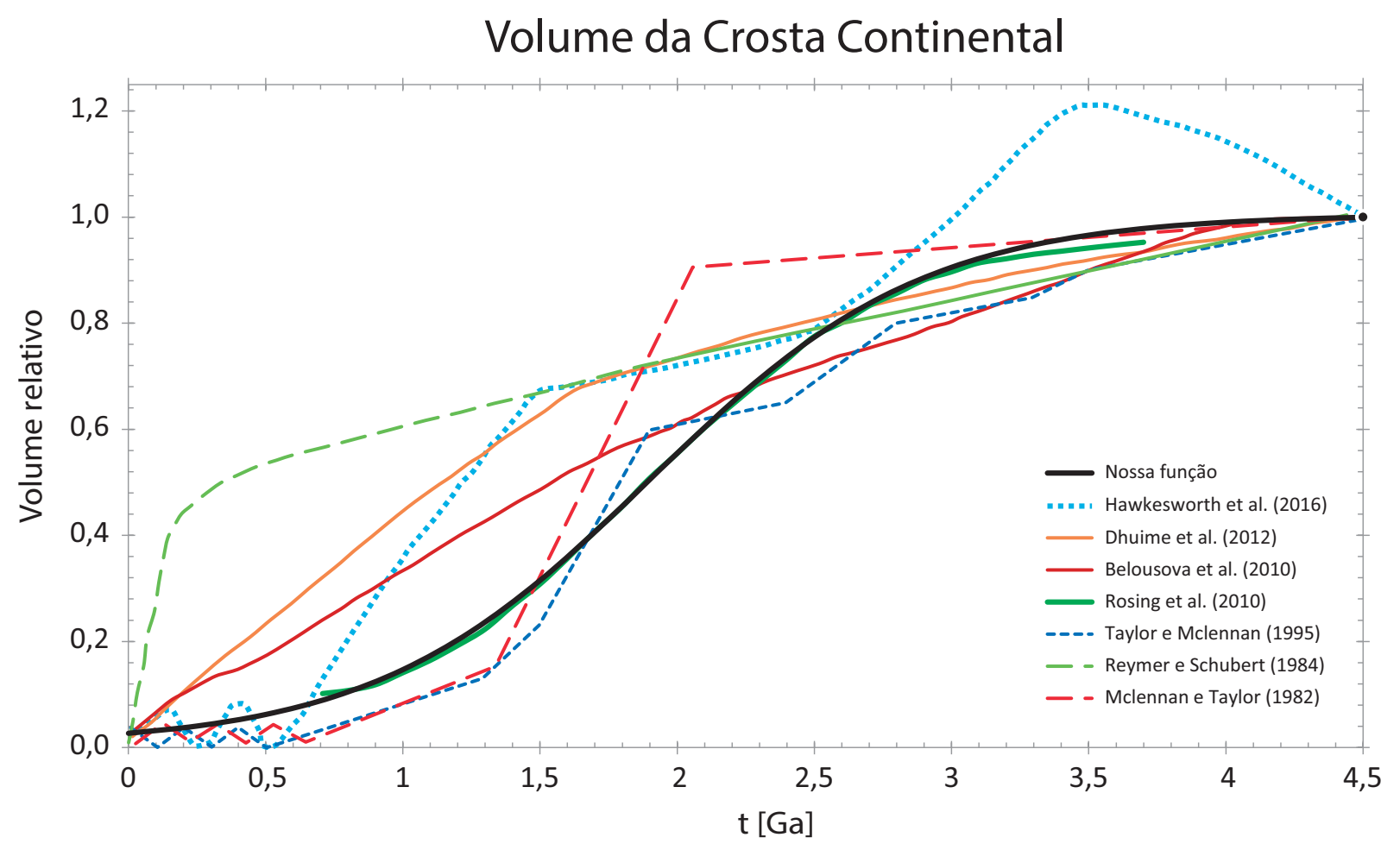

Figura 2.2: Volume da crosta continental dado por diferentes trabalho da literatura.

curva de crescimento e nosso interesse em aplicar o modelo a outros casos que não o terrestre, supomos um crescimento simples dado por uma função sigmoide, como apresentado em Rosing et al. (2010), com a área continental e o volume continental sendo diretamente proporcionais, e supondo que a área continental permanecerá constante no futuro por simplicidade:

$$
\begin{aligned}
& A_{c c}^{N}=\frac{1}{1+\exp [-2(t-2)]}, \\
& A_{b o}^{N}=1-f_{c c} A_{c c}^{N}, \\
& A_{b o}=A_{T} A_{b o}^{N},
\end{aligned}
$$

onde $A_{c c}^{N}$ é a área normalizada da crosta continental, $A_{b o}^{N}$ é a área normalizada das bacias oceânicas, $f_{c c}$ é a fração da superfície do planeta constituída de crosta continental, e $A_{T}$ é a área da Terra. Atualmente, $A_{b o}^{N} \approx 65 \%$, equivalendo a $A_{c c}^{N} \approx 35 \%$, o que é mais do que a fração de área superficial não ocupada por oceanos, pois há alguma transgressão marinha (avanço dos oceanos por sobre a placa continental). 
Retornando à equação 2.2, modelamos a perda gradual de material radioativo do manto para a crosta continental de maneira linear ao avolumamento da crosta constinental com o fator $f_{r m}$, ou seja, quanto mais volumosa (também de maior área em nossa aproximação) a crosta, menos material radioativo o manto conteria:

$$
f_{r m}=1-(7,3 / 21) A_{c c}^{N}
$$

onde o fator 7,3/21 é só a razão da produção de calor radioativo da crosta continental atual pela produção de calor radioativo do manto atual. Então $f_{r m}$ parte de um valor próximo de 1 quando $A_{c c}^{N} \approx 0$ em $t=0$ e vai caindo linearmente conforme a área continental normalizada vai aumentando, até estacionar no valor atual de $\sim$ 0,65 (1/3 da geração de energia radioativa atual teria origem na crosta continental).

\subsubsection{Trocas Gasosas}

A origem da água e de outros voláteis na Terra ainda é algo incerto e não vamos discutir isso aqui, mas uma revisão da literatura pode ser encontrada em Genda (2016). Supondo a água como primordial, as trocas gasosas entre o manto e a superfície podem ser modeladas pelas equações 2.9 e supondo que a perda de água pelo manto para a superfície e o ganho de água pelo manto ocorrem, respectivamente, quando nova área do assoalho oceânico é formada e quando a crosta oceânica sofre subducção e afunda no manto, mas, como a eficiência desses processos é pouco conhecida, alguns parâmetros relevantes são deixados parcialmente livres para fornecer o volume atual dos oceanos. É preciso também estimar o tamanho dos reservatórios do manto e da superfície (veja a Figura 2.3). Enquanto na superfície esse valor é trivial (um(a) volume(massa) oceânico(a), $\mathrm{M}_{\mathrm{oc}}$ ), é bem incerta a quantidade de água no manto terrestre, com estimativas variando de 0,1 a 11 vezes o volume dos oceanos atuais (Liu, 1988; Ahrens, 1989; Jambon e Zimmermann, 1990; Smyth, 1994; Dai e Karato, 2009; Genda, 2016; Kurokawa et al., 2018).

Considerando tais incertezas e que muitos trabalhos usam valores próximos de $3,0 \mathrm{M}_{\mathrm{oc}}$ em seus modelos (McGovern e Schubert, 1989; Franck e Bounama, 1995; Franck et al., 2002) decidimos pelo conservador valor de 2,0 $\mathrm{M}_{\mathrm{oc}}$ no manto atual. A repartição entre os dois reservatórios pode ser ainda mais incerta no estado inicial (em $t=0)$, com alguns modelos supondo toda a água concentrada no manto e nada na superfície (McGovern e Schubert, 


\section{Água no Manto}

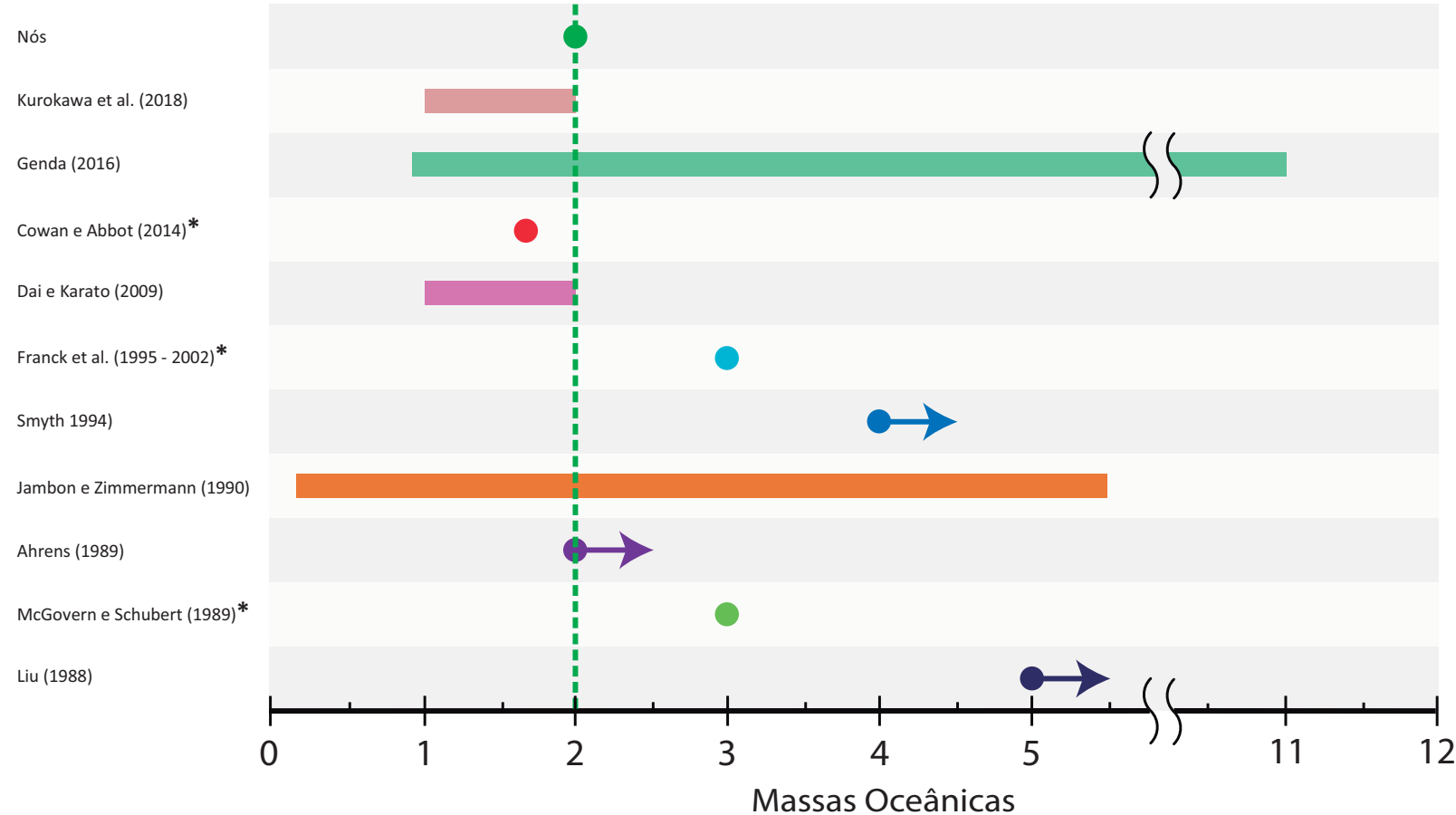

Figura 2.3: Estimativas da quantidade de água no manto por diferentes trabalhso da literatura dada em massas oceânicas superficiais atuais. Referências com um asterisco são de valores usados em modelos.

1989; Franck e Bounama, 1995) e outros partindo da mesma repartição de agora (Franck e Bounama, 1997; Franck, 1998; Bounama et al., 2001; Franck et al., 2002). Considerando nossa ignorância a respeito do estado inicial, vamos supor a mesma repartição atual, então 2,0 $\mathrm{M}_{\mathrm{oc}}$ no manto e 1,0 $\mathrm{M}_{\mathrm{oc}}$ na superfície, o que é supor que já havia grandes quantidades de água na superfície terrestre após 70 Ma da formação do Sistema Solar, o que é razoável considerando os achados de zircões de Wilde et al. (2001), evidenciando oceanos e crosta continental há 4,4 Ga.

A taxa de aumento da massa de água no manto, $d M_{a m} / d t$, é dado pela relação entre a taxa de regaseificação, $\left[d M_{a m} / d t\right]_{r}$, e desgaseificação, $\left[d M_{a m} / d t\right]_{d}$, de água:

$$
\begin{aligned}
& \frac{d M_{a m}}{d t}=\left[\frac{d M_{a m}}{d t}\right]_{r}-\left[\frac{d M_{a m}}{d t}\right]_{d}, \\
& {\left[\frac{d M_{a m}}{d t}\right]_{r}=f_{a b a s} \rho_{b a s} d_{h} f_{r} S_{r},} \\
& {\left[\frac{d M_{a m}}{d t}\right]_{d}=\rho_{a m} d_{d} f_{d} S_{r},}
\end{aligned}
$$


onde $f_{a b a s}$ é fração por massa da quantidade de água na crosta oceânica, $\rho_{\text {bas }}$ é a densidade média da crosta oceânica, $d_{h}$ é a profundidade de hidratação da crosta oceânica, $f_{r}$ é um parâmetro livre para a eficiência com que a água na crosta oceânica de fato adentra o manto em vez de retornar para a superfície e é escolhido de maneira a fornecer a massa atual de água na superfície, $\rho_{a m}$ é a densidade de água no manto (massa de água dividida pelo volume do manto), $d_{d}$ é a profundidade a partir de onde a água pode desgaseificar nas áreas de expansão do assoalho oceânico, e $f_{d}$ é um parâmetro para a eficiência com que a água no volume $S_{r} d_{d}$ de fato pode ser expelida para a superfície em vez de retornar para o manto. Nem todos os parâmetros acima são mantidos constantes e seguimos Cowan e Abbot (2014) em sua formulação para $d_{h}$ e $f_{d}$ :

$$
\begin{aligned}
& d_{h}=\min \left[d_{h, 0}\left(\frac{P}{P_{o c}}\right)^{\sigma}, d_{b a s}\right], \\
& f_{d}=\min \left[f_{d, 0}\left(\frac{P}{P_{o c}}\right)^{-\mu}, 1\right], \\
& P=g \rho_{a} d_{o c} \\
& d_{o c}=\frac{M_{a s}}{\rho_{a} A_{b o}}
\end{aligned}
$$

onde min indica escolher o valor mínimo dentre as duas opções, $P$ é a pressão no fundo do oceano, $P_{o c}$ é uma pressão de referência com o valor atual na Terra, $d_{b a s}$ é a espessura média da crosta oceânica, $d_{h, 0}$ é o valor nominal da profundidade de hidratação, $f_{d, 0}$ é o valor nominal do parâmetro $f_{d}, \sigma$ e $\mu$ são expoentes que quantificam a dependência com a pressão, $\rho_{a}$ é a densidade da água, $d_{o c}$ é a profundidade efetiva dos oceanos, e $M_{a s}$ é a massa de água na superfície.

A profundidade efetiva dos oceanos foi calculada usando a aproximação de Cowan e Abbot (2014), onde as bacias oceânicas têm todas a mesma profundidade e com o topo dos continentes ao nível do mar. Claro que o topo das montanhas e uma parte considerável dos continentes está bem acima do nível do mar, mas a aproximação diz que essa parte seria desprezível frente à profundidade das bacias oceânicas. Considerando nossa suposição de que a área dos continentes aumenta com o volume da crosta continental, as bacias oceânicas ficariam com uma área menor com o tempo (porque os continentes ocupariam maior área), mas compensariam ficando mais profundas. 
A profundidade máxima que os oceanos podem ter antes de cobrirem até o topo dos continentes na Terra é dada por Cowan e Abbot (2014) $\operatorname{com} d_{o c}^{m a x}=11,4 \mathrm{~km}$. Para o valor mínimo vamos seguir Abe et al. (2011) $\operatorname{com} d_{o c}^{\text {min }}=0,5 \mathrm{~m}$, onde um planeta bem seco, mas ainda com água suficiente para ser habitável, teria um "oceano" de profundidade efetiva da ordem de dezenas de centímetros. Como estamos usando uma profundidade efetiva alguns comportamentos podem passar desapercebidos, por exemplo, as irregularidades e porosidades do terreno, fazendo com que dificilmente tal oceano raso se constituiria de fato de um grande corpo de água, provavelmente estando mais espalhado em poças ou disperso no solo e na atmosfera.

A transgressão marinha completa, cobrindo até o topo das montanhas, pode não parecer um cenário tão apocalíptico (do ponto de vista astrobiológico da habitabilidade), pois haveria muita água líquida para a vida. Mas isso ignora todos os processos estabilizantes que necessitam de terra seca para acontecer e das consequências de toda a massa d'água superficial.

Grandes quantidades de água superficial facilitariam a entrada em regimes de efeito estufa úmido ou desenfreado, já que água é o gás estufa mais abundantemente disponível (Kasting et al., 1993). Planetas secos, com muito menos água superficial, poderiam se manter habitáveis por mais tempo conforme suas estrelas aumentassem de luminosidade (Abe et al., 2011). O termostato do ciclo do carbono (mais sobre isso na seção 2.3) depende de alguma superfície seca na qual as intempéries possam agir. Embora essa área possa ser pequena (Abbot et al., 2012), então os oceanos poderiam cobrir uma fração maior da superfície da Terra sem prejudir muito tal mecanismo, alguma área ainda seria necessária. O intemperismo continental também escoa grandes quantidades de minerais e nutrientes dos continentes para os oceanos e águas rasas, e essas poderiam ser essenciais para acumular os nutrientes necessários para a vida surgir e se manter (Schaefer e Sasselov, 2015). A completa ausência de terra seca poderia paralizar completamente o ciclo do carbono geológico e dificultar o acesso de criaturas marinhas a fontes importantes de nutrientes, diminuindo a habitabilidade do planeta. 
Tabela 2.2 - Parâmetros e constantes do modelo de evolução térmica e de trocas gasosas.

B86 = Bevis (1986), CH99a = Conrad e Hager (1999a), CH99b = Conrad e Hager (1999b),

CA14 = Cowan e Abbot (2014), K06 = Korenaga (2006), K10 = Korenaga (2010), MS89=

McGovern e Schubert (1989), S80 = Schubert et al. (1980), S81 = Stacey (1981).

\begin{tabular}{|c|c|c|c|}
\hline Símbolo & Descrição & Valor & Referência \\
\hline$C_{T}$ & Capacidade térmica efetiva de toda a Terra & $6,93 \times 10^{27} \mathrm{~J} \mathrm{~K}^{-1}$ & S 81 \\
\hline$M_{m}$ & Massa do manto & $4,06 \times 10^{24} \mathrm{~kg}$ & MS89 \\
\hline$M_{o c}$ & Massa de água nos oceanos atuais & $1,4 \times 10^{21} \mathrm{~kg}$ & MS89 \\
\hline$\eta_{0}$ & Viscosidade de referência & $10^{19} \mathrm{~Pa} \mathrm{~s}$ & K10 \\
\hline$\eta_{L}$ & Viscosidade efetiva da litosfera & $10^{23} \mathrm{~Pa} \mathrm{~s}$ & CH99a \\
\hline$E$ & Energia de ativação & $300 \mathrm{~kJ} \mathrm{~mol}^{-1}$ & K06 \\
\hline$R$ & Constante dos gases ideais & $8,314 \mathrm{Jmol}^{-1} \mathrm{~K}^{-1}$ & \\
\hline$T_{0}$ & Temperatura de referência & $1623 \mathrm{~K}$ & K10 \\
\hline$A$ & Constante (ajustada) & $1,40 \times 10^{15} \mathrm{WK}^{-1} \mathrm{~m}^{-0,5} \mathrm{~s}^{0,5}$ & \\
\hline$C_{1}$ & Constante 1 & 0,564 & CH99a, CH99b, K06 \\
\hline$C_{2}$ & Constante 2 & 13,5 & CH99a, CH99b, K06 \\
\hline$C_{3}$ & Constante 3 & 2,5 & CH99a, CH99b, K06 \\
\hline$\alpha$ & Coeficiente de expansão térmica & $3 \times 10^{-5} \mathrm{~K}^{-1}$ & $\mathrm{~S} 80$ \\
\hline$\kappa$ & Difusividade térmica & $10^{-6} \mathrm{~m}^{2} \mathrm{~s}^{-1}$ & $\mathrm{~S} 80$ \\
\hline$k$ & Condutividade térmica & $4,1868 \mathrm{Wm}^{-1} \mathrm{~K}^{-1}$ & $\mathrm{~S} 80$ \\
\hline$\rho_{m}$ & Densidade do manto superior & $3300 \mathrm{~kg} \mathrm{~m}^{-3}$ & CA14 \\
\hline$\rho_{\text {bas }}$ & Densidade média da crosta oceânica & $3000 \mathrm{~kg} \mathrm{~m}^{-3}$ & CA14 \\
\hline$\rho_{g r a}$ & Densidade média da crosta continental & $2900 \mathrm{~kg} \mathrm{~m}^{-3}$ & CA14 \\
\hline$\rho_{a}$ & Densidade da água & $1000 \mathrm{~kg} \mathrm{~m}^{-3}$ & CA14 \\
\hline$g$ & Aceleração da gravidade & $9,82 \mathrm{~m} \mathrm{~s}^{-2}$ & \\
\hline$R_{e}$ & Raio externo do manto & $6271 \mathrm{~km}$ & S 80 \\
\hline$R_{i}$ & Raio interno do manto & $3471 \mathrm{~km}$ & $\mathrm{~S} 80$ \\
\hline$R_{c p}$ & Raio de curvatura & $200 \mathrm{~km}$ & B86, K06 \\
\hline$h$ & Espessura da placa & $100 \mathrm{~km}$ & CH99a \\
\hline$d_{d}$ & Profundidade de desgaseificação & $60 \mathrm{~km}$ & CA14 \\
\hline$d_{\text {bas }}$ & Espessura da crosta oceânica & $6000 \mathrm{~m}$ & CA14 \\
\hline$d_{h, 0}$ & Valor nominal da profundidade de hidratação & $3000 \mathrm{~m}$ & CA14 \\
\hline$\gamma$ & Constante (ajustada) & 1,435 & \\
\hline$f_{c c}$ & Fração da superfície da Terra que é crosta continental & 0,35 & \\
\hline$f_{\text {abas }}$ & Fração de água por massa na crosta oceânica & 0,05 & MS89 \\
\hline$f_{r}$ & Fração da água que realmente adentra o manto (ajustado) & 0,4 & \\
\hline$f_{d, 0}$ & Valor nominal do parâmetro $f_{d}$ & 0,9 & CA14 \\
\hline$P_{o c}$ & Pressão de referência no fundo do oceano & $4 \times 10^{7} \mathrm{~Pa}$ & CA14 \\
\hline$\sigma$ & Dependência da pressão com a hidratação da crosta & 1 & CA14 \\
\hline$\mu$ & Dependência da pressão com a fração de desgaseificação & 1 & CA14 \\
\hline
\end{tabular}




\subsection{Modelo Atmosférico}

Como na parte térmica do modelo a parte atmosférica tem uma equação fundamental que dá o equilíbrio de energia na atmosfera. Nós seguimos Lenton e von Bloh (2001), Franck et al. (2002) e Levenson (2011) e relacionamos a temperatura efetiva, $T_{\text {ef }}$, a temperatura que o planeta teria se emitisse o mesmo tanto de energia que ele emite feito um corpo negro, com a temperatura superficial média, $T_{s}$, através de um termo de absortividade, $\mathcal{A}$, dado por um modelo de atmosfera quase-cinza (Chamberlain, 1980; Chamberlain e Hunten, 1990):

$$
\begin{aligned}
& 4 \pi R_{T}^{2} \sigma T_{e f}^{4}=\left(1-A_{p}\right) \pi R_{T}^{2} S, \\
& T_{s}^{4}=\mathcal{A} T_{e f}{ }^{4}, \\
& \mathcal{A}=\left(1+\frac{3}{4} \tau\right) .
\end{aligned}
$$

O que fornece:

$$
T_{s}=\left[\frac{\left(1-A_{p}\right) S}{4 \sigma}\left(1+\frac{3}{4} \tau\right)\right]^{\frac{1}{4}},
$$

onde $\sigma$ é a constante de Stefan-Boltzmann, $A_{p}$ é o albedo planetário efetivo, $S$ é o fluxo solar no topo da atmosfera, e $\tau$ é a profundidade óptica da atmosfera na aproximação de atmosfera quase-cinza, considerada depender, independentemente, somente da presença de $\mathrm{H}_{2} \mathrm{O}$ e $\mathrm{CO}_{2}$ :

$$
\tau=\tau\left(\mathrm{H}_{2} \mathrm{O}\right)+\tau\left(\mathrm{CO}_{2}\right)
$$

Nós assumimos que a profundidade óptica depende da pressão parcial do gás segundo uma lei de potência seguindo o procedimento de Lenton e von Bloh (2001) a partir de dados de Kasting et al. (1993). No entanto, resolvemos fazer nosso próprio ajuste em vez de utilizar o de Lenton e von Bloh (2001), porque seu ajuste é limitado ao intervalo de 0 a $40{ }^{\circ} \mathrm{C}$ e temos a intenção estudar um intervalo maior de temperaturas. Seguindo com o ajuste, temos: 


$$
\begin{aligned}
& \tau_{\mathrm{H}_{2} \mathrm{O}}=0,0278\left(P_{\mathrm{H}_{2} \mathrm{O}}\right)^{0,4079}, \\
& \tau_{\mathrm{CO}_{2}}=1,276\left(P_{\mathrm{CO}_{2}}\right)^{0,602} .
\end{aligned}
$$

A $\tau_{\mathrm{H}_{2} \mathrm{O}}$ pode ser utilizada com confiança no intervalo de 250 até $\sim 420 \mathrm{~K}$, e $\tau_{\mathrm{CO}_{2}}$, no intervalo de 0 até 2,0 bar. Mesmo assim, os ajustes parecem ser bem sensíveis ao intervalo utilizado. A pressão parcial de água na atmosfera foi estimada usando a equação de Clausius-Clapeyron:

$$
P_{\mathrm{H}_{2} \mathrm{O}}=H P_{0} \exp \left[-\frac{L_{0}}{R}\left(\frac{1}{T_{s}}-\frac{1}{T_{s, 0}}\right)\right]
$$

onde $H$ é a umidade, $P_{0}$ é uma pressão de referência para a pressão de saturação da água, e $L_{0}$ é o calor latente por mol da água. A pressão parcial de $\mathrm{CO}_{2}$ depende da equação das intempéries e da taxa de expansão do assoalho oceânico e é dada mais a frente.

A principal fonte de energia para aquecer a atmosfera é o fluxo solar. É comum usar uma aproximação simples para esse fluxo no caso terrestre, mas preferimos usar a parametrização dada em Rushby et al. (2013) com dados de Baraffe et al. (1998), porque contém também a massa da estrela ( $M_{*}$ em massas solares) como argumento além da idade $d a$ estrela $\left(t_{*}\right.$ em Ganos), permitindo que a reutilizemos no capítulo seguinte sem alterações. Ela não difere muito de outras parametrizações equivalentes na literatura, como vemos na Figura 2.4.

A curva de luminosidade distoante de Kasting et al. (1993) (baseada em cálculos de Iben Jr (1967a) e Iben Jr (1967b)) não necessariamente é um problema para o modelo deles ou para o nosso. Nós estamos interessados em, além de derivar o comportamento do sistema Terra e a habitabilidade em longas escalas de tempo, também em estimar as datas de eventos específicos. O resultado mais importante de Kasting et al. (1993) é para qual luminosidade estelar os planetas entrariam em regimes de efeito estufa úmido ou desenfreado (o limite interior da ZHC). A evolução da luminosidade da estrela só fornece uma data específica para esses eventos. Essa data seria incorreta, claro, mas não é a contribuição mais importante deles. Mantemos a curva de luminosidade de Kasting et al. (1993) na Figura 2.4 para fins de comparação e constextualização dos resultados, mas também porque, mais a frente, comparamos nossos resultados para as datas do fim da 
biosfera com dados da literatura e é preciso corrigir os resultados de Kasting et al. (1993) com relação à evolução da luminosidade solar.

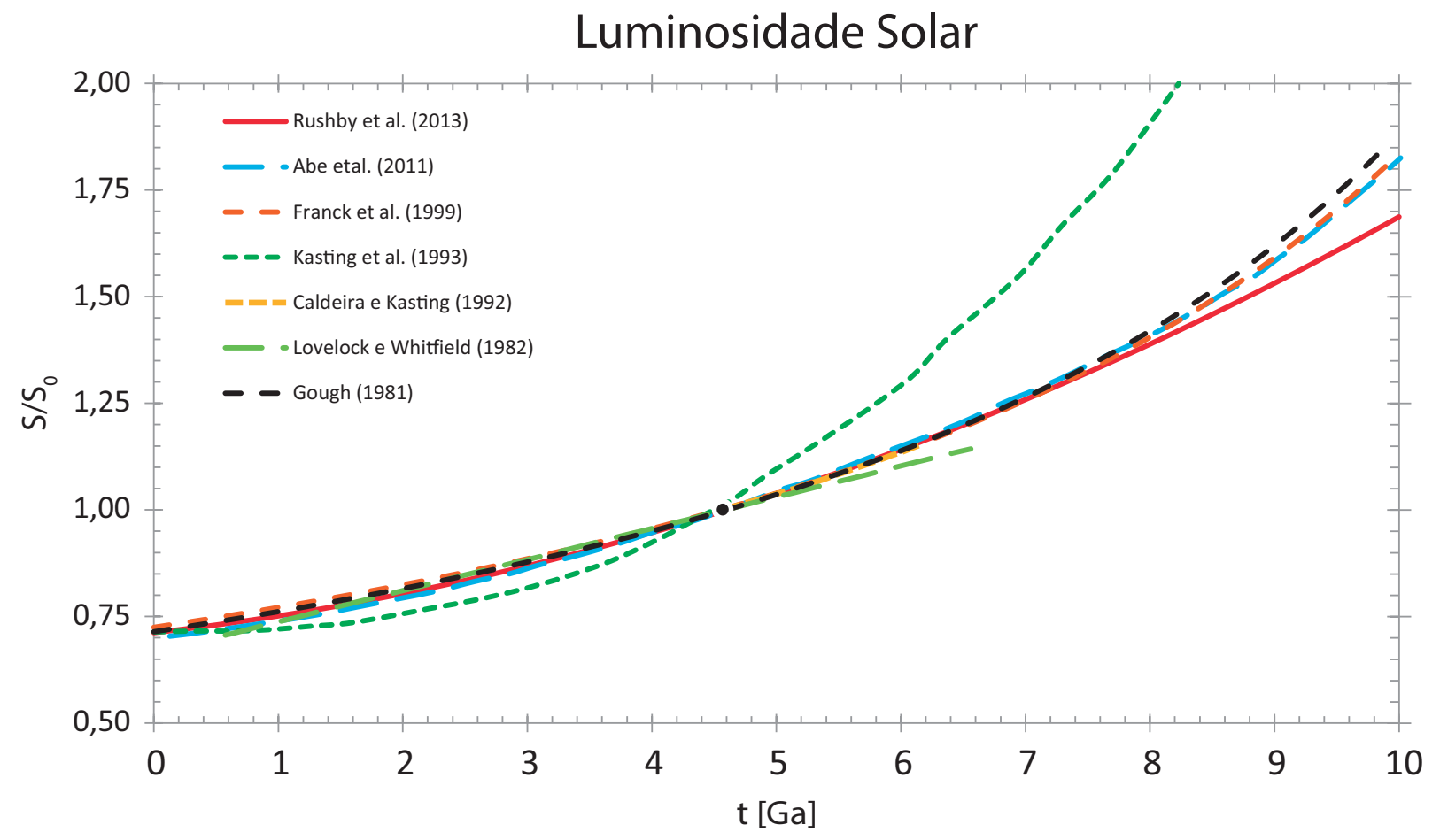

Figura 2.4: Evolução da luminosidade solar ao longo do tempo dada em trabalhos da literatura relacionados ao fim da biosfera.

Excepcionalmente neste capítulo, introduzimos uma pequena correção na forma de uma constante multiplicativa para ter com mais precisão a luminosidade solar para uma massa solar em $t=4,57 \mathrm{Ga}$ :

$$
\begin{aligned}
& L\left(M_{*}, t_{*}\right)= \\
& 1,00195 \times\left(-2,245+0,7376 \times t_{*}+16,03 \times M_{*}-0,02348 \times t_{*}{ }^{2}-4,596 \times t_{*} M_{*}\right. \\
& -44,2 \times M_{*}{ }^{2}+0,1212 \times t_{*}{ }^{2} M_{*}+10,5 \times t_{*} M_{*}{ }^{2}+59,23 \times M_{*}{ }^{3}-0,2047 \times t_{*}{ }^{2} M_{*}{ }^{2} \\
& \left.-10,43 \times t_{*} M_{*}{ }^{3}-38,59 \times M_{*}{ }^{4}+0,1132 \times t_{*}{ }^{2} M_{*}{ }^{3}+3,82 \times t_{*} M_{*}{ }^{4}+10,46 \times M_{*}{ }^{5}\right)
\end{aligned}
$$

A luminosidade solar, $L$, pode ser facilmente transformada em fluxo e então usada na equação 2.12 sabendo que para um fluxo isotrópico a relação com tal luminosidade é:

$$
S=\frac{L}{4 \pi d^{2}}
$$


onde $d$ é a distância média da Terra ao Sol, ou uma unidade astronômica. Nós utilizamos $S_{0}=1368 \mathrm{Wm}^{-2}$ para o fluxo solar atual a uma unidade astronômica, mas esse valor pode variar de 1360 até $1368 \mathrm{Wm}^{-2}$ na literatura (Kasting et al., 1993; Levenson, 2011; Wolf e Toon, 2014; Foley, 2015; Wolf et al., 2017).

\subsubsection{Albedo Planetário}

A razão entre a quantidade de energia que um corpo reflete da energia incidente sobre ele é chamada de albedo. Como essa propriedade pode depender do comprimento de onda da radiação incidente, da direção de incidência da radiação em relação à superfície do corpo, do material do qual o corpo é feito e de outras características do corpo ou da geometria entre corpo e radiação, pode ser uma propriedade difícil de ser especificada com precisão em alguns casos e que admite a existência de diferentes valores para o mesmo corpo (por exemplo, albedo de Bond e albedo geométrico). No caso da Terra, o albedo planetário (o albedo efetivo no topo da atmosfera) é o mais comumente utilizado em modelos astronômicos.

A Terra possui uma cobertura superficial de materiais com diferentes albedos (massas d'água profundas, areia, rochas nuas, pastos, florestas, cidades, gelo, neve, etc) que podem mudar com o tempo, e a atmosfera influencia bastante no albedo não só com as nuvens, mas também com os gases da atmosfera. Uma Terra coberta por nuvens ou por gelo teria um albedo muito mais alto do que uma Terra coberta por rochas nuas ou por oceanos. Dessa forma, parametrizações do albedo planetário em função do albedo superficial, da composição atmosférica e da temperatura da atmosfera (além de outras variáveis) são importantes para nosso objetivo de modelar a temperatura superficial e a habitabilidade de um planeta.

Existem na literatura diferentes curvas para o albedo planetário com relação à temperatura e outras variáveis (Figura 2.5). Elas não se alinham ou convergem muito bem e esse pode ser um ponto de imprecisão entre os diferentes modelos.

Para nosso albedo, utilizamos a parametrização dada em Williams e Kasting (1997), duas longas séries de polinômios dependentes do albedo superficial, $a_{s}$, da temperatura superficial, $T_{s}$, do cosseno do ângulo zenital, $\cos (Z)=\mu$, e da pressão parcial de $\mathrm{CO}_{2}$, $P_{\mathrm{CO}_{2}}$, que pode ser aplicada com confiança no intervalo $0<a_{s}<1,190<T_{s}<360 \mathrm{~K}$ (mas é bem comportada para além desse intervalo, podendo ser utilizada até $\sim 460 \mathrm{~K}$ ), 


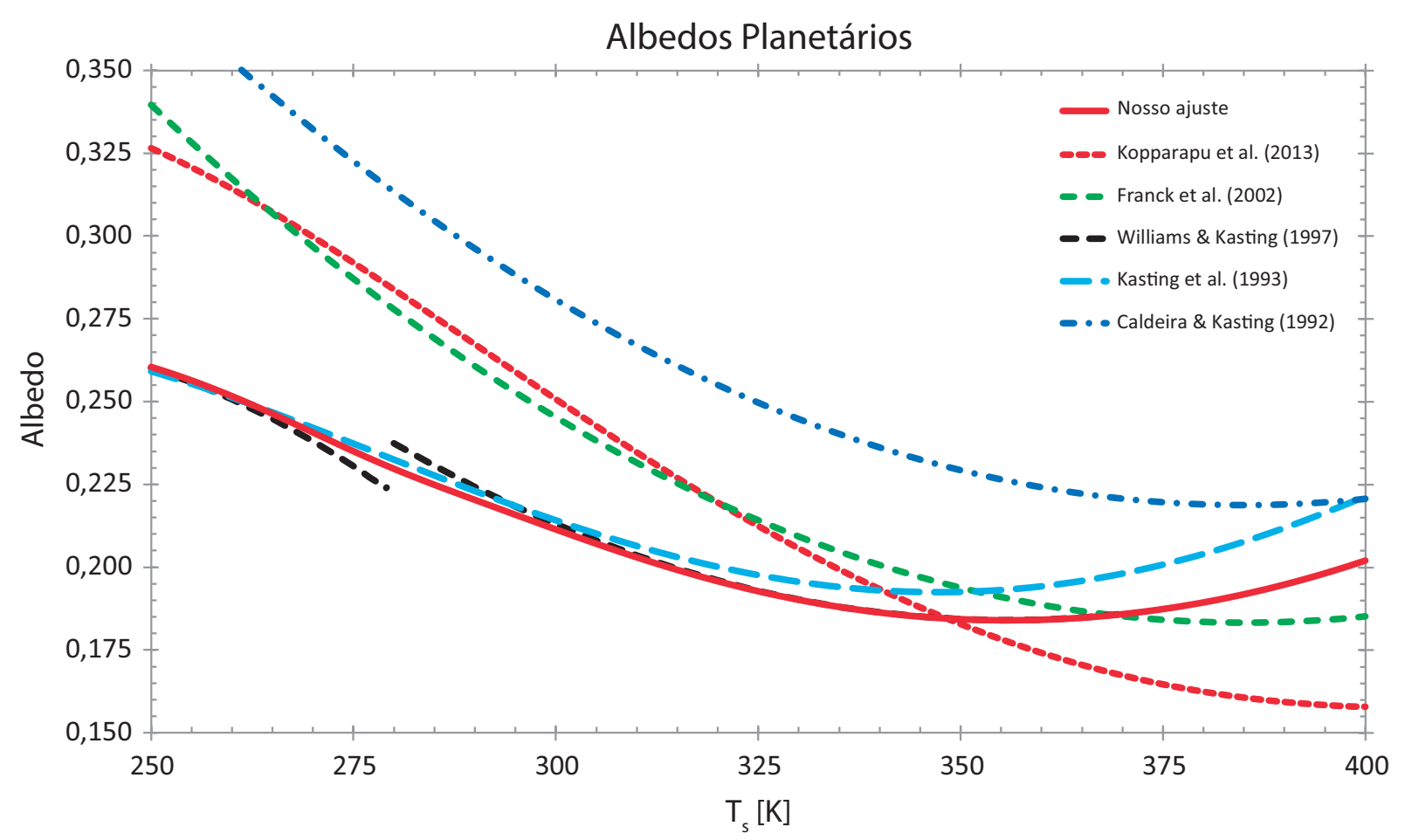

Figura 2.5: Comparação do albedo planetário dado por diferentes trabalhos na literatura. A função de Williams e Kasting (1997) é dada com parâmetros $a_{s}=0.2, Z=60^{\circ}$ e $P_{\mathrm{CO}_{2}}=0$.

$0<\mu<1$ e $10^{-5}<P_{\mathrm{CO}_{2}}<10$ bar. Para além de $\sim 460 \mathrm{~K}$ usamos o albedo planetário de Kasting et al. (1993). A parametrização original de Williams e Kasting (1997) é dividida em dois intervalos de temperatura em $280 \mathrm{~K}$ para reduzir erros. Isso cria uma descontinuidade considerável que poderia impactar nos resultados de nosso modelo com alguns saltos de albedo e, consequentemente, de temperatura. Para impedir isso conectamos os dois trechos usando duas funções sigmoides. Olhe o apêndice A.1 para mais detalhes.

A parametrização de Williams e Kasting (1997) foi concebida para um modelo 2D, com variação latitudinal e da posição angular do Sol no céu. Um jeito de contornar isso, segundo Williams e Kasting (1997), é usando $Z=60^{\circ}$, o que forneceria valores médios e mais próximos dos que nosso modelo utiliza. Alguns modelos mantêm a umidade relativa ou o albedo superficial como parâmetros livres para lidar com as limitações de modelos zerodimensionais ou unidimensionais em tratar de fenômenos inerentemente tridimensionais, como a umidade relativa ou a presença de nuvens. Nuvens podem ter efeitos tanto de aumentar o albedo e diminuir a temperatura quanto de bloquear a saída de radiação e aumentar o efeito estufa (Kasting et al., 1993). Como muitos modelos de ZHC são concebidos para explorar melhor o limite interno da ZHC, então regiões onde os planetas 
estariam mais quentes, eles usam uma atmosfera saturada, $H \rightarrow 1$. Uma atmosfera quente e saturada de água provavelmente teria muitas nuvens e a aproximação de uma atmosfera transparente, sem nuvens, não funcionaria muito bem, mas é o melhor que pode ser feito sem a inclusão de uma física exclusiva para nuvens num modelo tridimensional (Kasting et al., 1993; Kopparapu et al., 2013). O albedo superficial acaba sendo escolhido de maneira a fornecer a temperatura esperada ( $287 \mathrm{~K}$ no caso da Terra) e tem um valor $a_{s} \approx 0,2$, o que é consideravelmente mais alto do que o real albedo superficial médio de nosso planeta. O albedo planetário, por sua vez, acaba tendo um valor de $\sim 0,21$, menor do que o atual $(\sim 0,31)$ por não incluir o aumento de albedo pelo topo das nuvens brancas e o aumento de temperatura por seu efeito estufa. Por causa disso, é melhor encarar o albedo superficial e o albedo planetário aqui presentes como albedos efetivos, que incluem algo do efeito das nuvens, como se elas estivem ao nível do solo. Nós seguimos esse procedimento por termos muitas parametrizações obtidas de modelos de ZHC que fazem essas aproximações.

\subsubsection{Perda de Água}

As trocas gasosas que acontecem entre o manto e a superfície têm o potencial de mudar consideravelmente o volume do reservatório dos oceanos e impactar no clima e na habitabilidade de nosso planeta. Mas a água pode ser perdida por outras vias, como vapor, na alta atmosfera. Escape de atmosfera pode ser resumido em dar energia suficiente para as partículas da atmosfera conseguirem escapar do poço de potencial do planeta. Isso pode se dar pela energia térmica comum da atmosfera, já que o gás possui uma distribuição de temperaturas com uma cauda de partículas com bastante energia; diretamente absorvendo energia de sua estrela na alta atmosfera, principalmente no ultravioleta extremo (EUV); colisão com partículas energéticas do vento estelar; e por ganho de energia cinética pelo impacto de grandes corpos (Pierrehumbert, 2010). Nós vamos nos focar nos processos mais facilmente modeláveis e que mais provavelmente podem acometer nossa atmosfera causando perda de água, como a difusão de vapor d'água até a alta atmosfera onde fotólise e escape podem ocorrer e na absorção da energia no EUV (Abe et al., 2011). Supusemos que escape por impacto de grandes objetos, mesmo podendo ter sido relevante no passado primitivo de nosso planeta, não será relevante no futuro, com cada vez menos impactos ao longo do tempo. Já, porque a erosão da atmosfera pelo vento solar potencialmente não seria um problema, exige uma argumentação mais detalhada. 
Hoje em dia, o forte campo magnético dominantemente dipolar (em primeira aproximação) da Terra funciona como um escudo contra o vento solar, desviando suas partículas carregadas e garantindo a manutenção de nossa atmosfera (Stadelmann et al., 2010). A existência de um poderoso campo magnético planetário gerado por efeito dínamo depende da existência de um núcleo de metal líquido e está correlacionada com a massa e período de rotação do planeta (Zuluaga e Cuartas, 2012; Zuluaga et al., 2013a).

Planetas rochosos mais massivos do que a Terra podem ter maior facilidade em manter um forte campo magnético se seus períodos de rotação tiverem de 1 a 3 dias. Planetas rochosos com massas mais próximas da massa da Terra também podem desenvolver um forte campo magnético, mas este seria de curta duração para períodos de rotação muito maiores do que um dia. Só quando o período fosse da ordem de um dia que um forte campo magnético poderia ser mantido por mais do que apenas poucos bilhões de anos (Zuluaga e Cuartas, 2012).

No caso da Terra, o período de rotação tem aumento com o tempo e o núcleo externo, líquido, tem se solidificado no núcelo interno. Ambos apresentam potencial para limitar a manutenção do forte campo magnético terrestre.

O perído de rotação da Terra tem aumentado de $\sim 18$ h há 2,45 Ga para $\sim 20$ h há 0,90 Ga, até o atual de 24 h (Williams, 2000). A extrapolação dessa taxa de aumento de $\sim 2 \mathrm{~h} /$ Ga fornece um período de $\sim 28$ h daqui a 2,0 Ga e $\sim 35 \mathrm{~h}$ em 5,5 Ga. Daqui a 5,5 Ga o Sol estará saindo da sequência principal e, mesmo nesse cenário, o aumento do período de rotação seria de apenas $50 \%$ em relação ao atual.

A idade do núcleo interno não está muito bem definida, a literatura apontando valores entre 0,5 e 4,2 Ga (Biggin et al., 2015; Bono et al., 2019; Driscoll, 2019; Konôpková et al., 2016; Labrosse et al., 2001; Ohta et al., 2016; Smirnov et al., 2011; Stacey e Stacey, 1999; Tarduno et al., 2010). Sabendo o volume atual do núcleo interno $\left(7,6 \times 10^{18} \mathrm{~m}^{3}\right)$, isso fornece uma taxa de crescimento de 57,5 até $483 \mathrm{~m}^{3} \mathrm{~s}^{-1}$. Sabendo o volume do núcleo externo $\left(1,7 \times 10^{20} \mathrm{~m}^{3}\right)$, temos que o núcleo externo se solidificaria completamente no núcleo interno em um período de 11,1 até $93 \mathrm{Ga}$, o que é também mais do que o tempo de sobrevida do Sol na sequência principal. Uma estimativa mais cuidadosa pode ser feita com a taxa atual de crescimento do raio do núcleo interno de 0,5 mm/ano (Monnereau et al., 2010) e de 1,0 mm/ano (Buffett, 2000) (o equivalente a, respectivamente, 297 e $594 \mathrm{~m}^{3} \mathrm{~s}^{-1}$ ), resultando numa sobrevida para o núcleo externo de 2,26 a 4,52 Ga, um intervalo mais 
modesto, porém como será mostrado mais a frente nos resultados, mais do que o suficiente para nossos interesses.

Além do período de rotação, tectônica de placas pode estar envolvida na manutenção de um forte campo magnético (Driscoll e Bercovici, 2013; Nimmo, 2002), mas isso pode ser secundário ou depender ainda de terceiros, como a grande quantidade de água na superfície lubrificar e facilitar o movimento das placas. Como modelamos o reservatório de água superficial, podemos ter alguma ideia de quando ele estaria depletado, influenciando na habitabilidade, na tectônica de placas e, potencialmente, na intensidade do campo magnético, mas isso coincidiria ou ocorreria após o planeta ficar inabitável.

Dessa forma, em primeira aproximação, provavelmente o enfraquecimento do campo magnético terrestre, e o aumento da perda de atmosfera por vento solar, não serão um problema para a habitabilidade de nosso planeta.

A água primeiro precisa chegar na alta atmosfera para ser quebrada nos gases oxigênio e hidrogênio e ganhar energia para escapar. Mesmo que haja abundante radiação EUV para promover o escape, isso não adianta muito se não há material para escapar, e esse será um escape limitado pela difusão. O limite máximo para o fluxo por difusão, $F_{l d}$, é dado por (Abe et al., 2011):

$$
\begin{aligned}
& F_{l d}=f_{t}(i) \frac{b_{i a}\left(m_{a}-m_{i}\right) g}{k T_{\text {estrat }}}, \\
& b_{i a}=1,9 \times 10^{19}\left(\frac{T_{\text {estrat }}}{300 K}\right)^{0,75} \mathrm{~cm}^{-1} \mathrm{~s}^{-1}, \\
& T_{\text {estrat }}=167 \mathrm{~K}\left[\frac{S_{\text {eff }}\left(1-A_{p}\right)}{0,316}\right]^{0,25},
\end{aligned}
$$

onde $f_{t}(i)$ representa a razão de mistura total do elemento $i$ em todas as suas formas na homopausa, $b_{i a}$ é o coeficiente binário de difusão de $i$ no ar, $m_{a}$ e $m_{i}$ são, respectivamente, a massa de uma "molécula de ar" (a massa equivalente considerando a composição atmosférica) e a massa do considerado gás $i, k$ é a constante de Boltzmann, $T_{\text {estrat }}$ é a temperatura da estratosfera como dada em Kasting et al. (1993), e $S_{\text {eff }}$ é o fluxo solar normalizado com relação a hoje. Fizemos a aproximação de que o $\mathrm{H}_{2} \mathrm{O}$ é o portador mais importante de hidrogênio na atmosfera e, então, que $f_{t}(i)$ pode ser aproximado pela razão de mistura de água na estratosfera, $f_{\mathrm{H}_{2} \mathrm{O}}^{\text {estrat }}$ : 


$$
f_{\mathrm{H}_{2} \mathrm{O}}^{\text {estrat }}= \begin{cases}0,43411-\frac{0,43411}{1+\exp \left[0,123431\left(T_{s}-375,476 \mathrm{~K}\right)\right]}, & \text { se } T_{s}<400 \mathrm{~K}, \\ 0,896558-\frac{0,896558}{1+\exp \left[0,042219\left(T_{s}-399,142 \mathrm{~K}\right)\right]}, & \text { se } T_{s} \geqslant 400 \mathrm{~K} .\end{cases}
$$

A razão de mistura para a água na estratosfera em função da temperatura superficial foi calculada a partir das Figuras 1c e 3 de Kasting et al. (1993) (reproduzidas na Figura 2.6). Extraindo os dados das duas curvas é possível facilmente encontrar a dependência da razão de mistura com a temperatura superficial e parametrizá-la em dois intervalos de temperatura para maior precisão.
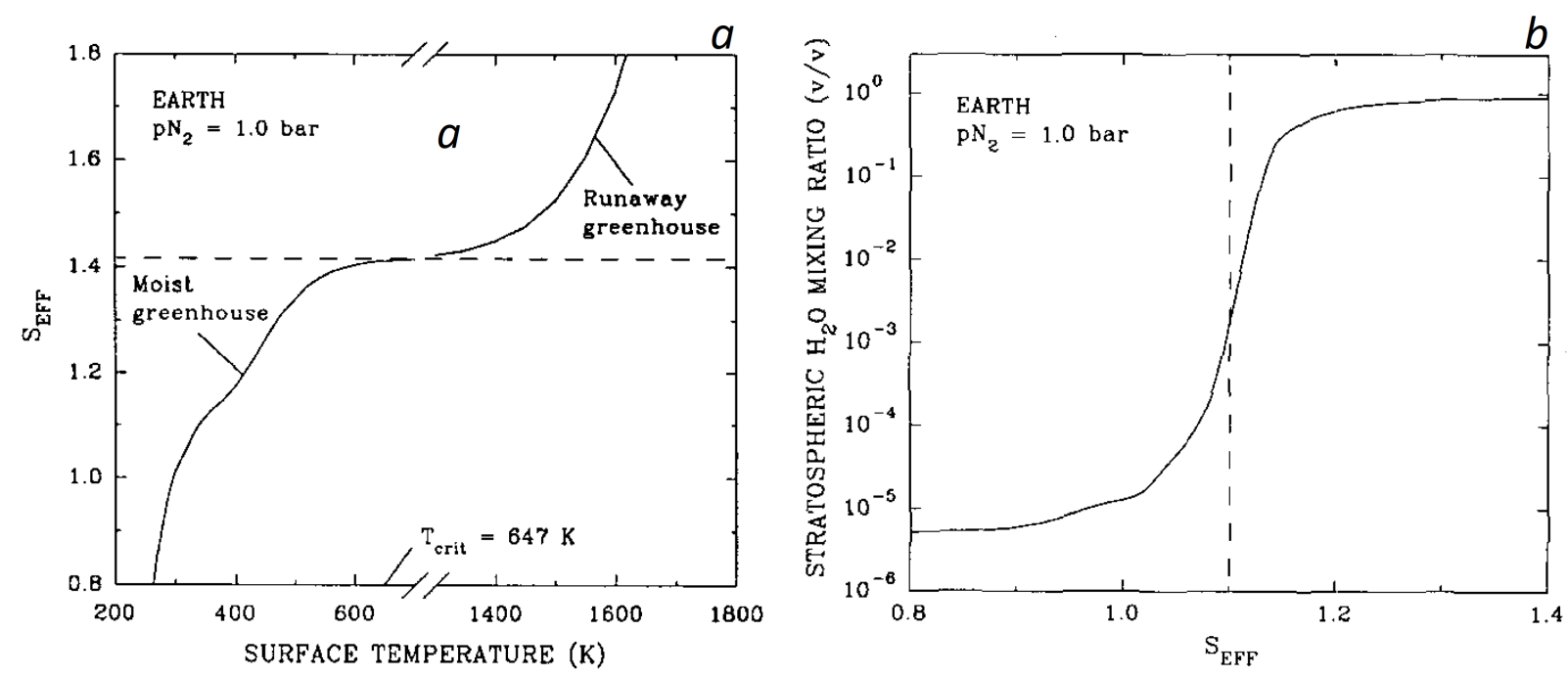

Figura 2.6: a) Fluxo solar necessário para manter uma certa temperatura superficial no limite interior da ZHC (Kasting et al., 1993). b) Variação da razão de mistura do $\mathrm{H}_{2} \mathrm{O}$ na estratosfera em relação ao fluxo solar no limite interior da ZHC (Kasting et al., 1993).

Se o gás conseguiu se difundir até a alta atmosfera, ele pode ser quebrado em seus constituintes e energizado para escapar. A eficiência desse escape então dependerá da intensidade do fluxo de radiação. O fluxo de escape limitado por energia é dado por (Watson et al., 1981; Erkaev et al., 2007; Abe et al., 2011):

$$
F_{l e}=\frac{\pi R_{T}^{3} \varepsilon S_{E U V}}{G M m_{i}}
$$

onde $R_{T}$ é o raio da Terra, $\varepsilon$ é um coeficiente de eficiência para o aquecimento do gás pelo fluxo EUV, $S_{E U V}$, do Sol, $G$ é a constante da gravitação universal, e $M$ é a massa da Terra. O coeficiente de eficiência tem um valor que pode mudar com a região do espectro e com o 
tempo, mas é comum ser fixado no intervalo de 0,1 até 0,6 na literatura, e frequentemente tem o conservador valor de 0,2 (Watson et al., 1981; Penz et al., 2008; Lammer et al., 2009; Kuramoto et al., 2013; Zahnle e Catling, 2017). Usaremos esse valor em nosso modelo básico.

A equação 2.20 é uma aproximação da equação derivada em Erkaev et al. (2007) para o caso de um planeta distante de sua estrela e com uma atmosfera pouco expandida devido às temperaturas não muito altas (que é o caso da Terra). Em alguns trabalhos (como Abe et al. (2011)) pode aparecer um fator 4 na frente do lado direito da equação 2.20. Isso parece ser devido às unidades de $F_{l e}$ e à normalização de $S_{E U V}$, porque Watson et al. (1981) não apresenta essa equação nem com fator 4 e nem com o $\pi$, mas usa o $S_{E U V}$ que o planeta todo recebe (um disco de área $\left.\pi R_{T}{ }^{2}\right)$ normalizado pela área do planeta $\left(4 \pi R_{T}{ }^{2}\right)$ e usa o fluxo $F_{l e}$ por unidade de ângulo sólido. Se integrarmos $F_{l e}$ por unidade de ângulo sólido ao longo da esfera, teremos um fator $4 \pi$, e se usarmos o fluxo estelar (e não o total normalizado pela área do planeta), teremos um fator $1 / 4$, então sobrando somente um fator $\pi$.

O exato intervalo do espectro do qual constituem os fótons que vão dissociar as moléculas de $\mathrm{H}_{2} \mathrm{O}$ e, absorvidas pelo hidrogênio, promover seu escape térmico, não é muito bem padronizado na literatura, além dos acrônimos usados para designá-lo não serem usados consistentemente. Neste trabalho, usamos o ultravioleta extremo (EUV) no intervalo de 10 até $120 \mathrm{~nm}$ mais a linha Lyman-alfa em 121,6 nm. Para o Sol hoje o fluxo próximo desse intervalo está ao redor da unidade em $\mathrm{erg} \mathrm{cm}^{-2} \mathrm{~s}^{-1}$, mas diferentes trabalhos usaram aproximações que variaram de 0,85 até 6,9 $\mathrm{erg} \mathrm{cm}^{-2} \mathrm{~s}^{-1}$ (Watson et al., 1981; Ribas et al., 2005; Baraffe et al., 2004; Penz et al., 2008; Penz e Micela, 2008; Lammer et al., 2009; Kuramoto et al., 2013). Uma robusta aproximação para o fluxo solar nesse intervalo é dada por Ribas et al. (2005):

$$
S_{E U V}(t)=29,7 \times t_{*}{ }^{-1,23}+19,2 \times t_{*}{ }^{-0,72},
$$

onde $t_{*}$ é a idade do Sol em Ga, $S_{E U V}(t)$ é dado em erg $\mathrm{cm}^{-2} \mathrm{~s}^{-1}$ e estabiliza num platô para $t_{*}<0,1 \mathrm{Ga}$. O primeiro termo do lado direito corresponde ao intervalo de 10 até $120 \mathrm{~nm}$, e o segundo termo corresponde à linha Lyman-alfa.

O fator limitante para o limite de escape pode ser a difusão (insuficiente gás para apro- 
veitar toda a radiação) ou a energia (radiação insuficiente para dissociar e aquecer o gás). Então escolhemos sempre o menor entre os dois limites a qualquer tempo: $\min \left[F_{l d}, F_{l e}\right]$.

Estamos lidando com casos limites de escape mesmo usando o coeficiente de eficiência e estamos considerando que a água que chega à alta atmosfera será facilmente dissociada ao ponto da razão de mistura de água ser a de hidrogênio sem reação de volta com o oxigênio, que não será perdido, mas irá reagir com as rochas. Então estamos sempre no caso de maior perda possível de água e de limite inferior, mais conservador, para a habitabilidade.

\subsection{Intemperismo e Influência Biológica}

Aqui voltamos ao ciclo do carbono estabilizante climático em grandes escalas de tempo mencionado anteriormente, mas de maneira mais cuidadosa.

$\mathrm{O} \mathrm{CO}_{2}$ presente na atmosfera é parcialmente removido ao reagir com a água da chuva ou no solo formando ácido carbônico $\left(\mathrm{H}_{2} \mathrm{CO}_{3}\right)$ que, embora seja um ácido fraco, ao longo de longas escalas de tempo, dissolve rochas formando íons. No caso específico do silicato de cálcio $\left(\mathrm{CaSiO}_{3}\right)$ são formados os íons $\mathrm{Ca}^{2+}$ e $\mathrm{HCO}_{3}^{-}$e sílica $\left(\mathrm{SiO}_{2}\right)$ (Berner, 2004):

$$
2 \mathrm{CO}_{2}+\mathrm{H}_{2} \mathrm{O}+\mathrm{CaSiO}_{3} \longrightarrow \mathrm{Ca}^{2+}+2 \mathrm{HCO}_{3}^{-}+\mathrm{SiO}_{2}
$$

Essas substâncias escoam para os oceanos através dos rios. Nos oceanos, os íons são precipitados (hoje, principalmente por vias biológicas) em carbonato de cálcio $\left(\mathrm{CaCO}_{3}\right) \mathrm{e}$ um dos dois $\mathrm{CO}_{2}$ iniciais é devolvido à atmosfera:

$$
\mathrm{Ca}^{2+}+2 \mathrm{HCO}_{3}^{-} \longrightarrow \mathrm{CaCO}_{3}+\mathrm{CO}_{2}+\mathrm{H}_{2} \mathrm{O}
$$

O carbonato de cálcio e a sílica são, então, enterrados em sedimentos marinhas no assoalho oceânico. Em zonas de subducção, esse material é levado em direção ao manto, onde, pela ação da pressão e calor, o carbonato de cálcio e a sílica reagem metamorficamente gerando a rocha inicial de silicato de cálcio e o dióxido de carbono:

$$
\mathrm{CaCO}_{3}+\mathrm{SiO}_{2} \longrightarrow \mathrm{CaSiO}_{3}+\mathrm{CO}_{2}
$$

Daqui, o $\mathrm{CO}_{2}$ retorna para a atmosfera por atividade vulcânica ou pelas dorsais oceânicas, fechando o ciclo. A equação resultante desses processos pode ser escrita como (Berner, 
1990):

$$
\mathrm{CO}_{2}+\mathrm{CaSiO}_{3} \rightleftharpoons \mathrm{CaCO}_{3}+\mathrm{SiO}_{2}
$$

Esse processo pode se repetir para outras rochas silicatas, com $\mathrm{Mg}$, $\mathrm{K}$ e $\mathrm{Na}$, mas são os silicatos de $\mathrm{Ca}$ e $\mathrm{Mg}$ que importam no ciclo, por, de fato, retirarem algum $\mathrm{CO}_{2}$ da atmosfera no processo de intemperismo sem devolvê-lo todo para atmosfera ao formarem novos silcatos nos sedimentos (como acontece Na e K) (Berner, 2004).

O ciclo depende fortemente da ação do intemperismo continental, $W$, usando uma variação da formulação original de Walker et al. (1981) baseada na cinética de reações de intemperismo entre $\mathrm{CO}_{2}$ e rochas silicatas e com estimativas do escoamento do material para o oceano:

$$
\frac{W}{W_{0}}=B_{f}\left(\frac{P_{\mathrm{H}_{2} \mathrm{O}}}{P_{\mathrm{H}_{2} \mathrm{O}}^{0}}\right)^{a}\left(\frac{P_{\mathrm{CO}_{2}}}{P_{\mathrm{CO}_{2}}^{0}}\right)^{b} \exp \left[-\frac{E_{a}}{R}\left(\frac{1}{T_{s}}-\frac{1}{T_{s a t}}\right)\right],
$$

onde $B_{f}$ é uma variável relacionada à eficiência do intemperismo no caso de uma Terra abiótica ou sem plantas vasculares, $a$ e $b$ expressam a dependência das leis de potência, $E_{a}$ é a energia de ativação das reações de intemperismo, $T_{\text {sat }}$ é a temperatura de saturação, e o índice 0 indica valores para a Terra atual, a menos do caso de $P_{\mathrm{CO}_{2}}$, onde indica o valor pré-industrial de $\sim 0,28$ mbar. Demais parâmetros estão listados na Tabela 2.3. A expressão original de Walker et al. (1981) incorpora a dependência com a pressão parcial de $\mathrm{H}_{2} \mathrm{O}$ (e potencialmente com a frequência de chuva e maior intemperismo) na exponencial do lado direito da equação 2.26, porque, remetendo à equação 2.15, a $P_{\mathrm{H}_{2} \mathrm{O}}$ é comumente dada como uma exponencial que depende do inverso da temperatura. É frequente na literatura a simplificação do argumento da exponencial na equação 2.26 por $\left(T_{s a t}-T_{s}\right) / T_{U}$, onde $T_{U}$ é uma constante resultante de colocar $1 / T_{s}$ e $1 / T_{\text {sat }}$ na mesma base e supondo que a $T_{s}$ do denominador não vai se distanciar muito da temperatura de saturação $\left(T_{s} \sim T_{\text {sat }} \rightarrow\right.$ $\left.T_{s} T_{\text {sat }} \sim T_{\text {sat }}^{2}\right)$ e incorporando as constantes $E / R$. Nós não fizemos essas simplificações porque preferimos uma formulação em que as dependências ficassem mais claras.

Algumas vezes, há um termo relacionado com a área seca (continental) exposta para a ação de intemperismo, e a lógica de existência desse termo é que quanto mais área continental houvesse mais área de reação o $\mathrm{CO}_{2}$ teria e mais intenso o intemperismo ocorreria. Nós não incluímos esse termo, porque Abbot et al. (2012) indicam que o comportamento 
do intemperismo não depende fortemente da área seca para planetas parcialmente cobertos por oceanos (como a Terra) e que mesmo uma pequena área seca pode ser suficiente para manter o ciclo do carbono ao sofrer intemperismo de maneira mais intensa.

A variável $B_{f}$ é uma tentativa de corrigir o efeito que plantas vasculares podem ter no intemperismo desde seu aparecimento 400 milhões de anos atrás. Walker et al. (1981) comentam que o escoamento de material de intemperismo hoje pode ser maior do que o esperado numa Terra abiótica porque plantas vasculares e micróbios especializados poderiam segurar solo fofo e rico em material orgânico, aumentando a área de contato entre os reagentes e aumentando a concentração de $\mathrm{CO}_{2}$ no solo. Schwartzman e Volk (1989) indicam que o intemperismo poderia ser 10, 100 ou até 1000 vezes mais intenso hoje do que no passado. Nós preferimos partir de um valor mais modesto, com somente o dobro de eficiência nos dias atuais. E, do jeito modelado, $B_{f}$ tem valor 1 hoje em dia e um valor menor no passado como explicado logo mais a frente.

Tabela 2.3 - Parâmetros e constantes do modelo de intemperismo e de biosfera.

\begin{tabular}{llll}
\hline Símbolo & \multicolumn{1}{c}{ Descrição } & \multicolumn{1}{c}{ Valor } & \multicolumn{1}{c}{ Referência } \\
\hline$H$ & Umidade relativa média & 1 & \\
$P_{0}$ & Pressão de referência pra curva de vapor de pressão da água & $610 \mathrm{~Pa}$ & Kasting et al. (1984) \\
$L_{0}$ & Calor latente por mol de água & $43655 \mathrm{Jmol}^{-1}$ & \\
$a_{s}$ & Albedo superficial & 0,192 & \\
$a$ & Exponencial de intempéries de $P_{\mathrm{H}_{2} \mathrm{O}}$ & 0,65 & Pierrehumbert (2010) \\
$b$ & Exponencial de intempéries de $P_{\mathrm{CO}_{2}}$ & 0,5 & Pierrehumbert (2010) \\
$E_{a}$ & Energia de ativação das reações de intemperismo & $63 \mathrm{~kJ} \mathrm{~mol}^{-1}$ & West et al. (2005) \\
$T_{\text {sat }}$ & Temperatura de saturação & $287 \mathrm{~K}$ & \\
$T_{\text {prod }}$ & Temperatura da produtividade máxima & $25{ }^{\circ} \mathrm{C}$ & \\
$P_{\text {min }}$ & Pressão parcial mínima de $\mathrm{CO}{ }_{2}$ que a biosfera aguenta & $0,01 \mathrm{mbar}^{2}$ & \\
$P_{1 / 2}$ & $P_{\mathrm{CO}_{2}}$ onde a produtividade tem metade do valor máximo & $0,29 \mathrm{mbar}$ & \\
$t_{\text {vasc }}$ & Tempo $t$ de aparecimento das plantas vasculares & $4,1 \mathrm{Ga}$ & \\
$B$ & Fator de amortecimento do intemperismo & 2 & \\
\hline
\end{tabular}

Basicamente, a equação 2.26 diz que o intemperismo aumenta se a temperatura aumenta, pois temperaturas mais altas promovem as reações com o ácido carbônico, o que é expresso no termo exponencial. Temperaturas altas também aumentam a pressão parcial de $\mathrm{H}_{2} \mathrm{O}$ promovendo, potencialmente, mais chuvas e mais contato entre os reagentes e mais intemperismo. O intemperismo aumenta também com uma potência da pressão parcial 
de $\mathrm{CO}_{2}$ porque há mais reagente para todo o processo. Os valores de $a$ e $b$ variam consideravelmente na literatura, indo de, respectivamente, 0,3 até 1,0 e de 0,25 até 1,0. Nós preferimos usar os valores mais comuns de, respectivamente, 0,65 e 0,5 (Pierrehumbert, 2010).

Walker et al. (1981) também indicam um jeito simples de obter $P_{\mathrm{CO}_{2}}$ supondo que a taxa de intemperismo de silicatos seria aproximadamente proporcional à taxa de liberação de $\mathrm{CO}_{2}$ do manto, que é por sua vez proporcional ao $S_{r}$, mantendo um equilíbrio quanto ao fluxo de carbono no sistema atmosfera-oceanos-manto. O que fazemos então é igualar $W / W_{0}$ a $S_{r} / S_{r}^{0}$ e isolar $P_{\mathrm{CO}_{2}}$, obtendo:

$$
P_{\mathrm{CO}_{2}}=P_{\mathrm{CO}_{2}}^{0}\left\{\left(\frac{1}{B_{f}}\right)\left(\frac{S_{r}}{S_{r}^{0}}\right)\left(\frac{P_{\mathrm{H}_{2} \mathrm{O}}}{P_{\mathrm{H}_{2} \mathrm{O}}^{0}}\right)^{-a} \exp \left[\frac{E_{a}}{R}\left(\frac{1}{T_{s}}-\frac{1}{T_{\text {sat }}}\right)\right]\right\}^{\frac{1}{b}} .
$$

A equação acima é bem mais simples do que seguir o fluxo de carbono em todas as suas formas por vários reservatórios e diminui a responsabilidade de escolher constantes e parâmetros que podem ter grandes incertezas relacionadas, mas depende da condição de equilíbrio do fluxo de carbono para atmosfera e fora dela. Tentamos assegurar essa condição usando passos temporais no modelo maiores do que o necessário para estabilizar o sistema quanto a flutuações em $T_{s}, S_{r}$ e $P_{\mathrm{CO}_{2}}$ com um passo $\gtrsim 10^{5}$ anos (Volk, 1987; Colbourn et al., 2015). Essa condição pode ser quebrada se, por exemplo, a área seca disponível para intemperismo for para 0 ou para 1, porque, no primeiro caso, não haveria terra alguma, e, no segundo caso, não haveria água para lubrificar as placas e manter a tectônica de placas e a habitabilidade do planeta. Como acompanhamos a quantidade de água na superfície, podemos sempre verificar essa condição.

O fator $B_{f}$ depende de uma partição da biosfera e seu efeito no intemperismo. Para isso, seguimos Volk (1987) com um modelo simples de produtividade biológica primária, $\Pi$, a taxa de geração de biomassa, dependente apenas de $T_{s}, P_{\mathrm{CO}_{2}}$ e $t$ : 


$$
\begin{aligned}
B_{f} & =\frac{\Pi}{\Pi_{0}}\left(1-\frac{1}{B}\right)+\frac{1}{B}, \\
\frac{\Pi}{\Pi_{0}} & =\Pi_{T} \times \Pi_{P} \times \Pi_{t}, \\
\Pi_{T} & =1-\left[\frac{\left(T_{s}-273 K\right)-T_{\text {prod }}}{T_{\text {prod }}}\right]^{2}, \\
\Pi_{P} & =\frac{P_{\mathrm{CO}_{2}}-P_{\text {min }}}{P_{1 / 2}+\left(P_{\mathrm{CO}_{2}}-P_{\text {min }}\right)}, \\
\Pi_{t} & =\frac{1}{1+\exp \left[-50\left(t-t_{\text {vasc }}\right)\right]},
\end{aligned}
$$

onde $\Pi_{0}$ é o valor atual para a produtividade, $T_{\text {prod }}$ é a temperatura em que a produtividade é máxima, $P_{\min }$ é a pressão parcial de $\mathrm{CO}_{2}$ mínima que a biosfera consegue resistir, $P_{1 / 2}$ é a pressão parcial de $\mathrm{CO}_{2}$ em que a produtividade tem metade do valor máximo, $t_{\text {vasc }}$ é o momento, partindo de $t=0$, em que as plantas vasculares apareceram, e $B$ é uma constante para o máximo de eficiência do intemperismo atual em relação ao passado.

Por clareza dividimos a produtividade em três componentes. A primeira modela a dependência com a temperatura com uma forma parabólica com raízes em 273 e $323 \mathrm{~K}$ $\left(0\right.$ e $50{ }^{\circ} \mathrm{C}$ ) e um máximo em $T_{\text {prod. }}$. A segunda trata da dependência com $P_{\mathrm{CO}_{2}}$, indo de 0 em $P_{\text {min }}$ até 1 para pressões maiores. O último é uma função sigmoide que zera a produtividade antes de $\sim t_{\text {vasc }}$. A produtividade de toda a biosfera seria não zero antes de $t_{\text {vasc }}$, mas estamos modelando somente uma parte da biosfera e uma parte de seu potencial efeito no planeta. Por esse motivo que a temperatura máxima que nossa biosfera modelada suporta é $323 \mathrm{~K}$, enquanto usamos $373 \mathrm{~K}$ para estimar a habitabilidade do planeta inteiro e a duração da biosfera na Terra.

A produção primária dos organismos autótrofos costuma suportar os ecossistemas. Grande parte dos autótrofos realiza fotossíntese e adquire seu carbono do $\mathrm{CO}_{2}$ da atmosfera. De maneira análoga a como sufocaríamos em um ambiente com baixo teor de $\mathrm{O}_{2}$, fotossintetizantes podem ser incapazes de fixar carbono se a pressão parcial atmosférica de $\mathrm{CO}_{2}$ cair abaixo de certos níveis, basicamente morrendo de fome. Os níveis de $\mathrm{CO}_{2}$ na atmosfera variaram na história do planeta e podem continuar a variar no futuro, podendo haver momentos onde eles estariam baixos demais, afetando os organismos fotossintetizantes, os ecossistemas e a biosfera. Como o mecanismo de fotossíntese (as cadeias químicas e 
as estruturas físicas) usado difere nos organismos, esse limite inferior pode variar bastante de espécie para espécie.

Plantas terrestres geralmente têm o mecanismo de fotossíntese dividido nos tipos C3, C4 e CAM, sendo C3 o mais comum, presente em 95\% das espécies de plantas terrestres, seguido por CAM em 4\% e C3 em 1\% (Bowes, 1993). Fotossíntese C4 é mais eficiente em climas úmidos e frios e alguns exemplos são arroz, trigo, soja e todas as árvores. C4 é um processo com menor perda de água e com funcionamento até níveis de $\mathrm{CO}_{2}$ mais baixos do que de plantas C3. O mecanismo C4 evoluiu independentemente mais de 45 vezes em 19 famílias de angiospermas nos últimos $\sim 30 \mathrm{Ma}$, coincidindo com períodos globais de aridificação e queda nos níveis de $\mathrm{CO}_{2}$ (Sage, 2004), talvez, por causa disso, sendo mais eficiente em ambientes quentes e ensolarados. Alguns exemplos são a cana-de-açúcar e o milho. CAM é um processo mais comum em plantas que vivem em ambientes muito quentes e secos, sendo muito eficiente no uso de água. Exemplos são cactos e suculentas, mas existem exemplos também em algumas plantas aquáticas, onde o fator limitante não é a água, mas o $\mathrm{CO}_{2}$ (Keeley e Busch, 1984; Keeley, 1998).

Na literatura relacionada ao fim da biosfera e habitabiliade de nosso planeta, as plantas C3 e C4 (ou mais especificamente seus limites de $P_{\mathrm{CO}_{2}}$ para fotossíntese) são tradicionalmente utilizados para estimar o fim da biosfera, ou de uma grande parte considerável dela, por falta de carbono (Lovelock e Whitfield, 1982; Caldeira e Kasting, 1992). Nós utilizamos esses dois limites de pressão mínima de $\mathrm{CO}_{2}$ : o de 0,15 mbar de plantas C3 (Lovelock e Whitfield, 1982; Caldeira e Kasting, 1992; Lenton, 200) e de 0,01 mbar para plantas C4 (Caldeira e Kasting, 1992; Franck et al., 2000a,b, 2006). Mas esses limites não são realmente insuperáveis. Os níveis de $\mathrm{CO}_{2}$ na atmosfera vêm caindo ao longo da história da Terra e estamos próximos do limite para plantas C3. Plantas C4 (e CAM), mais eficientes, poderiam se aproveitar disso no futuro e ganhar terreno mais tradicionalmente pertencente às plantas C3 ao se deselvolverem em árvores e poderem formar florestas (Sage, 2004). Plantas C4 e CAM ou outras plantas poderiam se adaptar, assim como novos organismos poderiam surgir para sobreviver nos ambientes menos hospitaleiros do futuro. Então esses limites de $P_{\mathrm{CO}_{2}}$ devem ser melhor entendidos como fatores limitantes, dificuldades para a sobrevivência da biosfera, não como paredes intransponíveis. São marcadores de tempos menos habitáveis na história do planeta. 


\subsection{Resolvendo o Modelo}

Todas as equações interdependentes acima foram solucionadas numericamente iterativamente em um programa escrito em $\mathrm{C}$ até a convergência da temperatura superficial com a variação entre iterações atingindo um $\Delta T_{s}$ predefinido ou o número de iterações atingindo um limite superior de iterações (indicando a não convergência), o que ocorresse primeiro. Talvez fosse mais razoável mover a variável tempo para trás no programa ao estudar o passado do planeta, já que saímos de um estado mais bem conhecido, o presente. Preferimos o contrário, sair do passado em direção do presente. Isso provoca um pouco mais de trabalho ao selecionar os parâmetros iniciais para acertar o estado atual partindo de outro estado consideravelmente diferente. Decidimos fazer assim porque estamos interessados na habitabilidade de nosso planeta especificamente nesse capítulo, mas desejamos utilizar o mesmo modelo para planetas diferentes da Terra e, nesse caso, faria mais sentido realmente mover a variável tempo para frente ininterruptamente, já que não há estado bem conhecido algum do qual partir e facilitar o trabalho.

Nós consideramos o presente como $t=4,50 \mathrm{Ga}$, o que é menos do que a idade de nosso planeta e do Sistema Solar, estimado em 4,57 Ga (Amelin et al., 2002; Baker et al., 2005). Isso foi porque achamos que o modelo dificilmente modelaria bem o período de acresção da formação de nosso planeta, a colisão da proto-Terra com Theia formando a Lua e o oceano de lava, que, provavelmente, ocorreu durante os primeiros 50 a $100 \mathrm{Ma}$ da formação do Sistema Solar (Halliday, 2000). A equação 2.16 leva isso em conta com um deslocamento de 70 Ma usando a idade da estrela (o Sol no caso) com $t_{*}$, enquanto o resto do modelo usa a idade do planeta com $t$.

As larguras de confiança em $T_{s}$ e $P_{\mathrm{CO}_{2}}$ foram calculadas considerando que $T_{s}$ e $P_{\mathrm{CO}_{2}}$ variaram consideravelmente no último 1-2 milhões de anos e que qualquer um dos valores no intervalo de variação poderia ser usado como valor representativo do presente, já que um ou dois milhões de anos é um piscar de olhos geológico ou astronômico. A variação em temperatura foi estimada em $2{ }^{\circ} \mathrm{C}$ para mais e $5{ }^{\circ} \mathrm{C}$ para menos, enquanto a variação em concentração de $\mathrm{CO}_{2}$ na atmosfera foi estimada em 110 ppmv para menos (Hansen et al., 2013; Foster et al., 2017). 


\subsection{Resultados Parciais e Discussão}

\subsubsection{Evolução Térmica}

A produção inicial total de energia por isótopos radioativos, $H(0)$, é basicamente o dobro do fluxo de energia do manto, $Q(0)$, o que claramente leva ao acúmulo de energia e ao aquecimento do manto. Isso é percebido na temperatura do manto e na taxa de variação da temperatura do manto, primeiramente positiva e, depois, negativa. A temperatura do manto ao longo do tempo parece de acordo com os dados, embora a flutuação e barras de erro deem bastante espaço para variações. Modelos como McGovern e Schubert (1989) preveem um tempo de relaxamento de $\sim 1$ Ga para a temperatura do manto, de maneira que diferentes condições iniciais coincidiriam com o mesmo estado atual e o sistema se "esqueceria" de suas condições iniciais, o que dificultaria conhecer por modelos algo do estado inicial. Nosso modelo é algo sensível às condições iniciais e foi preciso escolher a temperatura potencial inicial $\left(1550{ }^{\circ} \mathrm{C}\right)$ de maneira a, com o fluxo de calor convectivo atual, fornecer uma temperatura do manto dentro do esperado. A comparação de resultados do modelo para o tempo atual com os dados da literatura são apresentados na Tabela 2.4.

Tabela 2.4 - Comparação de resultados de nosso modelo com dados da literatura para o tempo atual.

\begin{tabular}{ccc|cc}
\hline Símbolo & Nome & Valor & \multicolumn{2}{|c}{ Valor de Referência } \\
\hline$d T_{m} / d t$ & Taxa média de resfriamento secular & $114 \mathrm{~K} \mathrm{Ga}^{-1}$ & $70-130 \mathrm{~K} \mathrm{Ga}^{-1}$ & Arevalo Jr et al. (2009) \\
$U r$ & Razão de Urey & 0,354 & $\sim 0,34$ & Arevalo Jr et al. (2009) \\
$q$ & Fluxo de calor convectivo & $76 \mathrm{~mW} \mathrm{~m}^{-2}$ & $74 \mathrm{~mW} \mathrm{~m}^{-2}$ & Korenaga (2008) \\
$S_{r}$ & Taxa de expansão do assoalho oceânico & $0,100 \mathrm{~m}^{2} \mathrm{~s}^{-1}$ & $0,1077 \mathrm{~m}^{2} \mathrm{~s}^{-1}$ & Rowley (2002) \\
$T_{m}$ & Temperatura potencial do manto & $1328{ }^{\circ} \mathrm{C}$ & $1275-1375{ }^{\circ} \mathrm{C}$ & Katsura et al. (2004) \\
\hline
\end{tabular}

Com a exaustão de ${ }^{235} \mathrm{U}$ e depois de ${ }^{40} \mathrm{~K}$, com suas meia-vidas mais curtas, $H$ cai rapidamente. Hoje em dia estaríamos passando por uma transição onde a energia do decaimento de ${ }^{232} \mathrm{Th}$, com longa meia-vida, passaria a dominar a geração de energia no lugar de ${ }^{238} \mathrm{U}$, e teria um papel importante em manter a geração de energia no manto no futuro. Isso criou a expectativa de que conseguiríamos manter o fluxo convectivo alto por um pouco mais tempo do que comparado com outros modelos, e então também manter uma maior taxa de expansão do assoalho oceânico e uma maior pressão de $\mathrm{CO}_{2}$ por mais tempo. 
No entanto, como consideramos que parte do material radiogênico do manto é concentrada na crosta continental conforme ela cresce, nossos resultados não se diferenciam muito do de outros modelos a menos da maior estabilidade no fluxo de energia.

\section{Evolução Térmica da Terra}
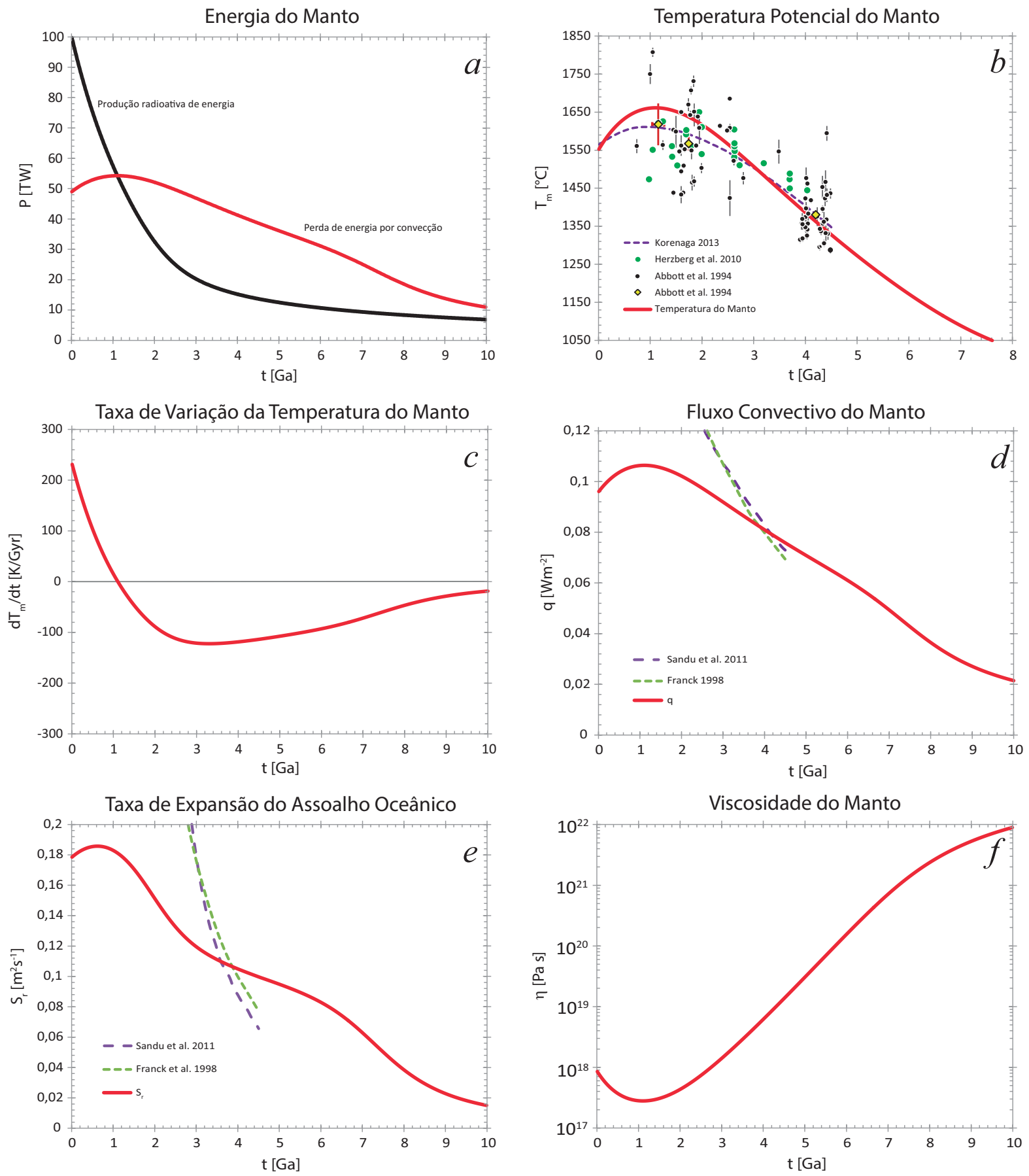

Figura 2.7: Principais resultados do modelo de evolução térmica do manto terrestre.

Nosso fluxo convectivo por área, $q$, e a taxa de expansão do assoalho oceânico, $S_{r}$, 
variam algo como um fator 2 nos últimos 4,5 Ga, bem menos (então mais constantes) do que os modelos clássicos (Franck, 1998; Sandu et al., 2011) que variam algo como um fator 10 ou 20. Isso se deve à diferente parametrização para o fluxo convectivo que utilizamos, menos sensível à temperatura do manto. Conforme o manto esfria e sua temperatura cai, sua viscosidade aumenta, contribuindo para a queda no fluxo convectivo de energia para a superfície. Nesse ponto, o manto perderia energia mais lentamente, como evidenciado em $d T_{m} / d t$ tender a zero inferiormente. Esse comportamento é mais sucintamente expressado pela razão de Urey, $U r$, e pelo número de Rayleigh, $R a$.

A razão de Urey é definida como a razão da produção energética radioativa pelo perda de energia por convecção do manto: $U r=H / Q$. Um valor acima de 1 indica um ganho resultante de energia pelo manto (aquecimento), enquanto um valor menor do que 1 indica perda de energia pelo manto (resfriamento). Um valor 1 indica o equilíbrio térmico. Hoje, $t=4,5 \mathrm{Ga}$, nosso modelo fornece $U r=0,35$ (Tabela 2.4 e Figura 2.8a). Isso é consideravelmente menor do que $\sim 0,8$, o valor dado pela maioria dos modelos convectivos convencionais (Schubert et al., 1980; Davies, 1980; Richter, 1984; McGovern e Schubert, 1989; Franck e Bounama, 1995; Sandu et al., 2011). Mas isso não é um mau sinal, pois está compatível com o valor 0,21-0,49 do esperado pelas estimativas geoquímicas (Arevalo Jr et al., 2009) e de modelos parametrizados mais recentes (Korenaga, 2006; Lenardic et al., 2011; Korenaga, 2012).
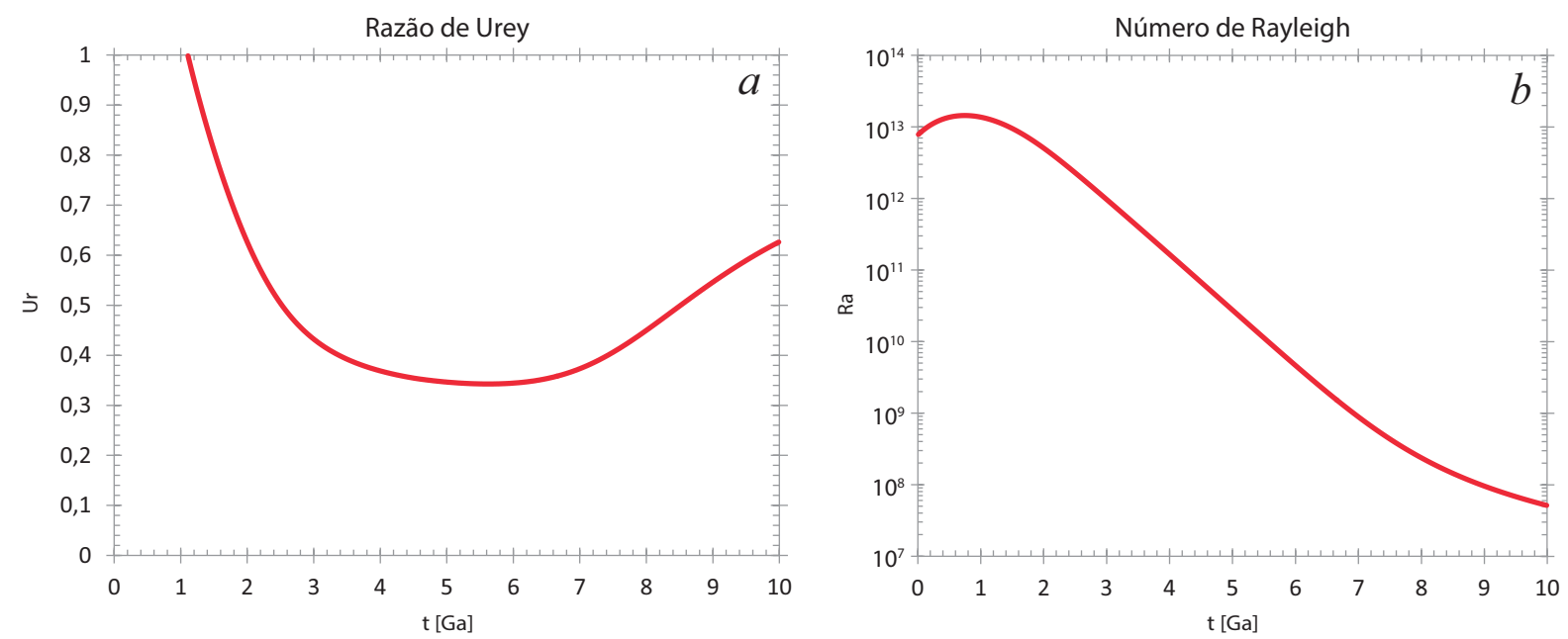

Figura 2.8: Razão de Urey e número de Raileigh dado pelo modelo de evolução térmica do manto terrestre.

O número de Rayleigh é um número adimensional relacionado com fluxos conduzidos 
por empuxo. Um $R a$ menor do que o valor crítico, $R a_{c r i t}$, para aquele fluido resulta em transferência de calor primariamente por condução. Um $R a$ maior do que o $R a_{\text {crit }}$ para aquele fluido resulta em transferência de calor primariamente por conveção. Para o manto terrestre, $R a_{c r i t}$ é da ordem de milhares e $R a$, considerando que há aquecimento interno por $H$, é dado por (Turcotte e Schubert, 2014):

$$
R a_{H}=\frac{\alpha \rho_{m}^{2} g H^{\prime}\left(R_{e}-R_{i}\right)^{5}}{\kappa k \eta}
$$

onde $\rho_{m}$ é a densidade média do manto inteiro (a massa do manto dividida por seu volume), e $H^{\prime}$ é a taxa de geração de energia radioativa por unidade de massa (a equação 2.2 sem o termo da massa do manto). O resultado para nosso modelo (Figura 2.8b) é que $R a$ é muitas ordens de grandeza maior do que $R a_{\text {crit }}$ para toda a história térmica da Terra e a convecção é o método de transporte de calor preferencial. Embora longe do valor crítico, o número de Rayleigh cai com o tempo, indicando uma crescente dificuldade em manter o transporte de calor via convecção. Num futuro hipotético, distante bilhões ou dezenas de bilhões de anos, uma viscosidade muito alta e um número de Rayleigh abaixo do valor crítico levariam ao transporte de calor a ser executado essencialmente por condução.

Os parâmetros geofísicos indicam, de maneira geral, a diminuição da atividade geológica planetária ao longo do tempo.

\subsubsection{Paleoclima}

As Figuras 2.9, 2.10 e 2.11 reúnem nossos resultados para, respectivamente, a temperatura superficial, pressão parcial de $\mathrm{CO}_{2}$ e massas oceânicas para nosso modelo básico (linhas espessas) junto de resultados de outros trabalhos da literatura (linhas tracejadas finas) e estimativas na literatura dessas variáveis para o passado da Terra (pontos, caixas e setas). Tal reunião de dados num mesmo gráfico pode causar alguma impressão de confusão, mas achamos que a direta comparação de resultados de trabalhos da literatura pode mais facilmente indicar as tendências gerais, as semelhanças e diferenças entre os trabalhos, além de indicar se há alguma convergência quanto aos resultados quando analisados com relação ao tempo de publicação.

A temperatura superficial atual estaria num mínimo na maioria dos modelos, sendo bem mais alta no passado da Terra, caindo até chegar na atual, depois aumentando mais 
bruscamente. Quanto à pressão parcial de $\mathrm{CO}_{2}$, a tendência geral é de queda rápida com o tempo para todos o modelos. Isso ainda é bem coerente com o rápido aumento antrópico no teor de $\mathrm{CO}_{2}$ da atmosfera nas últimas décadas, porque nossa interferência no clima é artificial e passageira. Certamente que ela acarretará em consequências graves para nossa espécie e para muitas outras, mas é um só um instante na escala de tempo com que estamos lidando. Ela faz parte de um modelamento fino além do interesse inicial da maioria dos modelos de definir as grandes tendências de comportamento em grandes escalas de tempo. Por fim, os modelos indicam um maior volume de água nos oceanos no passado e uma possível diminuição no futuro. Em todos os casos, a variação de modelo para modelo pode ser bastante significativa, o que indica que ainda é necessário tomar bastante cuidado ao tomar os resultados numéricos dos modelos. Nossos resultados desviam de algumas dessas tendências mesmo considerando a faixa de incerteza.

Usar a equação 2.12 sem o termo $\tau$ fornece uma temperatura efetiva muito baixa, da ordem de $260 \mathrm{~K}$. Isso indica a importância da atmosfera e do efeito estufa em manter a superfície do planeta aquecida. Como a equação 2.12 depende do fluxo solar e sabemos que o Sol tinha uma luminosidade menor no passado, mantendo os outros parâmetros fixos, a temperatura efetiva seria mais baixa. Em nosso modelo, usar os parâmetros atuais, mas o fluxo de 3,5 Ga atrás, no Arqueano, fornece uma temperatura efetiva de $\sim 268 \mathrm{~K}$. Isso é um problema porque, mesmo considerando alguns períodos de grandes glaciações no passado, há evidências geoquímicas (Karhu e Epstein, 1986; Knauth e Lowe, 2003; Robert e Chaussidon, 2006) e resultados de modelos (Schwartzman, 2002; Franck et al., 2000a, 2006) que indicam temperaturas elevadas (> $320 \mathrm{~K}$ ) para a Terra do Arqueano (Figura 2.9). Como alguns trabalhos fornecem a temperatura da água do mar, a temperatura atmosférica média poderia ser ainda mais alta.

Com isso, encontramos o problema do Sol jovem fraco (Sagan e Mullen, 1972): no passado distante, não recebíamos energia do Sol suficiente para termos temperaturas amenas, mas as temperaturas eram amenas ou altas pelas evidências geoquímicas. Ainda não há solução para o paradoxo (Feulner, 2012), mas há sugestões promissoras e interessantes.

Uma solução para esse problema seria que o Arqueano teria uma atmosfera diferente da atual, mais rica em gases estufa (com um $\tau$ maior em nosso modelo). Essa hipótese é confirmada por evidências geoquímicas (Rye et al., 1995; Mora et al., 1996; Kaufman e Xiao, 2003; Ohmoto et al., 2004; Hessler et al., 2004; Cerling et al., 2005; Sheldon, 


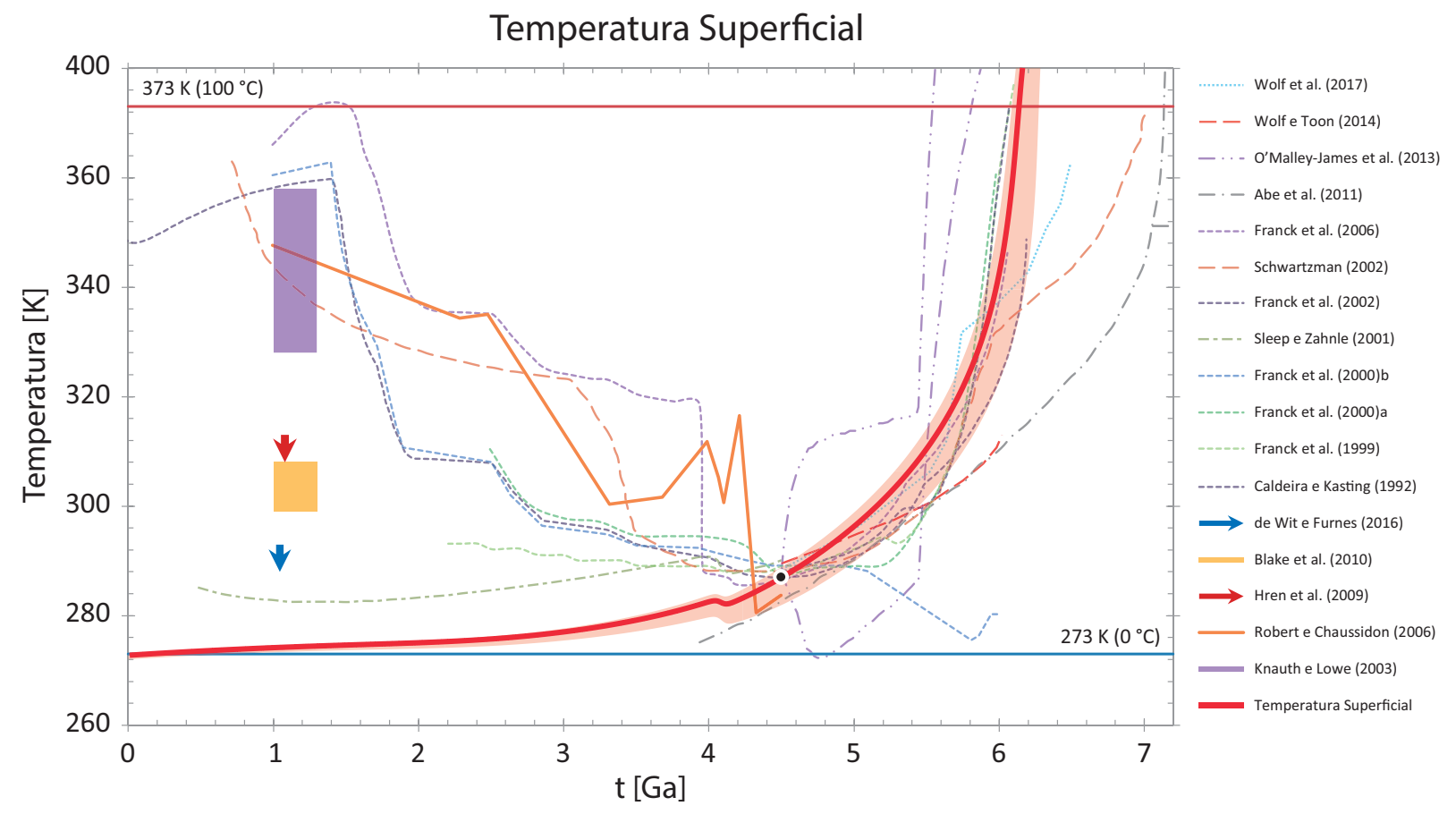

Figura 2.9: Temperatura superficial terrestre ao longo do tempo. Nosso resultado é a linha vermelha cheia espessa com a incerteza dada pela região vermelha semitransparente ao redor. Linhas tracejadas e pontilhadas são resultados de outros modelos da literatura. Outras curvas e figuras indicam estimativas geoquímicas. Caixas indicam incertezas e setas indicam valores máximos. A temperatura superficial média atual é dada pelo ponto preto com contorno branco.

2006; Driese et al., 2011) que indicam uma maior pressão parcial de $\mathrm{CO}_{2}$ na atmosfera nos últimos 3 Ga (Figura 2.10). No entanto, os modelos (em especial Franck et al. $(2002,2006)$ ) indicam que tal teor de $\mathrm{CO}_{2}$ não seria suficiente para manter as temperaturas esperadas, sendo preciso mais.

Temperaturas médias ao redor de $273 \mathrm{~K}$ podem não ser suficientes para encerrar a Terra em uma glaciação constante (Terra bola de neve). Se a temperatura média se mantiver acima de $\sim 260 \mathrm{~K}$, regiões livres de gelo ainda seriam possíveis com gelo restrito a latitudes acima de $\sim 30^{\circ}$ (Tajika, 2003). Se o gelo avançar mais em direção ao equador, uma fração considerável do planeta estaria coberta por material de alto albedo e isso poderia levar a um efeito bola de neve em direção a uma glaciação global.

Nosso modelo consegue manter $T_{s}$ acima de $273 \mathrm{~K}$ por todo o passado de nosso planeta com a $P_{\mathrm{CO}_{2}}$ parcialmente acima dos dados. Manter a temperatura acima de $273 \mathrm{~K}$ pode ser suficiente para manter o planeta habitável segundo nosso critério, mas não é suficiente para atingir as temperaturas esperadas. Como outros modelos, podemos acertar na temperatura, mas errar no $\mathrm{CO}_{2}$, ou acertar no $\mathrm{CO}_{2}$, mas errar na temperatura. 


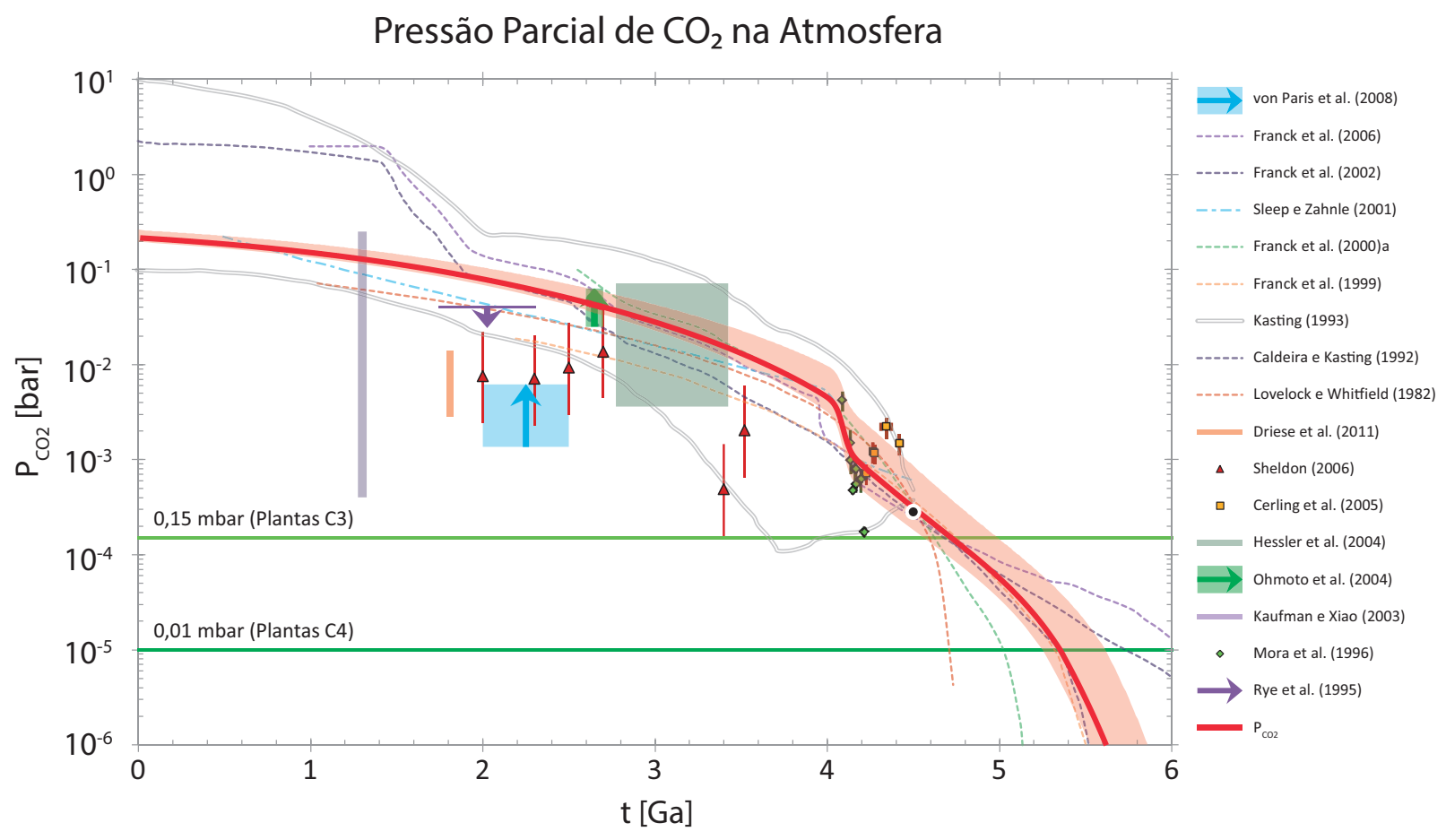

Figura 2.10: Pressão parcial de $\mathrm{CO}_{2}$ na atmosfera terrestre ao longo do tempo. Nosso resultado é a linha vermelha cheia espessa com a incerteza dada pela região vermelha semitransparente ao redor. Linhas tracejadas e pontilhadas são resultados de outros modelos da literatura. As duas linhas duplas indicam valores máximos e mínimos no modelo de Kasting (1993). Outros pontos e figuras indicam estimativas geoquímicas. Caixas indicam incertezas e setas indicam valores máximos ou mínimos. A Pressão parcial média atual de $\mathrm{CO}_{2}$ é dada pelo ponto preto com contorno branco.

Mais recentemente, alguns trabalhos (Sleep e Hessler, 2006; Hren et al., 2009; Blake et al., 2010; de Wit e Furnes, 2016) vêm desafiando a ideia de um Arqueado muito quente em detrimento de um Arqueano de temperaturas mais amenas $(<315 \mathrm{~K})$ e próximas das atuais. Combinando essa informação com outras variáveis que poderiam interferir na temperatura do planeta, como o albedo superficial (Rosing et al., 2010), área de cobertura e propriedades das nuvens (Goldblatt e Zahnle, 2011; Rondanelli e Lindzen, 2012), pressão atmosférica total (Li et al., 2009), e um "coquetel" de outros gases estufa que poderiam estar presentes na atmosfera Arqueana (Pavlov et al., 2000; Haqq-Misra et al., 2008; Wordsworth e Pierrehumbert, 2013; Byrne e Goldblatt, 2014) e podemos ter melhores chances de coincidir modelos e dados (Wolf e Toon, 2014).

Uma maior temperatura superficial no passado devido ao efeito de outros fenômenos que não da ação de $\mathrm{H}_{2} \mathrm{O}$ e $\mathrm{CO}_{2}$ diminuiria $P_{\mathrm{CO}_{2}}$, por causa do aumento do intemperismo, e potencialmente aproximaria seu valor daqueles das evidências geoquímicas. Isso permitiria o uso de um fator $B$ maior do que 2, compatibilizando com os resultados de Schwartzman 
e Volk (1989).

\subsubsection{Metano e o Problema do Sol Jovem Fraco}

Dos diferentes gases estufa que poderiam contribuir com um maior efeito estufa durante o Arqueano o metano, $\mathrm{CH}_{4}$, parece ser um forte candidato ao posto de mais relevante, sendo mais potente do que $\mathrm{H}_{2} \mathrm{O}$ ou $\mathrm{CO}_{2}$. Mas acaba também sendo mais delicado, facilmente reagindo com o oxigênio ou sofrendo fotólise pela radiação ultravioleta solar, precisando ser constantemente reintroduzido na atmosfera para se manter em quantidades relevantes. Hoje, existe em baixa concentração na atmosfera $(\sim 1$ ppmv) com origem basicamente biológica, embora possa ser abiogênico em alguns casos (Etiope e Klusman, 2002).

No Arqueano, as concentrações de oxigênio eram bem mais baixas, o que favoreceria a manutenção do metano na atmosfera mais do que hoje e favoreceria também microorganismos metanogênicos (produtores de metano), procariontes pertencentes ao reino arqueia que produzem metano como resíduo de metabolismo, vivendo em ambientes anóxicos, são sensíveis à presença mesmo de pequenas quantidades de oxigênio, frequentemente encontrados hoje em dia em ambientes seletos como pântanos ou no trato digestivo de ruminantes e humanos. Alguns modelos (Pavlov et al., 2003; Kasting, 2005; Haqq-Misra et al., 2008) indicam que concentrações de metano próximas às de $\mathrm{CO}_{2}$ que existem hoje na atmosfera ( 100-1000 ppmv) poderiam manter a Terra do Arqueano com temperaturas semelhantes às atuais.

Micro-organismos metanogênicos podem prosperar em temperaturas altas, como 40 ou $60{ }^{\circ} \mathrm{C}$ (Zeikus e Winfrey, 1976; Zinder et al., 1984) ou até além dos $120^{\circ} \mathrm{C}$ (Tung et al., 2005; Jabłoński et al., 2015). Isso poderia contribuir para o aquecimento da atmosfera, porque a produção de metano aumentaria o efeito estufa, aquecendo a superfície, o que promoveria o aumento da produção de metano pela população de micro-organismos metanogênicos, o que aumentaria o efeito estufa e assim sucessivamente. Muitos fatores podem limitar isso, claro. Um importante é a produção de material orgânico pela fotólise do metano, produzindo uma neblina orgânica que poderia causar um anti-efeito estufa, resfriando a superfície, análogo ao que deve acontecer em Titã (McKay et al., 1991, 1999). Esse resfriamento diminuiria a produção de metano pelos micro-organismos metanogênicos, o que por sua vez inibiria a produção da neblina e o resfriamento. Funcionaria como um sistema de equilíbrio de temperatura. A pressão parcial de $\mathrm{CH}_{4}$ necessária para a formação 
dessa neblina está relacionada à pressão parcial de $\mathrm{CO}_{2}$, com modelos indicando que para uma razão $\mathrm{CH}_{4} / \mathrm{CO}_{2} \gtrsim 1$ já haveria formação abundante de neblina, e o limiar de formação estaria em $\mathrm{CH}_{4} / \mathrm{CO}_{2} \approx 0,1$ (Haqq-Misra et al., 2008). Como $P_{\mathrm{CO}_{2}}$ foi maior no passado e numa época de atmosfera anóxica, é possível que tenha havido um alto teor de metano na atmosfera antes do ponto de equilíbrio ser atingindo com a neblina. Mas isso não duraria para sempre. Os grandes períodos de oxigenação do planeta em $\sim 2,2$ e $\sim 0,7$ Ga atrás atingiram fortemente os micoorganismos metanogênicos e devem ter diminuído bastante as concentrações de metano na atmosfera, o que pode estar relacionado a alguns dos períodos de grandes glaciações no passado do planeta (Cowen, 2005; Nisbet e Nisbet, 2008; Young, 2013).

Algumas limitações a respeito do real poder estufa do metano (Haqq-Misra et al., 2008) e de sua abundância atmosférica (Olson et al., 2016) podem diminuir sua eficácia como solução para o paradoxo, mas ele ainda se mantém num papel de destaque, devendo ser usado em conjunto com os outros fatores mencionados anteriormente e não sozinho.

\subsubsection{Os Oceanos do Passado}

Diferentemente dos outros modelos, não obtivemos uma rápida e intensa desgaseificação do manto aumentando grandemente o volume dos oceanos no passado do planeta (Figura 2.11). Nossos resultados são uma modesta mudança na massa dos oceanos, com um aumento máximo de $23 \%$ com relação ao volume atual em $t=1,5$ Ga. Esse valor está mais de acordo com algumas evidências e com os resultados de Franck e Bounama (1995), mas é difícil discernir alguma convergência nos modelos com a grande variação de resultados. Como comentado antes, o menor fluxo de calor e a menor taxa de expansão do assoalho oceânico no passado em comparação com os outros modelos também diminuiu as trocas gasosas entre manto e superfície, provavelmente não permitindo um aumento muito grande do volume dos oceanos.

Esse pequeno aumento parece impactar menos na profundidade efetiva dos oceanos (Figura 2.11b) do que o aumento no volume (e na área superficial) da crosta continental (equação 2.7 e Figura 2.2). O que parece acontecer é que conforme a crosta continental se avoluma ela ocupa uma maior área superficial do planeta e as bacias oceânicas se aprofundam, mantendo um volume de água equivalente numa área menor pelo aprofundamento da bacia, não causando muita transgressão ou regressão marinha em nosso modelo. Por 


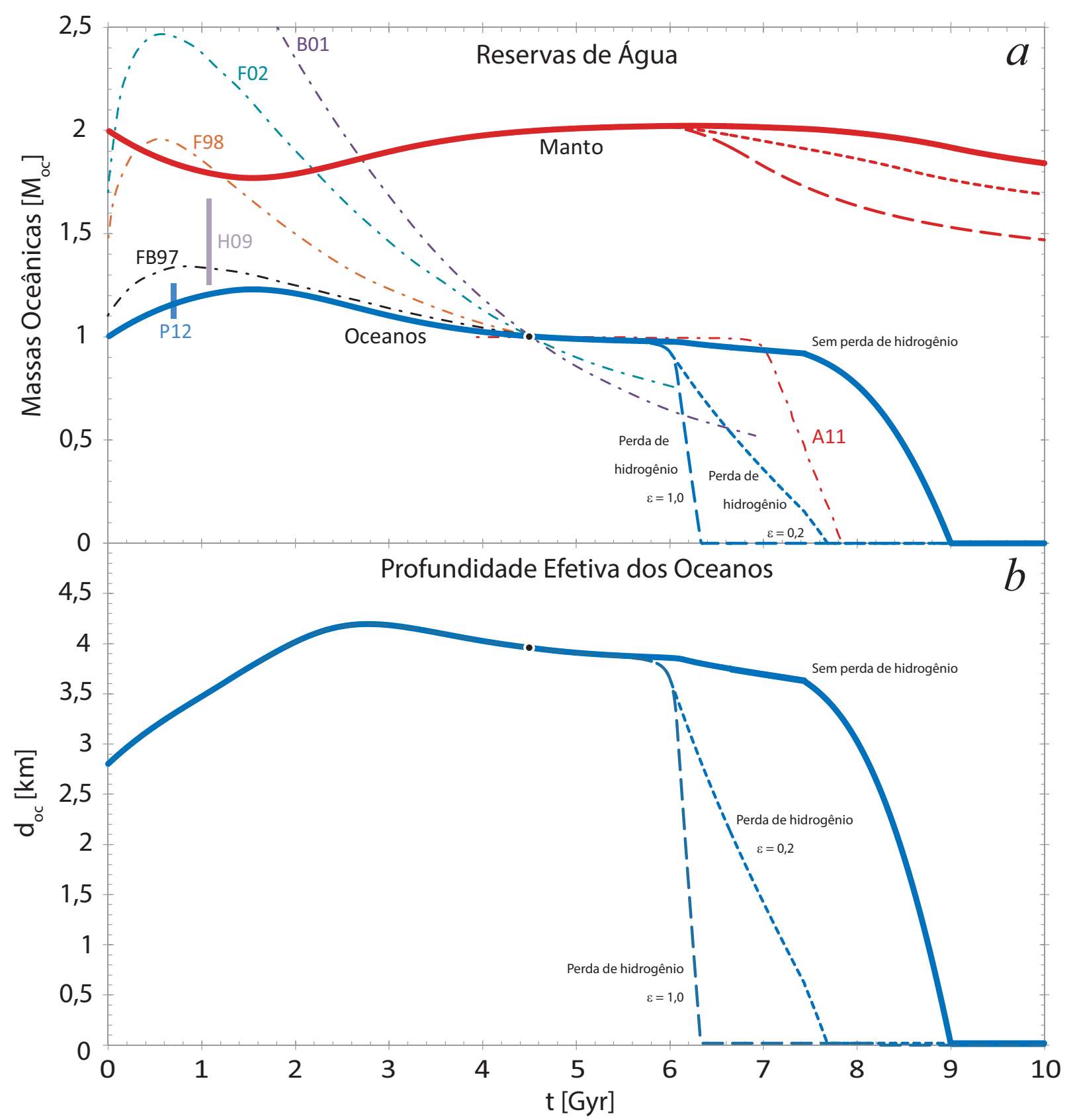

Figura 2.11: a) Quantidade de água nos reservatórios do manto e dos oceanos em nosso modelo dada em massas oceânicas atuais. As duas barras verticais marcam estimativas geoquímicas. Linhas ponto tracejadas indicam resultados de outros modelos da literatura. b) Profundidade efetiva dos oceanos terrestres em nosso modelo. Linhas tracejadas indicam valores considerando perda de água por escape de hidrogênio para dois valores do coeficiente de eficiência. A11 = Abe et al. (2011), B01 = Bounama et al. (2001), F98 = Franck (1998), F02 $=$ Franck et al. (2002), FB97 = Franck e Bounama (1997), H09 = Hren et al. (2009), P12 = Pope et al. (2012).

isso $d_{o c}$ está inicialmente mais relacionada com $A_{c c}^{N}$ do que com $M_{o c}$. A relação com $M_{o c}$ é maior no futuro, quando haverá perda de água líquida da superfície para a atmosfera, por causa do aumento das temperaturas, e perda de água da atmosfera para o espaço. 


\subsubsection{O Futuro da Biosfera}

A perda de água devido à troca de voláteis entre manto e superfície parece que não será um fator relevante para a manutenção da habitabilidade. Ao contrário de outros modelos (Bounama et al., 2001; Franck et al., 2002) não encontramos nenhuma mudança significativa no volume e na profundidade efetiva dos oceanos nos próximos $\sim 1,5$ Ga. A perda de água por fotólise parece ser um perigo maior. Nas Figuras 2.11a e $b$ a linha cheia azul é o caso sem perda de água para o espaço. A água dos oceanos é perdida muito mais lentamente simplesmente por evaporação para a atmosfera conforme as temperaturas se elevam até o ponto crítico de $647 \mathrm{~K}$ e 221 bar. A linha tracejada azul é o caso com perda de água por fotólise segundo as equações 2.18-2.21 usando o coeficiente de eficiência $\varepsilon=0,2$. A perda de água já se inicia em 1,4 Ga e segue bem mais rápido do que no primeiro caso. Isso acontece porque, conforme as temperaturas aumentam, mais água dos oceanos é posta na atmosfera, quando $T_{S}$ atinge $~ 340 \mathrm{~K}$ a fração de água na estratosfera é alta o suficiente a ponto das perdas por fotólise começarem a ser significativas. Conforme a água é quebrada, o hidrogênio é perdido para o espaço e o oxigênio reage com as rochas. Conforme água é perdida da atmosfera, mais água é retirada dos oceanos. A redução de água dos oceanos desestabiliza o equilíbrio de fluxo entre manto e superfície mantido pelos últimos dois bilhões de anos fazendo o manto perder água. O fluxo resultante de água acaba sendo: manto $\rightarrow$ oceanos $\rightarrow$ atmosfera $\rightarrow$ espaço e rochas.

Como um planeta com pouquíssima água pode permanecer com temperaturas no intervalo habitável por mais tempo do que um planeta oceano, a perda de água poderia se dar, se rápida suficiente, antes que as temperaturas atingissem $373 \mathrm{~K}$, permitindo ao planeta ter uma sobrevida habitável posterior à data de $\sim 1,6 \mathrm{Ga}$.

As Figuras 2.11a e $b$ também apresentam o resultado para $\varepsilon=1,0$. Nesse caso, a perda de água é adiantada, mas isso ainda só se daria após as temperaturas atingirem níveis inabitáveis de $450 \mathrm{~K}$. Então, embora seja possível que a Terra perca sua água durante o efeito estufa úmido, impedindo que entremos num efeito estufa desenfreado, nós não conseguimos esse resultado por nosso modelo.

A perda de água poderia interferir na tectônica de placas por prejudicar a lubrificação entre as placas (Mian e Tozer, 1990; van der Lee et al., 2008; Korenaga, 2010). Como não modelamos a fricção entre placas ou suas velocidades não temos como dizer qual efeito isso 
tem ou qual o mínimo de água para manter o regime de tectônica de placas funcionando adequadamente para a habitabilidade do planeta. Como isso se dará tardiamente, após a queda na pressão parcial de $\mathrm{CO}_{2}$ e do aumento de $T_{s}$, não parece ser uma questão muito relevante. Como nosso modelo é mais afinado para temperaturas próximas do intervalo 250-400 K esse resultado deve ser entendido mais como uma tendência e modelos mais adequados devem ser desenvolvidos para tratar disso.

Mesmo com água presente, a diminuição da habitabilidade poderia se desenrolar lentamente por muito tempo, que é o caso com a concentração decrescente de $\mathrm{CO}_{2}$ na atmosfera nos paineis $a$ e $b$ da Figura 2.12. O limite de 0,15 mbar para plantas C3 seria atingido em 170(+320, -110) Ma, seguido pelo limite de 0,01 mbar para plantas C4 em 840(+270, 100) Ma. A pressão parcial de $\mathrm{CO}_{2}$ na atmosfera já chegou a níveis próximos do limite para plantas C3 durante o último milhão de anos, e com uma incerteza de mais de 100 Ma, que é mais de $50 \%$ de seu valor, a compatibilidade com duas das três referências na literatura não facilita uma melhor definição para essa data. O limite para plantas C4 está um pouco melhor definido com uma incerteza proporcionalmente menor, mas ainda há um considerável espalhamento dos dados da literatura. O cenário mais geral é de que a biosfera seria lentamente asfixiada com relação ao carbono facilmente disponível para metabolização e as plantas seriam bastante afetadas, atingindo todo o ecossistema dependente delas, contribuindo para a real asfixiação por diminuírem a concentração de oxigênio na atmosfera. Num processo que se desenrolaria por centenas de milhões de anos, haveria bastante tempo para a seleção natural agir e formas mais eficientes de fotossíntese surgirem. Hoje mesmo, existem micro-organismos fotossintéticos capazes de executar fotossíntese em concentrações de 1 ppm (1/10 do que plantas C4 conseguem) (Birmingham e Colman, 1979; Maberly, 1990). Então ambos os limites não são definitivos, mas são desafios, barreiras limitantes. Marcam tempos cada vez mais hostis para a vida e a diminuição da habitabilidade.

Quanto ao aumento da temperatura superficial (Figura 2.9) nosso modelo segue a tendência dos outros modelos na literatura, mas há considerável dispersão nas curvas, com diferenças de mais de um bilhão de anos para quando $T_{s}=373 \mathrm{~K}$ será atingida. Voltando à Figura 2.5 que compara funções de albedo planetário de vários trabalhos, vemos que, embora a forma das curvas seja semelhante, elas variam bastante de trabalho para trabalho e pequenas mudanças no albedo planetário poderiam influenciar consideravelmente na temperatura superficial do planeta. 
0,15 mbar (Plantas C3)

$a$

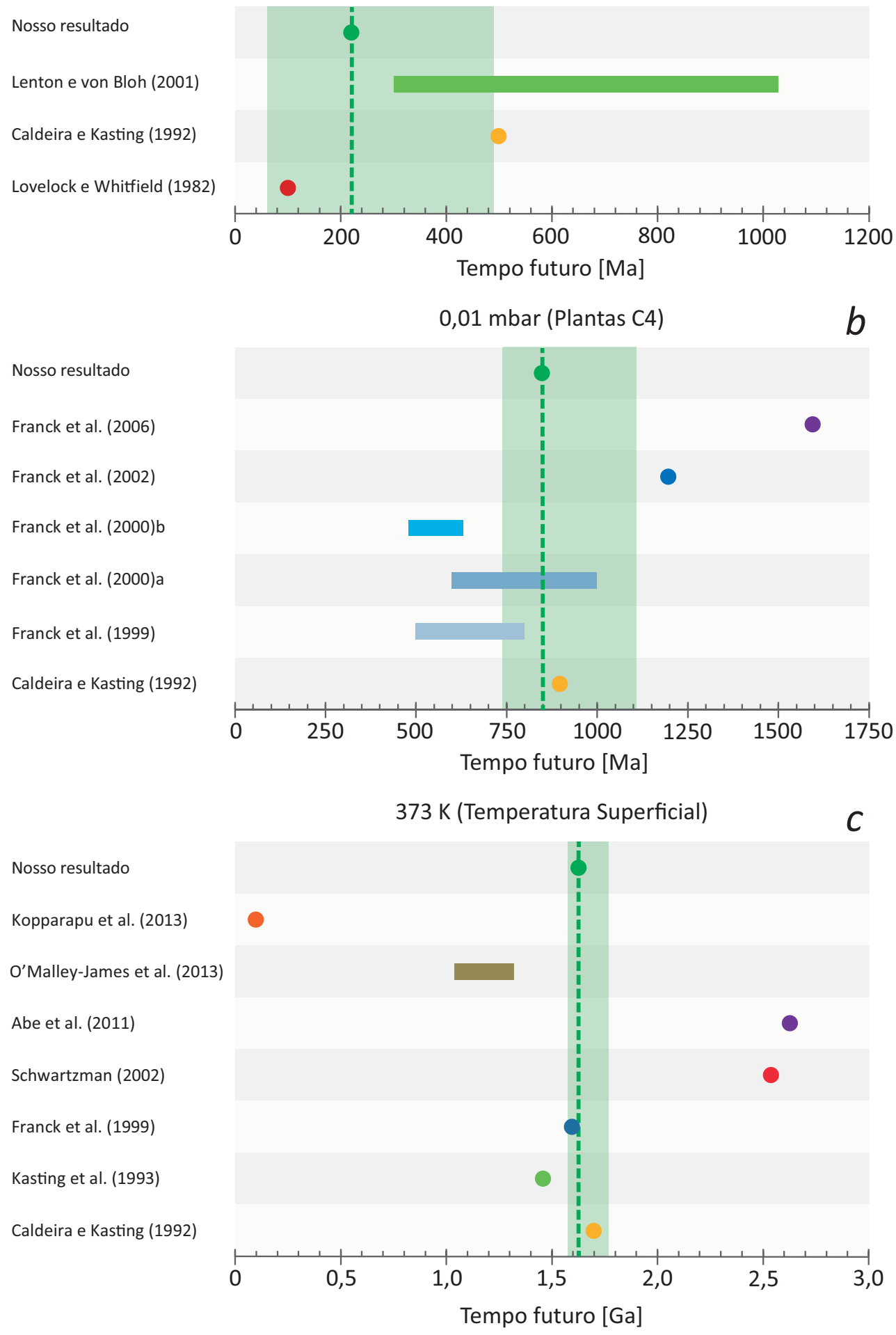

Figura 2.12: Comparação dos resultados de diferentes modelos da literatura quanto ao tempo de vida da biosfera considerando a) limite de $P_{\mathrm{CO}_{2}}$ para plantas $\left.\mathrm{C} 3, b\right)$ limite de $P_{\mathrm{CO}_{2}}$ para plantas $\mathrm{C} 4$, e $c$ ) limite de temperatura muito alta. Nosso resultado são dados pelo ponto verde superior, estendido pela linha tracejada verde para mais fácil comparação. O intervalo de incerteza é dado pela região verde semitransparente. 
Apesar da dispersão, há uma convergência de curvas de temperatura incluindo nossos dados com a faixa de incerteza. Isso pode significar alguma convergência real, com resultados robustos. Porém, uma coisa a ser mantida em mente é que parte disso pode ter origem no grande uso direto ou indireto de resultados dos modelos atmosféricos de Kasting (1988) e de Kasting et al. (1993) por muitos dos trabalhos (o nosso incluído). As curvas mais destoantes, com um aumento das temperaturas mais lento ou mais rápido, são oriundas de modelos mais independentemente elaborados.

Uma limitação de nosso modelo e de modelos zero-dimensionais é a de usar uma única temperatura para caracterizar o sistema. Isso camufla o gradiente de temperaturas que existe em latitude e altitude. Uma $T_{s}=373 \mathrm{~K}$ pode significar um equador muito mais quente do que isso, mas polos e topos de montanhas (sem contar partes da alta atmosfera) ainda em temperaturas habitáveis. O’Malley-James et al. (2013) pondera que tais regiões poderiam servir de refúgio para formas de vida por muitos milhões de anos a mais do que o resto do planeta. Outra possibilidade é a da biosfera profunda (Gold, 1992; McMahon et al., 2013), região subterrânea que mantém temperaturas habitáveis quando isso não é possível na superfície. Esse refúgio interno também não será eterno, porque, quando o efeito estufa desenfreado se iniciar, as temperaturas na superfície poderão chegar a várias centenas de graus Celsius, esterilizando a superfície e até a biosfera profunda pelo fluxo de calor da superfície para a litosfera.

Um caso interessante é o de Kopparapu et al. (2013), por apresentarem um modelo melhorado do modelo apresentado em Kasting et al. (1993), com novos coeficientes de absorção de $\mathrm{H}_{2} \mathrm{O}$ e $\mathrm{CO}_{2}$, então partindo de algo bem próximo do que Kasting et al. (1993) fizeram, mas, mesmo assim, obtendo resultados consideravelmente diferentes. Para eles, a Terra estaria muito mais perto do limite interno da ZHC do que se pensava, o que, com o aumento da luminosidade solar, implicaria em atingir $T_{s}=373 \mathrm{~K}$ muito antes do que os outros modelos indicam. Kopparapu et al. (2013) apresentam um modelo para sondar os limites da ZHC, lidando melhor com os casos extremos que essa sondagem exige. No caso do limite interior da ZHC, consideram uma atmosfera saturada, umidade relativa de 100\%. Esse não é o caso da atmosfera terrestre atual e pode levar a uma superestimação do efeito estufa como indicado por Wolf e Toon (2014). Mesmo assim, é difícil especificar porque as atualizações do modelo de Kasting et al. (1993) para o de Kopparapu et al. (2013) alterariam tanto assim o limite interno da ZHC. 
A Figura 2.12c reúne o tempo necessário estimado por diferentes modelos para atingir $T_{s}=373 \mathrm{~K}$. Kasting et al. (1993) e Kopparapu et al. (2013) usaram o critério de perda de água e de efeito estufa desenfreado para o limite interno da ZHC (e então para o fim da biosfera), por conta disso não podemos comparar nossos resultados diretamente com os deles. O que fizemos foi usar gráficos onde apresentam a variação da temperatura superficial terrestre com relação ao fluxo solar. Procuramos pelo fluxo solar responsável por provocar $T_{s}=373 \mathrm{~K}$ e verificamos quando tal fluxo seria apresentado pela função de luminosidade solar da equação 2.16.

Do mesmo jeito que na Figura 2.9 há uma convergência de alguns pontos estimando o fim da biosfera para daqui a $\sim 1,6 \mathrm{Ga}$, e a incerteza relativa ao valor é a menor, mas há também uma grande dispersão nos dados das referências da literatura. Kopparapu et al. (2013) estima que acontecerá logo, em 100 Ma, o que é até antes do que a maioria das estimativas para o limite de $\mathrm{CO}_{2}$ para plantas C3 na Figura 2.12a, já Schwartzman (2002) e Abe et al. (2011) estimam uma biosfera muito mais longeva, com ainda 2,5 Ga pela frente. Nós estimamos que ocorrerá em 1,63(+0,14, -0,05) Ga. Considerando as limitações dos modelos em relação ao papel das nuvens, as inter-relações do sistema Terra, somente em primeira aproximação modeladas, e resultados recentes de Abe et al. (2011) e de Wolf e Toon (2014), estamos mais inclinados a dizer que o fim da biosfera dificilmente ocorrerá antes de 1,3 Ga, mais provavelmente ao redor 1,6 Ga partindo de hoje, talvez ocorrendo tão tardiamente quanto 1,77 Ga. Alguns trabalhos indicam uma sobre vida para a biosfera além dessas datas e é preciso mais pesquisas sobre isso.

\subsection{Conclusões Parciais}

Construímos um modelo mínimo da co-evolução da geosfera, atmosfera e biosfera de nosso planeta para avaliar sua habitabilidade ao longo de bilhões de anos e estimar o tempo de vida da biosfera. Perda de água por trocas gasosas entre o manto e a superfície parece que será o menos relevante dos fatores limitantes para a biosfera. A diminuição da concentração de $\mathrm{CO}_{2}$ na atmosfera imporá um impacto grande na biosfera ao continuamente privar cada vez mais as formas de vida fotossintetizantes de carbono. Mas só com as temperaturas atingindo $373 \mathrm{~K}$ que o planeta se tornará basicamente inabitável ao redor de 1,6 Ga no futuro, antes do choque da Via Láctea com a Grande Nuvem de Magalhães 
em 2,4 Ga (Cautun et al., 2018), antes do choque com a Galáxia de Andrômeda em 4,5 Ga (van der Marel et al., 2019), e bem antes do Sol se tornar uma gigante vermelha em 7,6 Ga, calcinando e depois engolindo o planeta (Schröder e Connon Smith, 2008) 
Capítulo 3

\section{Habitabilidade Planetária}

Neste capítulo vamos utizamos o modelo construído no capítulo anterior para averiguar seu comportamento com diferentes parâmetros com o intuito de simular planetas telúricos diferentes da Terra e de derivar a ZHC para diferentes massas planetárias e estelares. Para isso, algumas modificações no modelo básico são necessárias.

\subsection{Modificações no Modelo}

A primeira modificação é o albedo planetário. Estrelas com temperaturas efetivas diferentes depositam quantidades diferentes de energia em partes diferentes do espectro eletromagnético (têm espectros diferentes). Isso influencia na quantidade de energia que de fato é absorvida ou refletida pelo planeta, então alterando o albedo planetário. A parametrização de Williams e Kasting (1997) que usamos não depende da massa estelar (e então da temperatura efetiva), então tivemos de ir por outro caminho. O que fizemos foi criar uma grande tabela de dados alterando os parâmetros da parametrização de Williams e Kasting (1997) e juntando com os resultados de Kasting et al. (1993) para o albedo planetário de um planeta como a Terra para três diferentes estrelas: F0 $\left(\sim 1,3 \mathrm{M}_{\odot}\right)$, Sol $\left(1,0 \mathrm{M}_{\odot}\right)$ e $\mathrm{M} 0\left(\sim 0,5 \mathrm{M}_{\odot}\right)$ (Figura 3.1). Esse é um fator limitante no intervalo de massas estelares que podemos analisar.

Posuindo os resultados de $A_{p}$ em função de $T_{s}, P_{\mathrm{CO}_{2}}, a_{s}$ e da massa estelar, $M_{*}$ (fixamos $Z$ em $60^{\circ}$ como descrito na seção 2.2.1 do capítulo anterior), ajustamos uma série de funções para esses dados. A parametrização final está no apêndice A.2 e a comparação com as outras curvas de albedo planetário está na Figura 3.2.

Nossa nova função de albedo planetário difere da anterior, mas é uma diferença pequena 


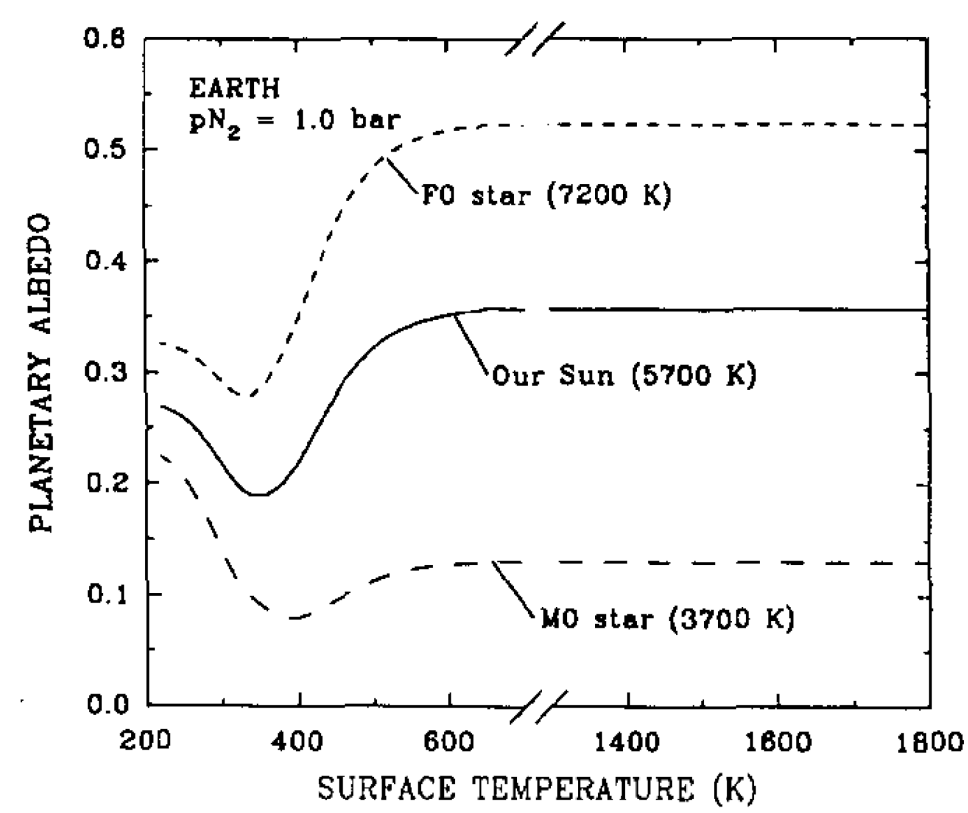

Figura 3.1: Albedo planetário em função da temperatura para três diferentes estrelas: F0 $\left(\sim 1,3 \mathrm{M}_{\odot}\right)$, Sol $\left(1,0 \mathrm{M}_{\odot}\right)$ e M0 ( 0,5 $\left.\mathrm{M}_{\odot}\right)$ segundo Kasting et al. (1993).

quando comparada com a grande variação entre as funções de albedos na literatura. Um albedo mais alto diminui a quantidade de energia absorvida e a temperatura superficial. Lembrando como a temperatura superficial para nosso modelo básico da Terra no último capítulo foi baixa no passado com a menor luminosidade estelar inicial, então a Terra poderia estar marginalmente fora da ZHC no passado distante usando essa nova função de albedo. A flexibilidade de poder usar o albedo mais corretamente para outras estrelas além do Sol cobre esse erro associado.

Uma segunda modificação no modelo foi introduzir um escalonamento para alguns parâmetros ao variar a massa planetária. Variar a massa planetária linearmente não necessariamente alteraria outros parâmetros de maneira linear, como o raio planetário. A Figura 3.3 compara algumas relações massa-raio para planetas rochosos na literatura.

A composição do planeta parece influenciar consideravelmente na relação massa-raio com planetas mais ricos em metais (curva de baixo, vermelha) sendo os mais compactos, planetas ricos em gelo (curvas de cima, azuis) os mais volumosos, e os mais rochosos (curvas marrons) seriam intermediários. A Terra tem uma composição algo 1/3 metálica e 2/3 rochosa, composição indicada pela curva verde no modelo de Fortney et al. (2007). As curvas parecem coincidir e convergir muito bem entre os diferentes trabalhos. Inclusive, o ajuste empírico de Weiss et al. (2018) coincide muito bem com a curva de composição 


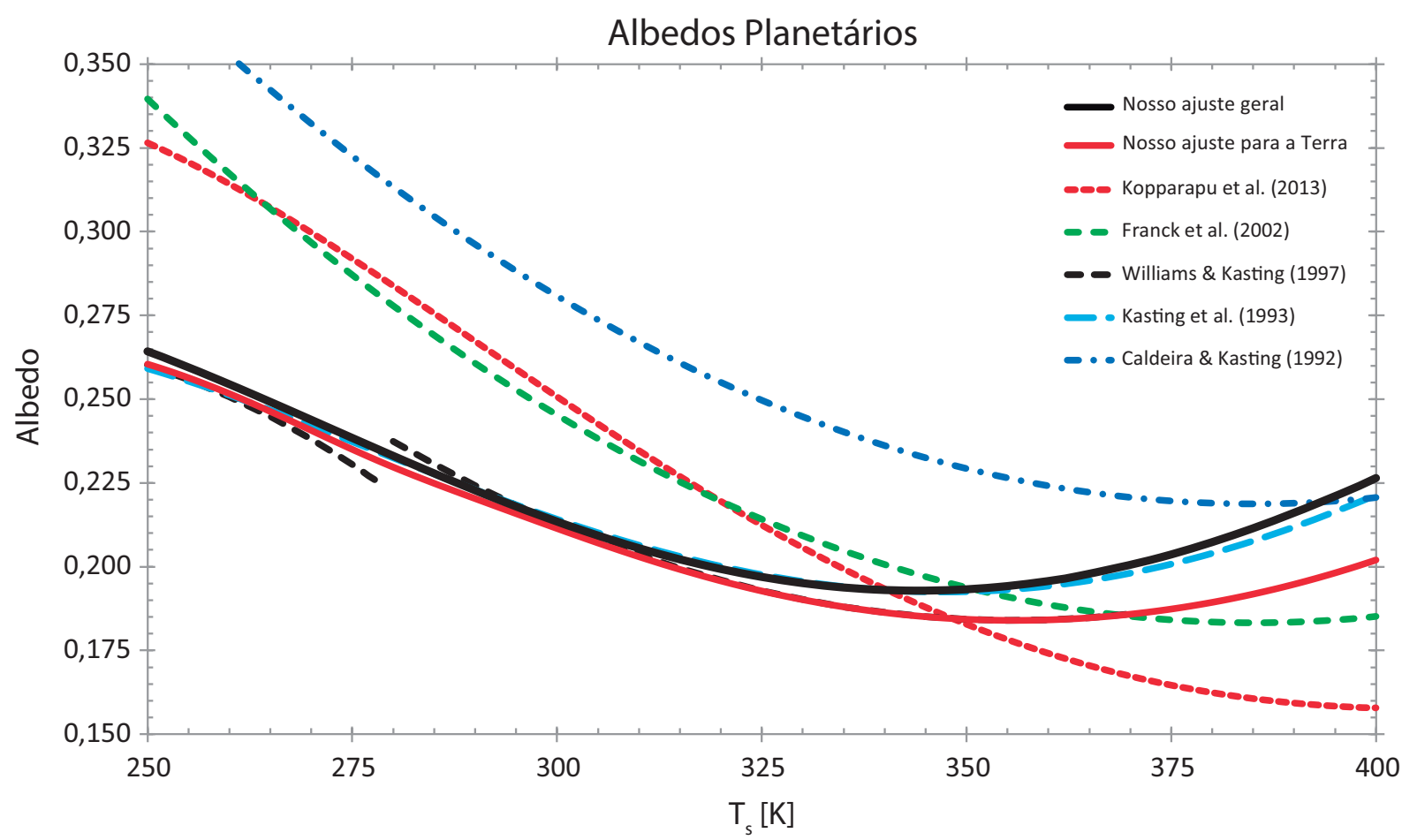

Figura 3.2: Comparação do albedo planetário dado por diferentes trabalhos na literatura. A função de Williams e Kasting (1997) é dada com os valores $a_{s}=0,2, Z=60^{\circ}$ e $P_{\mathrm{CO}_{2}}=0,0$. Aqui apresentamos uma nova versão (linha cheia preta) da função de albedo planetário que usamos anteriormente (linha cheia vermelha), dada com os parâmetros $a_{s}=0,2$ e $P_{\mathrm{CO}_{2}}=0,0$.

terrestre e tem o acréscimo importante de mostrar que o raio aumenta fortemente a partir de $\sim 4 \mathrm{M}_{\oplus}$. Isso é provavelmente pelo acúmulo de material mais leve como gelo ou pelo avolumamento das atmosferas, eles estariam se transformando em mininetunos. Foi por esse motivo que decidimos limitar nosso estudo a $4 \mathrm{M}_{\oplus}$ em vez do limite algo mais comum de $\sim 10 \mathrm{M}_{\oplus}$, pois seria mais difícil encontrar uma superterra em vez de um mininetuno acima de $\sim 4 \mathrm{M}_{\oplus}$.

Quando alterarmos a massa planetária em nosso modelo, faremos usando a relação massa-raio de Fortney et al. (2007) com uma composição 1/3 ferro e $2 / 3$ rocha. Não sabemos se essa composição exata é a mais comum. Se olharmos para o Sistema Solar, os planetas interiores não desviam muito dela, com Vênus e Terra de composição bem próxima, Marte um pouco mais rochoso, e Mercúrio um pouco mais metálico. As grandes luas de Júpiter e Saturno já têm uma fração bem menor de ferro e bem maior de voláteis. Os planetas em que temos interesse, planetas capazes de manter tectônica de placas, com bastante água, mas ainda assim perfazendo apenas $\sim 0,05 \%$ da massa total do planeta, talvez não desviassem muito de $1 / 3$ ferro e $2 / 3$ rocha, mas é difícil dizer qual combinação 


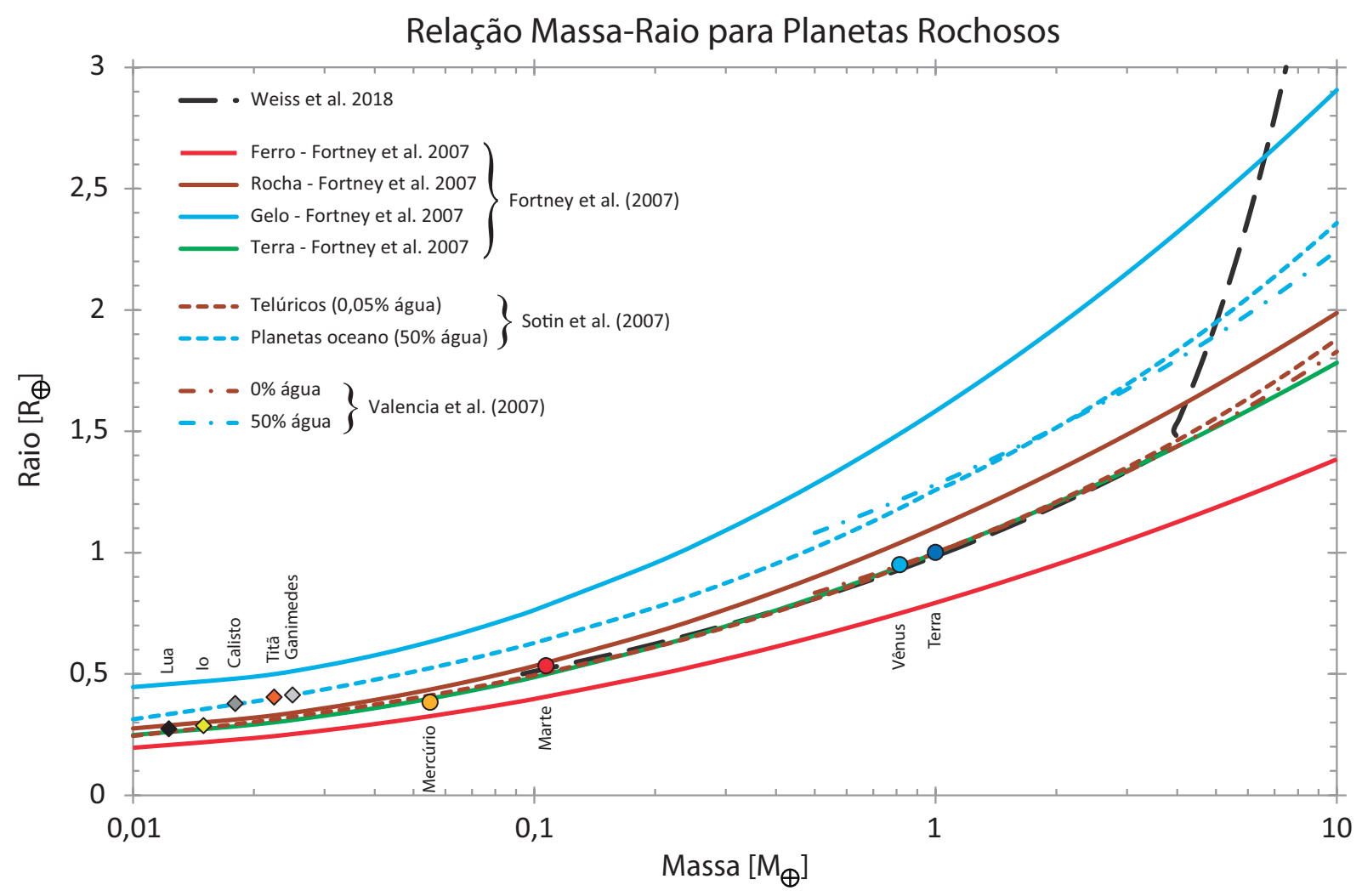

Figura 3.3: Relação massa-raio para planetas rochosos de diferentes composições. Linhas azuis indicam composição principal de gelo, linhas marrons indicam composição principal por rochas, e linha vermelha indica composição principal de ferro. Linha verde indica composição da Terra de 1/3 metal e 2/3 rocha. Linha preta tracejada empírica de Weiss et al. (2018) indica rápido aumento do raio para massas acima de $\sim 4 \mathrm{M}_{\oplus}$, indicando maior papel de materiais menos densos na constituição do planeta e provável começo de mininetunos. O termo "telúrico" usado por Sotin et al. (2007) tem sentido um pouco diferente do usado em nosso trabalho, estaria mais próximo do que chamamos por "rochoso".

seria a melhor ou mesmo qual seria a mais frequente.

A Terra é o único planeta conhecido com tectônica de placas. Na literatura, há trabalhos que argumentam que superterras teriam maior facilidade de apresentar tectônica de placas do que planetas de massa terrestre (Valencia et al., 2007; Van Heck e Tackley, 2011; Tikoo e Elkins-Tanton, 2017), outros que seria mais difícil (O’Neill et al., 2007; Kite et al., 2009), e há até os que argumentam que dependeria de condições iniciais, não apenas da massa do planeta (Lenardic e Crowley, 2012). De toda forma, na incerteza, seguiremos com nosso modelo com tectônica de placas.

Uma última modificação é que não vamos usar nosso modelo de biosfera nas simulações seguintes. Mesmo admitindo claramente a influência que a vida pode ter nas condições de habitabilidade de um planeta e nas mudanças causadas pela vida na Terra, estamos mais interessados nas condições abióticas de habitabilidade, até por exigir suposições mais 
fracas e simples do que a prévia existência de vida no planeta. O aparecimento de plantas vasculares e micro-organismos especializados pode também ser apenas um evento terrestre, ou o momento em que isso ocorreu em nosso planeta pode ser muito tardio ou muito primevo, não há como dizer muito bem no momento. Então preferimos não estudar isso neste trabalho.

Os raios interno (raio do núcleo) e externo do manto variamos proporcionalmente com o raio planetário obtido da relação massa-raio e a massa do manto variamos linearmente com a massa planetária. Quando não alterada diretamente, a quantidade de água nos oceanos e no manto foi variada proporcionalmente com a massa planetária, então um planeta com o dobro da massa da Terra teria o dobro da massa de água. Novamente, não sabemos o quão eficiente é o acúmulo ou aporte de água para os planetas rochosos em função de sua massa, distância à estrela ou outros fatores, mantivemos o valor terrestre. Por fim, a espessura máxima dos continentes antes de sofrerem delaminação (cederem e fluírem sob o próprio peso) e a profundidade máxima dos oceanos antes de cobrirem toda a terra variariam com a massa do planeta, porque um planeta mais massivo teria montanhas mais baixas e bacias mais rasas por conta da maior aceleração da gravidade, o oposto ocorreria num planeta menos massivo. Utilizamos a parametrização de Cowan e Abbot (2014) para a profundidade máxima dos oceanos para manter a habitabilidade:

$$
\begin{aligned}
d_{o c}^{\text {max }} & =\frac{d_{g}^{\text {max }}\left(\rho_{m}-\rho_{\text {gra }}\right)-d_{\text {bas }}\left(\rho_{m}-\rho_{\text {bas }}\right)}{\rho_{m}-\rho_{a}} \\
d_{\text {gra }}^{\text {max }} & =70 \mathrm{~km}\left(\frac{g}{g_{\oplus}}\right)^{-1}
\end{aligned}
$$

onde $\rho_{g r a}$ é a densidade média da crosta continental e $d_{g r a}^{\text {max }}$ é a espessura máxima da crosta continental. Os $70 \mathrm{~km}$ foram uma aproximação escolhida por Cowan e Abbot (2014) por serem a espessura da crosta continental no platô dos Himalaias e ela talvez esteja ao redor do limite de espessura para a Terra.

No caso terrestre vimos não haver muitos motivos para supor um enfraquecimento relevante do campo magnético terrestre nos próximos bilhões de anos, então só estudamos a perda de hidrogênio por conta do aumento de temperatura e pela radiação EUV. Agora que vamos variar a massa planetária isso poderia mudar. Um planeta menos massivo, como Marte, tem uma razão área por volume menor do que a Terra e esfriaria mais rápido, 
podendo perder o núcleo metálico externo líquido e o forte campo magnético. Um planeta menos massivo também teria menor capacidade de manter sua atmosfera e moléculas mais pesadas do que hidrogênio e hélio poderiam mais facilmente escapar. Então um planeta menos massivo do que a Terra talvez tivesse maiores problemas em manter sua atmosfera por bilhões de anos e em manter sua habitabilidade. Alguns trabalhos (Dehant et al., 2007; Zuluaga e Cuartas, 2012; Zuluaga et al., 2013b; Driscoll e Bercovici, 2013) se debruçaram sobre a perda de atmosfera por vento estelar e a proteção do campo magnético planetário, no entanto, não pudemos, no tempo disponível, construir um módulo de perda de atmosfera mais geral, então isso ficará faltando. Mas avisamos que a ZHC para planetas de massa sub-terrestre pode ser mais estreita do que será derivada adiante.

Existe a possibilidade de que muitos outros parâmetros de nosso modelo sejam diferentes para massas planetárias diferentes ou outras mudanças, mas, em nossa ignorância e limitações do modelo, vamos manter os outros parâmetros fixos como no modelo básico.

\subsection{Variação da Massa Planetária}

A primeira variação é quanto a massa planetária. Escolhemos a massa terrestre, os extremos do intervalo considerado $\left(0,1-4,0 \mathrm{M}_{\oplus}\right)$ e valores intermediários $\left(0,5\right.$ e $\left.2,0 \mathrm{M}_{\oplus}\right)$. A Figura 3.4 exibe os principais resultados quanto à habitabilidade. O painel $a$ claramente indica uma grande diferença na evolução da pressão parcial de $\mathrm{CO}_{2}$ na atmosfera. $\mathrm{O}$ valor inicial é praticamente o mesmo, mas a queda é muito mais acentuada e rápida para massas menores. O ganho para massas maiores não é muito grande, mas a diferença em tempo para atingir o limite para plantas $\mathrm{C} 4$ é de $\sim 0,9$ Ga entre 0,1 e 4,0 $\mathrm{M}_{\oplus}$, planetas de baixa massas ficariam menos habitáveis mais rápido. Parece que não haveria muito a ganhar se esforçando em buscar especificamente por planetas de massas maiores do que a Terra, mas haveria em se evitar massas abaixo de $\sim 0,5 \mathrm{M}_{\oplus}$.

O painel $b$ da Figura 3.4 apresenta resultados semelhantes, com as massas mais baixas tendo temperaturas mais baixas também, mas o efeito é menos relevante. Como no painel $a$, o planeta de massas $0,1 \mathrm{M}_{\oplus}$ seria o mais prejudicado, ficando abaixo de $273 \mathrm{~K}$ pelos primeiros $\sim 3,5 \mathrm{Ga}$ de simulação. Note como após $t=5,0 \mathrm{Ga}$ as curvas convergem. Nesse ponto a atmosfera estaria tomada de vapor d'água e esta definiria a evolução futura do clima do planeta. 
Retornando às Figuras 2.10, de $P_{\mathrm{CO}_{2}}$, e 2.9, de $T_{s}$, vemos que as temperaturas das massas mais altas da Figura $3.4 b$ estariam quase todas contidas na região de incerteza, o mesmo ocorrendo para a pressão parcial de $\mathrm{CO}_{2}$. As massas menores, e especialmente a massa de $0,1 \mathrm{M}_{\oplus}$ estaria bem fora da região de incerteza. Nas simulações, então, a diferença de comportamento seria maior entre os planetas menos massivos e a massa terrestre do que entre os planetas mais massivos e a massa terrestre.
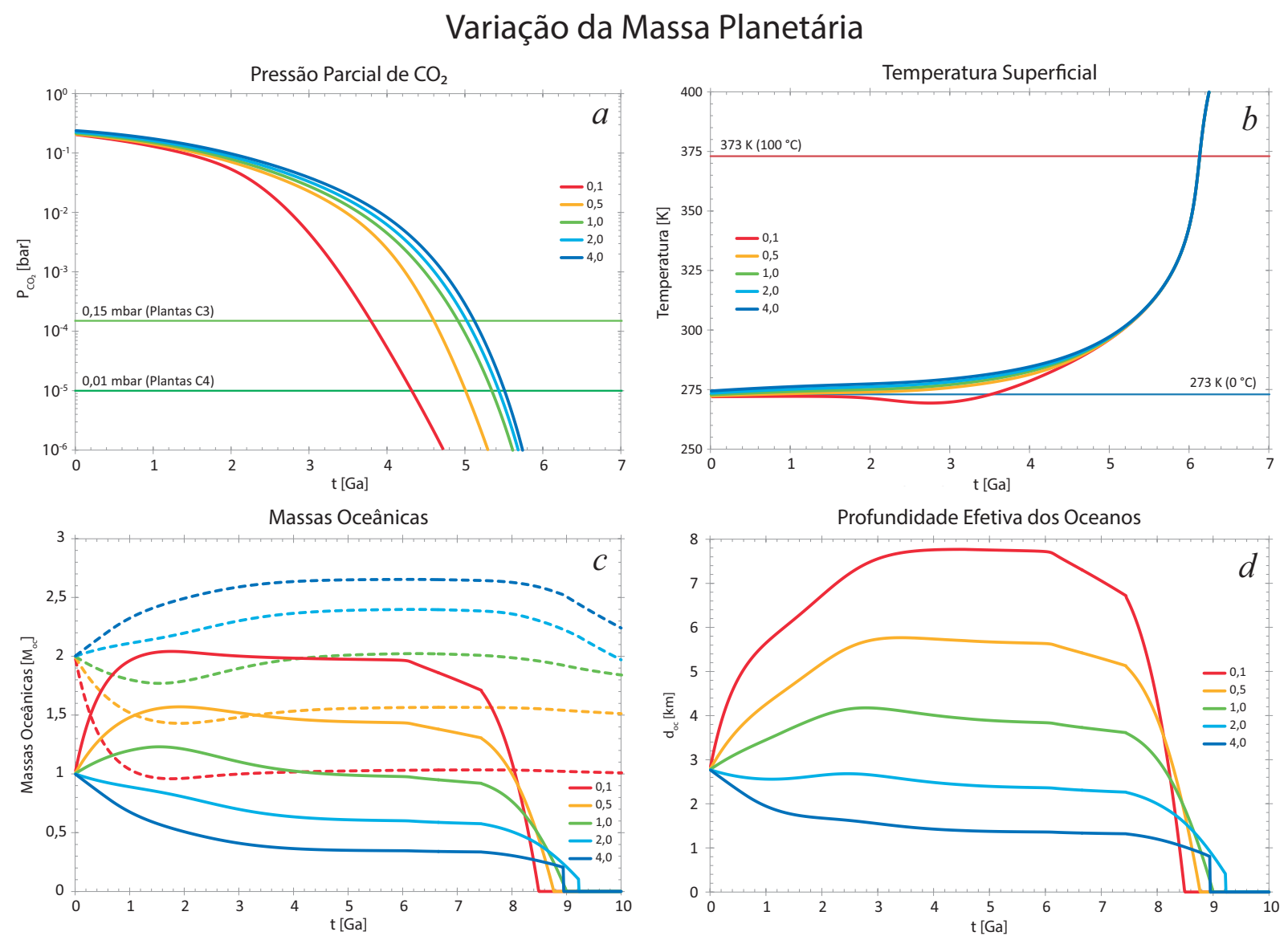

Figura 3.4: Resultados principais do modelo para a variação da massa planetária mantendo os outros parâmetros fixos. Valores da legenda indicam a massa planetária em massas terrestres. No painel $c$ as linhas cheias indicam o valor para os oceanos e as linhas tracejadas para o manto.

Uma das motivações na construção de nosso modelo foi de estudar como a atmosfera se alteraria quando atrelada à geofísica e à evolução térmica do planeta. Nem toda atmosfera, como 10 bar de $\mathrm{CO}_{2}$, poderia ser possível em qualquer tipo de planeta com qualquer idade. O que vemos aqui é que planetas mais massivos do que a Terra poderiam concentrar mais $\mathrm{CO}_{2}$ em suas atmosferas, mas esse efeito parece sutil e, de qualquer forma, mesmo à 273 $\mathrm{K}$, nenhuma $P_{\mathrm{CO}_{2}}$ simulação chegou nem a 1 bar de $\mathrm{CO}_{2}$, o que é menos do que os limites 
explorados, por exemplo, em Kasting et al. (1993). Isso limitaria o alcance da ZHC e faria retroceder o limite externo da ZHC tradicional baseada em água e dióxido de carbono. Um coquetel de gases estufa diferente poderia propiciar o efeito necessário de manter o limite externo da ZHC mais distante da estrela, mas isso não é estudado neste trabalho.

Os painéis $c$ e $d$ da Figura 3.4 apresentam a evolução das reservas de água. A relação aqui parece ser contrária, com a maior massa tendo os valores mais baixos. Isso é porque, com gravidade mais intensa as diferenças de altitude diminuem e as bacias se tornam mais rasas. Também a área do planeta aumenta com o quadrado do raio, então há bem mais área para espalhar a água na superfície.

A maior profundidade oceânica efetiva em baixas massas não é um problema, pois os continentes podem ficar mais espessos do que na Terra, e mesmo na Terra a profundidade de $8 \mathrm{~km}\left(0,1 \mathrm{M}_{\oplus}\right)$ não cobriria todos os continentes. O comportamento curioso é o de trocas entre a superfície e o manto. As massas maiores tenderiam a perder água para o manto, enquanto as massas menores tenderiam a ganhar água do manto. Fixamos o parâmetro $f_{r}$, a fração da água na crosta oceânica que realmente adentra o manto, e esse poderia influenciar no equilíbrio.

Não modelamos a perda de atmosfera por vento solar ou outras causas, mas esta poderia ser significativa nas massas menores. O planeta de $0,1 \mathrm{M}_{\oplus}$ poderia não só ter uma queda na pressão parcial de $\mathrm{CO}_{2}$ mais intensa e rápida do que já tem como também poderia perder água mais rapidamente, trilhando um caminho mais parecido com o de Marte.

A Figura 3.5 reúne os resultados a respeito do manto. Aqui a diferença entre as massas, altas e baixas, é bem mais visível e mais bem espaçada. Veja como todas as massas têm um período de aquecimento inicial (painel c) e esse período é maior quanto maior a massa, a menos do menos massivo, que só esfria, e tende ao equilíbrio termodinâmico mais rapidamente. A viscosidade é bem menor para os mais massivos, permitindo mais fácil convecção e fluxo de calor, do que para os menos massivos. O Número de Rayleigh para o planeta menos massivo é o que atinge valores mais baixos. Esses ainda são de duas a três ordens de grandeza acima do valor crítico, o que, provavelmente, faria com que continuassem convectivos, mas é um indicativo de sua menor capacidade de convecção. 


\section{Variação da Massa Planetária}
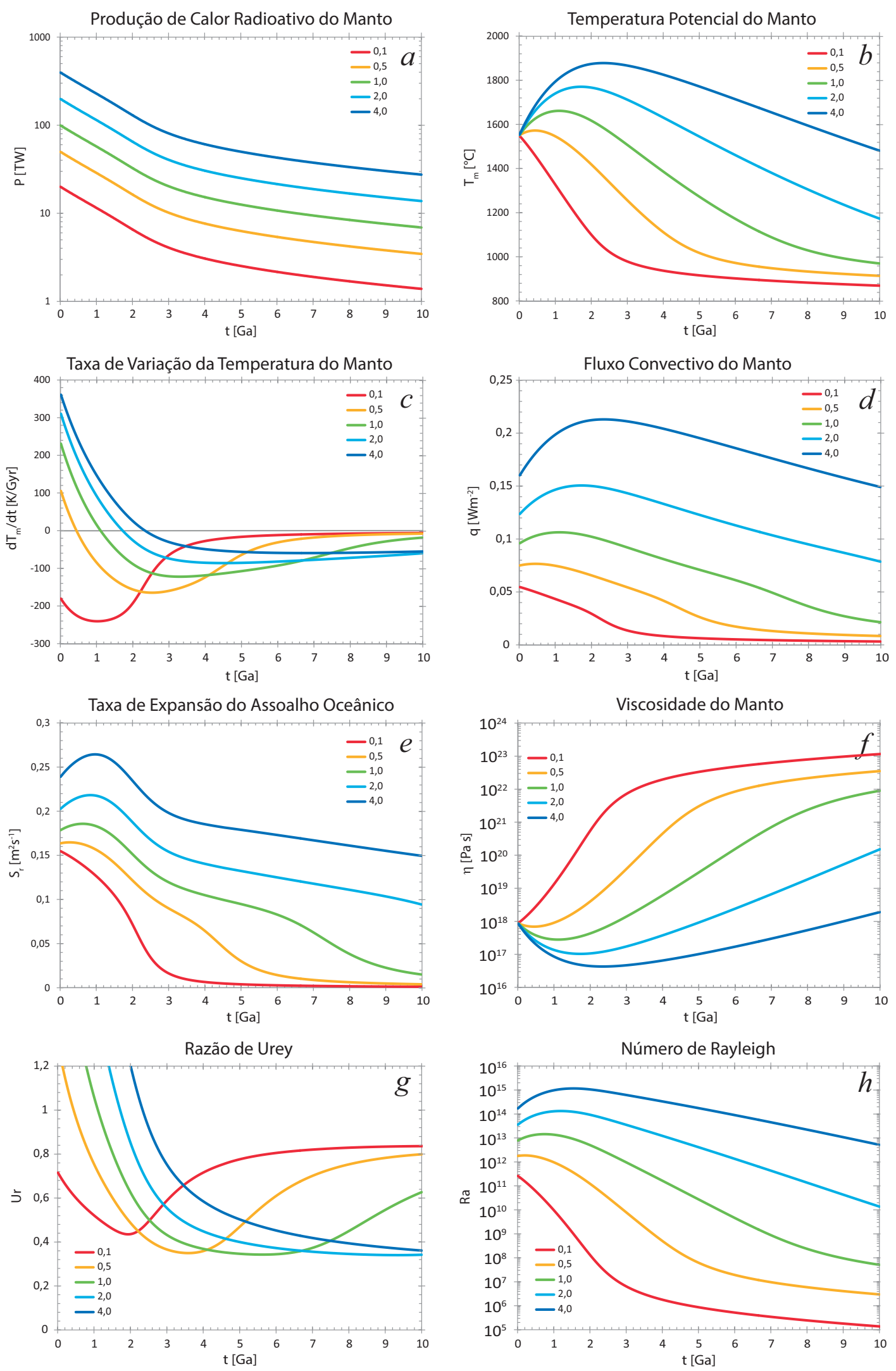

Figura 3.5: Resultados do modelo para a variação da massa planetária mantendo os outros parâmetros fixos. Valores da legenda indicam a massa planetária em massas terrestres. 
Os planetas mais massivos claramente têm mais "vigor" do que os menos massivos e conseguem manter seus parâmetros altos por mais tempo. No entanto, comparando com a Figura 3.4, isso não se traduz em uma habitabilidade excepcionalmente mais alta para eles, havendo só uma moderada a pequena diferença para massas maiores do que $\sim 0,5 \mathrm{M}_{\oplus}$.

\subsection{Variação da Quantidade de Água no Manto}

Variar a quantidade de água no manto tem o trivial efeito de somente alterar a quantidade de água no manto e nos oceanos através dos fluxos entre os dois reservatórios. Esse é um resultado esperado, pois não atrelamos o teor de água no manto a outras variáveis.

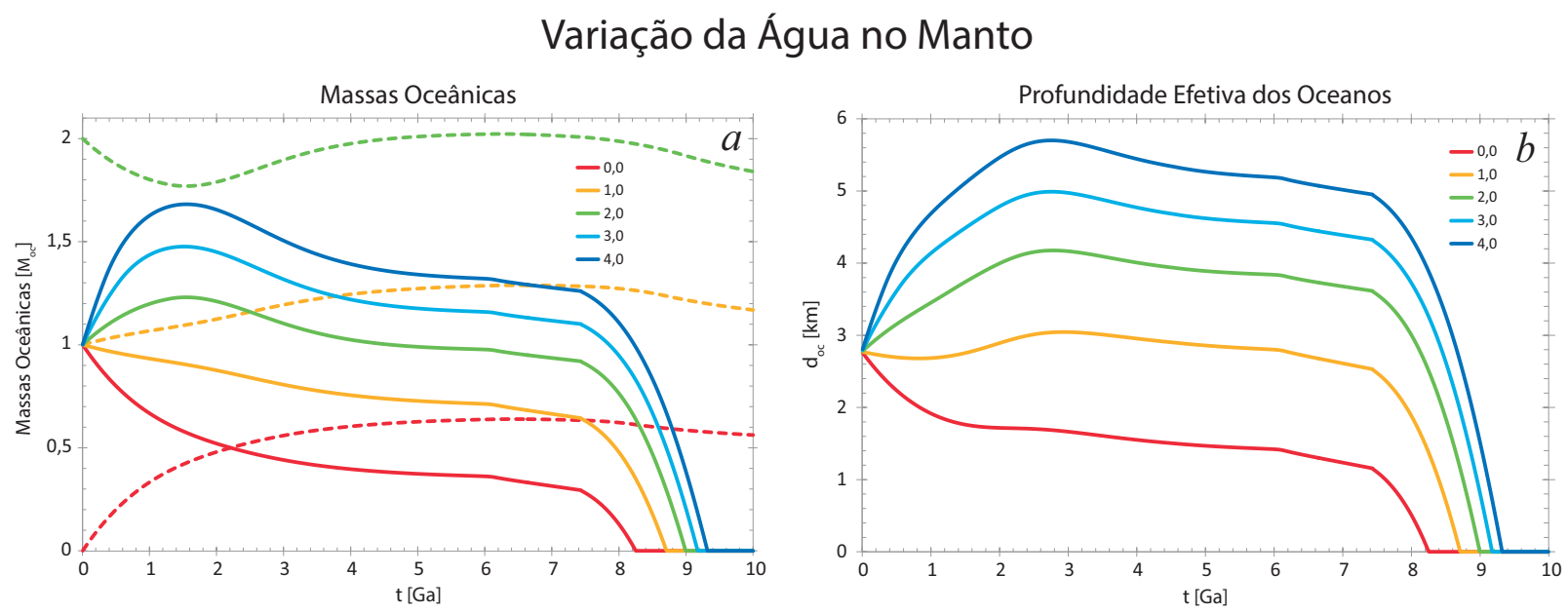

Figura 3.6: Resultados do modelo para a variação da quantidade inicial de água no manto mantendo os outros parâmetros fixos, então para um planeta de 1,0 $\mathrm{M}_{\oplus}$. Valores da legenda indicam valor multiplicativo do valor básico de $2,0 \mathrm{M}_{\mathrm{oc}}$, então 0,1 indica $10 \%, 0,2 \mathrm{M}_{\mathrm{oc}}$. No painel $a$ as linhas cheias indicam o valor para os oceanos e as linhas tracejadas para o manto

Poderíamos ter usado a fração por massa de água no manto de maneira a influenciar na viscosidade, como McGovern e Schubert (1989) e Franck e Bounama (1995) fizeram, onde a viscosidade do manto cairia conforme a fração de água aumentasse. Isso não foi possível por usarmos uma equação para o fluxo de calor bem diferente daquela usado nesses dois trabalhos, com nossa referência (Korenaga, 2006) usando uma viscosidade dependente somente da temperatura do manto.

Para a habitabilidade, o resultado importante é que mesmo dobrando a quantidade inicial de água no manto a desgaseificação seguinte não aumentaria a profundidade efetiva dos oceanos mais do que $\sim 2 \mathrm{~km}$, ainda permitindo muita área seca. Não importando a quantidade inicial de água no manto, pelo menos o último bilhão de anos e os próximos 
dois sofreriam pouca variação no volume de água nos reservatórios, estando em equilíbrio.

Alterar a quantidade de água no manto e alterar o fator $f_{r}$ de maneira a manter $1,0 \mathrm{M}_{\mathrm{oc}}$ hoje poderia ajudar a delimitar o volume do reservatório do manto se usado em conjunto com as estimativas geoquímicas do volume dos oceanos do Arqueano, porque haveria um grande espaço de parâmetros da massa de água inicial no manto e de $f_{r}$ que forneceriam o volume atual de água nos oceanos.

\subsection{Variação da Quantidade de Material Radioativo}

Os painéis $a$ e $b$ da Figura 3.7 são bem semelhantes aos mesmos painéis da Figura 3.4, de variação da massa planetária. Aparentemente, ter mais material radioativo é análogo (tem o mesmo efeito) que ser um planeta mais massivo: aumenta a habitabilidade do planeta ao permitir maior $P_{\mathrm{CO}_{2}}$ e maior $T_{s}$ mais distante da estrela. É curioso que a quantidade de água nos reservatórios (painel $c$ ) e a profundidade efetiva dos oceanos (painel $d$ ) tenham dependência bem baixa com a abundância de radioativos no manto.

As três maiores abundâncias, de 100\% (Terra), 150\% e 200\%, estão bem próximas e até parecem convergir, indicando que talvez não houvesse muito a se ganhar em habitabilidade aumentando a abundância de radioativos muito além da abundância terrestre. No entanto, as abundâncias mais baixas, de $50 \%$ e de $10 \%$ estão mais distantes das outras e indicam menor habitabilidade de maneira considerável. Então haveria mais a se ganhar evitando abundâncias de radioativos menores do que a terrestre do que procurando por abundâncias maiores.

Focando no manto (Figura 3.8), como com a massa planetária, a menor abundância de material radioativo implica em menores indicadores de atividade geológica e queda rápida no fluxo convectivo (painel $d$ ), taxa de expansão (painel $e$ ), número de Rayleigh (painel $h$ ) e no aumento mais rápido da viscosidade (painel $f$ ). A diferença entre os resultados de cada abundância é bem grande no modelamento do manto, mas isso é traduzido em menor intensidade quando pensado na questão de habitabilidade com $P_{\mathrm{CO}_{2}}$ e $T_{s}$. 


\section{Variação da Abundância de Radioativos}
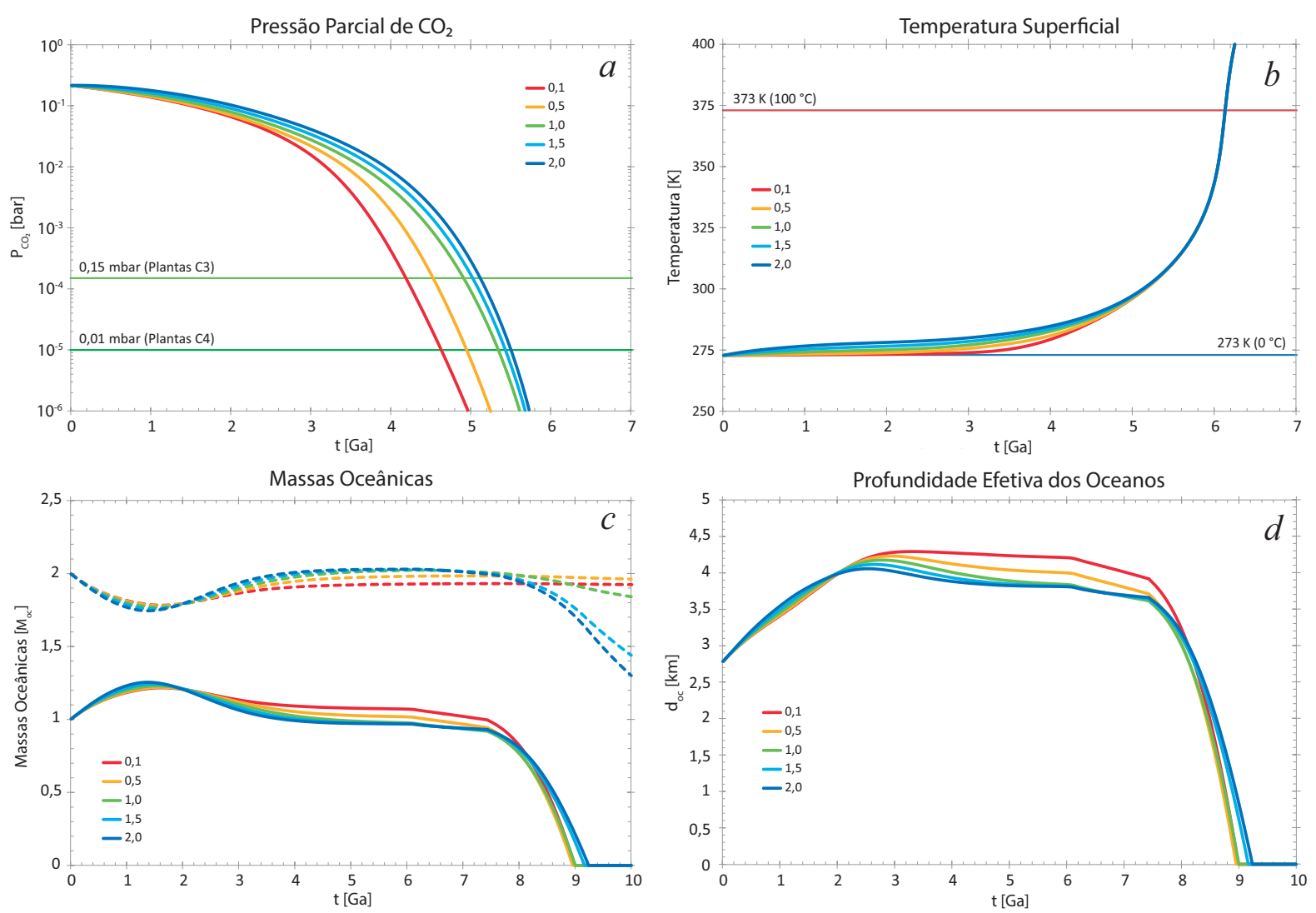

Figura 3.7: Resultados principais do modelo para a variação da abundância inicial de material radioativo no manto mantendo os outros parâmetros fixos, então para um planeta de 1,0 $\mathrm{M}_{\oplus}$. Valores da legenda indicam um valor multiplicativo do valor básico, então 0,5 indica 50\%. No painel $c$ as linhas cheias indicam o valor para os oceanos e as linhas tracejadas para o manto.

O efeito aqui quanto ao agrupamento das curvas é, em geral, o contrário da Figura anterior (3.7), com as curvas de $10 \%$ e $50 \%$ de abundância mais próximas entre si do que das outras. A razão de Urey (painel $g$ ) mostra que a contribuição da produção radioativo para o fluxo convectivo total é mínima para a abundância de 10\%. Então quase não haveria diferença de zero material radioativo para só $10 \%$. Com a proximidade da curva de $50 \%$ da curva de 10\%, parece que a abundância terrestre estaria próxima de alguma mudança comportamental importante. Pelo painel $c$, as duas curvas de menor abundância não teriam nenhum período de aquecimento inicial, apenas esfriariam, e tenderiam assintoticamente bem mais rápido para $d T_{m} / d T=0$. Abundâncias de radioativos algo menores do que a terrestre parecem já diminuir bastante a atividade interna do planeta. 


\section{Variação da Abundância de Radioativos}
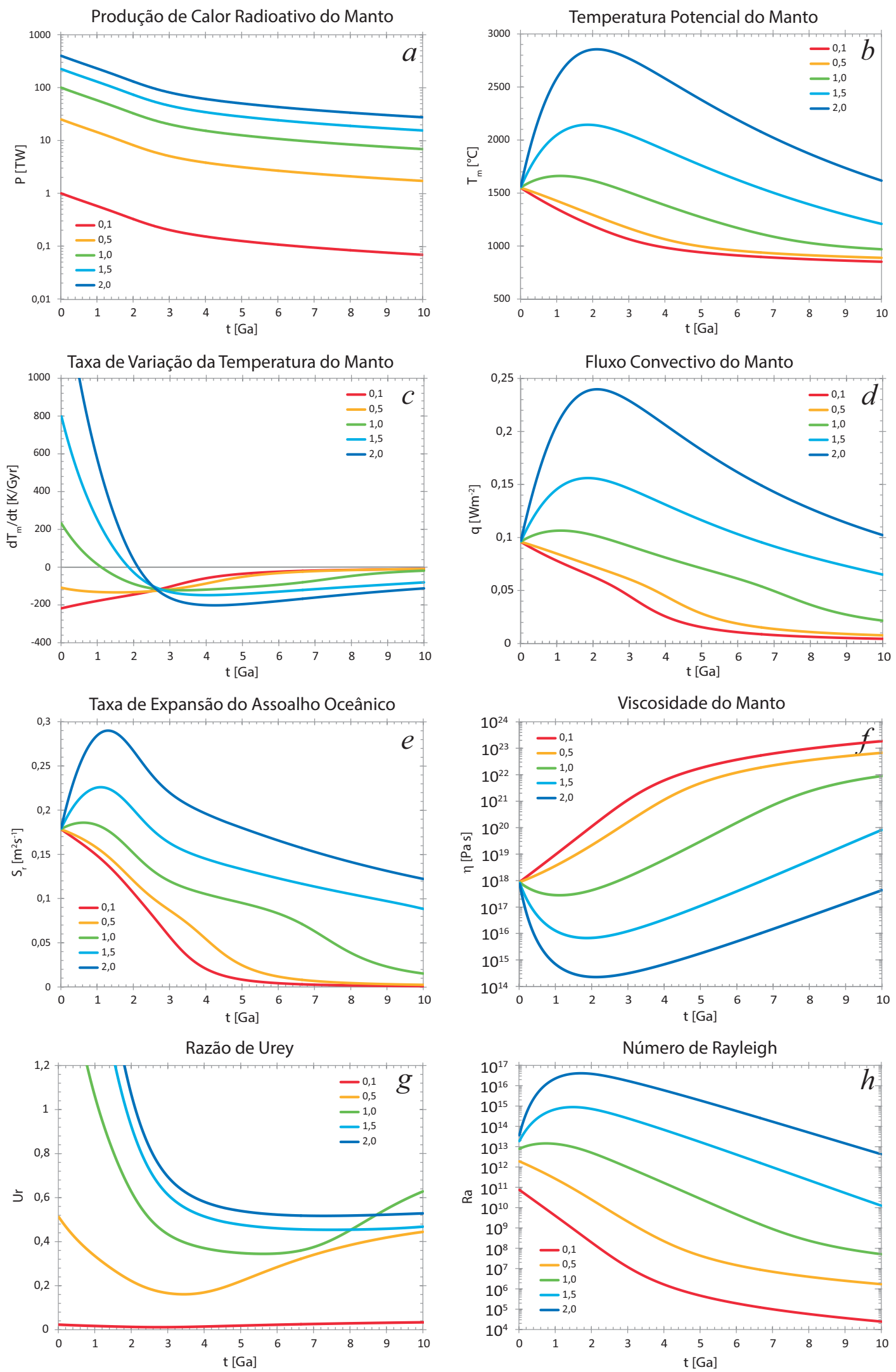

Figura 3.8: Resultados do modelo para a variação da abundância inicial de material radioativo no manto mantendo os outros parâmetros fixos, então para um planeta de 1,0 $\mathrm{M}_{\oplus}$. Valores da legenda indicam valor multiplicativo do valor inicial, então 0,5 indica $50 \%$. 
Tanto aqui quanto na variação da massa planetária a temperatura potencial do manto para o caso mais extremo $\left(4,0 \mathrm{M}_{\oplus}\right.$ ou $\left.200 \%\right)$ chegou a mais de $1800{ }^{\circ} \mathrm{C}$ e não sabemos se isso é alto demais e "não físico" ou se seria um resultado aceitável. Pode ser que tais temperaturas mudassem a física e comportamento do manto e tivéssemos de considerar isso. Então é indicada alguma cautela com relação a nossos resultados nessas altas temperaturas.

Falamos de maneira geral em "material radioativo", mas este é constituído de isótopos. Dos quatro considerados neste trabalho, potássio e tório podem ser observados por espectroscopia em estrelas e servir de indicativo de suas abundâncias em seus respectivos exoplanetas. Porém, teríamos acesso à abundância da soma dos isótopos ${ }^{39} \mathrm{~K},{ }^{40} \mathrm{~K}$ e ${ }^{41} \mathrm{~K}$, e

não só de ${ }^{40} \mathrm{~K}$, que é o do nosso interesse (Gonzalez et al., 2001). Como ${ }^{232} \mathrm{Th}$ é o isótopo de tório de maior meia-vida e o mais abundante, então seria mais facilmente separado de seus outros isótopos e de ser observado, servindo de aproximador para a abundância de material radioativo total em exoplanetas.

Voltando à Figura 2.1, ${ }^{40} \mathrm{~K}$ e ${ }^{235} \mathrm{U}$ foram os ispótopos de longas meias-vidas mais importantes em produção radioativa nos primeiros bilhões de anos da Terra (os de meias-vidas curtas teriam dominado bem inicialmente), $c 0 m{ }^{238} \mathrm{U}$ e ${ }^{232} \mathrm{Th}$ dominando mais tardiamente. Pode ser que a abundância relativa entre esses isótopos seja diferente em outros planetas e isso influencie em sua atividade interna e habitabilidade em curto e longo prazo. Mas, somente usando ${ }^{232} \mathrm{Th}$, medidas em gêmeas solares do disco fino da Galáxia (Botelho et al., 2018) indicam que essas estrelas seriam em média até mais ricas em tório do que o Sol na sequência principal de idade zero (zero age main sequence - ZAMS), permitindo um interior planetário ativo e um manto convectivo, possibilitando manter a habitabilidade por longas escalas de tempo.

\subsection{Conclusões Parciais}

Há muitas limitações em nossa abordagem, com possíveis escalonamentos desconhecidos ou variações desconhecidas ao modificar os parâmetros, além do não modelamento de alguns fenômenos que poderiam influenciar em alguns dos planetas simulados, como os de baixa massa. Mesmo assim, nossos resultados sugerem que tanto planetas mais massivos do que a Terra quanto planetas com maior abundância de material radioativo teriam maior facilidade em manter um manto convectivo e a habitabilidade por longos períodos de tempo. Essa 
vantagem, no entanto, não seria muito grande para massas planetárias maiores do que a da Terra ou abundâncias maiores do que a terrestre. Então talvez fosse mais o caso de evitar planetas de baixa massa e de pouca abundância de material radioativo do que de se esforçar para procurar somente por superterras ou por superabundâncias de radioativos. 
Capítulo 4

\section{Habitabilidade Estelar}

O modelo desenvolvido nos capítulos anteriores nos permitiu delimitar a ZHC no Sistema Solar e ao redor de outras estrelas. Fizemos isso selecionando uma massa estelar e executando o modelo para diferentes fluxos, então simulando diferentes distâncias à estrela, ao longo do tempo e para diferentes massas planetárias. A ZHC é dada pelo intervalo de semieixos maiores onde o planeta teria uma temperatura entre 273 e $373 \mathrm{~K}$. Alterando a massa estelar e repetindo o procedimento pudemos delimitar a ZHC em função da massa estelar, da massa planetária e da idade da estrela/planeta.

\subsection{Comparando Zonas Habitáveis}

A Figura 4.1 reúne a ZHC para o Sistema Solar atual segundo vários trabalhos da literatura. Felizmente, a órbita terrestre está dentro da ZHC segundo todos os trabalhos, em geral bem mais próxima do limite interior do que do exterior. O limite interior parece mais bem definido do que o exterior, que varia bastante de referência para referência. Lembrando-se dos resultados de capítulos anteriores, isso não é tão misterioso. O limite interno da ZHC é definido pelo aumento das temperaturas, efeito estufa desenfreado e pela perda de água. À despeito do papel das nuvens, esses eventos são quase que independentes de muitos parâmetros do planeta, dependendo mais da simples existência de grandes quantidades de água na superfície, alguma atmosfera e um alto fluxo estelar. Os trabalhos que conseguem empurrar o limite interno mais para perto do Sol exploram o papel das nuvens (Selsis et al., 2007; Zsom et al., 2013) ou a simples redução na quantidade de água superficial (Abe et al., 2011), impedindo o efeito estufa de passar de um certo ponto.

O limite externo depende, tradicionalmente, do efeito estufa e do coquetel de gases 
que irá mantê-lo. Como esses podem variar grandemente ao longo do tempo, da atividade geológica no planeta e da constituição do planeta, o limite exterior é mais facilmente variável com os parâmetros específicos escolhidos para cada planeta em cada modelo.

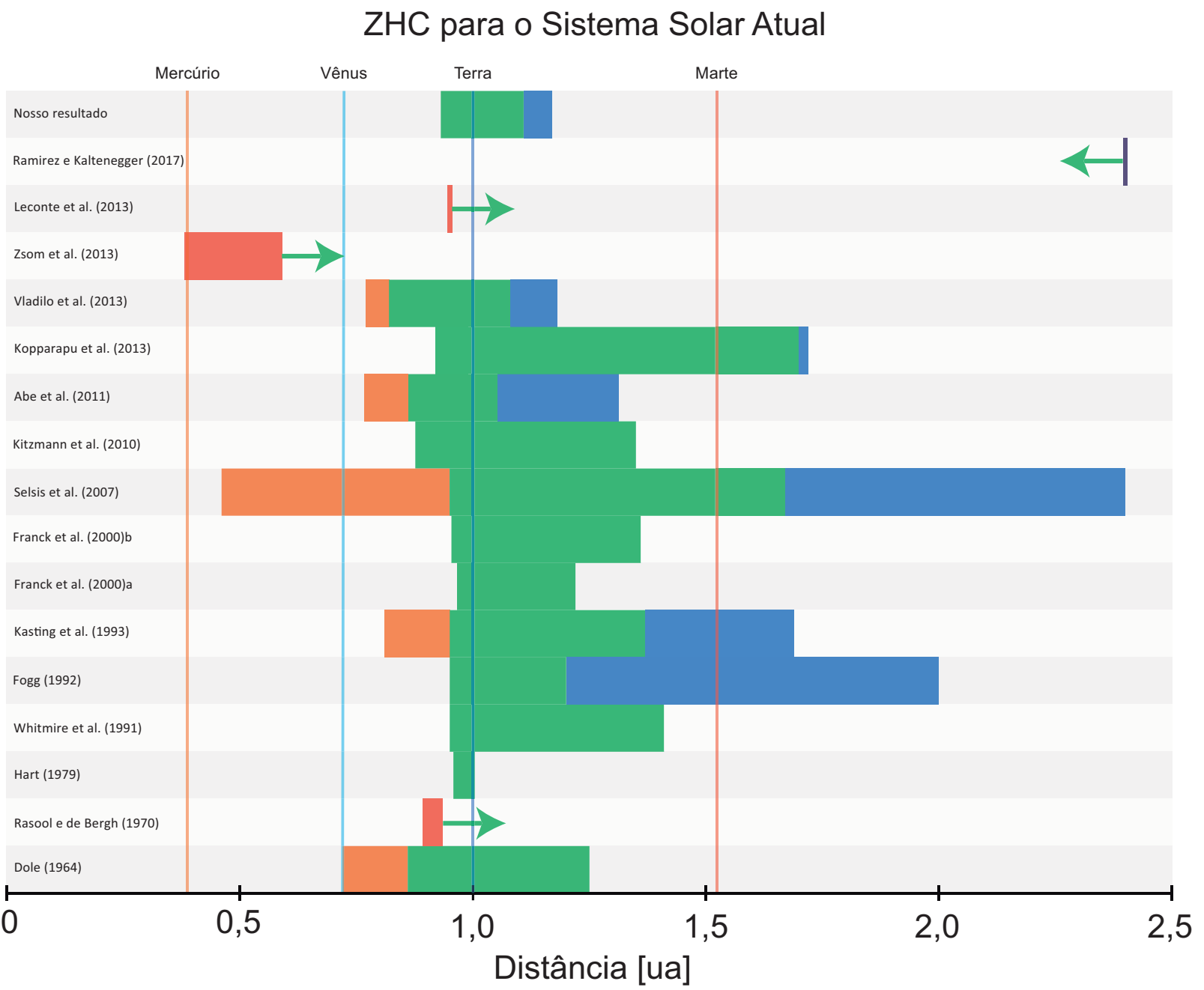

Figura 4.1: Comparação de resultados de trabalhos da literatura para os limites da ZHC para o Sistema Solar atual. Regiões verdes são os limites para o modelo básico dos trabalhos, um planeta bem parecido com a Terra. Regiões laranjas e azuis são os limites variando os parâmetros dos modelos e modelando planetas rochosos diferentes da Terra. Regiões vermelhas e azul escuro (com setas) indicam limites, respectivamente, mínimos e máximo da ZHC. Para maiores informações a respeito dos modelos e caracterização das ZHC procurar cada trabalho. As linhas verticais marcam os semieixos maiores das órbitas dos planetas interiores.

Nossa ZHC tem uma largura modesta frente às outras e o ganho em limite externo, região azul, foi ao aumentar a massa planetária. Esse resultado é esperado por causa das limitações geofísicas ao quanto de $\mathrm{CO}_{2}$, em escala secular, um planeta conseguiria manter em sua atmosfera. Considerar a geofísica do planeta e seus parâmetros planetários (massa, idade, quantidade de voláteis e material radiativo) parece limitar consideravelmente o limite 
exterior da ZHC tradicional. Podemos ver melhor isso na Figura 4.2.
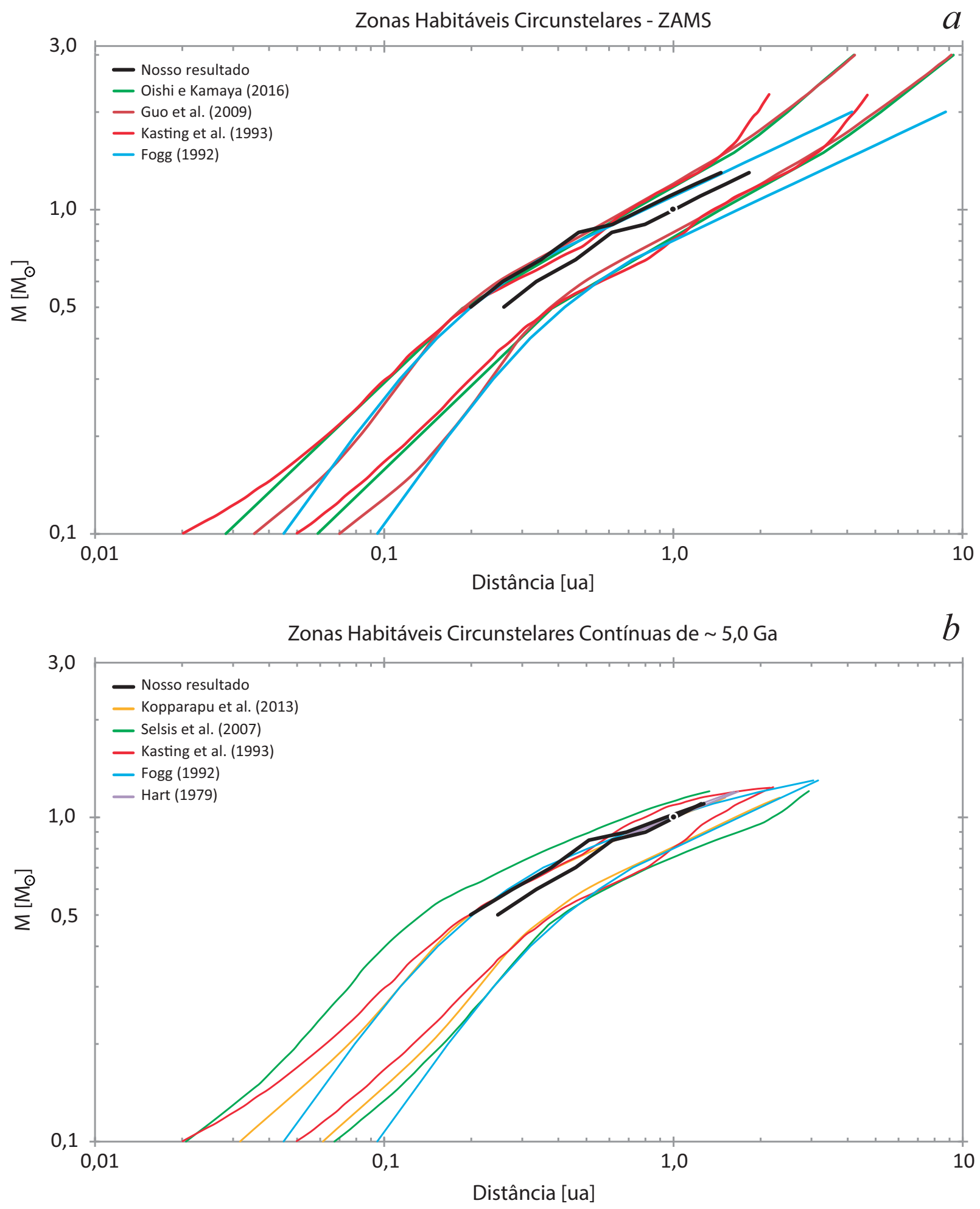

Figura 4.2: Comparação dos resultados de diferentes trabalhos da literatura para os limites da ZHC para um planeta semelhante à Terra. a) os limites para a sequência principal de idade zero (zero age main sequence - ZAMS). b) limites para a ZHC contínua de 4-5 Ga. Sol/Terra estão marcados como um ponto preto de contorno branco. 
Aqui são apresentados os limites interno e externo da ZHC para um planeta terrestre, parecido com a Terra segundo o modelo básico ou padrão de cada trabalho. Alguns trabalhos constam em apenas um dos dois painéis por não apresentarem ambas as situações, da ZHC na ZAMS e da ZHC contínua de $4-5 \mathrm{Ga}^{1}$. Os limites coincidem bem para o intervalo 0,5-1,0 $\mathrm{M}_{\odot}$ no caso na ZAMS, mas divergem consideravelmente para longe desse intervalo de massas, principalmente para baixas massas. Nossa ZHC é a mais estreita, com a Terra no limite exterior da ZHC na ZAMS. Nosso limite interno, no entanto, coincide com as outras curvas. No caso da ZHC contínua vemos que a largura e posição da ZHC permanecem basicamente inalteradas em baixas massas, já que a luminosidade da estrela pouco se altera em 4-5 Ga, mas se estreita a partir de $\sim 0,8 \mathrm{M}_{\odot}$ e mesmo é inexistente acima de 1,1 $\mathrm{M}_{\odot}$, pela evolução mais rápido das estrelas de maior massa. Novamente nossa ZHC é a mais estreita, mas a situação é mais grave com os limites bem próximos da Terra.

Hart (1979) apresenta uma ZHC ainda mais estreita do que a nossa, mas ele teve o problema de não ter usado o ciclo do carbono para estabilizar o clima em seu modelo, nós temos um estabilizador por ciclo do carbono em nosso modelo, a estreiteza de nossa ZHC é pela limitação do acúmulo de $\mathrm{CO}_{2}$ na atmosfera considerando escalas seculares de tempo. Como discutido antes, a Terra primitiva contaria com um coquetel de gases estufa em sua atmosfera além de água e dióxido de carbono que poderia ter contribuído em aumentar a temperatura e, no caso do cálculo da ZHC, ter expandido o limite externo e alargado a ZHC. O problema do Sol jovem fraco ainda não foi bem resolvido e, como nos atemos apenas a água e dióxido de carbono como gases estufa, não pudemos explorar muito bem outras possíveis soluções para o problema.

Nossos indicativos de que apenas água e dióxido de carbono não conseguiriam manter a Terra quente o suficiente no passado distante, porque seria preciso $\mathrm{CO}_{2}$ acima do que as evidências geoquímicas indicam, levam-nos a crer que outros fatores podem estar agindo e a ZHC tradicional parece precisar de alguma atualização.

\footnotetext{
${ }^{1}$ Como a luminosidade da estrela aumenta com o passar do tempo, a ZHC se moveria para fora e ficaria mais larga. A ZHC contínua é a região continuamente dentro da ZHC pelo intervalo de tempo especificado a partir da ZAMS.
} 


\subsection{Zona Habitável Circunstelar no Tempo e no Espaço}

A Figura 4.3 reúne as informações de largura e posição da ZHC no tempo, e informações a respeito do tipo de habitabilidade, qual espaço de parâmetros tem temperaturas habitáveis (região vermelha mais verde), níveis de $\mathrm{CO}_{2}$ habitáveis para plantas $\mathrm{C} 4$ (região cinza mais verde) e a intersecção dos dois (região verde), o espaço mais habitável.

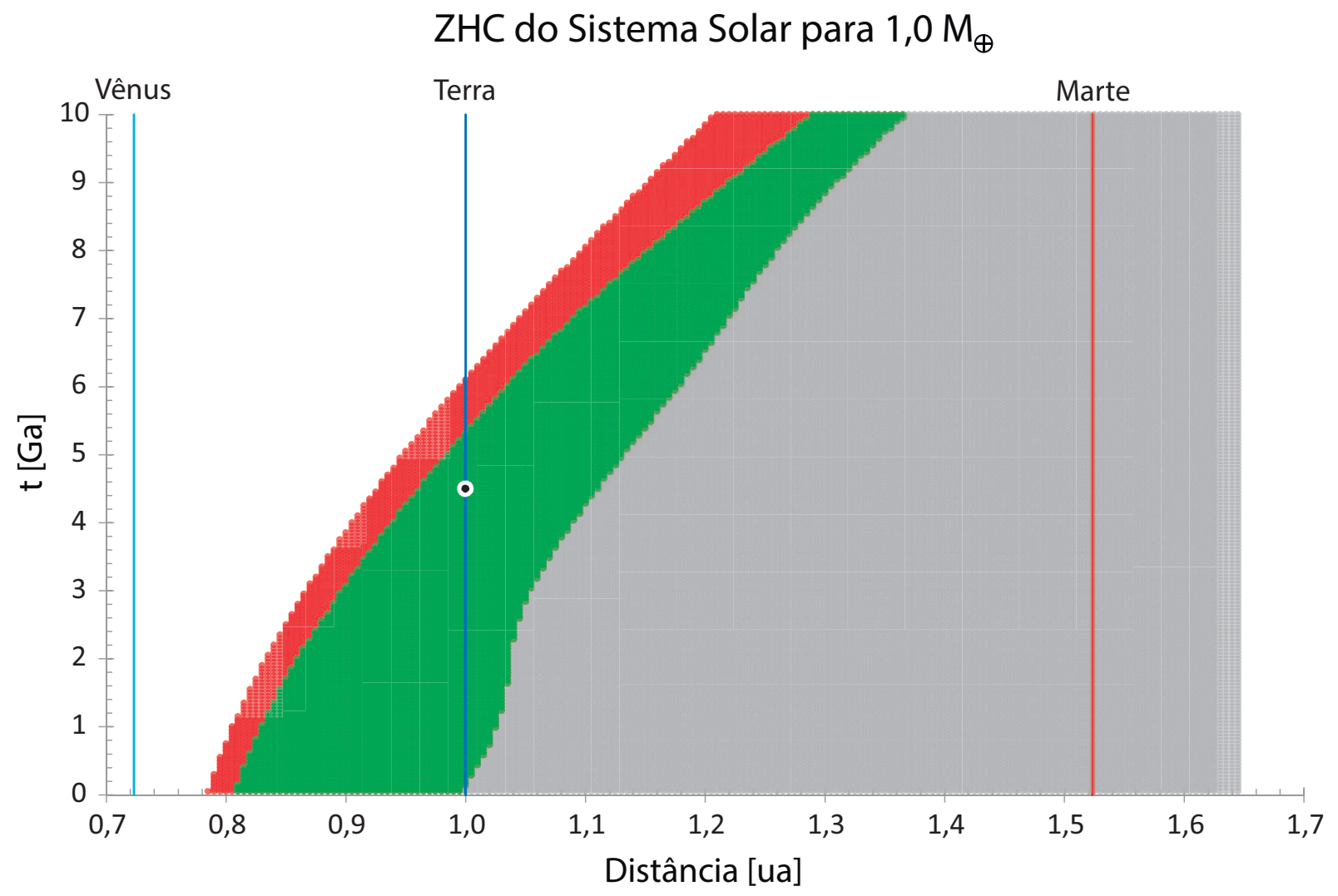

Figura 4.3: ZHC para um planeta de 1,0 $\mathrm{M}_{\oplus}$ no Sistema Solar ao longo do tempo. A região verde delimita um espaço de parâmetros com temperaturas habitáveis (273-373 K) e uma pressão parcial de $\mathrm{CO}_{2}$ acima de 0,01 mbar. A região vermelha é onde $P_{\mathrm{CO}_{2}}$ está abaixo de 0,01 mbar, mas a temperatura superficial está no intervalo habitável. A região cinza é $P_{\mathrm{CO}_{2}}$ está acima de 0,01 mbar, mas a temperatura superficial está fora do intervalo habitável. A Terra atual é marcada por um ponto preto de contorno branco.

O comportamento mais simples esperado da ZHC é que, ao longo do tempo, ela se desloque para longe da estrela e se torne mais larga por causa do aumento da luminosidade da estrela ao longo do tempo. Mas não é bem isso o que encontramos. A ZHC se desloca para longe da estrela, mas tanto a ZHC, limitada pela temperatura, quanto a mais restrita, da região verde, são mais largas quando o planeta é jovem do que quando ele é mais velho. A ZHC mais restrita chega até a ficar com metade da largura que tinha inicialmente. Isso é devido à queda nos níveis de $\mathrm{CO}_{2}$ e no retrocesso do limite externo da ZHC. Vemos 
isso também no aumento da largura da região vermelha. Altas temperaturas aumentam as intempéries, retirando $\mathrm{CO}_{2}$ da atmosfera. Conforme o planeta envelhece e esfria, fica cada vez mais difícil manter tanto $P_{\mathrm{CO}_{2}}$ na atmosfera, fazendo com que seja cada vez mais fácil atingir o limite de plantas $\mathrm{C} 4$. O limite interno é uma curva mais suave, mas o limite externo tem algumas ondulações oriundas de variações na atividade geológica do planeta.

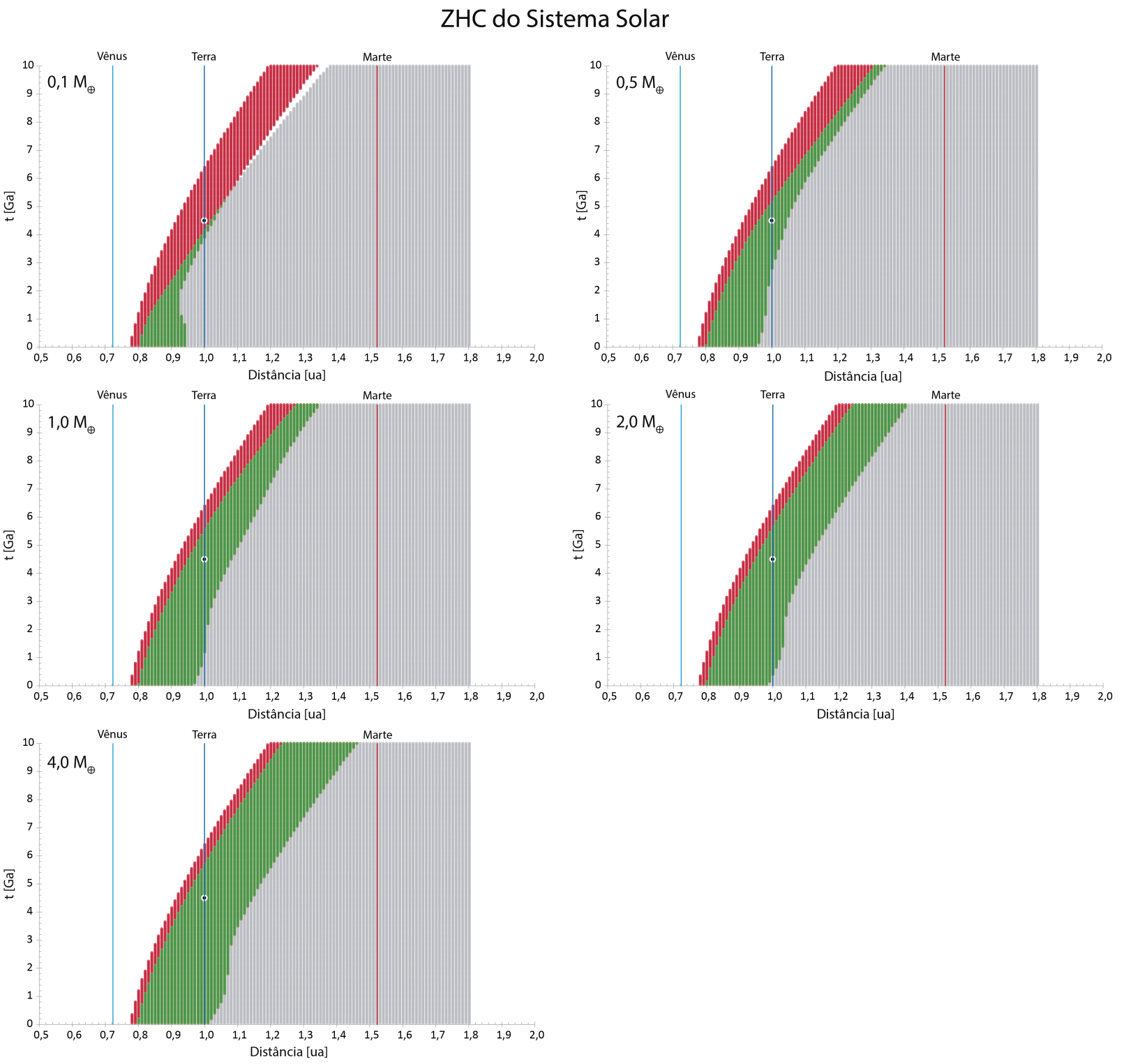

Figura 4.4: ZHC para planetas de diferentes massas no Sistema Solar ao longo do tempo. O código de cores é o mesmo que na Figura 4.3. Aqui, partimos o modelo de $t_{*}=0$, então sem aquele atraso de $70 \mathrm{Ma}$. Isso alterou um pouco o resultado inicial para $1,0 \mathrm{M}_{\oplus}$.

Retorne para algum gráfico da temperatura potencial do manto (por exemplo, a Figura 3.5b) e observe o caso terrestre, ele contém três regiões distintas: um pequeno aquecimento inicial, uma longa queda, e uma última região de suavização na queda da temperatura. 
Vemos o efeito disso na largura da ZHC e mais claramente na largura da região verde ao longo do tempo. Variar a massa planetária, e então os parâmetros internos do planeta, pode dar uma ideia melhor disso. A Figura 4.4 reúne os resultados para as cinco massas planetárias estudadas assim como na Figura 4.3.

Observando a Figura 4.4 percebemos que a largura da ZHC é maior conforme maior for a massa do planeta. A região verde no caso da massa de $0,1 \mathrm{M}_{\oplus}$ é até inexistente após $t \sim 5$ Ga. O que expande a largura da ZHC é o limite externo, porque o interno permanece no mesmo lugar em todos os cinco casos. Retorne para os gráficos de temperatura superficial do capítulo anterior (Figuras $3.4 a$ e $3.7 a$ ) e veja como as curvas de $T_{s}$ convergem para temperaturas altas. Em nosso modelo a ZHC só pode ser expandida para longe da estrela, para regiões mais frias e isso é feito mantendo mais $\mathrm{CO}_{2}$ na atmosfera, o que, por sua vez, é realizado mantendo um manto mais quente por mais tempo. A influência da evolução térmica do planeta na habitabilidade fica mais clara aqui.

Comparando a ZHC das diferentes massas vemos que Vênus nunca foi habitável. Isso contrasta com o limite interno otimista da ZHC, que parte da existência de água líquida em Vênus no passado (Kasting et al., 1993). As já muito mencionadas nuvens podem ajudar a empurrar o limite interno para a órbita de Vênus nos primórdios do Sistema Solar, mas a habitabilidade seria breve. Marte, com 0,107 $\mathrm{M}_{\oplus}$, também não seria habitável em nenhum momento e isso não está de acordo com as evidências de água líquida na superfície marciana bilhões de anos atrás. Isso deve ser o efeito do que já discutimos, sobre o menor papel do $\mathrm{CO}_{2}$ levando em conta a evolução térmica do planeta, outros fenômenos e o coquetel de gases estufa que poderia ter aquecido não só a Terra inicialmente como outros planetas rochosos. Não cobrimos isso aqui, mas vemos que Marte provavelmente perderia sua habitabilidade em pouco tempo por esfriar rapidamente. Com isso também poderia perder um forte campo magnético, pela solidificação do núcleo externo, o que propiciaria a perda mais rápida de atmosfera. 


\section{ZHC por Massa Estelar}
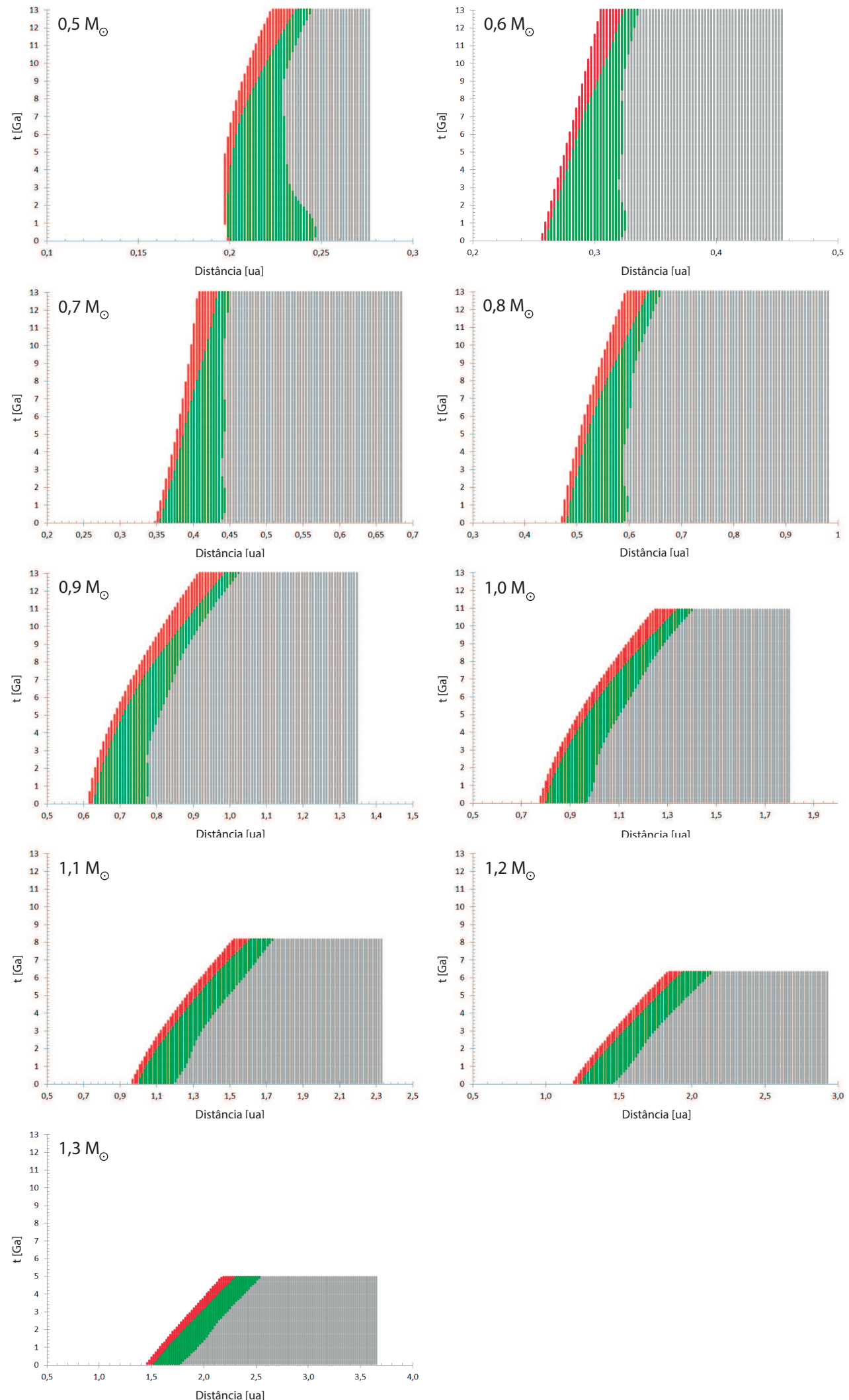

Figura 4.5: ZHC para um planeta de 1,0 $\mathrm{M}_{\oplus}$ para estrelas de diferentes massas ao longo do tempo. O código de cores é o mesmo que na Figura 4.3. 
A Figura 4.5 exibe o mesmo que as duas figuras anteriores, mas dessa vez fixamos a massa planetária em 1,0 $\mathrm{M}_{\oplus}$ e variamos a massa estelar. A inclinação dos limites da ZHC em cada painel não diz muito, porque a largura da ZHC para a estrela de $0,5 \mathrm{M}_{\odot}$ está muito mais perto da estrela e é muito mais estreita do que a de massa $1,3 \mathrm{M}_{\odot}$ e não havia uma escala única para melhor comparar todos os conjuntos de dados sem comprimir a escala horizontal da menor massa estelar até sua ZHC se tornar uma linha vertical.

Nesse capítulo, utilizamos a simples equação 4.1 de Hansen et al. (2012) para determinar quanto tempo, $\tau_{S P}$, as estrelas passam na sequência principal:

$$
\tau_{S P}=10 G a \times\left(\frac{M_{*}}{M_{\odot}}\right)^{-2,5} .
$$

No capítulo seguinte, utilizamos uma equação diferente para o tempo de vida das estrelas na sequência principal (equação 5.4), porque utilizamos um modelo da evolução química da Galáxia e esse usa uma equação diferente para $\tau_{S P}$.

\subsection{Largura da Zona Habitável Circunstelar}

A Figura 4.6 exibe a largura da ZHC de maneira a deixar mais claros os efeitos da evolução térmica do planeta e da luminosidade estelar em relação à massa estelar, massa planetária e do tempo. Podemos ver que planetas de massa menor têm ZHC sistematicamente mais estreitas e que as ZHC ficam mais largas com a massa estelar. O comportamento ao longo do tempo é mais complexo. Um planeta pouco massivo irá esfriar e perder rápido seu ciclo do carbono estabilizante, ficando mais à mercê da luminosidade estelar para manter sua habitabilidade, isso faz com que sua ZHC, mais larga inicialmente, se estreite até a largura que depende pouco do planeta e mais da estrela. Em estrelas de baixa massa, com evolução lenta, a ZHC não se moverá muito, já que a luminosidade não aumenta significativamente durante o período de $\sim 10 \mathrm{Ga}$. Em estrelas de alta massa, a evolução é rápida e a ZHC migra para longe da estrela, ficando mais larga. Foque no painel inferior, para um planeta de $0,1 \mathrm{M}_{\oplus}$. A largura da ZHC é maior inicialmente, então cai conforme o manto do planeta esfria e menos $\mathrm{CO}_{2}$ é mantido na atmosfera, retrocedendo o limite exterior da ZHC. Em baixas massas estelares, a largura então fica algo constante, mas vai crescendo com a massa estelar, porque a estrela evolui mais rapidamente e também aumenta de luminosidade mais rapidamente. 
Agora, foque no painel superior, para um planeta de 4,0 $\mathrm{M}_{\oplus}$. Tendo um período de aquecimento inicial do manto, a largura da ZHC cresce no primeiro bilhão de anos para depois, com a queda na temperatura do manto, diminuir, mas suavemente, por esfriar devagar. Em baixas massas estelares, a evolução da estrela não tem um papel importante e só vemos o estreitamento da ZHC pelo resfriamento do planeta. Em altas massas, a estrela evolui rápido e a ZHC acaba crescendo com o tempo. O que há então é uma composição de dois fenômenos: o manto do planeta se resfriando (ou tendo um pequeno aquecimento inicial para depois se resfriar) e diminuindo a largura da ZHC, e a estrela evoluindo, aumentando de luminosidade, e alargando a ZHC. Dependendo da combinação da massa estelar e planetária o resultado é diferente.

No capítulo seguinte, usaremos a largura da ZHC para explorar as regiões habitáveis em nossa Galáxia. Para isso faremos uma abordagem um pouco mais frequentista e precisamos saber a frequência de planetas de massas diferentes, qual massa planetária seria mais comum. Como, na mesma categoria, coisas pequenas costumam ser mais frequentes do que coisas grandes (Frank, 2016), há uma expectativa de que planetas de menor massa (e raio) sejam mais frequentes do que planetas mais massivos (e de maior raio). Essa expectativa parece ser respaldada por alguns trabalhos (Marcy et al., 2005; Youdin, 2011; Howard et al., 2012; Dong e Zhu, 2013) que descrevem uma distribuição em raio dada por uma lei de potência de expoente $\sim-1,8$, para exoplanetas de raios algo menores do que o terrestre até algo como superterras ou netunianos. Esses resultados são limitados no número de exoplanetas que contém e em seus parâmetros, muitas vezes com períodos curtos, então é difícil generalizar com confiança, mas é o melhor que podemos fazer. Aqui, vamos assumir uma frequência dada por Youdin (2011):

$$
\frac{d f}{d R} \propto\left(\frac{R}{R_{\oplus}}\right)^{-1,73} .
$$

Usando a relação massa-raio de Fortney et al. (2007) atrelamos frequências relativas a planetas telúricos de massas diferentes. Supondo que para um planeta de massa $0,1 \mathrm{M}_{\oplus} \mathrm{a}$ frequência seja 1,0, para as outras massas, 0,5, 1,0, 2,0 e 4,0 $\mathrm{M}_{\oplus}$, são, respectivamente, 0,42, 0,29, 0,21 e 0,16. Então uma superterra de 4,0 $\mathrm{M}_{\oplus}$ teria uma frequência de apenas algo como 1/6 daquela de uma pequeno planeta como Marte. Planetas menos massivos seriam mais frequentes, o que é ruim pensando em habitabilidade, por conta de tudo discutido 


\section{Largura da ZHC no Tempo por Massa Planetária}

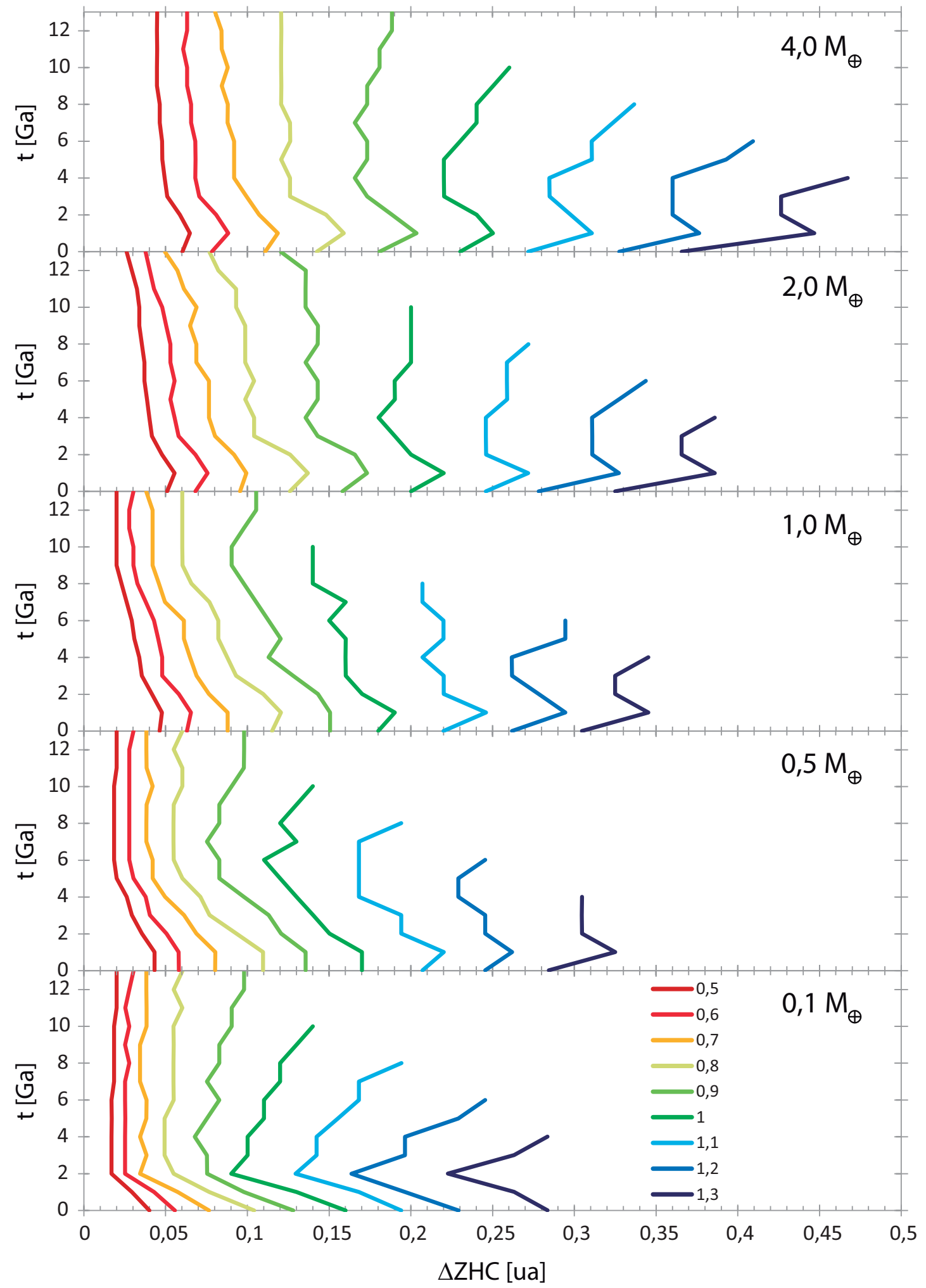

Figura 4.6: Largura da ZHC em ua para diferentes massas planetárias e estelares ao longo do tempo. A legenda se refere à massa estelar em massas solares. 


\section{Largura Ponderada da ZHC no Tempo}

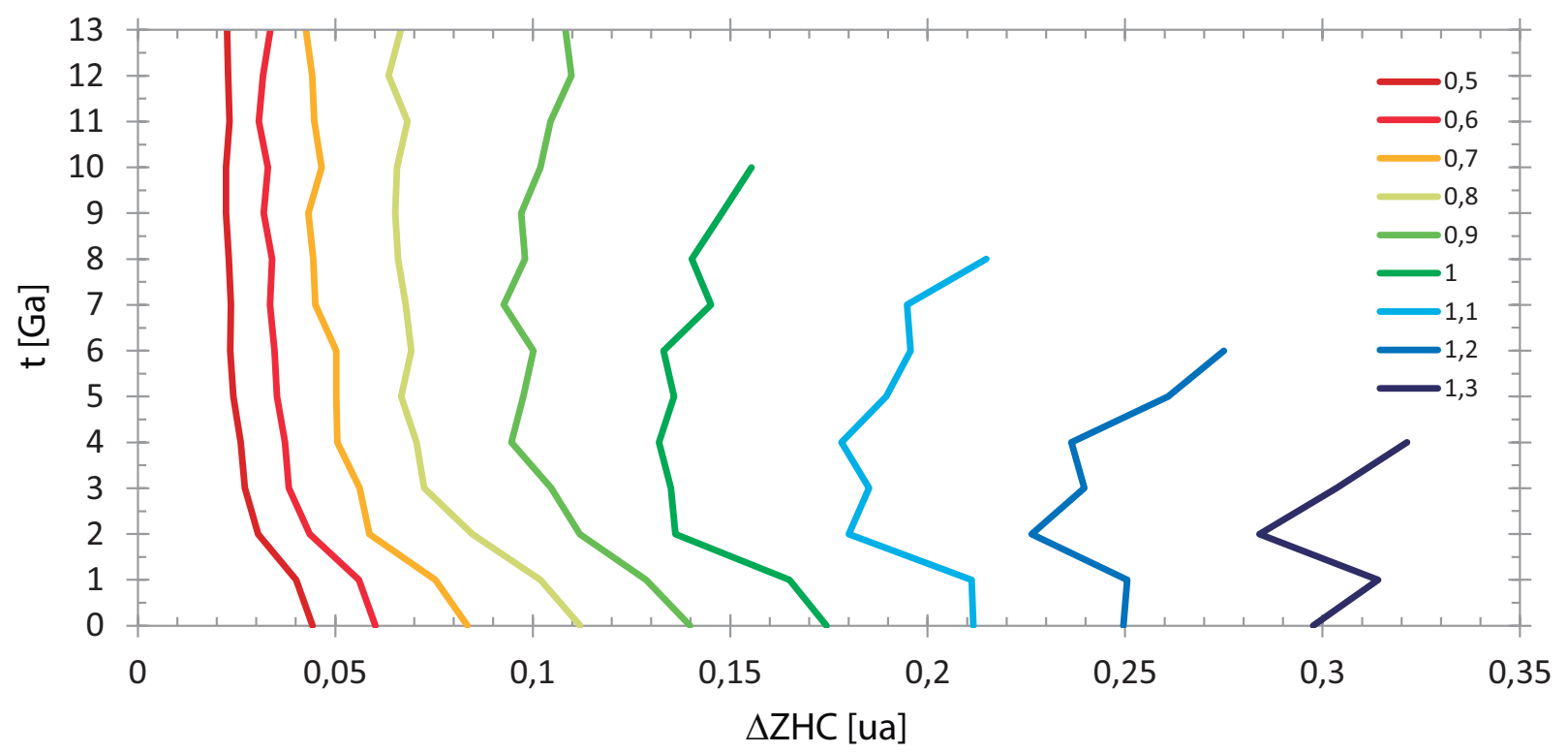

Figura 4.7: Largura da ZHC em ua ponderada pela massa planetária para diferentes massas planetárias e estelares ao longo do tempo. A legenda se refere à massa estelar em massas solares.

anteriormente. Fazendo uma média ponderada pela frequência por massa planetária dos resultados da Figura 4.6, temos a Figura 4.7. O comportamento é o mesmo descrito anteriormente, mas com peso maior das menores massas planetárias.

Para poder usar esse resultado mais adiante em nosso modelo de habitabilidade Galáctica precisamos de uma descrição mais sucinta e robusta dele, como um ajuste. Ajustamos uma lei de potência na massa estelar vezes uma exponencial no tempo obtendo:

$$
\Delta Z H C=0,1553(27) M_{*}^{2,695(57)} 10^{-0,00576(147) t_{*}} .
$$

O ajuste é mostrado na Figura 4.8. O comportamento é de que a ZHC é mais larga quanto maior a massa estelar e mais estreita quanto maior a idade da estrela/planeta. Estrelas mais massivas tem um tempo menor de estadia na sequência principal e são menos frequentes do que as de baixa massa, mas vamos discutir isso mais a seguir. 


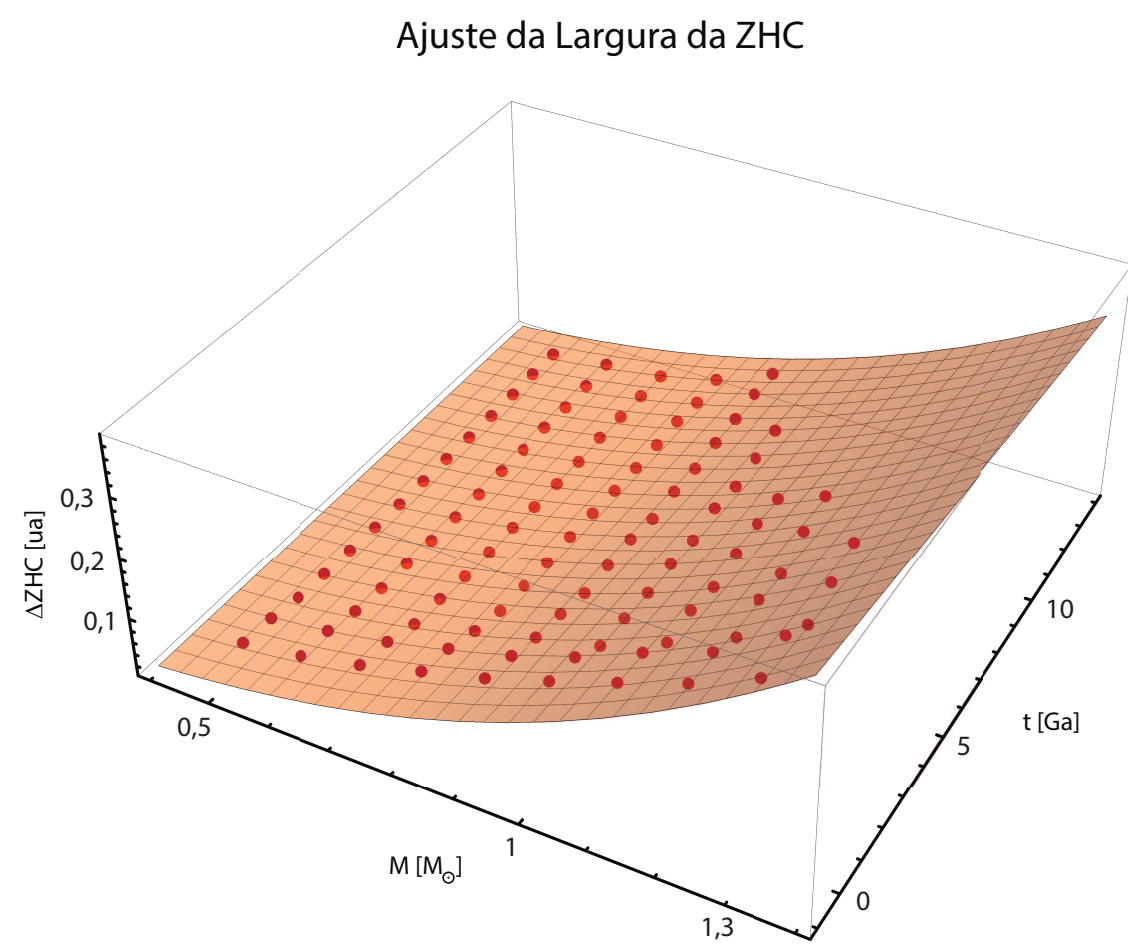

Figura 4.8: Ajuste de equação aos dados de largura ponderada da ZHC apresentados na Figura 4.7.

\subsection{Conclusões Parciais}

Nem sempre considerar mais - aumentar a complexidade - expandiria a ZHC. Considerar a atividade geológica de um planeta em sua habitabilidade parece limitar consideravelmente a extensão da ZHC tradicional por limitar quanto de $\mathrm{CO}_{2}$ poderia haver na atmosfera e por alterar a localização do limite externo da ZHC. A ZHC de planetas mais massivos seria mais larga e duraria por mais tempo, mas esses planetas talvez fossem menos frequentes do que os menos massivos. Ponderando pela massa planetária, a largura da ZHC aumentaria com a massa estelar e diminuiria com a idade da estrela/planeta. A ZHC tradicional parece precisar de alguma atualização e temos a oportunidade de explorar outros fatores que poderiam expandir a ZHC, como a evolução térmica do planeta, o albedo superficial, a área de cobertura e propriedades das nuvens, a pressão atmosférica total, e um coquetel de outros gases estufa que poderiam estar presentes na atmosfera. 
Capítulo 5

\section{Habitabilidade Galáctica}

Neste capítulo, utilizamos alguns dos resultados e ferramentas dos capítulos anteriores e desenvolvemos mais algumas ferramentas para analisar as melhores regiões de nossa Galáxia para procurar por planetas habitáveis.

\subsection{Fração de Estrelas com Planetas Telúricos}

Vários trabalhos estimaram a fração de estrelas com planetas com resultados variados dependendo da massa ou raio do planeta de interesse, da classe da estrela ou de outros fatores, como metalicidade da estrela. Planetas gigantes são mais frequentes quanto mais metálicas as estrelas (Santos et al., 2004; Fischer e Valenti, 2005; Sozzetti et al., 2009; Johnson et al., 2010; Mortier et al., 2013; Wang e Fischer, 2015), enquanto planetas rochosos podem não ter frequência dependente da metalicidade estelar (Buchhave et al., 2012) ou ter uma dependência mais fraca (Wang e Fischer, 2015). A frequência também parece estar ligada ao tipo espectral (e então massa) da estrela, tanto para planetas gigantes (Johnson et al., 2010), quanto para planetas rochosos (Dressing e Charbonneau, 2013; Wang e Fischer, 2015), com estrelas de mais alta temperatura efetiva (e maior massa) possuindo maior frequência de planetas. Johnson et al. (2010) determinaram a fração de estrelas com planetas gigantes, $f_{\text {gig }}$, em estrelas AFGKM com metalicidades $-0,6<[\mathrm{Fe} / \mathrm{H}]<0,8$ dex como um plano massa-metalicidade:

$$
f_{\text {gig }}=0,07(1) \times M_{*}^{1,0(3)} \times 10^{1,2(2)[\mathrm{Fe} / \mathrm{H}]} .
$$

Wang e Fischer (2015) estudaram estrelas do banco de dados do telescópio espacial Kepler com temperaturas efetivas entre $4800 \mathrm{~K}$ e $6500 \mathrm{~K}$ e não apresentaram frequências 
absolutas, mas indicaram que um plano massa-metalicidade pode existir não só para planetas gigantes como pode ser universal, para planetas de todas as massas. A Figura 5.1 exibe seus resultados mais importantes. Eles dividiram seu conjunto de dados em grupos de metalicidade (maior e menor) e temperatura efetiva (maior e menor) e fizeram a razão da frequência de exoplanetas de cada tipo (rochoso, anão gasoso, gigante gasoso) em cada grupo. Se, por exemplo, a frequência de exoplanetas rochosos não dependesse da metalicidade, a razão da frequência de exoplanetas do grupo de alta metalicidade pela frequência do grupo de baixa metalicidade deveria dar 1 dentro das incertezas. Mas todas as razões deram acima de 1 fora das incertezas. E quanto maior a diferença de metalicidade média em cada grupo maior ficava a razão.

Somando-se a isso, Zhu et al. (2016) mostraram que a discrepância entre trabalhos quanto a se a frequência de planetas rochosos seria correlacionada à metalicidade e à massa estelar poderia ser explicada por baixa eficiência e vieses nos métodos de detecção e por uma alta frequência de planetas pequenos, de maneira que uma frequência dada por uma relação na forma da equação 5.1 também seria possível para planetas rochosos.

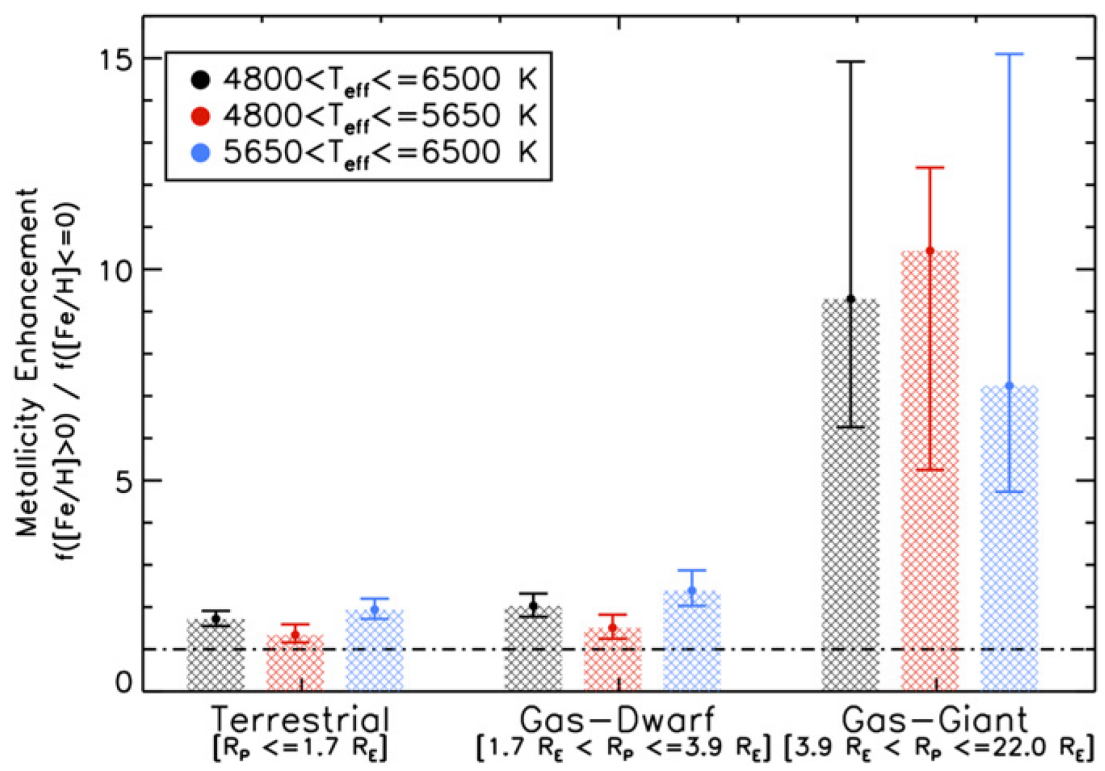

Figura 5.1: Figura 4 de Wang e Fischer (2015) retratando a taxa de ocorrência relativa de planetas de diferentes raios. A taxa de ocorrência relativa é a razão da taxa de ocorrência para estrelas ricas em metais por aquela de estrelas pobres em metais. A linha tracejada pontilhada indica o valor um, quando não há dependência da taxa de ocorrência com a metalicidade. As diferentes cores indicam intervalos de temperatura efetiva diferentes.

Dessa forma, assumimos uma relação na forma $f_{r}=a \times M_{*}{ }^{b} \times 10^{c[\mathrm{Fe} / \mathrm{H}]}$ para a frequência de planetas rochosos ao redor de estrelas FGK. Parte do ajuste dos coeficientes pôde ser 
feita com os resultados de Wang e Fischer (2015), mas esses são relativos e precisamos de uma frequência absoluta para a calibração.

A partir de dados do Kepler, Fressin et al. (2013) determinaram que 50\% das estrelas FGK teriam planetas detectáveis pelo Kepler com períodos de até 80 dias e com raios maiores do que $0,8 R_{\oplus}$. A fração para planetas com raios entre 0,8 e $1,25 R_{\oplus}$ seria de $\sim 16,5 \%$. Posteriormente essa fração foi revisada para baixo por Zhu et al. (2018), de maneira que $\sim 30 \%$ das estrelas FGK teriam planetas detectáveis pelo Kepler com períodos de até 400 dias e com raios maiores do que $\sim 1,0 R_{\oplus}$. Infelizmente, Zhu et al. (2018) não fornecem a fração para planetas rochosos em separado. A maioria dos planetas nessas amostras são de superterras e mininetunos, acima do intervalo de massas de nosso interesse, mas não seria uma aproximação muito grande dizer que é um indicativo para planetas "pequenos" (rochosos em geral). Por causa da limitação no período e em raio inferior, a fração total pode ser maior do que $30 \%$. Considerando isso, e sem poder fazer muito mais, aproximamos a frequência de exoplanetas telúricos pela frequência de exoplanetas rochosos e estimamos em 30\% a fração média de estrelas FGK com planetas telúricos.

De posse desse número, calibramos as razões de Wang e Fischer (2015) tirando a média entre o ponto médio de seus grupos de dados em metalicidade e temperatura efetiva, convertendo temperatura efetiva para massa estelar usando as relações de Habets e Heintze (1981) e Svechnikov e Taidakova (1984). Conseguimos dez pontos de dados com isso e ajustamos a função de massa-metalicidade descrita anteriormente, obtendo a função

$$
f_{\text {tel }}=0,276(6) \times M_{*}^{1,81(22)} \times 10^{0,379(28)[\mathrm{Fe} / \mathrm{H}]},
$$

apresentada na Figura 5.2.

A Figura 5.3 apresenta nosso ajuste (linhas cheias) e a equação 5.1 de Johnson et al. (2010) para planetas gigantes (linhas pontilhadas), além da subtração das duas (linhas tracejadas). Temos o resultado básico de que a fração de estrelas FGK, com planetas telúricos, cresce com a metalicidade e com a massa da estrela. A dependência da fração com as variáveis é bem mais fraca em metalicidade do que para planetas gigantes, que cresce bem rápido, mas é forte na massa estelar. 


\section{Ajuste da Fração de Estrelas com Planetas Telúricos}

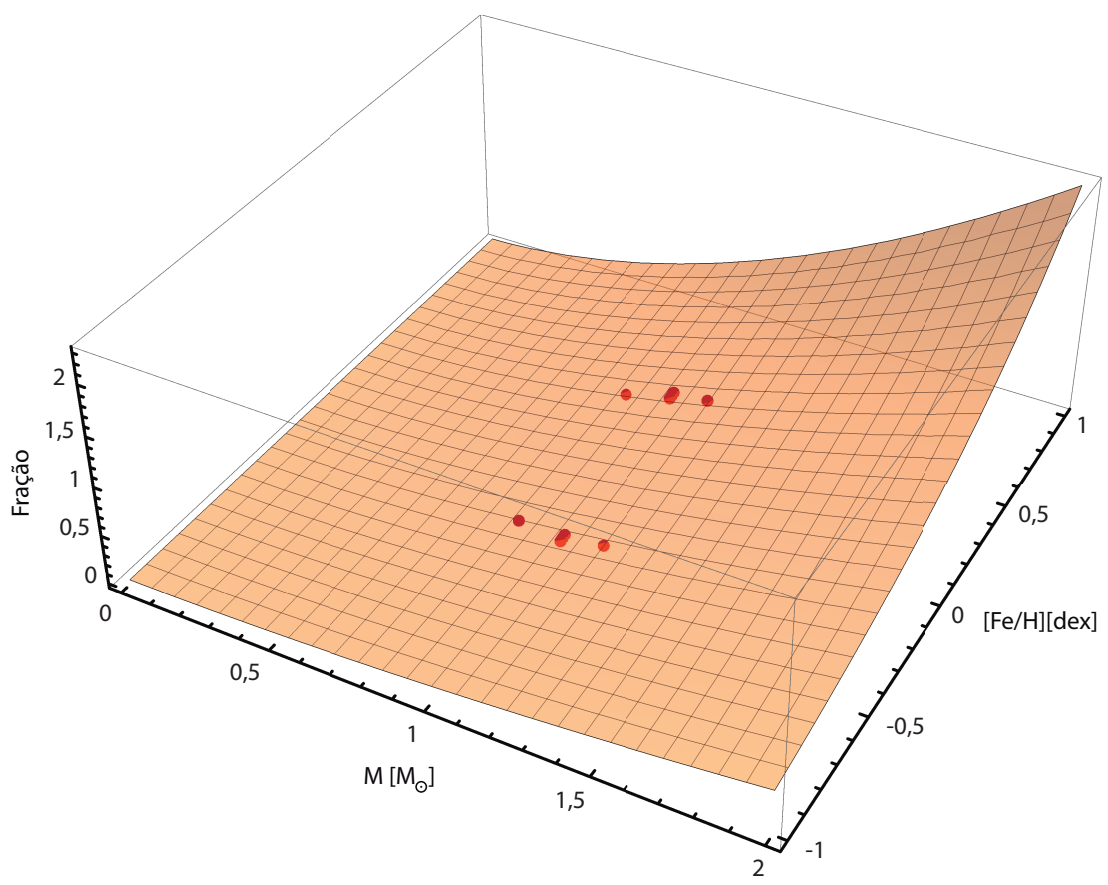

Figura 5.2: Ajuste da equação $f_{r}=a \times M_{*}{ }^{b} \times 10^{c[\mathrm{Fe} / \mathrm{H}]}$ às estimativas da fração de estrelas FGK com planetas telúricos.

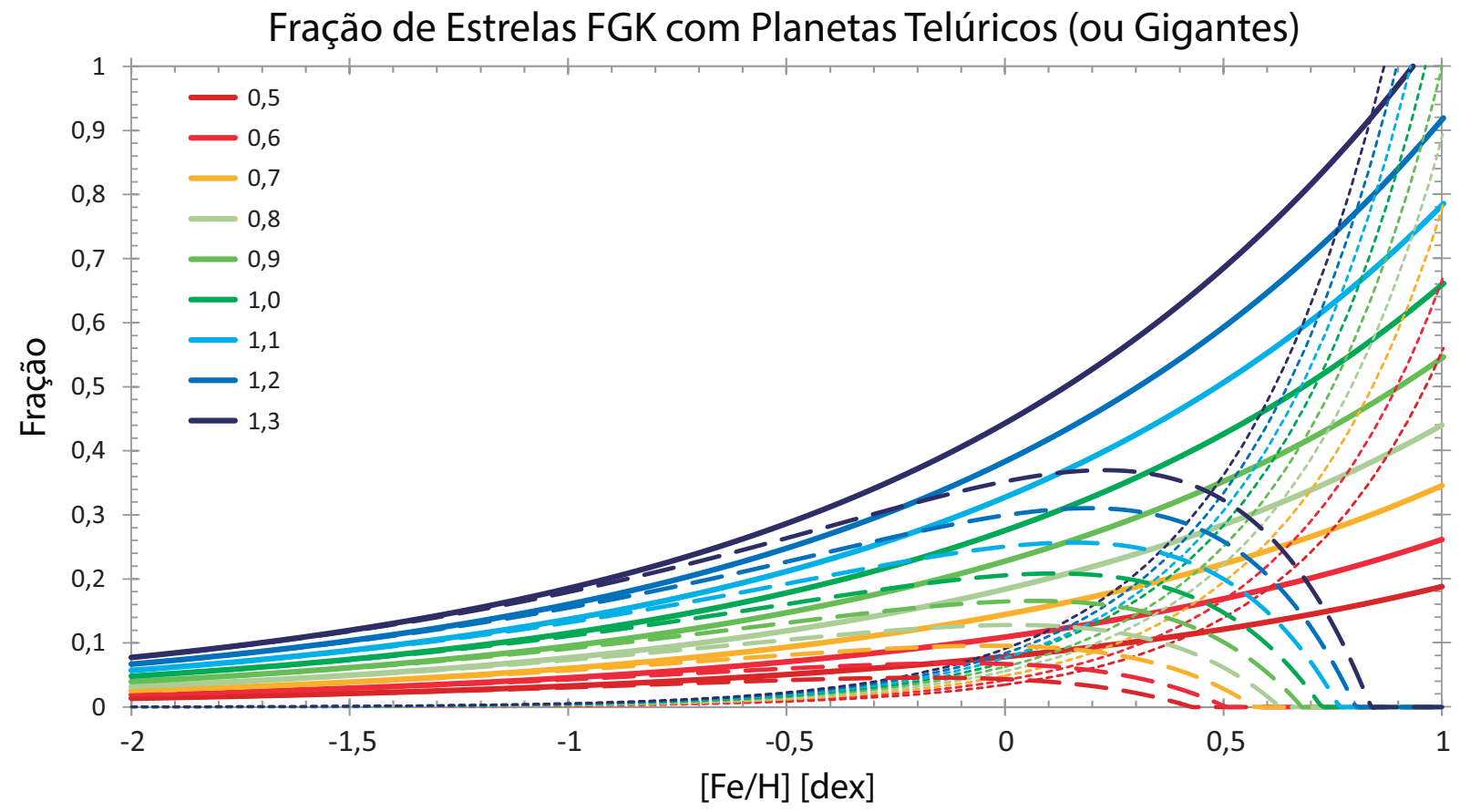

Figura 5.3: Fração das estrelas com planetas de certo tipo. Linhas cheias espessas são nosso ajuste usando dados de Wang e Fischer (2015) e Zhu et al. (2018). Linhas pontilhadas são o ajuste de Johnson et al. (2010) para planetas gigantes. Linhas tracejadas são a subtração das duas curvas. A legenda se refere à massa estelar em massas solares. 


\subsubsection{Planetas Gigantes e Habitabilidade}

Quando os fragmentos do cometa Shoemaker-Levy 9 colidiram com Júpiter em 1994, produzindo marcas escuras visíveis por meses, tivemos um vislumbre de que o Sistema Solar não era tão pacífico quanto achávamos e que planetas gigantes poderiam, de certa forma, aumentar a habitabilidade de planetas rochosos no mesmo sistema ao atrair ou desviar cometas e asteroides das partes mais externas dos sistemas, diminuindo a chance de impactos com os planetas rochosos (Wetherill, 1994). Considerando como a última grande extinção em massa em nosso planeta, a extinção do Cretáceo-Paleogeno (K-Pg), que atingiu fortemente os dinossauros dentre miríades de outras criaturas, pode ter sido causada pelo impacto de um asteroide (Alvarez et al., 1980), e vemos como um mecanismo para diminuir as chances de impactos seria benéfico para a biosfera. Pode ser que impactos de asteroides em escalas de milhões de anos sejam menos relevantes para a microfauna de bactérias e micro-organismos do que para a megafauna, mas planetas gigantes poderiam ser benéficos sob esse ponto de vista. Por outro lado, pode ser que planetas gigantes tenham papéis mais sinistros a representar com relação à habitabilidade.

Uma causa possível para o grande bombardeio pesado do Sistema Solar interior (Late Heavy Bombardment - LHB) 3,9 Ga atrás pode ter sido a migração planetária de Júpiter e Saturno, desestabilizando as órbitas dos objetos menores do Sistema Solar e aumentando a taxa de impactos (Gomes et al., 2005). Então, embora em longo prazo haja ganhos em sua presença, a possibilidade de migração e desestabilização de órbitas deixa incerto seu papel com relação à habitabilidade.

A existência dos chamados Júpiteres Quentes, planetas gigantes que orbitam bem próximos de suas estrelas, piora a situação dos planetas gigantes com relação à habitabilidade de planetas rochosos, já que planetas gigantes se formam distantes de suas estrelas e só poderiam chegar a órbitas tão próximas migrando para o interior do sistema (Lin et al., 1996). Isso poderia ser devastador para possíveis planetas, planetésimos e para o disco protoplanetário, ao redor da estrela, do qual os planetas acretam massa ao crescer. Lineweaver (2001); Lineweaver et al. (2004); Prantzos (2008) e Gowanlock et al. (2011) utilizaram a relação entre planetas gigantes e a metalicidade estelar supondo que sistemas com planetas gigantes (ou apenas Júpiteres quentes) seriam completamente inabitáveis, não teriam planetas rochosos ou os teriam fora dos critérios de habitabilidade, fora da ZHC, tendo 
pouca água, baixa massa, etc.

Não tivemos conhecimento de trabalhos que analisaram a presença (ou ausência) de planetas rochosos em sistemas com planetas gigantes dentre os sistemas de exoplanetas confirmados. Mas simulações de migrações planetárias e interações orbitais entre planetas indicam que planetas gigantes podem influenciar profundamente na estrutura e habitabilidade dos sistemas (Levison e Agnor, 2003). Migrações planetárias de planetas gigantes podem destruir parcialmente os discos protoplanetários, mas deixando para trás material suficiente para formar planetas rochosos (Fogg e Nelson, 2006), também misturando materiais de partes diferentes do disco, permitindo que planetas rochosos ricos em água sejam formados do material sobrevivente na ZHC (Mandell et al., 2007; Raymond et al., 2006, 2005). Mesmo sem grandes migrações, a excentricidade da órbita dos planetas gigantes e sua proximidade do sistema interior podem permitir (ou forçar) uma grande variedade de massas e conteúdos de água de planetas rochosos (Raymond et al., 2004). Mais especificamente, as simulações de Raymond (2006) indicam que em estrelas de 1,0 $\mathrm{M}_{\odot}$ planetas gigantes inibiriam a formação de planetas rochosos de mais de $0,3 \mathrm{M}_{\oplus}$ na $\mathrm{ZHC}$ se estivessem em órbitas menores do que 2,5 ua e inibiriam o aporte de água do sistema exterior para o sistema interior se estivessem em órbitas de menos de 3,5 ua.

Parece, então, que a formação e permanência de planetas rochosos é prejudicada, mas não completamente impedida em sistemas com planetas gigantes e mesmo em sistemas com Júpiteres quentes. No entanto, seriam planetas rochosos do tipo certo, seriam telúricos? Estamos interessados num estreito intervalo de massas e numa específica composição de rochas e metais. Voláteis demais podem atrapalhar.

Pensamos na Terra como um planeta rico em água, mas a água superficial em nosso planeta perfaz somente $0,02 \%$ da massa de nosso planeta. Parece haver espaço para dobrar essa fração sem que essa água cobrisse toda a superfície, mas quando a fração de água simplesmente chegasse aos porcentos o planeta poderia ser caracterizado como um planeta oceano, coberto completamente por uma capa d'água. Frações maiores até alterariam toda a química das rochas, a estrutura interna e a geofísica do planeta, talvez se assemelhando mais às grandes luas de Júpiter e Saturno, com baixa densidade (volte à Figura 3.3, da relação massa-raio, e compare a densidade das grandes luas com os planetas telúricos). Não sabemos se a tectônica de placas, o ciclo do carbono geológico ou sequer se o manto convectivo como o conhecemos seriam possíveis em tais condições. Não necessariamente o 
planeta seria completamente inabitável, mas estaria fora dos critérios mais tradicionais de habitabilidade e, mais importante para esse estudo, fora do escopo desse trabalho e fora da capacidade de simulação de nosso modelo de habitabilidade planetária.

Nós não sabemos o quanto uma maior taxa de impacto por asteroides e cometas afetaria a vida microbiana, mas a formação de um planeta pouco massivo ou super rico em voláteis poderia até inibir o surgimento da vida, e poderia nem mesmo haver planeta para sofrer impactos. Um planeta telúrico na ZHC de um sistema sem gigantes migrantes e distante dos gigantes atuais poderia aproveitar o efeito protetor dos planetas gigantes, mas são muitos passos até esse ponto, a maioria dos sistemas talvez não tivesse tanta sorte. Por conta disso, estamos mais inclinados a respaldar, em primeira aproximação, a ideia dos planetas gigantes como provocadores de inabitabilidade num sistema planetário. Modelamos isso subtraindo a fração de estrelas com planetas gigantes da fração de estrelas com planetas telúricos, obtendo uma função bem mais plana em metalicidade (o que é retratado na Figura 5.3). Vamos comentar dessa escolha a seguir, ao analisar a habitabilidade da ViaLáctea em grandes escalas.

\subsubsection{Planetas Telúricos na ZHC}

Estritamente, o que estimamos é a fração de estrelas FGK com pelo menos um planeta telúrico em função da metalicidade e da massa estelar, pode ser que haja mais de um planeta telúrico em cada sistema.

Isso foi apontado por Zhu et al. (2018) que, além de estimar a fração de $30 \%$ para estrelas do tipo solar com planetas rochosos a partir de dados do Kepler, também estimou que cada sistema planetário teria uma média de 3,0(3) planetas. Novamente, os planetas em sua amostra têm, em média, raios maiores do que os de nosso interesse e eles não consideram planetas de raios menores do que o terrestre, mas usaremos esse dado como um aproximador da realidade.

Queremos saber mais do que somente a fração de estrelas com planetas telúricos, queremos saber em quantas dessas estrelas esses planetas estão na ZHC. De todos os semieixos maiores que os planetas telúricos poderiam ter, qual fração desses cairia dentro da ZHC? Nós temos a largura da ZHC, então falta o tamanho dessa região de possíveis posições. Por simplicidade não vamos limitar o quão perto da estrela um planeta poderia orbitar. Isso nos parece aceitável se o limite exterior dessa região for bem maior do que o limite interior. 
Não necessariamente quer dizer que o planeta se formou ali, só que, após os períodos mais agitados de interação planetária e migrações, ele poderia residir nessa órbita.

Pensamos em vários jeitos de estimar o limite exterior. O primeiro é simplesmente usar o limite de período na amostra de Zhu et al. (2018), que é de 400 dias. No caso do Sistema Solar, daria pouco mais do que 1 ua. Isso pode ser uma subestimação por não incluir nem mesmo o limite externo da ZHC, quanto por não incluir Marte em 1,5 au. Algo pelo menos na órbita de Marte talvez funcionasse melhor como limite exterior.

Muito além de Marte teríamos o problema da interferência gravitacional de Júpiter, podendo impedir que planetas se formassem e, muito importante, além da linha de neve (snow line) é bem mais fácil acumular voláteis e planetas rochosos poderiam ter composições bem diferentes daquelas com as quais estamos trabalhando. No Sistema Solar na época de formação dos planetas, a linha de neve estava em 2,5 ua (Raymond et al., 2004; Abe et al., 2000). Como mencionado antes, esse valor de 2,5 ua também é o mínimo semieixo maior que um planeta gigante poderia ter antes de interferir consideravelmente na formação e aporte de água em planetas rochosos na ZHC de uma estrela como o Sol (Raymond, 2006). No caso específico do Sistema Solar, $\sim 2,5$ ua parece ser uma estimativa aceitável.

Em Raymond (2006) esse limite para as órbitas de planetas gigantes varia com algo como $M_{*}{ }^{4}$ no intervalo de massas estelares de nosso interesse. Por outro lado, a massa dos discos protoplanetários em simulações tem uma dependência na forma de lei de potência com a massa estelar (Ida e Lin, 2005). Em Alibert et al. (2011) é dada como $M_{*}^{1,2}$. E em Mulders et al. (2015) a linha de neve varia com $M_{*}^{1,14}$. Como estamos supondo que a existência de planetas gigantes vai sempre inibir a existência dos planetas telúricos, não importando outros fatores, parece fazer mais sentido delimitar e escalonar o limite externo da região onde os planetas telúricos poderiam existir usando a linha de neve e a massa dos discos protoplanetários que influenciam na composição dos planetas mesmo sem os planetas gigantes. Então parece aceitável supor a largura da região ao redor de uma estrela em que os planetas de nosso interesse podem existir, $R_{P T}$, como:

$$
R_{P T}=2,5 \text { ua } \times M_{*}^{1,2}
$$

Simplesmente dividir a equação 5.2, da largura da ZHC, pela equação 5.3 dá a chance 
de um planeta de nosso interesse estar na ZHC supondo que a distribuição de semieixos maiores seja uniformemente destruída na distância, ou seja, que os planetas não se acumulem mais ou menos em distâncias específicas. No Sistema Solar, as distâncias dos planetas seguem a Lei de Titius-Bode, com espaçamentos cada vez maiores entre planetas cada vez mais distantes, haveria então uma maior densidade de planetas em distância menores, mais perto de suas estrelas. No entanto, a análise de Weiss et al. (2018) de sistemas múltiplos do Kepler indica que, dentre outras coisas, planetas de um sistema tendem a ter um espaçamento regular.

Como a formação de planetas depende da metalicidade e esta varia nos discos protoplanetários com a distância à estrela (Johnson e Li, 2012), talvez houvesse mais chances de planetas rochosos se formarem mais perto da estrela, onde o disco seria mais metálico, do que longe dela. Não necessariamente a configuração final dos sistemas será a de formação, já que muitas interações entre os planetas podem mudar as órbitas. A relação de distância de Weiss et al. (2018) seria então de sistemas mais velhos e, talvez, mais estáveis. Esse resultado é mais de nosso interesse, já que queremos analisar a ZHC em longas escalas de tempo. Então vamos manter nossa suposição de distribuição de semieixos maiores uniformemente distribuída na distância.

Um último ponto é que estrelas costumam fazer parte de sistemas duplos, triplos ou múltiplos. Sistemas múltiplos classicamente não são bem vistos como habitáveis na literatura (Huang, 1959, 1960; Hohlfeld e Terzian, 1977). As potenciais variabilidades do fluxo resultante das múltiplas estrelas e a instabilidade das órbitas em longo prazo impossibilitariam a habitabilidade por longos períodos de tempo. Um sistema bem compacto (com o planeta orbitando o centro de massa do sistema) ou bem afastado (com o planeta orbitando próximo de apenas uma das estrelas) poderia mitigar esses efeitos, mas é difícil calcular as órbitas, o tempo que os planetas passariam na ZHC e a ZHC em si (Holman e Wiegert, 1999; Kane e Hinkel, 2012).

Trabalhos mais recentes constroem uma visão menos catastrófica da habitabilidade de sistemas múltiplos, indicando-os como alvos plausíveis na busca por planetas habitáveis (Eggl et al., 2012; Bromley e Kenyon, 2015; O’Malley-James et al., 2012; Haghighipour e Raymond, 2007). Eles seriam piores candidatos do que estrelas solitárias, com mais condições orbitais a serem cumpridas para a habitabilidade dos planetas (Kaltenegger e Haghighipour, 2013) e grande dependência da habitabilidade com a excentricidade do 
sistema (Eggl et al., 2012), mas talvez metade dos sistemas sejam compactos ou afastados o suficiente a ponto de permitirem planetas telúricos na ZHC (Whitmire et al., 1998; Haghighipour, 2010).

Infelizmente, nosso modelo de habitabilidade planetária não pode ser facilmente alterado no momento para averiguar a habitabilidade de planetas em sistema múltiplos. Teremos de excluí-los de nossa análise. Segundo Duchêne e Kraus (2013), a fração das estrelas em sistemas múltiplos aumenta com a massa estelar, de algo como $26 \%$ em estrelas M até mais de 80\% em estrelas O. Aproximadamente 44\% das estrelas FGK fariam parte de um sistema múltiplo (Raghavan et al., 2010; Duchêne e Kraus, 2013). Dessa forma, restringimo-nos à fração $f_{E S}$ de 0,56 de estrelas FGK solitárias em nosso estudo.

Para uma estrela de 1,0 $\mathrm{M}_{\odot}$ e 4,57 Ga e usando a largura ponderada da ZHC, temos: 0,14 ua / 2,5 ua $\approx 0,058$. Somente $6 \%$ de chance de um planeta telúrico estar na ZHC. Se as órbitas não se distribuírem uniformemente e houver maior chance de órbitas menores, é bem provável dessa porcentagem cair, já que a chance de órbitas na região da ZHC também cairia. Usando a equação 5.2 menos a equação 5.1 para a mesma massa estelar e para a metalicidade solar $([\mathrm{Fe} / \mathrm{H}]=0,0$ dex $)$ nós temos que a fração de estrelas FGK com planetas telúricos é: $f_{t e l}-f_{\text {gig }} \approx 0,276$ - 0,07 =0,206. Somente $56 \%$ seriam estrelas solitárias, então multiplicamos por 0,56 e temos: $0,56 \times 0,206=0,115$. Multiplicando esses dois números e o resultado multiplicamos por três (porque haveria três planetas em média por sistema e isso triplica as chances de haver ao menos um deles na ZHC) para termos: $0,058 \times 0,115$ $\times 3 \approx 0,020$. Então somente $2 \%$ das estrelas individuais de massa e metalicidade solar teriam um planeta telúrico na ZHC na Via-Láctea atual. Essa é uma porcentagem bem baixa, mas estamos usando a ZHC que nós derivamos anteriormente e sabemos que ela é mais estreita do que a maioria das outras ZHC da literatura.

\subsection{Modelo de Evolução Química da Galáxia}

Sabendo da relação entre metalicidade e massa estelar com a frequência de planetas ao redor de estrelas, precisamos saber da distribuição de metalicidade e de massas estelares na Galáxia. A metalicidade atual da Via-Láctea pode ser medida, e algumas estimativas quanto à sua evolução podem ser feitas. Mas é preciso usar modelos para acessar a distribuição mais precisamente ao longo da história da Galáxia. 
Nós utilizamos o modelo de evolução química (MEQ) (Matteucci e François, 1989; Chiappini e Gratton, 1997; Lanfranchi e Friaça, 2003) de duplo infall para a formação do disco da Galáxia supondo simetria angular e sem escoamento de matéria. A taxa de infall é exponencialmente decrescente no tempo e o tempo de formação do disco fino depende da distância Galactocêntrica, com regiões em raios menores se formando mais rapidamente. O modelo segue a abundância de $\mathrm{He}, \mathrm{C}, \mathrm{N}, \mathrm{O}, \mathrm{Mg}, \mathrm{Si}, \mathrm{S}$ e Fe das gerações de estrelas e do gás, mas, por não ser relevante para seu propósito inicial, por enquanto não segue a abundância de isótopos radioativos, então não poderemos avaliar nesse momento um possível gradiente de radioativos em escala Galáctica que influenciaria na constituição de planetas telúricos e em sua habitabilidade.

O modelo não leva em consideração a cinemática e as características "topográficas" da Galáxia, como os braços espirais ou a barra. Isso não é incomum em outros modelos focados na distribuição química usado no estudo da habitabilidade Galáctica (Lineweaver et al., 2004; Prantzos, 2008; Gowanlock et al., 2011). Um panorama de alguns resultados do modelo comparado a valores para a Galáxia é apresentado na Tabela 5.1, a metalicidade média do gás e das estrelas e a SFR são dadas na Figura 5.4, e o gradiente radial atual de metalicidade do modelo é dado na Figura 5.5.

Tabela 5.1 - Comparação de resultados do modelo de evolução química com dados da literatura. A vizinhança solar foi tomada como um disco de raio de $3 \mathrm{kpc}$ em torno do Sol, situado no raio Galactocêntrico de 8 kpc. "Taxa de SN" é a soma de todos os tipos de supernovas: Ia, Ib e II segundo a referência citada.

\begin{tabular}{|c|c|c|c|c|}
\hline Local & Descrição & Valor & \multicolumn{2}{|c|}{ Valor de referência } \\
\hline \multirow{4}{*}{ No disco } & Taxa de supernovas Ia & 0,30 século $^{-1}$ & $\sim 0,36$ século $^{-1}$ & van den Bergh (1990) \\
\hline & Taxa de supernovas II & 0,90 século $^{-1}$ & $\sim 1,3$ século $^{-1}$ & van den Bergh (1990) \\
\hline & Taxa de supernovas & 1,20 século $^{-1}$ & $\sim 2$ século $^{-1}$ & van den Bergh (1990) \\
\hline & Taxa de SN / Taxa de SN Ia & 3,02 & $3-4$ & Li et al. (2011) \\
\hline $\mathrm{Na}$ vizinhança solar & Taxa de supernovas II & 0,06 século $^{-1}$ & $0,03-0,07$ século $^{-1}$ & van den Bergh (1990) \\
\hline \multirow[t]{2}{*}{ No raio solar } & Taxa de supernovas Ia & $2,93 \mathrm{M}_{\odot} \mathrm{Ga}^{-1} \mathrm{pc}^{-2}$ & $3-10 \mathrm{M}_{\odot} \mathrm{Ga}^{-1} \mathrm{pc}^{-2}$ & $\begin{array}{c}\text { Miller e Scalo (1979) } \\
\text { Güsten e Mezger (1982) }\end{array}$ \\
\hline & Densidade do gás & $12 \mathrm{M}_{\odot} \mathrm{pc}^{-2}$ & $\sim 10 \mathrm{M}_{\odot} \mathrm{pc}^{-2}$ & Lacey e Fall (1985) \\
\hline
\end{tabular}

A metalicidade das estrelas depende da metalicidade do gás das nebulosas das quais elas se formaram e esse gás é enriquecido pelas gerações anteriores de estrelas. Supõe-se 
no modelo que todas as estrelas terminam como supernovas ou nebulosas planetárias e que há ejeção de energia, massa e metais instantaneamente no meio interestelar com a morte das estrelas. No MEQ, o tempo de vida das estrelas na sequência principal é dado pela equação de Renzini e Buzzoni (1986):

$$
\log M_{*}=0,0558 \times \log ^{2} \tau_{S P}-1,338 \times \log \tau_{S P}+7,764
$$

com $M_{*}$ dado em massas solares e $\tau_{S P}$ em anos. Essa equação é diferente da equação 4.1 usada no capítulo anterior, no entanto, por consistência, usamos a equação 5.4. Ela fornece idades máximas menores do que seria esperado para estrelas de mais alta massa em nosso intervalo de massas de interesse, mas essas estrelas são menos frequentes, então será uma diferença pequena.

\section{Resultados do MEQ}
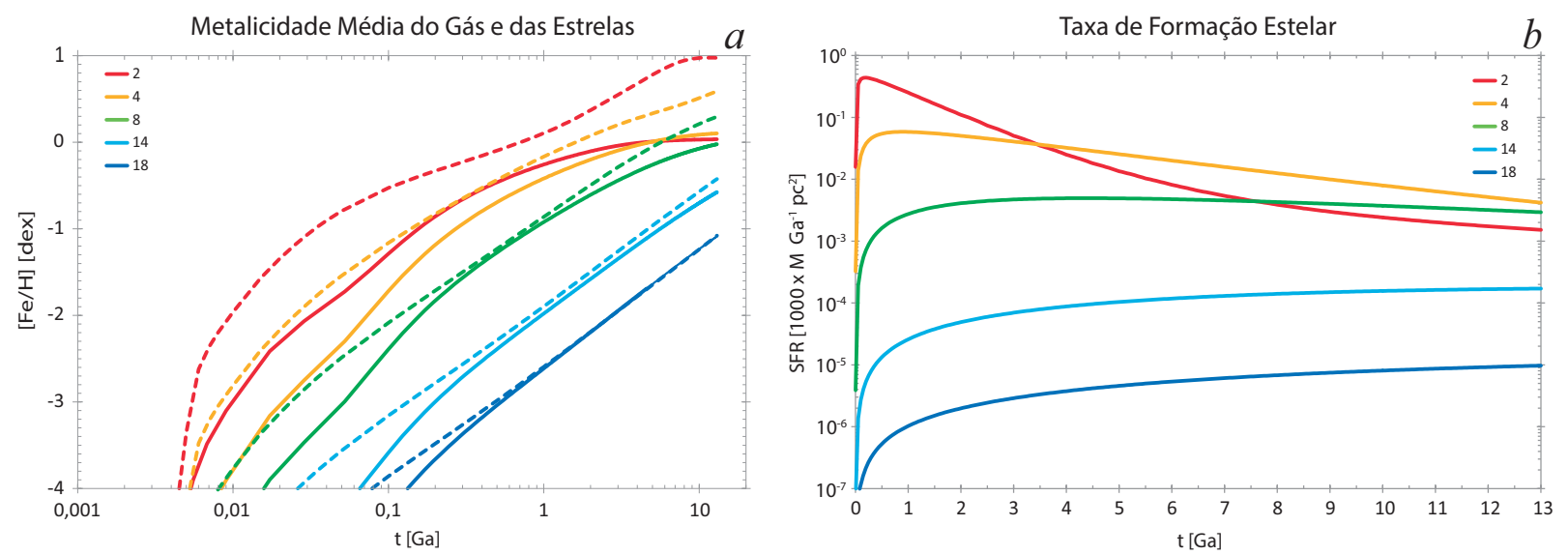

Figura 5.4: Alguns resultados do modelo de evolução química do disco da Galáxia. a) metalicidade média do gás (linhas tracejadas) e das estrelas (linhas cheias) para raios selecionados. b) taxa de formação estelar para alguns raios selecionados. A legenda é relativa ao raio Galactocêntrico em kpc.

A quantidade de massa de gás transformada em estrelas numa geração depende da taxa de formação estelar (star formation rate - SFR) naquele momento, e a distribuição do número de estrelas de certa massa formada é dada pela função de massa inicial (initial massa function - IMF) de Salpeter (Salpeter, 1955) entre 0,1 e $100 \mathrm{M}_{\odot}$ :

$$
\phi(m)=A \times M_{*}^{-(1+x)},
$$

onde $A$ é uma constante normalizadora, e $x=1,35$. 
Outras IMFs mais recentes, como Kroupa (Kroupa, 2001), têm uma distribuição mais plana em baixas massas, fazendo a IMF de Salpeter superestimar o número de estrelas de baixa massa. Isso vai influenciar no número total de estrelas no modelo, já que parte da massa que formaria estrelas de média e alta massa acabaria em estrelas de baixa massa, e sendo de baixa massa, é possível fazer bem mais delas. As estrelas FGK, de nosso interesse, acabariam um pouco subestimadas em número, o que implicaria em estimativas conservadoras para o número de planetas telúricos habitáveis, mas isso não influenciaria muito nos valores comparados, pois a diferença entre IMFs é maior para massas estelares abaixo de $\sim 0,5 \mathrm{M}_{\odot}$, já fora do intervalo de massas de nosso interesse. Dessa forma, por usarmos a mesma IMF em todos os raios e épocas, a diferença entre as densidades de planetas habitáveis por unidade de área do disco da Galáxia ainda seria confiável.

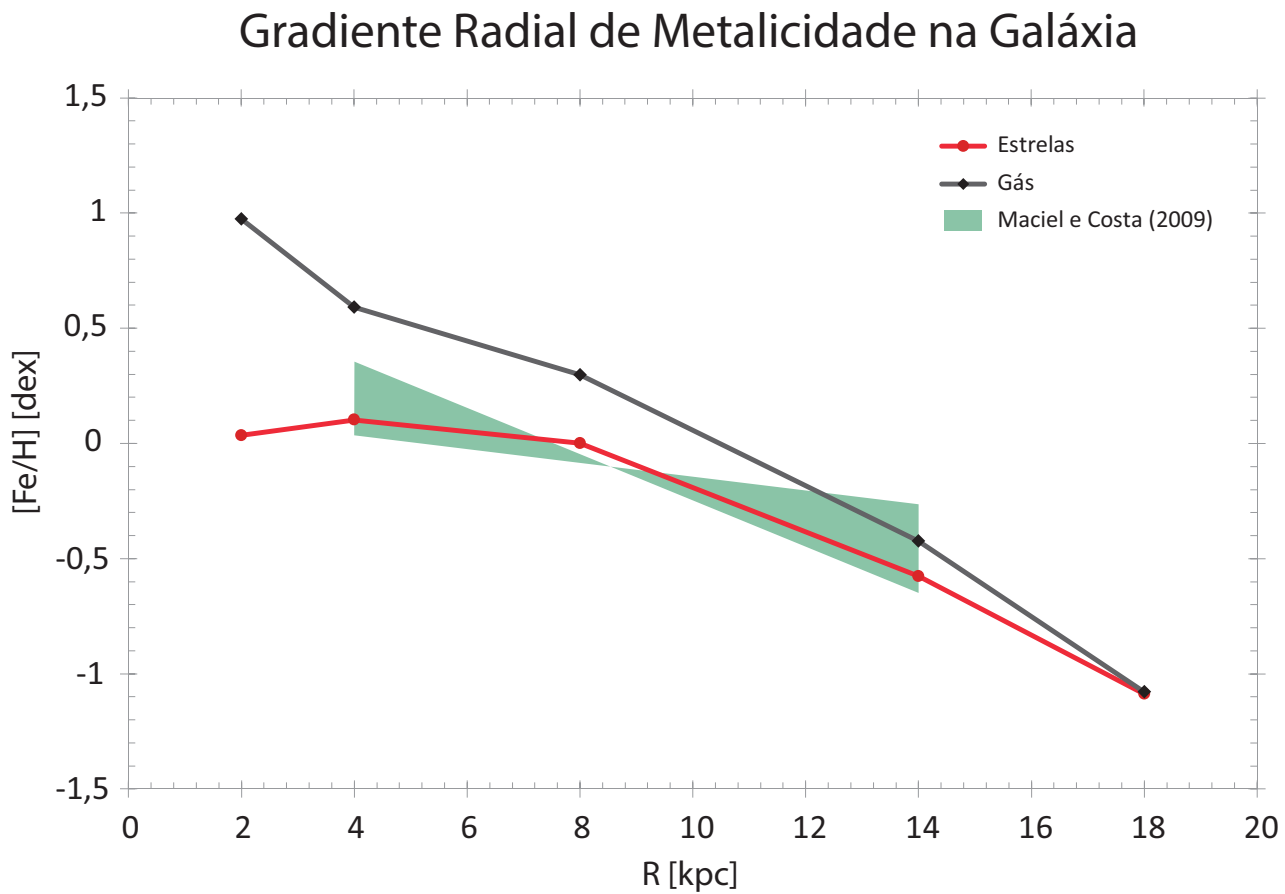

Figura 5.5: Comparação do gradiente radial de metalicidade na Via-Láctea em nosso modelo com a literatura. O coeficiente linear do intervalo de gradientes de metalicidade de Maciel e Costa (2009) foi obtido fazendo as curvas passarem pela metalicidade média da vizinhança solar segundo Rocha-Pinto e Maciel $(1996),[\mathrm{Fe} / \mathrm{H}] \approx-0,1$ dex no raio Galactocêntrico de 8,5 $\mathrm{kpc}$.

\subsection{Cálculo da Densidade de Planetas Habitáveis}

Tendo a função que dá a fração de planetas telúricos na ZHC de estrelas FGK em função da metalicidade, massa estelar e idade e o MEQ podemos estimar a densidade de 
planetas habitáveis na Galáxia, mas será mais complicado do que a estimativa que fizemos para uma estrela de $1,0 \mathrm{M}_{\odot}, 4,57 \mathrm{Ga}$ e $[\mathrm{Fe} / \mathrm{H}]=0,0$ dex. Usar valores médios de massa estelar, idade e metalicidade, funciona, mas é impreciso e perdemos o que o MEQ nos dá a respeito de conhecer o estado de várias variáveis na Galáxia ao longo do tempo e do raio Galactocêntrico.

Num determinado tempo $t$ (idade da Galáxia) e raio Galactocêntrico $R$, o MEQ nos fornece a $S F R$ e a metalicidade das estrelas e do gás ali. Usamos isso para caracterizar a geração de estrelas que nasceram naquele raio num $\Delta t$ ao redor daquele momento $t$. Também podemos saber o número de estrelas por unidade de área que nasceram em $t$ e $R$ e seguir essa geração no tempo para desconsiderar as estrelas de mais alta massa conforme essas forem saindo da sequência principal. Nós sabemos quantas estrelas se formaram em $t$ e $R$ usando a taxa de nascimento estelar em $t$ e $R$ (Matteucci, 2003), dada pela multiplicação da $S F R$ (em massas solares por unidade de tempo e área) pela IMF normalizada de 0,1 até $100 \mathrm{M}_{\odot}$ e integramos no intervalo de massas de nosso interesse, de 0,5 $\mathrm{M}_{\odot}$ até, no máximo, 1,3 $\mathrm{M}_{\odot}$. No máximo, porque o limite superior pode ser menor com as estrelas mais massivas saindo da sequência principal, seria então só até uma massa $\mathrm{M}_{\tau_{S P}}$. Essa integral nos dá quantas estrelas daquela geração e do intervalo de massas de interesse que existem ao longo do tempo. De maneira mais compacta:

$$
\int_{0,5}^{M_{\tau_{S P}}} I M F \times S F R \times \Delta t d M_{*} .
$$

A $S F R$ e o $\Delta t$ não dependem da massa estelar e podem ser postos para fora da integral, mas a $I M F$ depende e é a função que acabamos inegrando. A IMF é uma função dada por uma lei de potência que é facilmente integrável. O resultado depende de $\mathrm{M}_{\tau_{S P}}$, que por sua vez depende de $t_{*}$, e que vamos avaliando o valor conforme aquela geração envelhece. A cada passo em $t$ do modelo, temos uma nova geração estelar que devemos somar com as anteriores para caracterizar aquele momento e raio da Galáxia, já que as estrelas das gerações anteriores ainda estão ali, ou ao menos as menos massivas. Isso nos dá as informações acerca das estrelas, mas falta a parte com relação aos planetas telúricos habitáveis.

Essa parte, $f_{P T Z H C}$, é a conta que fizemos anteriormente para o caso específico do Sol: a função de fração de planetas telúricos por estrela, $f_{\text {tel }}$, menos a função da fração 
de planetas gigantes por estrela, $f_{g i g}$, tudo isso multiplicado pela função de largura da ZHC, $\triangle Z H C$, dividida pela função de tamanho da região com planetas telúricos de nosso interesse ao redor das estrelas, $R_{P T}$, vezes a fração dessas estrelas que são solitárias, $f_{E S}$, vezes o número médio de planetas por sistema, $N_{P S}$. Ou de maneira mais compacta:

$$
f_{P T Z H C}=N_{P S} \times f_{E S} \times\left(f_{t e l}-f_{g i g}\right) \times \frac{\Delta Z H C}{R_{P T}} .
$$

O fator $f_{P T Z H C}$ depende da massa, metalicidade e idade estelares. Para a integral na massa (equação 5.6), só a dependência na massa é relevante. A dependência com a metalicidade mantivemos constante naquela geração, por importar apenas a metalicidade em que aquelas estrelas (e planetas) se formaram. A dependência no tempo nós seguimos e avaliamos $f_{P T Z H C}$ como avaliamos $\mathrm{M}_{\tau_{S P}}$ ao longo do tempo. Juntando tudo temos:

$$
\int_{0,5}^{M_{\tau_{S P}}} f_{P T Z H C} \times I M F \times S F R \times \Delta t d M_{*} .
$$

Lembrando-se das formas de todas essas funções, a parte dependente da massa estelar é sempre uma lei de potência, então facilmente integrável. Tomando cuidado com as muitas constantes e com os termos dependentes da metalicidade e idade estelares, facilmente calculamos a integral. Ela dá a densidade (número por parsec quadrado) de planetas telúricos na ZHC de estrelas FGK ainda sobreviventes em $t_{*}$ da geração de estrelas que se formaram com a metalicidade $[\mathrm{Fe} / \mathrm{H}]$ em $t$ e $R$. O resultado depende de $t_{*}$, que vamos reiterando a cada passo do modelo e somando independentemente com as outras gerações para ter o número total de planetas do nosso interesse em $t$ e $R$. Um lembrete é que $t_{*}$ é a idade das estrelas (e planetas) de uma geração específica, e $t$ é a idade da Galáxia.

Antes de seguirmos para os resultados, vamos fazer um cálculo simples do número de planetas telúricos habitáveis de nosso interesse na Galáxia hoje $\left(N_{P H}\right)$ ao espírito da equação de Drake. Começamos estimando o número de estrelas na Galáxia em 250 bilhões (um meio caminho entre os 100 e 400 bilhões normalmente mencionados). Precisamos selecionar apenas as estrelas de tipo FGK. Estimamos essa fração em 10\%. Algo como $60 \%$ dessas estrelas são solitárias e algo como apenas 30\% dessas estrelas têm um planeta telúrico. Somente 1\% desses planetas estariam na ZHC e multiplicamos por 3, por ser a média de planetas por sistema. Isso fornece: 


$$
N_{P H}=250 \times 10^{9} \times 0,1 \times 0,6 \times 0,3 \times 0,01 \times 3 \approx 135 \times 10^{6} .
$$

Então algo como uma centena de milhões de planetas habitáveis na Via-Láctea hoje.

\subsection{As Regiões Mais Habitáveis na Galáxia}

\subsubsection{Raios e Tempos}

"Habitável" aqui deve ser entendido como com maior número ou densidade de planetas habitáveis em comparação com outras regiões da Galáxia. A soma das integrais da equação 5.8 de cada geração dá a densidade de planetas telúricos na ZHC, $\sigma_{P T Z H C}$, em unidades de planetas por parsec quadrado do disco da Galáxia. Acompanhando esse valor para alguns raios específicos temos a Figura 5.6a. Claramente há um gradiente na densidade de planetas, com o raio de $2 \mathrm{kpc}^{1}$ sempre com maior densidade. Os dois raios mais internos têm valores em queda na segunda metade de vida da Galáxia. Isso se dá porque, conforme o tempo passa, a ZHC vai se estreitando e mais estrelas de cada vez mais gerações saem da sequência principal, fazendo cada vez mais planetas serem perdidos. Com a taxa de formação estelar em queda, esses planetas não são suficientemente substituídos por planetas novos para manter a densidade constante. Em adição a isso, a estrelas formadas mais recentemente são as mais metálicas, talvez tão metálicas a ponto de produzirem menos planetas telúricos pela maior incidência de planetas gigantes nessas metalicidades. Em raios maiores a formação estelar ainda está alta o suficiente para manter a densidade constante ou sustentar um sutil aumento na densidade. Além disso, a metalicidade é menor nesses raios, o que provoca menor formação planetária, mas também menor formação de planetas gigantes.

No painel $b$ da mesma figura, temos o gradiente radial em vários momentos diferentes. Vemos o rápido aumento inicial na densidade nos raios internos e a sua lenta queda em tempos mais recentes. O raio de $2 \mathrm{kpc}$ tem hoje uma densidade de planetas telúricos habitáveis 10,5 vezes maior do que nosso raio de $8 \mathrm{kpc}$.

\footnotetext{
${ }^{1}$ Kilo parsec.
} 


\section{Densidade de Planetas Habitáveis na Galáxia}

Raios por Tempo

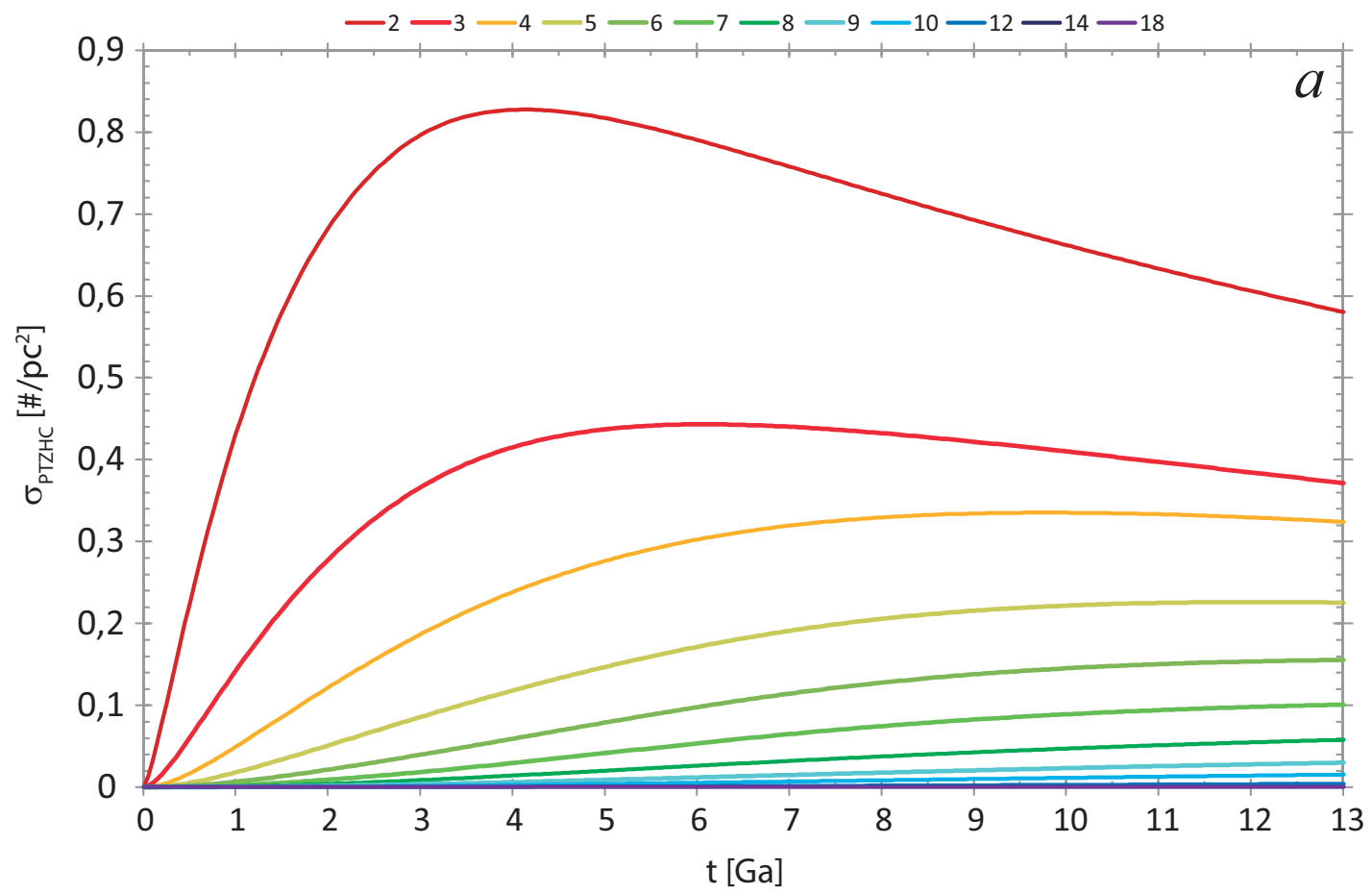

Idades por Raio

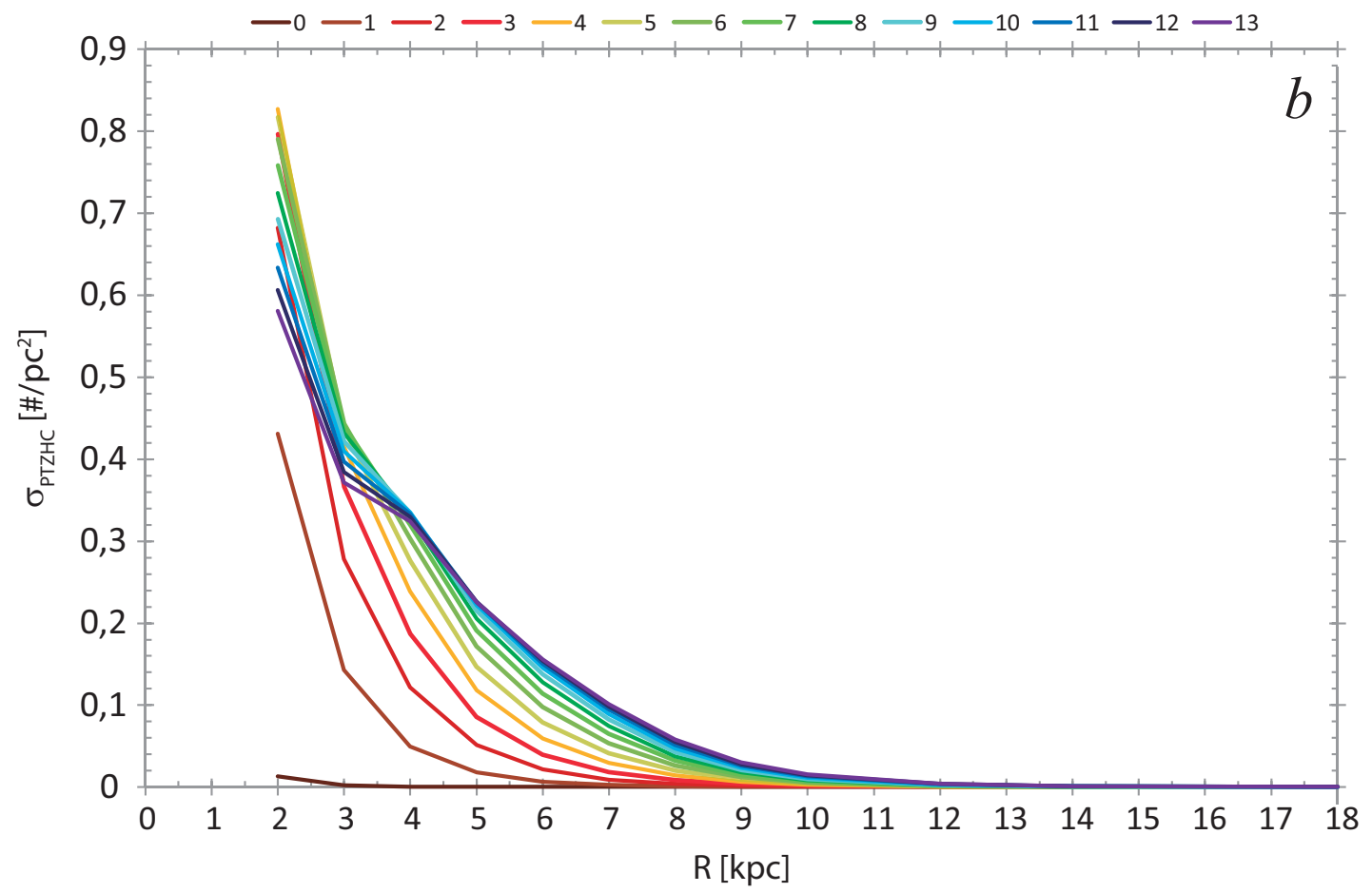

Figura 5.6: Densidade de planetas telúricos na ZHC de estrelas FGK que não fazem parte de sistemas múltiplos. a) alguns raios específicos são escolhidos e acompanhados ao longo do tempo. A legenda se refere aos raios em kpc. b) o perfil radial em tempos específicos. A legenda se refere aos tempos em Ganos. 
Nossos resultados de que o interior Galáctico, em especial o raio de 2 kpc, seria a região com maior densidade de planetas habitáveis está em acordo com trabalhos que indicam a Galáxia interior de 1 a 2 kpc (Prantzos, 2008) ou em 2,5 kpc (Gowanlock et al., 2011; Morrison e Gowanlock, 2015) como os raios mais habitáveis, mas está em desacordo com as estimativas iniciais de que a região mais habitável da Galáxia seria um anel localizado próximo do raio Galactocêntrico solar ${ }^{2}$ (Gonzalez et al., 2001) ou em aproximadamente de 7 a 8 kpc (Lineweaver et al., 2004). Pode ser que parte dessa diferença seja que a função da fração de estrelas com planetas habitáveis esteja sendo modelada com menor dependência da metalicidade e a inclusão da densidade de estrelas nos cálculos. Também não consideramos o efeito de supernovas, o que aqueles trabalhos fizeram, e a taxa de supernovas é um pouco maior no interior Galáctico.

\subsubsection{Números}

A Figura 5.7 combina a taxa de formação de planetas habitáveis na Galáxia com o número total de planetas habitáveis. Vemos como o pico na taxa de formação de planetas ocorreu durante os dois primeiros bilhões de anos da Galáxia, seguindo a taxa de formação estelar, e como tem caído fortemente desde então. O número total de planetas habitáveis cresce rapidamente seguindo a taxa de formação de planetas, mas se estabiliza próximo à época de formação do Sistema Solar. Algo como 60 milhões de planetas habitáveis ( 25\% do total) foram perdidos por estreitamento da ZHC e pela saída de estrelas da sequência principal.

Desconsiderar os planetas gigantes (zerar o termo $f_{\text {gig }}$ na equação 5.7) aumenta o número de planetas habitáveis hoje em $\sim 25 \%$ e impede a queda nas curvas de densidade para os raios interiores, mas não muda nenhum resultado qualitativo quanto às regiões interiores serem as de maior densidade de planetas habitáveis.

Com $1,9 \times 10^{8}$ de planetas habitáveis na Galáxia atual, nossa estimativa do fim da seção anterior de $10^{8}$ parece ter acertado na escala de grandeza. Esses números são superiores aos 4, $8 \times 10^{7}$ estimado por Franck et al. (2001) e inferiores aos 4, $55 \times 10^{10}$ de Guo et al. (2009). Simplesmente dividindo nossa estimativa pelo número de estrelas em nosso modelo nos dá que apenas 0,04\% das estrelas de nossa Galáxia teriam planetas habitáveis. Essa fração é problemática por podermos ter mais de um planeta habitável por sistema em

\footnotetext{
${ }^{2}$ A distância do Sol ao centro da Via-Láctea, aproximadamente 8-8,5 kpc.
} 
nosso modelo, então acabamos superestimando a fração real. Mesmo assim, essa fração é menor do que os $\sim 0,2 \%$ de Bounama et al. (2007) ou os incríveis $\sim 10 \%$ de todas as estrelas formadas na Galáxia de Lineweaver et al. (2004).

Parte dessa diferença pode estar no número total (e tipo) de estrelas de cada modelo de Galáxia utilizado em cada trabalho. No caso específico de Lineweaver et al. (2004), sua função de fração de estrelas com planetas habitáveis (Lineweaver, 2001) é consideravelmente diferente da nossa. Eles consideram a distribuição em função da metalicidade estelar a partir de dados somente de estrelas G e apenas subtraindo Júpiteres quentes, utilizando essa resultado como se fosse para planetas terrestres (todos eles seriam "Terras"), alcançando um pico de $\sim 60 \%$ das estrelas (do tipo solar?) de $[\mathrm{Fe} / \mathrm{H}] \sim 0,0$ dex com um planeta terrestre em. Essa fração é muito mais alta do que a nossa de 10\% para a fração de estrelas FGK de $[\mathrm{Fe} / \mathrm{H}] \sim 0,0$ dex com, ao menos, um planeta telúrico. A diferença aumenta se considerarmos que ainda tentamos estimar quantos desses planetas estariam de fato na ZHC, escluímos os sistemas múltiplos e ponderamos os resultados por massa estelar e planetária.

Os raios internos são os de maior densidade de planetas habitáveis, mas isso poderia ser menos relevante se o número total de planetas habitáveis fosse pequeno lá, já que a área interior do disco da Galáxia $(\sim 2-6 \mathrm{kpc})$ é bem menor do que o resto da área do disco ( 6-18 kpc). Estudamos isso computando o número de planetas habitáveis em anéis concêntricos do disco. A Figura 5.8 reúne os resultados. O anel de 7-9 kpc, próximo do raio solar, corresponde a apenas $10 \%$ da área do disco, mas possui $\sim 21 \%$ do número total de planetas habitáveis. A pequena região interna de $2-4 \mathrm{kpc}$, com $\sim 4 \%$ da área do disco concentra 23\% dos planetas habitáveis. O exterior Galáctico, de 9-18 kpc, 76\% da área do disco, possui apenas $\sim 14 \%$ dos planetas habitáveis. No entanto, é o anel de $4-7 \mathrm{kpc}$, com $\sim 10 \%$ da área, que concentra a maioria dos planetas habitáveis com $\sim 42 \%$ deles. O que acontece é que a área maior do anel de 4-7 kpc compensa sua menor densidade de planetas habitáveis em comparação ao anel de $2-4 \mathrm{kpc}$. Mesmo assim, a região de $2-7 \mathrm{kpc}$ concentra quase $2 / 3$ dos planetas habitáveis no disco inteiro. De maneira geral, as regiões internas do disco da Galáxia são as que oferecem as maiores chances de encontrar planetas habitáveis.

Nosso número de planetas habitáveis se manteve constante nos últimos bilhões de anos apesar da queda na densidade dos raios mais internos, porque integramos a densidade 


\section{Planetas Telúricos Habitáveis na Galáxia}

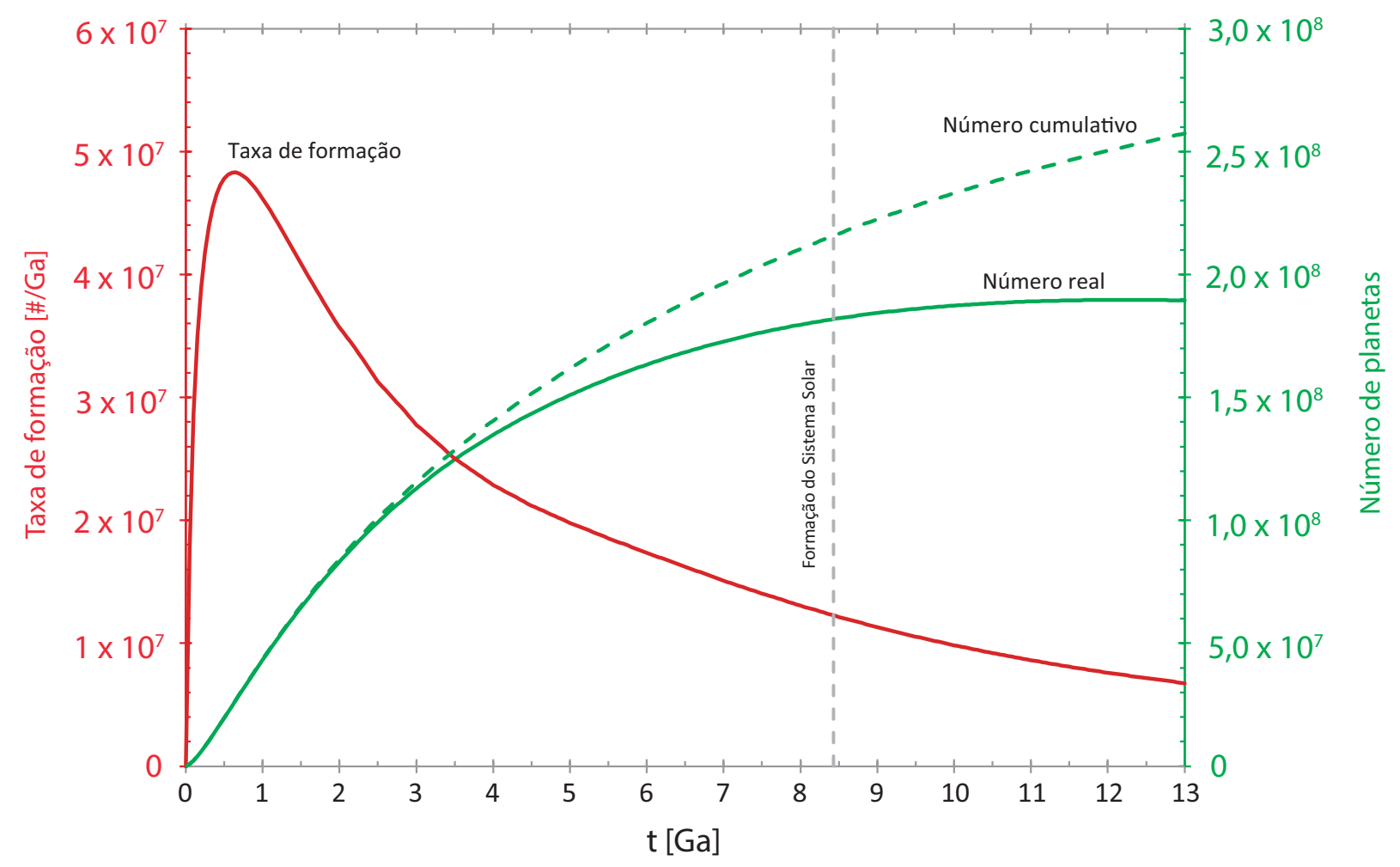

Figura 5.7: Taxa de formação (linha vermelha), número de planetas (linha verde cheia) e número cumulativo (linha tracejada verde) de planetas telúricos na ZHC de estrelas FGK que não fazem parte de sistemas múltiplos. A formação do Sistema Solar é marcada pela linha vertical tracejada cinza.

pela área do disco da Galáxia e a área referente aos raios mais internos é bem menor do que a área do resto do disco inteiro, onde a densidade é bem menor, mas está em ligeira ascensão. Uma coisa acaba compensando a outra. Considerando a queda na taxa de formação estelar devemos esperar que dificilmente o número de planetas habitáveis aumente além do patamar atual e que a habitabilidade da Galáxia como um todo entre em decadência. No entanto, as colisões da Via-Láctea com a Grande Nuvem de Magalhães em 2,4 Ga (Cautun et al., 2018) e com a Galáxia de Andrômeda em 4,5 Ga (van der Marel et al., 2019) podem acabar promovendo a formação estelar e aumentar o número de planetas habitáveis. 


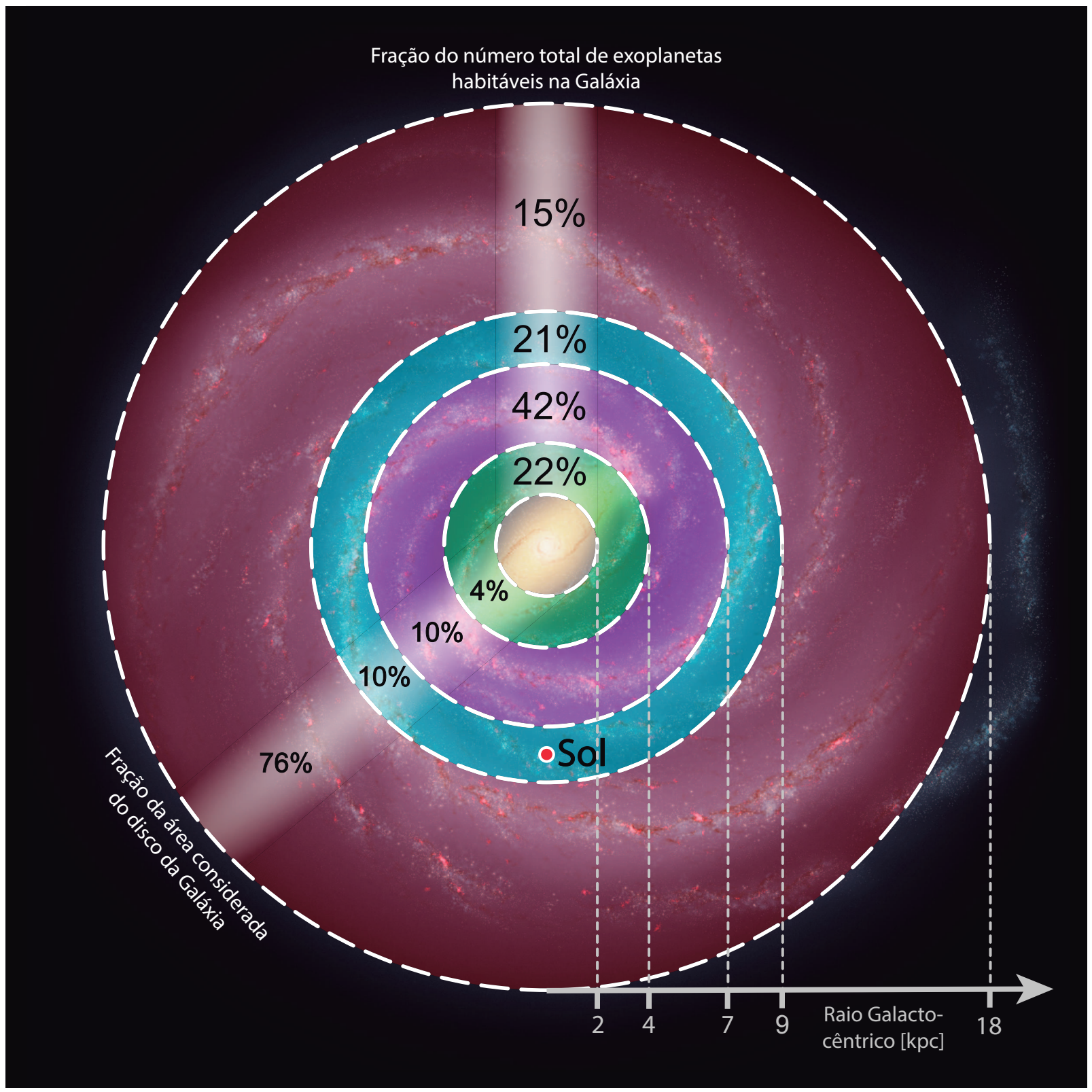

Figura 5.8: Fração do total de planetas habitáveis em anéis do disco da Galáxia. Ilustração da Via-Láctea de NASA/JPL-Caltech/R. Hurt (SSC/Caltech).

\subsubsection{Idades}

Na Figura $5.9 a$ temos a distribuição de idade dos planetas habitáveis hoje para todo o disco da Galáxia para o caso inicial, sem perder planetas por estreitamento da ZHC e pelas estrelas saírem da sequência principal (linha tracejada vermelha), caso com perda de planetas pelas estrelas saírem da sequência principal (linha tracejada azul), e o caso final, completo, com perda de planetas por estreitamento da ZHC e pelas estrelas saírem da sequência principal (linha preta). A média de idade dos planetas habitáveis na Galáxia 
é de 8,24 Ga, com idade mais frequente de 12,45 Ga. Oitenta por cento dos planetas da Galáxia seriam mais velhos do que a Terra. Então, pensando na Galáxia como um todo, a Terra estaria entre as gerações mais jovens.

Lineweaver (2001) calculou uma idade média de 6,4(9) Ga para planetas habitáveis ao redor de estrelas como o Sol no Universo e que $74(9) \%$ deles seriam mais velhos do a Terra. Esses números se modificaram bastante em Lineweaver et al. (2004) ao se restringir à nossa Galáxia, encontrando uma idade média de $\sim 3,5$ Ga e somente $\sim 30 \%$ dos planetas habitáveis sendo mais velhos do que a Terra. Os resultados de Lineweaver et al. (2004) talvez sejam menos comparáveis aos nossos resultados por eles terem incluído a influência de supernovas e estarem mais preocupados com a vida dita complexa.

Fazendo uma análise mais local, encontramos um gradiente de idades médias. A distribuição de idades para o raio de 4 kpc é mais parecida com a do disco da Galáxia como um todo, com idade média de 8,51 Ga e 85\% dos planetas mais velhos do que a Terra. No raio de $8 \mathrm{kpc}$ a distribuição é bem diferente, com o pico mais próximo da idade da Terra, com 5,66 Ga e 59\% dos planetas mais velhos do que a Terra. No raio de $12 \mathrm{kpc}$, a média é de planetas mais jovens do que a Terra, com 4,03 Ga e 44\% dos planetas mais velhos do que a Terra. Esses resultados numéricos podem ter sido distorcidos pelo uso da IMF de Salpeter, mas o que eles apontam como um todo, não. A maioria dos planetas habitáveis na Via-Láctea são consideravelmente mais velhos do que a Terra.

Aqui há um impasse. Claramente há mais planetas habitáveis em direção ao centro da Galáxia, em raios mais internos, especialmente o de 2 kpc. Então essas regiões deveriam receber maior atenção dos programas de busca. No entanto, esses planetas também são os com idade média bem maior do que a Terra. O jeito como ponderamos a largura da ZHC fez os planetas menos massivos terem maior peso. Esses talvez fossem os que sofreriam mais com a idade de maneira ainda maior do que a que modelamos por perderem campo magnético e então atmosfera. Por conta disso, pode ser que haja menos planetas habitáveis nas regiões centrais do que nossos resultados apontam.

Nas partes externas do disco, a idade média diminui e os planetas acabam ficando em média mais jovens do que a Terra, o que promoveria sua habitabilidade. No entanto, também estariam em menor densidade e então seriam mais difíceis de serem encontrados. Como estamos analisando em relação às idades médias e as distribuições são bem largas ainda poderíamos encontrar planetas de todas as idades em todos os raios. 

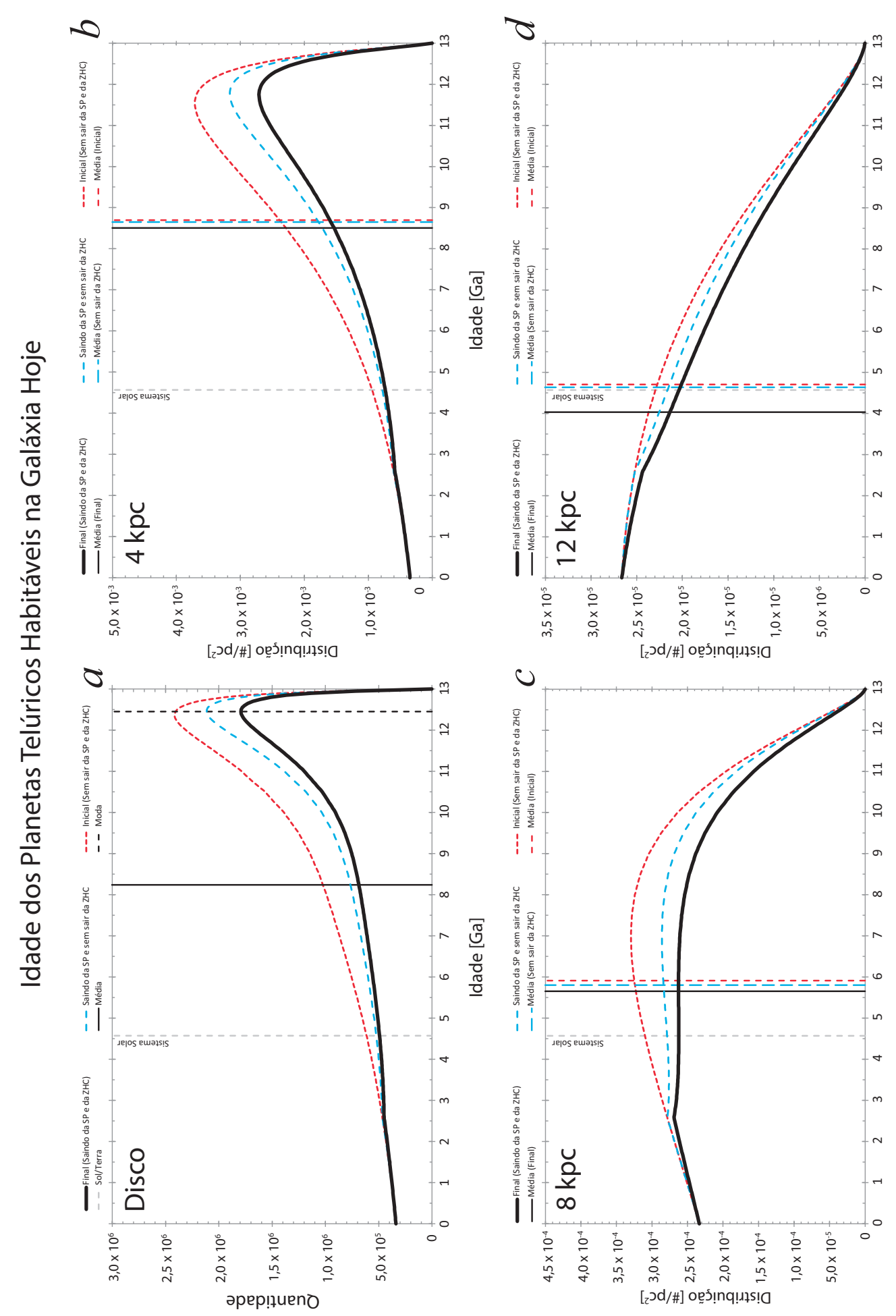

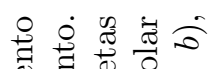

:

蛋

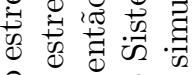

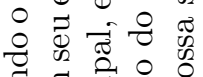

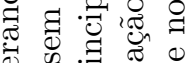

늄

궁

00 还

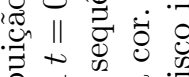

उु

营

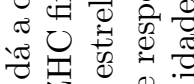

ส

凷

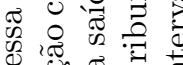

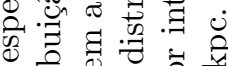

ช

焉

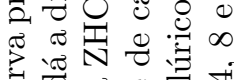
元它怘

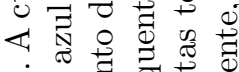

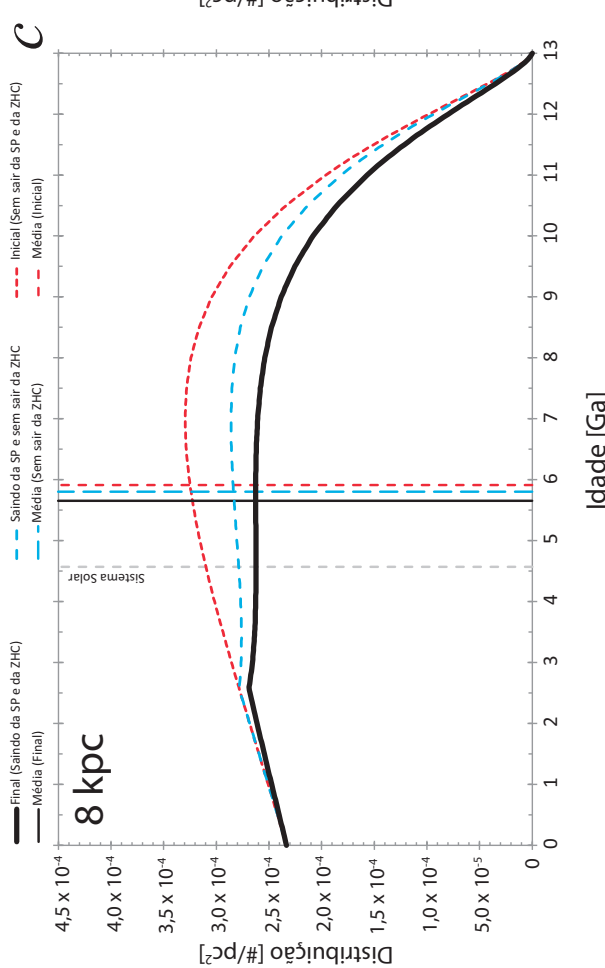

嵌它

I $\frac{\pi}{0}$ 需

论

जी

छ

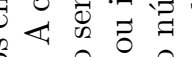

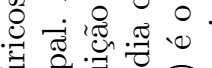

焉.

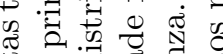

范

完娄

ช 엉

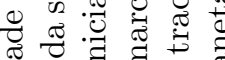

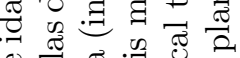

0

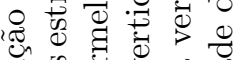

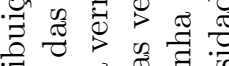

节 疋

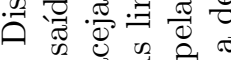

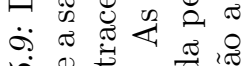

ن

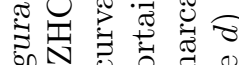

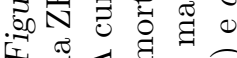




\subsubsection{Mapa da Habitabilidade}

A Figura 5.10a apresenta os resultados para a densidade de planetas telúricos habitáveis de maneira a dar uma melhor perspectiva da diferença entre densidades e da posição do raio Galactocêntrico solar e da época de formação da Terra. Nós estaríamos bem no limiar da região de maior densidade de planetas habitáveis. Essa distribuição parece ter surgido bem primitivamente e se mantido até hoje. A Figura $5.10 b$ apresenta os resultados para a época atual. As regiões de maior densidade de planetas habitáveis formam uma compacta região central, com a maior parte da área do disco da Galáxia permanecendo com baixíssima densidade de planetas habitáveis.

A Figura 5.11 é uma sobreposição da Figura $5.10 b$ à uma ilustração da Via-Láctea para contextualizar nossos resultados. A compacta região interna de maior densidade de planetas habitáveis se sobreporia parcialmente à barra central, com a maior parte dos braços espirais residindo nas regiões de menor densidade de planetas habitáveis. A barra central de nossa Galáxia influencia na órbita das estrelas e poderia alterar a distribuição de idade e metalicidade em suas partes mais internas (Sundin, 2006), então alterando a densidade de planetas habitáveis. Não temos como averiguar isso por não modelarmos dinâmica estelar, mas nosso gradiente de metalicidade (Figura 5.5) parece estar de acordo com a literatura num intervalo restrito de raios. Compare com a Figura 1.1, com a localização dos exoplanetas confirmados e de distância estimada. 


\section{Densidade de Planetas Telúricos Habitáveis na Galáxia}

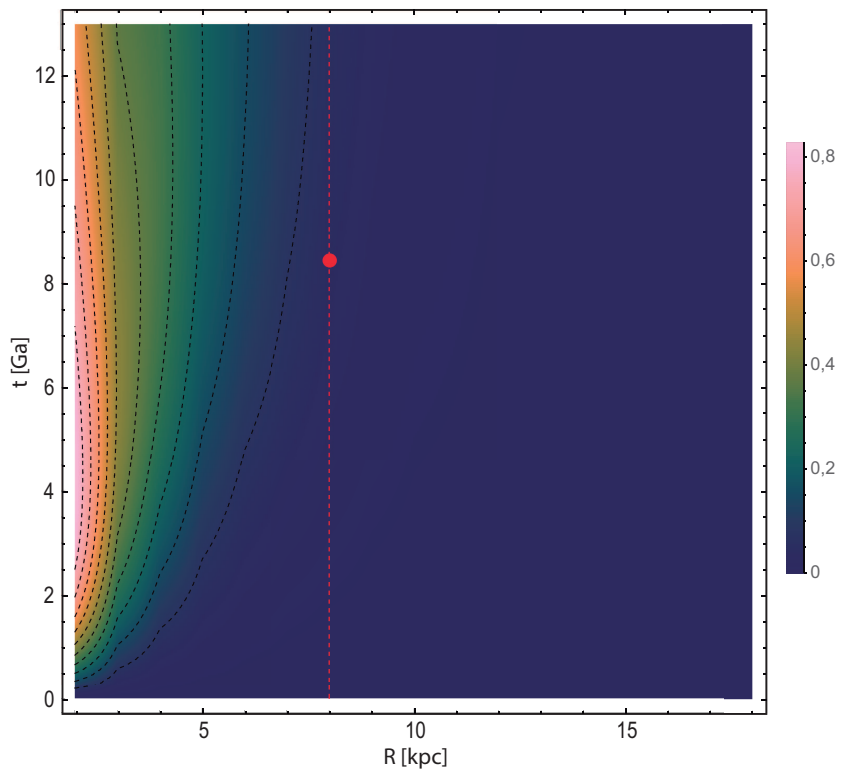

\section{Densidade de Planetas Telúricos Habitáveis na Galáxia Hoje}

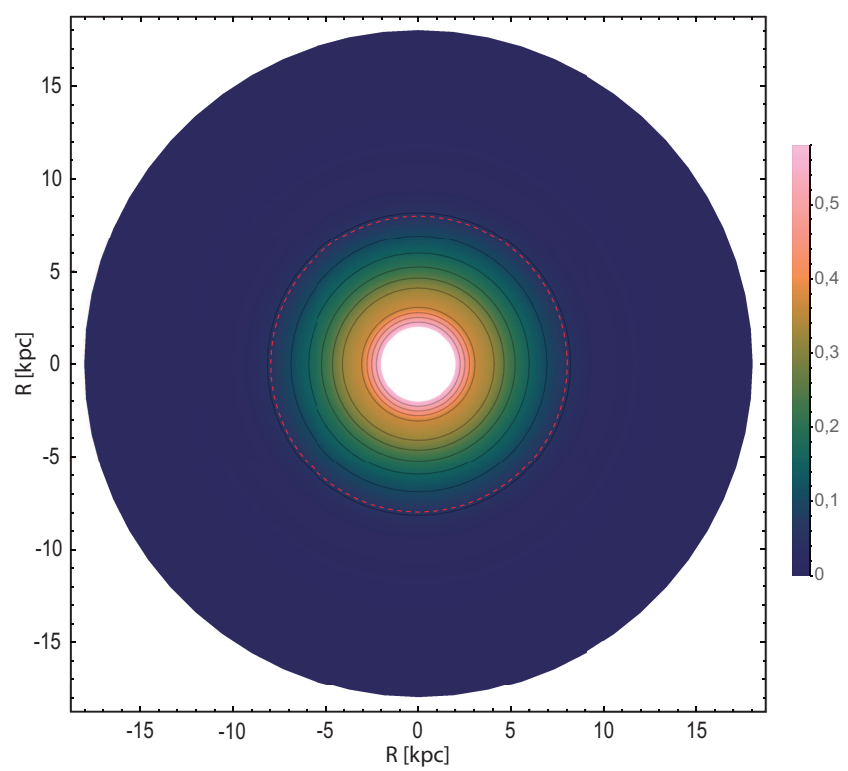

Figura 5.10: a) Densidade de planetas telúricos habitáveis por $p c^{2}$ no disco da Galáxia ao longo do tempo. b) $\mathrm{O}$ mesmo que $a$ ), mas para $t=13 \mathrm{Ga}$ (hoje). A linha tracejada vermelha marca o raio Galactocêntrico solar de $8 \mathrm{kpc}$ e o ponto vermelho marca a formação do Sistema Solar. 


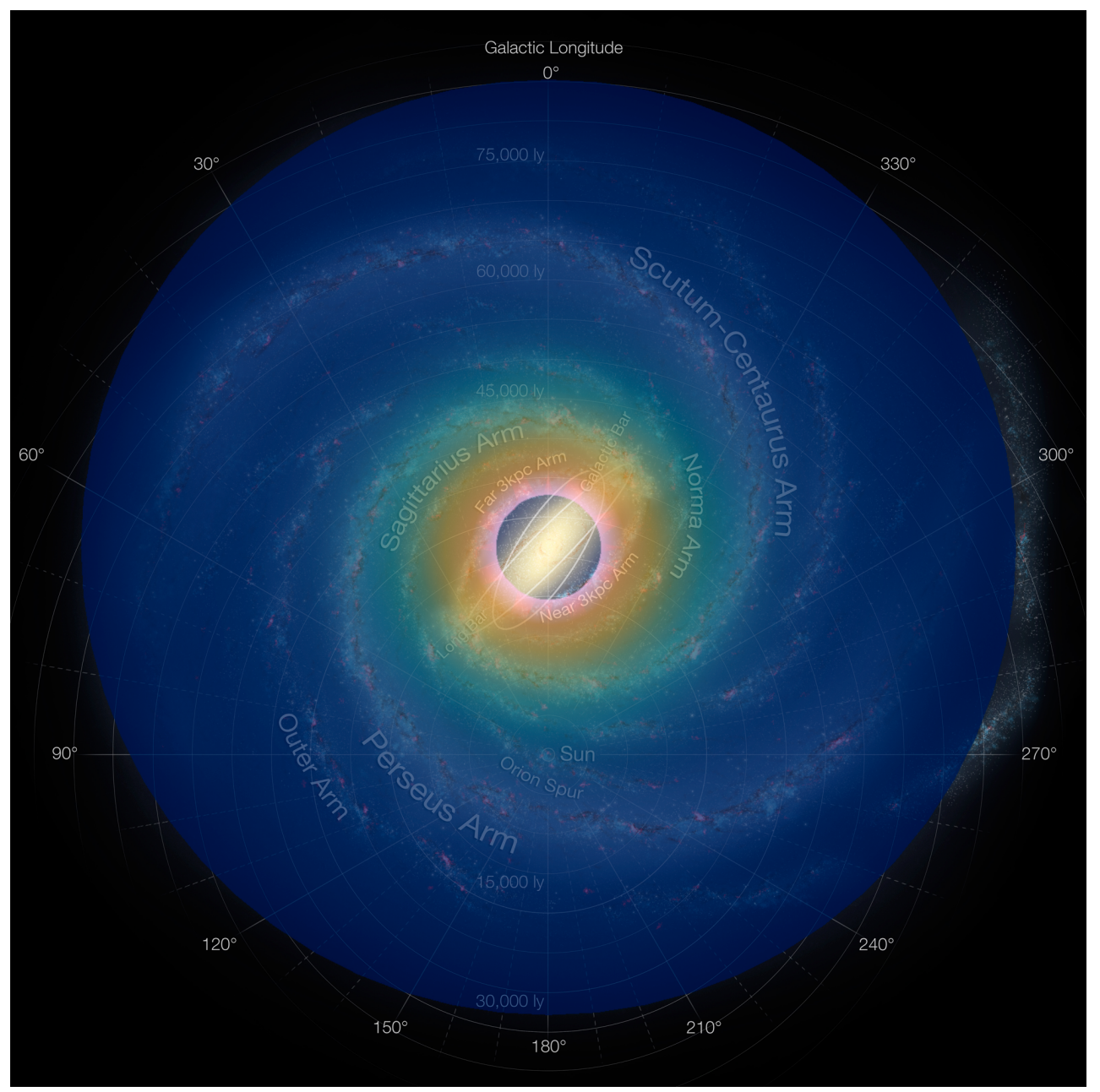

Figura 5.11: Ilustração do gradiente radial de densidade de planetas telúricos habitáveis na Galáxia hoje. Mesmo código de cores que na Figura 5.10b. Ilustração da Via-Láctea de NASA/JPL-Caltech/R. Hurt (SSC/Caltech).

\subsection{Conclusões Parciais}

De várias referências da literatura derivamos uma função para a fração de estrelas FGK com planetas telúricos habitáveis em função da metalicidade e massas estelares. A fração aumentaria para maiores metalicidades e massas estelares. Juntando com os resultados dos capítulos anteriores estimamos a densidade de planetas habitáveis radialmente e em função da idade da Galáxia. Os raios mais internos são os de maior densidade e número de planetas habitáveis e isso se manteve por toda a história da Galáxia. Essas regiões mais internas também são as de maior idade média dos planetas, o que poderia prejudicar sua habitabilidade. Mesmo assim, pela alta densidade e número de planetas habitáveis, essa região ainda é a mais indicada na busca por planetas habitáveis. 
Capítulo 6

\section{Conclusões}

Avaliamos em primeiras aproximações a habitabilidade da Via-Láctea em várias escalas de tempo, espaço e estrutura (planeta, estrela, sistema, Galáxia) para determinar as melhores estrelas e regiões para procurar por planetas telúricos habitáveis. Em escala planetária, a habitabilidade foi especificada de maneira abrangente, para a vida microbiana, e modelada em função das características do planeta, principalmente a temperatura superficial. Em escalas maiores, a habitabilidade foi especificada em função da maior ou menor formação e incidência de planetas habitáveis.

Para estudar a habitabilidade planetária desenvolvemos um modelo mínimo da coevolução da geosfera, atmosfera e biosfera de nosso planeta para avaliar suas condições ao longo de bilhões de anos e estimar a expectativa de vida da biosfera. A falta (ou excesso) de água por trocas gasosas entre o manto e a superfície não parece ter impactado negativamente na habitabilidade de nosso planeta e não será um fator definidor em seu futuro. A constante queda na concentração de $\mathrm{CO}_{2}$ na atmosfera impactará negativamente a biosfera cada vez mais ao atingir o limite para plantas C4 em 840 Ma. O aumento rápido das temperaturas será o fator limitante com a temperatura de $373 \mathrm{~K}$ sendo atingida em 1,63 Ga, bem antes do Sol engolir o planeta como gigante vermelha em 7,6 Ga.

Com pequenas modificações, utilizamos nosso modelo de habitabilidade da Terra para explorar o espaço de parâmetros e determinar alguns limites simples de habitabilidade para possíveis planetas terrestres. Nossos resultados indicam que tanto planetas mais massivos do que a Terra quanto planetas com maior abundância de material radioativo mais facilmente manteriam altos os indicadores de atividade geológica e a habitabilidade por longos períodos de tempo. A queda na temperatura do manto e da atividade geológica nos planetas terrestres ao longo do tempo parece ser um forte fator limitante na extensão 
da ZHC tradicional por limitar a $P_{\mathrm{CO}_{2}}$ na atmosfera. Então pode ser que a ZHC tradicional possa ser melhorada levando em conta mais parâmetros planetários e um coquetel de gases estufa mais complexo do que apenas água e dióxido de carbono.

Levamos nosso modelo para uma escala superior ao estudar a ZHC em função da massa planetária e, consultando a literatura, a frequência de planetas terrestres em função de parâmetros estelares. A largura da ZHC aumenta com a massa estelar e diminui com a idade da estrela/planeta, enquanto a fração de estrelas FGK com planetas terrestres cresce com a metalicidade e a massa estelar.

Um modelo da evolução química da Galáxia nos permitiu aplicar nossos modelos e derivações à escala Galáctica, obtendo a densidade de planetas habitáveis em função do raio Galactocêntrico e da idade da Galáxia. Conservadoramente, 190 milhões de planetas habitáveis existiriam na Via-Láctea atual, $\sim 2 / 3$ residindo em raios internos a $7 \mathrm{kpc}$, os com maior densidade de planetas habitáveis, especialmente o raio de $2 \mathrm{kpc}$. Os planetas dessas regiões mais internas são os de maior idade média, o que poderia prejudicar sua habitabilidade. Com $80 \%$ dos planetas habitáveis do disco da Galáxia sendo mais velhos do que a Terra, a expectativa mais geral é de encontrarmos planetas velhos.

Nossa escala de trabalho é vasta e nossos modelos e derivações são primeiras aproximações e limitados em escopo. Há bastante espaço para expandir e melhorar os modelos em todas as escalas trabalhadas. Em especial, na escala Galáctica, incluir isótopos radioativos no MEQ para averiguar a possível existência de um gradiente radial desses isótopos na Galáxia e a mudança de sua abundância com o tempo, e estudar os efeitos que supernovas e outros eventos exterilizantes podem ter em planetas rochosos que não apenas a destruição parcial de camadas de ozônio. Em escala estelar, estudar mais profundamente o efeito que planetas gigantes podem ter em planetas rochosos no mesmo sistema e expandir o intervalo de massas estelares estudado em direção às estrelas $\mathrm{M}$, de baixa massa. Em escala planetária e terrestre, considerar a erosão de atmosferas por vento estelar e a influência que o campo magnético planetário teria nesse processo, incluir isótopos radioativos de meia-vida curta e averiguar seu efeito no aquecimento primordial do manto, também incluir metano e outros gases estufa no modelo atmosférico para lidar melhor com o problema do Sol jovem fraco, e alterar a equação de viscosidade do manto para depender também da quantidade de água no manto, talvez servindo como um mecanismo de estabilidade geológica.

Achamos que nossos resultados mais gerais são robustos, indicando que estrelas jovens, 
mais metálicas e mais ricas em isótopos radioativos teriam mais chances de abrigar planetas habitáveis. Essas estrelas não seriam a maioria da população das partes mais internas da Galáxia, mas a alta densidade e grande número de planetas compensariam essa deficiência fazendo a região ser a melhor para buscar por planetas habitáveis na Via-Láctea atual. 


\section{Referências Bibliográficas}

Abbot D. S., Switzer E. R., The Steppenwolf: a proposal for a habitable planet in interstellar space, The Astrophysical Journal Letters, 2011, vol. 735, p. L27

Abbot D. S., wan N. B., Ciesla F. J., Indication of insensitivity of planetary weathering behavior and habitable zone to surface land fraction, The Astrophysical Journal, 2012, vol. 756 , p. 178

Abbott D., Burgess L., Longhi J., Smith W. H., An empirical thermal history of the Earth's upper mantle, Journal of Geophysical Research: Solid Earth, 1994, vol. 99, p. 13835

Abe Y., Abe-Ouchi A., Sleep N. H., Zahnle K. J., Habitable zone limits for dry planets, Astrobiology, 2011, vol. 11, p. 443

Abe Y., Ohtani E., Okuchi T., Righter K., Drake M., Water in the early Earth, Origin of the Earth and Moon, 2000, pp 413-433

Abrevaya X. C., Paulino-Lima I. G., Galante D., Rodrigues F., Mauas P. J., Cortón E., Lage C. d. A. S., Comparative survival analysis of Deinococcus radiodurans and the Haloarchaea Natrialba magadii and Haloferax volcanii exposed to vacuum ultraviolet irradiation, Astrobiology, 2011, vol. 11, p. 1034

Ahrens T. J., Water storage in the mantle, Nature, 1989, vol. 342, p. 122

Alcántara-Díaz D., Breña-Valle M., Serment-Guerrero J., Divergent adaptation of Escherichia coli to cyclic ultraviolet light exposures, Mutagenesis, 2004, vol. 19, p. 349

Alibert Y., Mordasini C., Benz W., Extrasolar planet population synthesis-III. Formation 
of planets around stars of different masses, Astronomy \& Astrophysics, 2011, vol. 526, p. A63

Alvarez L. W., Alvarez W., Asaro F., Michel H. V., Extraterrestrial cause for the Cretaceous-Tertiary extinction, Science, 1980, vol. 208, p. 1095

Amelin Y., Krot A. N., Hutcheon I. D., Ulyanov A. A., Lead isotopic ages of chondrules and calcium-aluminum-rich inclusions, Science, 2002, vol. 297, p. 1678

Annis J., An astrophysical explanation for the great silence, JBIS, 1999, vol. 52, p. 19

Arevalo Jr R., McDonough W. F., Luong M., The K/U ratio of the silicate Earth: Insights into mantle composition, structure and thermal evolution, Earth and Planetary Science Letters, 2009, vol. 278, p. 361

Badescu V., Free-floating planets as potential seats for aqueous and non-aqueous life, Icarus, 2011, vol. 216, p. 485

Baker J., Bizzarro M., Wittig N., Connelly J., Haack H., Early planetesimal melting from an age of 4.5662 Gyr for differentiated meteorites, Nature, 2005, vol. 436, p. 1127

Balazs B., , 1988 in , Bioastronomy-The Next Steps. Springer pp 61-66

Baraffe I., Chabrier G., Allard F., Hauschildt P., Evolutionary models for solar metallicity low-mass stars: mass-magnitude relationships and color-magnitude diagrams, Astronomy and Astrophysics, 1998, vol. 337, p. 403

Baraffe I., Selsis F., Chabrier G., Barman T. S., Allard F., Hauschildt P., Lammer H., The effect of evaporation on the evolution of close-in giant planets, Astronomy \& Astrophysics, 2004, vol. 419, p. L13

Bell E. A., Boehnke P., Harrison T. M., Mao W. L., Potentially biogenic carbon preserved in a 4.1 billion-year-old zircon, Proceedings of the National Academy of Sciences, 2015, vol. 112 , p. 14518

Benitez N., Maíz-Apellániz J., Canelles M., Evidence for nearby supernova explosions, Physical Review Letters, 2002, vol. 88, p. 081101 
Berner R. A., Atmospheric carbon dioxide levels over Phanerozoic time, Science, 1990, vol. 249 , p. 1382

Berner R. A., The Phanerozoic carbon cycle: CO2 and O2. Oxford University Press on Demand, 2004

Bevis M., The curvature of Wadati-Benioff zones and the torsional rigidity of subducting plates, Nature, 1986, vol. 323, p. 52

Biggin A. J., Piispa E., Pesonen L. J., Holme R., Paterson G., Veikkolainen T., Tauxe L., Palaeomagnetic field intensity variations suggest Mesoproterozoic inner-core nucleation, Nature, 2015, vol. 526, p. 245

Birmingham B. C., Colman B., Measurement of carbon dioxide compensation points of freshwater algae, Plant Physiology, 1979, vol. 64, p. 892

Blake R. E., Chang S. J., Lepland A., Phosphate oxygen isotopic evidence for a temperate and biologically active Archaean ocean, Nature, 2010, vol. 464, p. 1029

Bono R. K., Tarduno J. A., Nimmo F., Cottrell R. D., Young inner core inferred from Ediacaran ultra-low geomagnetic field intensity, Nature Geoscience, 2019, vol. 12, p. 143

Botelho R. B., Milone A. d. C., Melendez J., Bedell M., Spina L., Asplund M., dos Santos L., Bean J. L., Ramírez I., Yong D., et al., Thorium in solar twins: implications for habitability in rocky planets, Monthly Notices of the Royal Astronomical Society, 2018, vol. 482 , p. 1690

Bounama C., Franck S., Bloh W. v., The fate of Earth's ocean, Hydrology and Earth System Sciences, 2001, vol. 5, p. 569

Bounama C., Von Bloh W., Franck S., How rare is complex life in the Milky Way?, Astrobiology, 2007, vol. 7, p. 745

Bowes G., Facing the inevitable: plants and increasing atmospheric CO2, Annual review of plant biology, 1993, vol. 44, p. 309

Bromley B. C., Kenyon S. J., Planet formation around binary stars: Tatooine made easy, The Astrophysical Journal, 2015, vol. 806, p. 98 
Buchhave L. A., Latham D. W., Johansen A., Bizzarro M., Torres G., Rowe J. F., Batalha N. M., Borucki W. J., Brugamyer E., Caldwell C., et al., An abundance of small exoplanets around stars with a wide range of metallicities, Nature, 2012, vol. 486, p. 375

Buffett B. A., Earth's core and the geodynamo, Science, 2000, vol. 288, p. 2007

Byrne B., Goldblatt C., Radiative forcings for 28 potential Archean greenhouse gases, arXiv preprint arXiv:1409.1880, 2014

Caldeira K., Kasting J. F., The life span of the biosphere revisited, Nature, 1992, vol. 360, p. 721

Cautun M., Deason A. J., Frenk C. S., McAlpine S., The aftermath of the Great Collision between our Galaxy and the Large Magellanic Cloud, Monthly Notices of the Royal Astronomical Society, 2018, vol. 483, p. 2185

Cerling T. E., Dearing M. D., Ehleringer J. R., A history of atmospheric $\mathrm{CO}_{2}$ and its effects on plants, animals, and ecosystems. Springer, 2005

Chamberlain J. W., Changes in the planetary heat balance with chemical changes in air, Planetary and Space Science, 1980, vol. 28, p. 1011

Chamberlain T. P., Hunten D. M., Theory of planetary atmospheres: an introduction to their physics and chemistry. vol. 36, Academic Press, 1990

Chiappini C., Gratton R., The chemical evolution of the galaxy: the two-infall model, The Astrophysical Journal, 1997, vol. 477, p. 765

Christensen U. R., Thermal evolution models for the Earth, Journal of Geophysical Research: Solid Earth, 1985, vol. 90, p. 2995

Cleaves H. J., Miller S. L., Oceanic protection of prebiotic organic compounds from UV radiation, Proceedings of the National Academy of Sciences, 1998, vol. 95, p. 7260

Cockell C. S., Raven J. A., Ozone and life on the Archaean Earth, Philosophical Transactions of the Royal Society A: Mathematical, Physical and Engineering Sciences, 2007, vol. 365, p. 1889 
Colbourn G., Ridgwell A., Lenton T., The time scale of the silicate weathering negative feedback on atmospheric $\mathrm{CO}_{2}$, Global Biogeochemical Cycles, 2015, vol. 29, p. 583

Conrad C. P., Hager B. H., Effects of plate bending and fault strength at subduction zones on plate dynamics, Journal of Geophysical Research: Solid Earth, 1999a, vol. 104, p. 17551

Conrad C. P., Hager B. H., The thermal evolution of an Earth with strong subduction zones, Geophysical Research Letters, 1999b, vol. 26, p. 3041

Coohill T. P., Sagripanti J.-L., Overview of the inactivation by $254 \mathrm{~nm}$ ultraviolet radiation of bacteria with particular relevance to biodefense, Photochemistry and photobiology, 2008, vol. 84, p. 1084

Cowan N. B., Abbot D. S., Water cycling between ocean and mantle: super-Earths need not be waterworlds, The Astrophysical Journal, 2014, vol. 781, p. 27

Cowen R., History of life. John Wiley \& Sons, 2005

Dai L., Karato S.-i., Electrical conductivity of wadsleyite at high temperatures and high pressures, Earth and Planetary Science Letters, 2009, vol. 287, p. 277

Dalrymple G. B., The age of the Earth in the twentieth century: a problem (mostly) solved, Geological Society, London, Special Publications, 2001, vol. 190, p. 205

Davies G. F., Thermal histories of convective Earth models and constraints on radiogenic heat production in the Earth, Journal of Geophysical Research: Solid Earth, 1980, vol. 85 , p. 2517

de Wit M. J., Furnes H., 3.5-Ga hydrothermal fields and diamictites in the Barberton Greenstone Belt-Paleoarchean crust in cold environments, Science advances, 2016, vol. 2, p. e1500368

Dehant V., Lammer H., Kulikov Y. N., Grießmeier J.-M., Breuer D., Verhoeven O., Karatekin Ö., Van Hoolst T., Korablev O., Lognonné P., Planetary magnetic dynamo effect on atmospheric protection of early Earth and Mars, Space Science Reviews, 2007, vol. 129, p. 279 
Dole S. H., Habitable planets for man. Blaisdell Pub, 1964

Dong S., Zhu Z., Fast rise of "Neptune-size" planets (4-8 $\left.\mathrm{R}_{\text {Earth }}\right)$ from P $\sim 10$ to $\sim 250$ days - statistics of Kepler planet candidates up to 0.75 AU, The Astrophysical Journal, 2013, vol. 778 , p. 53

Dressing C. D., Charbonneau D., The occurrence rate of small planets around small stars, The Astrophysical Journal, 2013, vol. 767, p. 95

Driese S. G., Jirsa M. A., Ren M., Brantley S. L., Sheldon N. D., Parker D., Schmitz M., Neoarchean paleoweathering of tonalite and metabasalt: implications for reconstructions of 2.69 Ga early terrestrial ecosystems and paleoatmospheric chemistry, Precambrian Research, 2011, vol. 189, p. 1

Driscoll P., Geodynamo recharged, Nature Geoscience, 2019, vol. 12, p. 83

Driscoll P., Bercovici D., Divergent evolution of Earth and Venus: influence of degassing, tectonics, and magnetic fields, Icarus, 2013, vol. 226, p. 1447

Duchêne G., Kraus A., Stellar multiplicity, Annual Review of Astronomy and Astrophysics, 2013, vol. 51, p. 269

Eggl S., Pilat-Lohinger E., Funk B., Georgakarakos N., Haghighipour N., Circumstellar habitable zones of binary-star systems in the solar neighbourhood, Monthly Notices of the Royal Astronomical Society, 2012, vol. 428, p. 3104

Eggl S., Pilat-Lohinger E., Georgakarakos N., Gyergyovits M., Funk B., An analytic method to determine habitable zones for S-type planetary orbits in binary star systems, The Astrophysical Journal, 2012, vol. 752, p. 74

Erkaev N., Kulikov Y. N., Lammer H., Selsis F., Langmayr D., Jaritz G., Biernat H., Roche lobe effects on the atmospheric loss from "Hot Jupiters", Astronomy \& Astrophysics, 2007, vol. 472, p. 329

Etiope G., Klusman R. W., Geologic emissions of methane to the atmosphere, Chemosphere, 2002, vol. 49, p. 777

Ewing D., The directed evolution of radiation resistance in E. coli, Biochemical and biophysical research communications, 1995, vol. 216, p. 549 
Feulner G., The faint young Sun problem, Reviews of Geophysics, 2012, vol. 50

Fields B. D., Ellis J., On deep-ocean ${ }^{60} \mathrm{Fe}$ as a fossil of a near-earth supernova, New Astronomy, 1999, vol. 4, p. 419

Fischer D. A., Valenti J., The planet-metallicity correlation, The Astrophysical Journal, 2005, vol. 622, p. 1102

Fogg M. J., An Estimate of the Prevalence of Biocompatible and Habitable Planets, Journal of the British Interplanetary Society, 1992, vol. 45, p. 3

Fogg M. J., Nelson R. P., On the possibility of terrestrial planet formation in hot-Jupiter systems, International Journal of Astrobiology, 2006, vol. 5, p. 199

Foley B. J., The role of plate tectonic-climate coupling and exposed land area in the development of habitable climates on rocky planets, The Astrophysical Journal, 2015, vol. 812 , p. 36

Fortney J. J., Marley M. S., Barnes J. W., Planetary radii across five orders of magnitude in mass and stellar insolation: application to transits, The Astrophysical Journal, 2007, vol. 659 , p. 1661

Foster G. L., Royer D. L., Lunt D. J., Future climate forcing potentially without precedent in the last 420 million years, Nature Communications, 2017, vol. 8, p. 14845

Franck S., Evolution of the global mean heat flow over 4.6 Gyr, Tectonophysics, 1998, vol. 291 , p. 9

Franck S., Block A., Von Bloh W., Bounama C., Schellnhuber H., Svirezhev Y., Reduction of biosphere life span as a consequence of geodynamics, Tellus B, 2000a, vol. 52, p. 94

Franck S., Block A., Von Bloh W., Bounama C., Schellnhuber H.-J., Planetary habitability: estimating the number of Gaias in the Milky Way. In Exo-/Astro-Biology, vol. 496, 2001, p. 73

Franck S., Block A., Von Bloh W., Bounama C., Schellnhuber H.-J., Svirezhev Y., Habitable zone for Earth-like planets in the solar system, Planetary and Space Science, 2000b, vol. 48, p. 1099 
Franck S., Bounama C., Effects of water-dependent creep rate on the volatile exchange between mantle and surface reservoirs, Physics of the earth and planetary interiors, 1995, vol. 92 , p. 57

Franck S., Bounama C., Continental growth and volatile exchange during Earth's evolution, Physics of the earth and planetary interiors, 1997, vol. 100, p. 189

Franck S., Bounama C., Von Bloh W., Causes and timing of future biosphere extinctions, Biogeosciences, 2006, vol. 3, p. 85

Franck S., Cuntz M., Von Bloh W., Bounama C., The habitable zone of Earth-mass planets around 47 UMa: results for land and water worlds, International Journal of Astrobiology, 2003, vol. 2, p. 35

Franck S., Kossacki K., Bounama C., Modelling the global carbon cycle for the past and future evolution of the earth system, Chemical Geology, 1999, vol. 159, p. 305

Franck S., Kossacki K. J., Von Bloth W., Bounama C., Long-term evolution of the global carbon cycle: historic minimum of global surface temperature at presen, Tellus B: Chemical and Physical Meteorology, 2002, vol. 54, p. 325

Frank S. A., The invariances of power law size distributions, F1000Research, 2016, vol. 5

Fressin F., Torres G., Charbonneau D., Bryson S. T., Christiansen J., Dressing C. D., Jenkins J. M., Walkowicz L. M., Batalha N. M., The false positive rate of Kepler and the occurrence of planets, The Astrophysical Journal, 2013, vol. 766, p. 81

Galante D., Efeitos astrofísicos e astrobiológicos de gamma-ray bursts, Instituto de Astronomia, Geofísica e Ciências Atmosféricas da Universidade de São Paulo, 2009, Tese de Doutorado

Gascón J., Oubiña A., Pérez-Lezaun A., Urmeneta J., Sensitivity of selected bacterial species to UV radiation, Current microbiology, 1995, vol. 30, p. 177

Gehrels N., Laird C. M., Jackman C. H., Cannizzo J. K., Mattson B. J., Chen W., Ozone depletion from nearby supernovae, The Astrophysical Journal, 2003, vol. 585, p. 1169

Genda H., Origin of Earth's oceans: an assessment of the total amount, history and supply of water, Geochemical Journal, 2016, vol. 50, p. 27 
Godolt M., Grenfell J., Kitzmann D., Kunze M., Langematz U., Patzer A., Rauer H., Stracke B., Assessing the habitability of planets with Earth-like atmospheres with 1D and 3D climate modeling, Astronomy \& Astrophysics, 2016, vol. 592, p. A36

Gold T., The deep, hot biosphere, Proceedings of the National Academy of Sciences, 1992, vol. 89 , p. 6045

Goldblatt C., Zahnle K., Clouds and the Faint Young Sun Paradox., Climate of the Past Discussions, 2011, vol. 6

Goldman R. P., Travisano M., Experimental evolution of ultraviolet radiation resistance in Escherichia coli, Evolution: International Journal of Organic Evolution, 2011, vol. 65, p. 3486

Gomes R., Levison H. F., Tsiganis K., Morbidelli A., Origin of the cataclysmic Late Heavy Bombardment period of the terrestrial planets, Nature, 2005, vol. 435, p. 466

Gonzalez G., Brownlee D., Ward P., The galactic habitable zone: galactic chemical evolution, Icarus, 2001, vol. 152, p. 185

Gough D., , 1981 in , Physics of Solar Variations. Springer pp 21-34

Gowanlock M. G., Patton D. R., McConnell S. M., A model of habitability within the Milky Way Galaxy, Astrobiology, 2011, vol. 11, p. 855

Guo J., Zhang F., Chen X., Han Z., Probability distribution of terrestrial planets in habitable zones around host stars, Astrophysics and Space Science, 2009, vol. 323, p. 367

Güsten R., Mezger P., Star formation and abundance gradients in the galaxy, Vistas in Astronomy, 1982, vol. 26, p. 159

Habets G., Heintze J., Empirical bolometric corrections for the main-sequence, Astronomy and Astrophysics Supplement Series, 1981, vol. 46, p. 193

Haghighipour N., Planets in Binary Star Systems. vol. 366, Springer, 2010

Haghighipour N., Raymond S. N., Habitable planet formation in binary planetary systems, The Astrophysical Journal, 2007, vol. 666, p. 436 
Halliday A. N., Terrestrial accretion rates and the origin of the Moon, Earth and Planetary Science Letters, 2000, vol. 176, p. 17

Hansen C. J., Kawaler S. D., Trimble V., Stellar interiors: physical principles, structure, and evolution. Springer Science \& Business Media, 2012

Hansen J., Sato M., Russell G., Kharecha P., Climate sensitivity, sea level and atmospheric carbon dioxide, Philosophical Transactions of the Royal Society A: Mathematical, Physical and Engineering Sciences, 2013, vol. 371, p. 20120294

Haqq-Misra J. D., Domagal-Goldman S. D., Kasting P. J., Kasting J. F., A revised, hazy methane greenhouse for the Archean Earth, Astrobiology, 2008, vol. 8, p. 1127

Hart M. H., Habitable zones about main sequence stars, Icarus, 1979, vol. 37, p. 351

Heath M. J., Doyle L. R., Joshi M. M., Haberle R. M., Habitability of planets around red dwarf stars, Origins of Life and Evolution of the Biosphere, 1999, vol. 29, p. 405

Herzberg C., Condie K., Korenaga J., Thermal history of the Earth and its petrological expression, Earth and Planetary Science Letters, 2010, vol. 292, p. 79

Hessler A. M., Lowe D. R., Jones R. L., Bird D. K., A lower limit for atmospheric carbon dioxide levels 3.2 billion years ago, Nature, 2004, vol. 428, p. 736

Hijnen W., Beerendonk E., Medema G. J., Inactivation credit of UV radiation for viruses, bacteria and protozoan (oo) cysts in water: a review, Water research, 2006, vol. 40, p. 3

Hohlfeld R. G., Terzian Y., Multiple stars and the number of habitable planets in the Galaxy, Icarus, 1977, vol. 30, p. 598

Holman M. J., Wiegert P. A., Long-term stability of planets in binary systems, The Astronomical Journal, 1999, vol. 117, p. 621

Howard A. W., Marcy G. W., Bryson S. T., Jenkins J. M., Rowe J. F., Batalha N. M., Borucki W. J., Koch D. G., Dunham E. W., Gautier III T. N., et al., Planet occurrence within 0.25 AU of solar-type stars from Kepler, The Astrophysical Journal Supplement Series, 2012, vol. 201, p. 15 
Hren M., Tice M., Chamberlain C., Oxygen and hydrogen isotope evidence for a temperate climate 3.42 billion years ago, Nature, 2009, vol. 462, p. 205

Huang S.-S., The problem of life in the universe and the mode of star formation, Publications of the Astronomical Society of the Pacific, 1959, vol. 71, p. 421

Huang S.-S., Life-supporting regions in the vicinity of binary systems, Publications of the Astronomical Society of the Pacific, 1960, vol. 72, p. 106

Iben Jr I., Stellar Evolution. VII. The Evolution of a $2.25 \mathrm{M}_{-}\{$sun $\}$Star from the Main Sequence to the Helium-Burning Phase, The Astrophysical Journal, 1967a, vol. 147, p. 650

Iben Jr I., Stellar evolution within and off the main sequence, Annual Review of Astronomy and Astrophysics, 1967b, vol. 5, p. 571

Ida S., Lin D., Toward a deterministic model of planetary formation. III. Mass distribution of short-period planets around stars of various masses, The Astrophysical Journal, 2005, vol. 626 , p. 1045

Jabłoński S., Rodowicz P., Łukaszewicz M., Methanogenic archaea database containing physiological and biochemical characteristics, International journal of systematic and evolutionary microbiology, 2015, vol. 65, p. 1360

Jambon A., Zimmermann J. L., Water in oceanic basalts: evidence for dehydration of recycled crust, Earth and Planetary Science Letters, 1990, vol. 101, p. 323

Jaupart C., Labrosse S., Mareschal J., 7.06-temperatures, heat and energy in the mantle of the earth, Treatise on geophysics, 2007, vol. 7, p. 223

Johnson J. A., Aller K. M., Howard A. W., Crepp J. R., Giant planet occurrence in the stellar mass-metallicity plane, Publications of the Astronomical Society of the Pacific, 2010, vol. 122 , p. 905

Johnson J. L., Li H., The first planets: the critical metallicity for planet formation, The Astrophysical Journal, 2012, vol. 751, p. 81

Joux F., Jeffrey W. H., Lebaron P., Mitchell D. L., Marine bacterial isolates display diverse responses to UV-B radiation, Appl. Environ. Microbiol., 1999, vol. 65, p. 3820 
Kaltenegger L., Haghighipour N., Calculating the habitable zone of binary star systems. I. S-type binaries, The Astrophysical Journal, 2013, vol. 777, p. 165

Kane S. R., Hinkel N. R., On the habitable zones of circumbinary planetary systems, The Astrophysical Journal, 2012, vol. 762, p. 7

Karhu J., Epstein S., The implication of the oxygen isotope records in coexisting cherts and phosphates, Geochimica et Cosmochimica Acta, 1986, vol. 50, p. 1745

Kasting J. F., Runaway and moist greenhouse atmospheres and the evolution of Earth and Venus, Icarus, 1988, vol. 74, p. 472

Kasting J. F., Earth's early atmosphere, Science, 1993, vol. 259, p. 920

Kasting J. F., Methane and climate during the Precambrian era, Precambrian Research, 2005, vol. 137, p. 119

Kasting J. F., Pollack J. B., Ackerman T. P., Response of Earth's atmosphere to increases in solar flux and implications for loss of water from Venus, Icarus, 1984, vol. 57, p. 335

Kasting J. F., Whitmire D. P., Reynolds R. T., Habitable zones around main sequence stars, Icarus, 1993, vol. 101, p. 108

Katsura T., Yamada H., Nishikawa O., Song M., Kubo A., Shinmei T., Yokoshi S., Aizawa Y., Yoshino T., Walter M. J., et al., Olivine-wadsleyite transition in the system $(\mathrm{Mg}$, Fe) 2SiO4, Journal of Geophysical Research: Solid Earth, 2004, vol. 109

Kaufman A. J., Xiao S., High CO 2 levels in the Proterozoic atmosphere estimated from analyses of individual microfossils, Nature, 2003, vol. 425, p. 279

Keeley J. E., CAM photosynthesis in submerged aquatic plants, The Botanical Review, 1998, vol. 64, p. 121

Keeley J. E., Busch G., Carbon assimilation characteristics of the aquatic CAM plant, Isoetes howellii, Plant Physiology, 1984, vol. 76, p. 525

Kite E. S., Manga M., Gaidos E., Geodynamics and rate of volcanism on massive Earth-like planets, The Astrophysical Journal, 2009, vol. 700, p. 1732 
Kitzmann D., Patzer A., von Paris P., Godolt M., Stracke B., Gebauer S., Grenfell J., Rauer H., Clouds in the atmospheres of extrasolar planets-I. Climatic effects of multilayered clouds for Earth-like planets and implications for habitable zones, Astronomy \& Astrophysics, 2010, vol. 511, p. A66

Knauth L. P., Lowe D. R., High Archean climatic temperature inferred from oxygen isotope geochemistry of cherts in the 3.5 Ga Swaziland Supergroup, South Africa, Geological Society of America Bulletin, 2003, vol. 115, p. 566

Konôpková Z., McWilliams R. S., Gómez-Pérez N., Goncharov A. F., Direct measurement of thermal conductivity in solid iron at planetary core conditions, Nature, 2016, vol. 534, p. 99

Kopparapu R. K., Ramirez R., Kasting J. F., Eymet V., Robinson T. D., Mahadevan S., Terrien R. C., Domagal-Goldman S., Meadows V., Deshpande R., Habitable zones around main-sequence stars: new estimates, The Astrophysical Journal, 2013, vol. 765, p. 131

Korenaga J., Energetics of mantle convection and the fate of fossil heat, Geophysical Research Letters, 2003, vol. 30

Korenaga J., Archean geodynamics and the thermal evolution of Earth, Geophysical Monograph-American Geophysical Union, 2006, vol. 164, p. 7

Korenaga J., Urey ratio and the structure and evolution of Earth's mantle, Reviews of Geophysics, 2008, vol. 46

Korenaga J., On the likelihood of plate tectonics on super-Earths: does size matter?, The Astrophysical Journal Letters, 2010, vol. 725, p. L43

Korenaga J., Plate tectonics and planetary habitability: current status and future challenges, Annals of the New York Academy of Sciences, 2012, vol. 1260, p. 87

Korenaga J., Initiation and evolution of plate tectonics on Earth: theories and observations, Annual review of earth and planetary sciences, 2013, vol. 41, p. 117 
Krisko A., Radman M., Protein damage and death by radiation in Escherichia coli and Deinococcus radiodurans, Proceedings of the National Academy of Sciences, 2010, vol. 107, p. 14373

Kroupa P., On the variation of the initial mass function, Monthly Notices of the Royal Astronomical Society, 2001, vol. 322, p. 231

Kuramoto K., Umemoto T., Ishiwatari M., Effective hydrodynamic hydrogen escape from an early Earth atmosphere inferred from high-accuracy numerical simulation, Earth and Planetary Science Letters, 2013, vol. 375, p. 312

Kurokawa H., Foriel J., Laneuville M., Houser C., Usui T., Subduction and atmospheric escape of Earth's seawater constrained by hydrogen isotopes, Earth and Planetary Science Letters, 2018, vol. 497, p. 149

Labrosse S., Jaupart C., Thermal evolution of the Earth: Secular changes and fluctuations of plate characteristics, Earth and Planetary Science Letters, 2007, vol. 260, p. 465

Labrosse S., Poirier J.-P., Le Mouël J.-L., The age of the inner core, Earth and Planetary Science Letters, 2001, vol. 190, p. 111

Lacey C., Fall S., Chemical evolution of the galactic disk with radial gas flows., Astrophysical journal., 1985, vol. 290, p. 154

Lammer H., Odert P., Leitzinger M., Khodachenko M., Panchenko M., Kulikov Y. N., Zhang T., Lichtenegger H., Erkaev N., Wuchterl G., et al., Determining the mass loss limit for close-in exoplanets: what can we learn from transit observations?, Astronomy \& Astrophysics, 2009, vol. 506, p. 399

Lanfranchi G. A., Friaça A. C., Clues to the nature of damped Lyman $\alpha$ systems from chemical evolution models, Monthly Notices of the Royal Astronomical Society, 2003, vol. 343, p. 481

Leconte J., Forget F., Charnay B., Wordsworth R., Pottier A., Increased insolation threshold for runaway greenhouse processes on Earth-like planets, Nature, 2013, vol. 504, p. 268 
Lehtola M. J., Miettinen I. T., Vartiainen T., Rantakokko P., Hirvonen A., Martikainen P. J., Impact of UV disinfection on microbially available phosphorus, organic carbon, and microbial growth in drinking water, Water Research, 2003, vol. 37, p. 1064

Lenardic A., Cooper C., Moresi L., A note on continents and the Earth's Urey ratio, Physics of the Earth and Planetary Interiors, 2011, vol. 188, p. 127

Lenardic A., Crowley J. W., On the notion of well-defined tectonic regimes for terrestrial planets in this solar system and others, The Astrophysical Journal, 2012, vol. 755, p. 132

Lenton T. M., Land and ocean carbon cycle feedback effects on global warming in a simple Earth system model, Tellus B: Chemical and Physical Meteorology, 200, vol. 52, p. 1159

Lenton T. M., von Bloh W., Biotic feedback extends the life span of the biosphere, Geophysical research letters, 2001, vol. 28, p. 1715

Levenson B. P., Planet temperatures with surface cooling parameterized, Advances in Space Research, 2011, vol. 47, p. 2044

Levison H. F., Agnor C., The role of giant planets in terrestrial planet formation, The Astronomical Journal, 2003, vol. 125, p. 2692

Li K.-F., Pahlevan K., Kirschvink J. L., Yung Y. L., Atmospheric pressure as a natural climate regulator for a terrestrial planet with a biosphere, Proceedings of the National Academy of Sciences, 2009, vol. 106, p. 9576

Li W., Leaman J., Chornock R., Filippenko A. V., Poznanski D., Ganeshalingam M., Wang X., Modjaz M., Jha S., Foley R. J., et al., Nearby supernova rates from the Lick Observatory Supernova Search-II. The observed luminosity functions and fractions of supernovae in a complete sample, Monthly Notices of the Royal Astronomical Society, 2011, vol. 412, p. 1441

Lin D. N., Bodenheimer P., Richardson D. C., Orbital migration of the planetary companion of 51 Pegasi to its present location, Nature, 1996, vol. 380

Lineweaver C. H., An estimate of the age distribution of terrestrial planets in the universe: quantifying metallicity as a selection effect, Icarus, 2001, vol. 151, p. 307 
Lineweaver C. H., Fenner Y., Gibson B. K., The galactic habitable zone and the age distribution of complex life in the Milky Way, Science, 2004, vol. 303, p. 59

Liu G., An investigation of UV disinfection performance under the influence of turbidity \& particulates for drinking water applications, University of Waterloo, 2005, Dissertação de Mestrado

Liu L.-G., Water in the terrestrial planets and the moon, Icarus, 1988, vol. 74, p. 98

Lovelock J. E., Margulis L., Atmospheric homeostasis by and for the biosphere: the Gaia hypothesis, Tellus, 1974, vol. 26, p. 2

Lovelock J. E., Whitfield M., Life span of the biosphere, Nature, 1982, vol. 296, p. 561

Maberly S. C., Exogenous sources of inorganic carbon for photosynthesis by marine macroalgae 1, Journal of Phycology, 1990, vol. 26, p. 439

McCrea W., Solar System as space-probe, The Observatory, 1975, vol. 95, p. 239

McGovern P. J., Schubert G., Thermal evolution of the Earth: effects of volatile exchange between atmosphere and interior, Earth and planetary science letters, 1989, vol. 96, p. 27

Maciel W. J., Costa R. D., Metallicity gradients in the Milky Way, Proceedings of the International Astronomical Union, 2009, vol. 5, p. 317

McKay C. P., Lorenz R. D., Lunine J. I., Analytic solutions for the antigreenhouse effect: Titan and the early Earth, Icarus, 1999, vol. 137, p. 56

McKay C. P., Pollack J. B., Courtin R., The greenhouse and antigreenhouse effects on Titan, Science, 1991, vol. 253, p. 1118

McKenzie D., Bickle M., The volume and composition of melt generated by extension of the lithosphere, Journal of petrology, 1988, vol. 29, p. 625

McMahon S., O’Malley-James J., Parnell J., Circumstellar habitable zones for deep terrestrial biospheres, Planetary and space science, 2013, vol. 85, p. 312

Mandell A. M., Raymond S. N., Sigurdsson S., Formation of Earth-like planets during and after giant planet migration, The Astrophysical Journal, 2007, vol. 660, p. 823 
Marcy G., Butler R. P., Fischer D., Vogt S., Wright J. T., Tinney C. G., Jones H. R., Observed properties of exoplanets: masses, orbits, and metallicities, Progress of Theoretical Physics Supplement, 2005, vol. 158, p. 24

Marochnik L., Mukhin L., , 1988 in , Bioastronomy-The Next Steps. Springer pp 49-59

Matteucci F., The chemical evolution of the Galaxy. vol. 253, Springer Science \& Business Media, 2003

Matteucci F., François P., Galactic chemical evolution: abundance gradients of individual elements, Monthly Notices of the Royal Astronomical Society, 1989, vol. 239, p. 885

Mello F. d. S., Friaça A. C., The end of life on Earth is not the end of the world: converging to an estimate of life span of the biosphere?, International Journal of Astrobiology, 2019

Melott A. L., Lieberman B. S., Laird C. M., Martin L. D., Medvedev M. V., Thomas B. C., Cannizzo J., Gehrels N., Jackman C., Did a gamma-ray burst initiate the late Ordovician mass extinction?, International Journal of Astrobiology, 2004, vol. 3, p. 55

Melott A. L., Thomas B. C., Hogan D. P., Ejzak L. M., Jackman C. H., Climatic and biogeochemical effects of a galactic gamma ray burst, Geophysical research letters, 2005, vol. 32

Mian Z., Tozer D., No water, no plate tectonics: convective heat transfer and the planetary surfaces of Venus and Earth, Terra Nova, 1990, vol. 2, p. 455

Miller G. E., Scalo J. M., The initial mass function and stellar birthrate in the solar neighborhood, The Astrophysical Journal Supplement Series, 1979, vol. 41, p. 513

Monnereau M., Calvet M., Margerin L., Souriau A., Lopsided growth of Earth's inner core, Science, 2010, vol. 328, p. 1014

Mora C. I., Driese S. G., Colarusso L. A., Middle to late Paleozoic atmospheric $\mathrm{CO}_{2}$ levels from soil carbonate and organic matter, Science, 1996, vol. 271, p. 1105

Morrison I. S., Gowanlock M. G., Extending galactic habitable zone modeling to include the emergence of intelligent life, Astrobiology, 2015, vol. 15, p. 683 
Mortier A., Santos N., Sousa S., Israelian G., Mayor M., Udry S., On the functional form of the metallicity-giant planet correlation, Astronomy \& Astrophysics, 2013, vol. 551, p. A112

Mulders G. D., Ciesla F. J., Min M., Pascucci I., The snow line in viscous disks around low-mass stars: implications for water delivery to terrestrial planets in the habitable zone, The Astrophysical Journal, 2015, vol. 807, p. 1

Nimmo F., Why does Venus lack a magnetic field?, Geology, 2002, vol. 30, p. 987

Nisbet E. G., Nisbet R. E. R., Methane, oxygen, photosynthesis, rubisco and the regulation of the air through time, Philosophical Transactions of the Royal Society B: Biological Sciences, 2008, vol. 363, p. 2745

Noffke N., Christian D., Wacey D., Hazen R. M., Microbially induced sedimentary structures recording an ancient ecosystem in the ca. 3.48 billion-year-old Dresser Formation, Pilbara, Western Australia, Astrobiology, 2013, vol. 13, p. 1103

Ohmoto H., Watanabe Y., Kumazawa K., Evidence from massive siderite beds for a CO 2-rich atmosphere before 1.8 billion years ago, Nature, 2004, vol. 429, p. 395

Ohta K., Kuwayama Y., Hirose K., Shimizu K., Ohishi Y., Experimental determination of the electrical resistivity of iron at Earth's core conditions, Nature, 2016, vol. 534, p. 95

Ohtomo Y., Kakegawa T., Ishida A., Nagase T., Rosing M. T., Evidence for biogenic graphite in early Archaean Isua metasedimentary rocks, Nature Geoscience, 2014, vol. 7, p. 25

Oishi M., Kamaya H., A simple evolutional model of Habitable Zone around host stars with various mass and low metallicity, Astrophysics and Space Science, 2016, vol. 361, p. 66

Olson S. L., Reinhard C. T., Lyons T. W., Limited role for methane in the mid-Proterozoic greenhouse, Proceedings of the National Academy of Sciences, 2016, vol. 113, p. 11447

O’Malley-James J., Raven J., Cockell C., Greaves J., Life and light: exotic photosynthesis in binary and multiple-star systems, Astrobiology, 2012, vol. 12, p. 115 
O’Malley-James J. T., Greaves J. S., Raven J. A., Cockell C. S., Swansong biospheres: refuges for life and novel microbial biospheres on terrestrial planets near the end of their habitable lifetimes, International Journal of Astrobiology, 2013, vol. 12, p. 99

O’Neill C., Jellinek A., Lenardic A., Conditions for the onset of plate tectonics on terrestrial planets and moons, Earth and Planetary Science Letters, 2007, vol. 261, p. 20

Pavlov A. A., Hurtgen M. T., Kasting J. F., Arthur M. A., Methane-rich Proterozoic atmosphere?, Geology, 2003, vol. 31, p. 87

Pavlov A. A., Kasting J. F., Brown L. L., Rages K. A., Freedman R., Greenhouse warming by $\mathrm{CH} 4$ in the atmosphere of early Earth, Journal of Geophysical Research: Planets, 2000, vol. 105, p. 11981

Penz T., Erkaev N., Kulikov Y. N., Langmayr D., Lammer H., Micela G., Cecchi-Pestellini C., Biernat H., Selsis F., Barge P., et al., Mass loss from "Hot Jupiters"-Implications for CoRoT discoveries, Part II: Long time thermal atmospheric evaporation modeling, Planetary and Space Science, 2008, vol. 56, p. 1260

Penz T., Micela G., X-ray induced mass loss effects on exoplanets orbiting dM stars, Astronomy \& Astrophysics, 2008, vol. 479, p. 579

Penz T., Micela G., Lammer H., Influence of the evolving stellar X-ray luminosity distribution on exoplanetary mass loss, Astronomy \& Astrophysics, 2008, vol. 477, p. 309

Pierrehumbert R. T., Principles of planetary climate. Cambridge University Press, 2010

Pope E. C., Bird D. K., Rosing M. T., Isotope composition and volume of Earth's early oceans, Proceedings of the National Academy of Sciences, 2012, vol. 109, p. 4371

Prantzos N., , 2008 in , Strategies of Life Detection. Springer pp 313-322

Raghavan D., McAlister H. A., Henry T. J., Latham D. W., Marcy G. W., Mason B. D., Gies D. R., White R. J., Theo A., A survey of stellar families: multiplicity of solar-type stars, The Astrophysical Journal Supplement Series, 2010, vol. 190, p. 1

Ramirez R. M., Kaltenegger L., A volcanic hydrogen habitable zone, The Astrophysical Journal Letters, 2017, vol. 837, p. L4 
Rasool S. I., de Bergh C., The runaway greenhouse and the accumulation of $\mathrm{CO}_{2}$ in the Venus atmosphere, Nature, 1970, vol. 226, p. 1037

Rautio M., Tartarotti B., UV radiation and freshwater zooplankton: damage, protection and recovery, Freshwater reviews: a journal of the Freshwater Biological Association, 2010, vol. 3, p. 105

Raymond S. N., The search for other Earths: limits on the giant planet orbits that allow habitable terrestrial planets to form, The Astrophysical Journal Letters, 2006, vol. 643, p. L131

Raymond S. N., Mandell A. M., Sigurdsson S., Exotic Earths: Forming habitable worlds with giant planet migration, Science, 2006, vol. 313, p. 1413

Raymond S. N., Quinn T., Lunine J. I., Making other earths: dynamical simulations of terrestrial planet formation and water delivery, Icarus, 2004, vol. 168, p. 1

Raymond S. N., Quinn T., Lunine J. I., The formation and habitability of terrestrial planets in the presence of close-in giant planets, Icarus, 2005, vol. 177, p. 256

Raymond S. N., Scalo J., Meadows V. S., A decreased probability of habitable planet formation around low-mass stars, The Astrophysical Journal, 2007, vol. 669, p. 606

Renzini A., Buzzoni A., , 1986 in , Spectral evolution of galaxies. Springer pp 195-235

Ribas I., Guinan E. F., Güdel M., Audard M., Evolution of the solar activity over time and effects on planetary atmospheres. I. High-energy irradiances (1-1700 ̊), The Astrophysical Journal, 2005, vol. 622, p. 680

Richter F. M., Regionalized models for the thermal evolution of the Earth, Earth and planetary science letters, 1984, vol. 68, p. 471

Robert F., Chaussidon M., A palaeotemperature curve for the Precambrian oceans based on silicon isotopes in cherts, Nature, 2006, vol. 443, p. 969

Rocha-Pinto H. J., Maciel W. J., The metallicity distribution of G dwarfs in the solar neighbourhood, Monthly Notices of the Royal Astronomical Society, 1996, vol. 279, p. 447 
Rondanelli R., Lindzen R., Comment on"Clouds and the Faint Young Sun Paradox"by Goldblatt and Zahnle (2011), Climate of the Past, 2012, vol. 8, p. 701

Rosing M. T., Bird D. K., Sleep N. H., Bjerrum C. J., No climate paradox under the faint early Sun, Nature, 2010, vol. 464, p. 744

Rowley D. B., Rate of plate creation and destruction: 180 Ma to present, Geological Society of America Bulletin, 2002, vol. 114, p. 927

Rushby A. J., Claire M. W., Osborn H., Watson A. J., Habitable zone lifetimes of exoplanets around main sequence stars, Astrobiology, 2013, vol. 13, p. 833

Rye R., Kuo P. H., Holland H. D., Atmospheric carbon dioxide concentrations before 2.2 billion years ago, Nature, 1995, vol. 378, p. 603

Sagan C., Mullen G., Earth and Mars: Evolution of atmospheres and surface temperatures, Science, 1972, vol. 177 , p. 52

Sage R. F., The evolution of C4 photosynthesis, New phytologist, 2004, vol. 161, p. 341

Salpeter E. E., The luminosity function and stellar evolution., The Astrophysical Journal, 1955, vol. 121 , p. 161

Sandu C., Lenardic A., McGovern P., The effects of deep water cycling on planetary thermal evolution, Journal of Geophysical Research: Solid Earth, 2011, vol. 116

Santos N. C., Israelian G., Mayor M., Spectroscopic [Fe/H] for 98 extra-solar planet-host stars-Exploring the probability of planet formation, Astronomy \& Astrophysics, 2004, vol. 415 , p. 1153

Schaefer L., Sasselov D., The persistence of oceans on earth-like planets: insights from the deep-water cycle, The Astrophysical Journal, 2015, vol. 801, p. 40

Schröder K.-P., Connon Smith R., Distant future of the Sun and Earth revisited, Monthly Notices of the Royal Astronomical Society, 2008, vol. 386, p. 155

Schubert G., Stevenson D., Cassen P., Whole planet cooling and the radiogenic heat source contents of the Earth and Moon, Journal of Geophysical Research: Solid Earth, 1980, vol. 85 , p. 2531 
Schwartzman D., Life, temperature, and the Earth: the self-organizing biosphere. Columbia University Press, 2002

Schwartzman D. W., Volk T., Biotic enhancement of weathering and the habitability of Earth, Nature, 1989, vol. 340, p. 457

Selsis F., Kasting J. F., Levrard B., Paillet J., Ribas I., Delfosse X., Habitable planets around the star Gliese 581?, Astronomy \& Astrophysics, 2007, vol. 476, p. 1373

Sheldon N. D., Precambrian paleosols and atmospheric $\mathrm{CO}_{2}$ levels, Precambrian Research, 2006, vol. 147 , p. 148

Sleep N. H., Hessler A. M., Weathering of quartz as an Archean climatic indicator, Earth and Planetary Science Letters, 2006, vol. 241, p. 594

Sleep N. H., Zahnle K., Carbon dioxide cycling and implications for climate on ancient Earth, Journal of Geophysical Research: Planets, 2001, vol. 106, p. 1373

Smirnov A. V., Tarduno J. A., Evans D. A., Evolving core conditions ca. 2 billion years ago detected by paleosecular variation, Physics of the Earth and Planetary Interiors, 2011, vol. 187 , p. 225

Smyth J. R., A crystallographic model for hydrous wadsleyite $\left(\beta-\mathrm{Mg}_{2} \mathrm{SiO}_{4}\right)$ : an ocean in the Earth's interior?, American Mineralogist, 1994, vol. 79, p. 1021

Sommer R., Pribil W., Appelt S., Gehringer P., Eschweiler H., Leth H., Cabaj A., Haider T., Inactivation of bacteriophages in water by means of non-ionizing (UV-253.7 nm) and ionizing (gamma) radiation: a comparative approach, Water Research, 2001, vol. 35, p. 3109

Sotin C., Grasset O., Mocquet A., Mass-radius curve for extrasolar Earth-like planets and ocean planets, Icarus, 2007, vol. 191, p. 337

Sozzetti A., Torres G., Latham D. W., Stefanik R. P., Korzennik S. G., Boss A. P., Carney B. W., Laird J. B., A Keck HIRES doppler search for planets orbiting metal-poor dwarfs. II. On the frequency of giant planets in the metal-poor regime, The Astrophysical Journal, 2009, vol. 697, p. 544 
Stacey F. D., Cooling of the Earth-A constraint on Paleotectonic Hypotheses, Evolution of the Earth, 1981, vol. 5, p. 272

Stacey F. D., Stacey C. H., Gravitational energy of core evolution: implications for thermal history and geodynamo power, Physics of the earth and planetary interiors, 1999, vol. 110 , p. 83

Stadelmann A., Vogt J., Glassmeier K.-H., Kallenrode M.-B., Voigt G.-H., Cosmic ray and solar energetic particle flux in paleomagnetospheres, Earth, planets and space, 2010, vol. 62 , p. 333

Stapledon W. O., Star Maker 1st edn. Methuen, 1937

Sundin M., The galactic habitable zone in barred galaxies, International Journal of Astrobiology, 2006, vol. 5, p. 325

Svechnikov M., Taidakova T., The Mass Spectrum Relation for Main-Sequence Stars, Soviet Astronomy, 1984, vol. 28, p. 84

Svensmark H., Evidence of nearby supernovae affecting life on Earth, Monthly notices of the royal astronomical society, 2012, vol. 423, p. 1234

Tajika E., Faint young Sun and the carbon cycle: implication for the Proterozoic global glaciations, Earth and Planetary Science Letters, 2003, vol. 214, p. 443

Tarduno J. A., Cottrell R. D., Watkeys M. K., Hofmann A., Doubrovine P. V., Mamajek E. E., Liu D., Sibeck D. G., Neukirch L. P., Usui Y., Geodynamo, solar wind, and magnetopause 3.4 to 3.45 billion years ago, science, 2010, vol. 327, p. 1238

Tian F., Ida S., Water contents of Earth-mass planets around M dwarfs, Nature Geoscience, 2015, vol. 8, p. 177

Tikoo S. M., Elkins-Tanton L. T., The fate of water within Earth and super-Earths and implications for plate tectonics, Philosophical Transactions of the Royal Society A: Mathematical, Physical and Engineering Sciences, 2017, vol. 375, p. 20150394

Tung H., Bramall N., Price P., Microbial origin of excess methane in glacial ice and implications for life on Mars, Proceedings of the National Academy of Sciences, 2005, vol. 102, p. 18292 
Turcotte D., Schubert G., Geodynamics. Cambridge university press, 2014

Valencia D., O'connell R. J., Sasselov D. D., Inevitability of plate tectonics on super-Earths, The Astrophysical Journal Letters, 2007, vol. 670, p. L45

van den Bergh S., The supernova rate in the solar neighborhood, The Astronomical Journal, 1990, vol. 99 , p. 843

van der Lee S., Regenauer-Lieb K., Yuen D. A., The role of water in connecting past and future episodes of subduction, Earth and Planetary Science Letters, 2008, vol. 273, p. 15

van der Marel R. P., Fardal M. A., Sohn S. T., Patel E., Besla G., del Pino-Molina A., Sahlmann J., Watkins L. L., First Gaia Dynamics of the Andromeda System: DR2 Proper Motions, Orbits, and Rotation of M31 and M33, The Astrophysical Journal, 2019, vol. 872 , p. 14

Van Heck H., Tackley P., Plate tectonics on super-Earths: Equally or more likely than on Earth, Earth and Planetary Science Letters, 2011, vol. 310, p. 252

Vantrepotte V., Mélin F., , 2006 UV penetration in the water column. Institute for Environment and Sustainability

Vladilo G., Murante G., Silva L., Provenzale A., Ferri G., Ragazzini G., The habitable zone of Earth-like planets with different levels of atmospheric pressure, The Astrophysical Journal, 2013, vol. 767 , p. 65

Volk T., , 1987 in , America Journal of Science. America Journal of Science pp 763-779

von Paris P., Rauer H., Grenfell J. L., Patzer B., Hedelt P., Stracke B., Trautmann T., Schreier F., Warming the early Earth - $\mathrm{CO}_{2}$ reconsidered, Planetary and Space Science, 2008, vol. 56, p. 1244

Walker J. C., Hays P., Kasting J. F., A negative feedback mechanism for the long-term stabilization of Earth's surface temperature, Journal of Geophysical Research: Oceans, 1981, vol. 86, p. 9776

Wang J., Fischer D. A., Revealing a universal planet-metallicity correlation for planets of different sizes around solar-type stars, The Astronomical Journal, 2015, vol. 149, p. 14 
Watson A. J., Donahue T. M., Walker J. C., The dynamics of a rapidly escaping atmosphere: applications to the evolution of Earth and Venus, Icarus, 1981, vol. 48, p. 150

Watson A. J., Lovelock J. E., Biological homeostasis of the global environment: the parable of Daisyworld, Tellus B: Chemical and Physical Meteorology, 1983, vol. 35, p. 284

Weiss L. M., Marcy G. W., Petigura E. A., Fulton B. J., Howard A. W., Winn J. N., Isaacson H. T., Morton T. D., Hirsch L. A., Sinukoff E. J., et al., The California-Kepler survey. V. Peas in a pod: planets in a Kepler multi-planet system are similar in size and regularly spaced, The Astronomical Journal, 2018, vol. 155, p. 48

West A. J., Galy A., Bickle M., Tectonic and climatic controls on silicate weathering, Earth and Planetary Science Letters, 2005, vol. 235, p. 211

Wetherill G. W., , 1994 in , Planetary Systems: Formation, Evolution, and Detection. Springer pp 23-32

Whitmire D., Reynolds R., Kasting J., , 1991 in Heidmann J., Klein M., eds, , Bioastronomy The Search for Extraterrestial Life - The Exploration Broadens. Springer pp $173-178$

Whitmire D. P., Matese J. J., Criswell L., Mikkola S., Habitable planet formation in binary star systems, Icarus, 1998, vol. 132, p. 196

Wilde S. A., Valley J. W., Peck W. H., Graham C. M., Evidence from detrital zircons for the existence of continental crust and oceans on the Earth 4.4 Gyr ago, Nature, 2001, vol. 409, p. 175

Wilhelm S. W., Jeffrey W. H., Suttle C. A., Mitchell D. L., Estimation of Biologically Damaging UV Levels in Marine Surface Waters with DNA and Viral Dosimeters $\llbracket$, Photochemistry and Photobiology, 2002, vol. 76, p. 268

Williams D. M., Kasting J. F., Habitable planets with high obliquities, Icarus, 1997, vol. 129 , p. 254

Williams G. E., Geological constraints on the Precambrian history of Earth's rotation and the Moon's orbit, Reviews of Geophysics, 2000, vol. 38, p. 37 
Wolf E., Toon O., Delayed onset of runaway and moist greenhouse climates for Earth, Geophysical Research Letters, 2014, vol. 41, p. 167

Wolf E. T., Shields A. L., Kopparapu R. K., Haqq-Misra J., Toon O. B., Constraints on climate and habitability for earth-like exoplanets determined from a general circulation model, The Astrophysical Journal, 2017, vol. 837, p. 107

Wordsworth R. D., Pierrehumbert R. T., Water loss from terrestrial planets with $\mathrm{CO}_{2}$-rich atmospheres, The Astrophysical Journal, 2013, vol. 778, p. 154

Youdin A. N., The exoplanet census: A general method applied to Kepler, The Astrophysical Journal, 2011, vol. 742, p. 38

Young G. M., Precambrian supercontinents, glaciations, atmospheric oxygenation, metazoan evolution and an impact that may have changed the second half of Earth history, Geoscience Frontiers, 2013, vol. 4, p. 247

Zahnle K. J., Catling D. C., The cosmic shoreline: The evidence that escape determines which planets have atmospheres, and what this may mean for Proxima Centauri B, The Astrophysical Journal, 2017, vol. 843, p. 122

Zeikus J., Winfrey M., Temperature limitation of methanogenesis in aquatic sediments., Appl. Environ. Microbiol., 1976, vol. 31, p. 99

Zenoff V. F., Siñeriz F., Farias M. E., Diverse responses to UV-B radiation and repair mechanisms of bacteria isolated from high-altitude aquatic environments, Appl. Environ. Microbiol., 2006, vol. 72, p. 7857

Zhu W., Petrovich C., Wu Y., Dong S., Xie J., About 30\% of Sun-like Stars Have Keplerlike Planetary Systems: A Study of Their Intrinsic Architecture, The Astrophysical Journal, 2018, vol. 860, p. 101

Zhu W., Wang J., Huang C., Dependence of small planet frequency on stellar metallicity hidden by their prevalence, The Astrophysical Journal, 2016, vol. 832, p. 196

Zinder S., Anguish T., Cardwell S., Effects of temperature on methanogenesis in a thermophilic (58 C) anaerobic digestor, Appl. Environ. Microbiol., 1984, vol. 47, p. 808 
Zsom A., Seager S., De Wit J., Stamenković V., Toward the minimum inner edge distance of the habitable zone, The Astrophysical Journal, 2013, vol. 778, p. 109

Zuluaga J. I., Bustamante S., Cuartas P. A., Hoyos J. H., The influence of thermal evolution in the magnetic protection of terrestrial planets, The Astrophysical Journal, 2013a, vol. 770 , p. 23

Zuluaga J. I., Bustamante S., Cuartas P. A., Hoyos J. H., The influence of thermal evolution in the magnetic protection of terrestrial planets, The Astrophysical Journal, 2013b, vol. 770 , p. 23

Zuluaga J. I., Cuartas P. A., The role of rotation in the evolution of dynamo-generated magnetic fields in Super Earths, Icarus, 2012, vol. 217, p. 88 
Apêndice 



\section{Apêndice A}

\section{Ajustes do Albedo Planetário}

\section{A.1 Albedo Planetário para o Sistema Solar}

Partindo da parametrizações de Williams e Kasting (1997) temos o albedo planetário no Sistema Solar, $A_{p}$, em função da temperatura superficial, $T_{s}$, da pressão parcial de $\mathrm{CO}_{2}, P_{\mathrm{CO}_{2}}$, do albedo superficial, $a_{s}$, e do cosseno do ângulo zenital, $\cos (Z)=\mu$. $Z$ foi mantido constante em $60^{\circ}$. O intervalo de aplicabilidade com confiança é: $0<a_{s}<1$, $190<T_{s}<360 \mathrm{~K}$ (mas é bem comportada para além desse intervalo, podendo ser utilizada até $\sim 460 \mathrm{~K}), 0<\mu<1$ e $10^{-5}<P_{\mathrm{CO}_{2}}<10$ bar.

$$
A_{p}=A_{p, a} \times \text { Sigmoide }_{1}+A_{p, b} \times \text { Sigmoide }_{2}
$$

$$
\text { Sigmoide }_{1}=\frac{1}{1+\exp \left[-0,15\left(T_{s}-280 K\right)\right]}
$$

Sigmoide $_{2}=1-$ Sigmoide $_{1}$

$$
\begin{aligned}
& A_{p, a}= \\
& -6,8910 \times 10^{-1}+1,0460 a_{s}+7,8054 \times 10^{-3} T_{s}-2,8373 \times 10^{-3} P_{C O_{2}}-2,8899 \times 10^{-1} \mu \\
& -3,7412 \times 10^{-2} a_{s} P_{C O_{2}}-6,3499 \times 10^{-3} \mu P_{C O_{2}}+2,0122 \times{ }^{-1} a_{s} \mu \\
& -1,8508 \times 10^{-3} a_{s} T_{s}+1,3649 \times 10^{-4} \mu T_{s}+9,8581 \times 10^{-5} P_{C O_{2}} T_{s} \\
& +7,3239 \times 10^{-2} a_{s}{ }^{2}-1,6555 \times 10^{-5} T_{s}{ }^{2}+6,5817 \times 10^{-4} P_{C O_{2}}{ }^{2}+8,1218 \times 10^{-2} \mu^{2}
\end{aligned}
$$




$$
\begin{aligned}
& A_{p, b}= \\
& 1,1082+1,5172 a_{s}-5,7993 \times 10^{-3} T_{s}+1,9705 \times 10^{-2} P_{C O_{2}}-1,8670 \times 10^{-1} \mu \\
& -3,1355 \times 10^{-2} a_{s} P_{C O_{2}}-1,0214 \times 10^{-2} \mu P_{C O_{2}}+2,0986 \times{ }^{-1} a_{s} \mu \\
& -3,7098 \times 10^{-3} a_{s} T_{s}+1,1335 \times 10^{-4} \mu T_{s}+5,3714 \times 10^{-5} P_{C O_{2}} T_{s} \\
& +7,5887 \times 10^{-2} a_{s}{ }^{2}+9,2690 \times 10^{-4} T_{s}{ }^{2}-4,1327 \times 10^{-4} P_{C O_{2}}{ }^{2}+6,3298 \times 10^{-2} \mu^{2}
\end{aligned}
$$

Para além de $460 \mathrm{~K}$ usamos o albedo planetário de Kasting et al. (1993):

$$
A_{p}=7,0214 \times 10^{-9} \times T_{s}^{3}-1,38243 \times 10^{-5} \times T_{s}^{2} 9,11186 \times 10^{-3} \times T_{s}-1,65242
$$

\section{A.2 Albedo Planetário para Outras Estrelas}

Partindo dos resultados e parametrizações de Kasting et al. (1993) e de Williams e Kasting (1997) fizemos ajustes para parametrizar o albedo planetário, $A_{p}$, para outras estrelas em função da temperatura superficial, $T_{s}$, da pressão parcial de $\mathrm{CO}_{2}, P_{\mathrm{CO}_{2}}$, do albedo superficial, $a_{s}$, e da massa estelar, $M^{*}$. $Z$ foi mantido constante em $60^{\circ}$ e incorporado nas constantes.

$$
\begin{gathered}
A_{p}=A_{T}+A_{\mathrm{CO}_{2}}+A_{\text {cor }} \\
A_{\text {cor }}=a_{1} \exp \left[-\frac{\left(T_{s}-b_{1}\right)^{2}}{2 c_{1}^{2}}\right] \\
a_{1}=a_{2}+b_{2} a_{s} \\
a_{2}=-0,386765+0,0169296 \times P_{C O 2}+\frac{0,39733}{1,61986+P_{C O 2}} \\
b_{2}=0,812673-0,037412 \times P_{C O 2}
\end{gathered}
$$




$$
\begin{aligned}
& \text { Para } T_{s} \leqslant 460 \mathrm{~K} \\
& A_{T}=a_{3}+b_{3} T_{s}+c_{3} T_{s}^{2}+d_{3} T_{s}^{3}+e_{3} T_{s}^{4}+f_{3} T_{s}^{5} \\
& a_{3}=-1,01957 \times 10^{1}+1,43174 \times 10^{1} M^{*}-7,96964 \times M^{* 2} \\
& b_{3}=1,62823 \times 10^{-1}-2,40371 \times 10^{-1} M^{*}+1,32268 \times 10^{-1} M^{* 2} \\
& c_{3}=-9,81783 \times 10^{-4}+1,56150 \times 10^{-3} M^{*}-8,44508 \times 10^{-4} M^{* 2} \\
& d_{3}=2,86299 \times 10^{-6}-4,91160 \times 10^{-6} M^{*}+2,60927 \times 10^{-6} M^{* 2} \\
& e_{3}=-4,08310 \times 10^{-9}+7,50810 \times 10^{-9} M^{*}-3,90550 \times 10^{-9} M^{* 2} \\
& f_{3}=2,28660 \times 10^{-12}-4,46064 \times 10^{-12} M^{*}+2,26858 \times 10^{-12} M^{* 2}
\end{aligned}
$$

Para $460 \mathrm{~K}<T_{s} \leqslant 650 \mathrm{~K}$

$$
\begin{aligned}
& A_{T}=a_{4}+b_{4} T_{s}+c_{4} T_{s}^{2}+d_{4} T_{s}^{3} \\
& a_{4}=3,75418 \times 10^{-2}-2,12608 \times 10^{0} M^{*}+4,36116 \times 10^{-1} M^{* 2} \\
& b_{4}=-1,84673 \times 10^{-4}+1,05972 \times 10^{-2} M^{*}-1,30067 \times 10^{-3} M^{* 2} \\
& c_{4}=-5,11128 \times 10^{-7}-1,39831 \times 10^{-5} M^{*}+6,69944 \times 10^{-7} M^{* 2} \\
& d_{4}=6,46649 \times 10^{-10}+6,08241 \times 10^{-9} M^{*}+2,92339 \times 10^{-10} M^{* 2}
\end{aligned}
$$

$b_{5}=2,77307 \times 10^{-4}-9,48289 \times 10^{-4} M^{*}+2,83289 \times 10^{-5} \times M^{* 2}$

$c_{5}=1,20641-1,04977 \times M^{*}+2,90365 \times 10^{-01} \times M^{* 2}$ 